\title{
Site $\mathrm{U} 1305^{1}$
}

\author{
Expedition 303 Scientists $^{2}$
}

\section{Chapter contents}

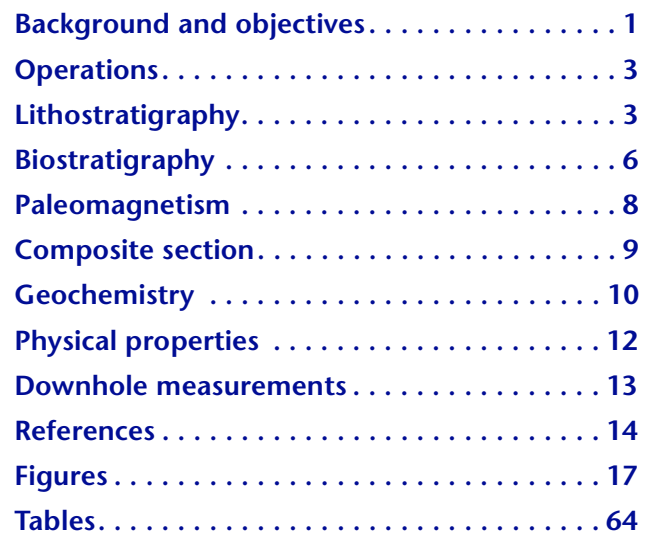

${ }^{1}$ Expedition 303 Scientists, 2006. Site U1305. In Channell, J.E.T., Kanamatsu, T., Sato, T., Stein, R., Alvarez Zarikian, C.A., Malone, M.J., and the Expedition 303/306 Scientists. Proc. IODP, 303/ 306: College Station TX (Integrated Ocean Drilling Program Management International, Inc.). doi:10.2204/iodp.proc.303306.105.2006 'Expedition 303 Scientists' addresses.

\section{Background and objectives}

The Labrador Sea has been a conduit for meltwater from the Laurentide, Inuitian, and Greenland Ice Sheets into the North Atlantic Ocean. Labrador Sea sediments, therefore, provide valuable insights into ice sheet variability (Hesse and Chough, 1980; Hillaire-Marcel et al., 1994; Stoner et al., 1995b, 1996; Hiscott et al., 2001) and the response of thermohaline circulation to freshwater pulses (Hillaire-Marcel and Bilodeau, 2000). The Eirik Drift (Fig. F1) was built in the Pliocene and Quaternary by sediment deposition as deepwater currents from the Denmark Strait transporting Norwegian Sea Overflow Water were diverted around southern Greenland (see Arthur et al., 1989). The sediment pile hence provides a high-resolution archive for monitoring this component of North Atlantic Deep Water (NADW) as it enters the Labrador Sea.

Integrated Ocean Drilling Program Site U1305 is located off southern Greenland at the southwestern extremity of the Eirik Drift (Fig. F1). The site is $82.2 \mathrm{~km}$ south of Ocean Drilling Program (ODP) Site 646 (Fig. F2) and in the same water depth (3459 $\mathrm{m}$ ). Two holes were drilled at Site 646 during ODP Leg 105 (August-October, 1985) in poor weather conditions (Shipboard Scientific Party, 1987). The depths of the drilled intervals were 103.5 meters below seafloor (mbsf) in Hole 646A and 777 mbsf in Hole 646B. At this site, the sediments comprise silty clays in the Upper Pliocene-Quaternary (0-188 mbsf), muddy sand and silty muds in part of the Upper Pliocene (188-236 mbsf), and silty clay in the upper Miocene-Upper Pliocene interval (236-766 mbsf). The Site 646 sediments carry a well-defined magnetization component resolved by alternating-field (AF) demagnetization. The Brunhes/ Matuyama boundary was identified at 60 mbsf (Clement et al., 1989), indicating a mean Brunhes sedimentation rate of $7.7 \mathrm{~cm} /$ k.y. Magnetostratigraphy of the upper Miocene-Holocene record was compromised by incomplete recovery and core disturbance, which was exacerbated by poor weather conditions during drilling. Planktonic oxygen isotope data (Aksu et al., 1989) are available from Site 646 sediments to marine isotope Stage (MIS) 23 ( 900 ka).

The Eirik Drift was built largely after the mid-Early Pliocene, and at Site 646, a prominent seismic Reflector R1 that correlates to the middle of the Upper Pliocene lies at $0.28 \mathrm{~s}$ two-way traveltime ( 236 mbsf) (Arthur et al., 1989). The objectives at Site 646 were focused largely below R1; therefore, maximizing the sediment thickness above R1 was not a priority. For the purpose of generat- 
ing a high-resolution record of the uppermost Pliocene and Quaternary, we targeted a location where R1 was deepest at the desired water depth within the multichannel seismic network obtained over the Eirik Drift during Knorr Cruise KN166-14 in summer 2002. Site U1305 was placed at common depth point 900 on seismic Line 25 (Figs. F3, F4) where seismic Reflector R1 is identified at $\sim 540 \mathrm{mbsf}$ $(0.35 \mathrm{~s})$, implying a mean sedimentation rate of $\sim 18$ $\mathrm{cm} / \mathrm{k}$.y. for the uppermost Pliocene and Quaternary section at this site, approximately twice that for the same interval at Site 646 . The $3.5 \mathrm{kHz}$ data yield penetration to $\sim 50 \mathrm{mbsf}$ (Fig. F5).

The detrital layer stratigraphy within the Quaternary section at Site 646 is of particular interest because these detrital layers can be associated with instability of the Laurentide, Inuitian, and Greenland Ice Sheets. These detrital layers were described in the original studies of Site 646 sediments (Cremer, 1989; Hiscott et al., 1989); however, two piston cores collected subsequently within a few hundred meters of the Site 646 location have drawn attention to their importance. The first piston core (HU90-013-013) was collected by CCGS Hudson in 1991 in $3380 \mathrm{~m}$ water depth. A second core (MD99-2227) was collected at almost the same location in $3460 \mathrm{~m}$ water depth by the Marion-Dufresne during the 1999 Images cruise (Turon et al., 1999). In spite of evident core stretching in the upper part of Core MD99-2227, the magnetic susceptibility records from the two cores can be correlated one to another and to Site 646 (Fig. F6). A constant offset of $3.6 \mathrm{~m}$ was added to the mbsf depth of Site 646 to align the susceptibility high found at 14 mbsf in Core HU90-13-013 (Fig. F6). This feature occurs within MIS 5e in both records (Aksu et al., 1989; Hall et al., 1989; Hillaire-Marcel et al., 1994; Stoner et al., 1996). Differences in the depths of correlative features (Fig. F6) can be largely attributed to stretching in the upper part of Core MD99-2227.

Core HU90-013-013 has been studied in more detail than MD99-2227, for which published information is limited to the Images cruise report (Turon et al., 1999). Core HU90-013-013 is $1760 \mathrm{~cm}$ long and extends into MIS 7 (Hillaire-Marcel et al., 1994). Highresolution planktonic $\delta^{18} \mathrm{O}$ and acceleration mass spectrometry (AMS) ${ }^{14} \mathrm{C}$ data (Hillaire-Marcel et al., 1994) and magnetic stratigraphy based on paleointensity (Stoner et al., 1998) indicate that over the last glacial cycle sedimentation rates were $\sim 7-10 \mathrm{~cm} / \mathrm{k} . \mathrm{y}$. during glacial intervals and $>30 \mathrm{~cm} / \mathrm{k}$.y. during the Holocene.

Core HU90-013-013 preserves a composite record of NADW entering the Labrador Sea and Laurentideand Greenland-derived detrital events (Hillaire-Mar- cel et al., 1994; Stoner et al., 1998). In Core HU90013-013, susceptibility peaks and magnetic grain size proxies indicating coarsening document detrital layers associated with instability of the Greenland Ice Sheet (Stoner et al., 1995b). In the Quaternary at Site 646, carbonate-rich detrital layers are often delicately laminated, have sharp bases and bioturbated tops, and are associated with spillover turbidites from the Northwest Atlantic Mid-Ocean Channel (NAMOC) (Hesse and Chough, 1980; Chough et al., 1987) and/or detritus shedding off the Greenland margin (Hiscott et al., 1989). Other siliciclastic laminated silts and very fine sands may indicate velocity fluctuations in the contour currents that account for the silty clays that constitute the bulk of the Pliocene-Quaternary sediment pile on the Eirik Drift (Chough, 1985; Hiscott et al., 1989).

The sedimentation pattern in Core HU90-013-013, recovered in $3380 \mathrm{~m}$ water depth, contrasts with that in Core HU90-013-012, recovered in $2830 \mathrm{~m}$ water depth 108 km northeast of Core HU90-013-013 (Hillaire-Marcel et al., 1994; Stoner et al., 1998). At this shallower water depth site, deposition is expanded during glacials (>10 cm/k.y.) and condensed during interglacials. This contrasting sedimentation pattern in Core HU90-013-012 and Core HU90-013-013 is due to the position of these cores relative to the present high-speed axis of the Western Boundary Undercurrent (WBUC) (Fig. F1) (Hillaire-Marcel et al., 1994; Hillaire-Marcel and Bilodeau, 2000).

Similarly, the deeper site (Site U1305) sampled during Expedition 303 is located below the WBUC (Fig. F1) and is therefore characterized by expanded interglacial sedimentation (Hillaire-Marcel et al., 1994). The shallower water site (Site U1306), located in a water depth of $2273 \mathrm{~m}$, exhibited high sedimentation rates during glacial intervals and more condensed deposition during interglacial periods. The contrasting sedimentation patterns between Sites U1305 and U1306 will allow us to document changes in the outflow of the WBUC (therefore in the production of NADW) during Pliocene-Quaternary time and also to reconstruct the deep-sea circulation patterns that prevailed during interglacial intervals. The composite record from the two sites will benefit from the contrasting sedimentation patterns, thereby maximizing the resolution of the composite record at this location.

The objective of drilling at Site U1305 is to recover a complete uppermost Pliocene-Quaternary sedimentary section with sedimentation rates that allow high-resolution studies of the environmental history of surrounding ice sheet instability, the WBUC, and, hence, the formation of NADW and the West Greenland (surface) Current. The chosen water depth for 
Site U1305 (3459 m) is designed such that deposition occurred predominantly below the WBUC (Fig. F1), accounting for expanded interglacial intervals and relatively condensed glacial intervals. Using a paleointensity-assisted chronology (PAC), detrital layers (carbonate rich and carbonate poor) in Core HU90013-013 have been correlated to North Atlantic Heinrich-type layers in the H1-H6 interval and to episodes of Greenland deglaciation (Stoner et al., 1998). The overall objective of drilling at Site U1305 is to place the detrital layer stratigraphy into a PAC that can be exported outside the region with millennialscale precision. In so doing, we aim to reconstruct ice sheet instability as well as the isotopic characteristics of surface and deep waters.

\section{Operations}

\section{Transit from Site U1304 to Site U1305}

We departed Site U1304 at $1230 \mathrm{~h}$ on 14 October 2004. The $577 \mathrm{nmi}$ transit to Site U1305 (LAB6A) was accomplished in 2.3 days at an average speed of 10.4 kt. We arrived at the Site U1305 and were positioned on location at $2015 \mathrm{~h}$ on 16 October.

\section{Hole U1305A}

Following routine deployment of the drill string, the driller positioned the bit at 3473.4 meters below rig floor (mbrf) (8 $\mathrm{m}$ shallower than the calculated precision depth recorder depth of $3481.4 \mathrm{mbrf}$ ). Hole U1305A was initiated with the advanced piston corer (APC) at $0600 \mathrm{~h}$ on 17 October 2004. The recovery of the initial core was $8.87 \mathrm{~m}$, suggesting a seafloor depth of 3474.0 mbrf; however, correlation to previous piston cores indicated that the upper part of the sediment section had not been recovered. Piston coring advanced to a total depth of 280.0 mbsf with an average recovery of $105.2 \%$. Recovery percentages were affected by gas expansion at this site (see "Geochemistry"). Use of nonmagnetic core barrels and orientation tools are indicated in Table T1. Cores $29 \mathrm{H}$ and $30 \mathrm{H}$ were advanced by recovery, and six cores had to be obtained by drillover (Cores $20 \mathrm{H}$, $24 \mathrm{H}$, and $26 \mathrm{H}-29 \mathrm{H}$ ). Hole U1305A concluded when the bit cleared the seafloor at $1645 \mathrm{~h}$ on 17 October.

\section{Hole U1305B}

The ship was offset $30 \mathrm{~m}$ east of Hole U1305A. To obtain a mudline core and recover the uppermost part of the sedimentary section, the bit was positioned $4.5 \mathrm{~m}$ shallower than at Hole U1305A. Hole U1305B was spudded at $1945 \mathrm{~h}$ on 18 October 2004, recovering $8.25 \mathrm{~m}$, which suggested a seafloor depth of 3459.2 meters below sea level (mbsl) (3470.1 mbrf).
Piston coring advanced to a total depth of 264.8 mbsf with an average recovery of $103.6 \%$ (Table T1). A partial stroke of the APC occurred while obtaining Core $27 \mathrm{H}$, and only two core barrels had to be drilled over (Cores $25 \mathrm{H}$ and $28 \mathrm{H}$ ). Hole U1305A operations concluded when the bit cleared the seafloor at 0215 $\mathrm{h}$ on 20 October.

\section{Hole U1305C}

After offsetting $20 \mathrm{~m}$ east of Hole U1305B, Hole U1305C was spudded at $0400 \mathrm{~h}$ on 20 October 2004. Based on recovery of the first core and bit depth, the seafloor depth was calculated to be $3458.8 \mathrm{mbsl}$ (3469.7 mbrf). Piston coring advanced to a final depth of 287.1 mbsf with an average recovery of 103.9\% (Table T1). One core was obtained during a partial stroke (Core 19H), which was advanced by recovery. Four other cores were partially stroked (Cores $28 \mathrm{H}-31 \mathrm{H}$ ), as indicated by the failure of the corer to completely bleed off pressure. However, these four were not advanced by recovery because each of the core barrels were full. No core barrels required drillover in Hole U1305C.

After completing coring operations, Hole U1305C was displaced with sepiolite mud and the drill string was retracted to $95 \mathrm{mbsf}$ in preparation for logging. The triple combination (triple combo) tool string was deployed to within $\sim 29 \mathrm{~m}$ of the bottom of the hole (287 mbsf). The $163 \mathrm{~m}$ of open hole and then the interval within the pipe to the seafloor were successfully logged. The tool was lowered back to $110 \mathrm{~m}$ below the pipe for the typical short, quality control repeat pass. After completing the run through the open hole, the tool string could not be pulled into the pipe. After several unsuccessful attempts to work the tool into the pipe, the drill string was lifted, which freed the tool. After recovering the tool, it was discovered that the caliper arm was broken and the armored logging line had been damaged. Following a review of the heave conditions (up to $4 \mathrm{~m}$ ), the hole condition, tool safety, and operational constraints, it was decided to forgo the deployment of the Formation MicroScanner (FMS)-sonic tool string. After recovering the drill string and disassembling the bottom-hole assembly for transit, we departed for Site U1306 (LAB7A) at $1400 \mathrm{~h}$ on 22 October.

\section{Lithostratigraphy}

Three holes were drilled at Site U1305 (Table T1). Core recovery at Site U1305 was 104\%. All cores were recovered using the APC. The sediments at Site U1305 are dominated by varying mixtures of terrigenous components and biogenic material (primarily quartz, detrital carbonate, and nannofossils) (see 
"Site U1305 smear slides" in "Core Descriptions;" Fig. F7), so the most common lithologies are silty clay, silty clay with nannofossils, nannofossil silty clay, silty clay nannofossil ooze, and nannofossil ooze with silty clay (Fig. F8). Gradational and burrowed contacts between these lithologies are much more common than well-defined or sharp boundaries. In addition to these lithologies, we observed many intervals of silty clay with sandy silt laminae, which are designated as a distinct lithologic type, separate from silty clay. Abundances of terrigenous components, as estimated from smear slides, are quartz, $0 \%-85 \%$; detrital carbonate, $0 \%-85 \%$; feldspars, 0\%-30\%; clay minerals (including chlorite), 0\%-85\%; heavy minerals (especially hornblende), 0\%-1\%; and volcanic glass, $0 \%-5 \%$. No discrete ash layers were observed. Dropstones are present in low numbers ( 1 entity per $3 \mathrm{~m}$ of core) throughout these cores and display a wide range of compositions, including acidic intrusive and metamorphic (granites, gneisses, and granitoids), basic igneous and/or metamorphic (basalts and metabasalts), and sedimentary and metasedimentary (sandstone and limestone). Abundances of biogenic components, as estimated from smear slides, are nannofossils, $0 \%-$ $88 \%$; foraminifers, $0 \%-20 \%$; diatoms, $0 \%-20 \%$; radiolarians, 0\%-10\%; and sponge spicules, $0 \%-10 \%$. Total carbonate contents range from 1 to $49 \mathrm{wt} \%$ in these cores (see "Geochemistry;" Table T21). Pyrite (usually associated with burrows) and iron oxide coatings on grains are present occasionally, constituting the only authigenic sediment components observed.

The sediments at Site U1305 are designated as a single unit composed of Holocene-uppermost Pliocene (see "Biostratigraphy" and "Paleomagnetism") terrigenous and biogenous sediments, which are gradationally interbedded at scales of a few meters or less.

\section{Description of units}

\section{Unit I}

Intervals: Sections 303-U1305A-1H-1, $0 \mathrm{~cm}$, to 30CC, $29 \mathrm{~cm}$; 303-U1305B-1H-1, $0 \mathrm{~cm}$, to $28 \mathrm{H}-$ $\mathrm{CC}, 16 \mathrm{~cm}$; and $303-\mathrm{U} 1305 \mathrm{C}-1 \mathrm{H}-1,0 \mathrm{~cm}$, to $31 \mathrm{H}-\mathrm{CC}, 25 \mathrm{~cm}$

Depths: Hole U1305A: 0-280.0 mbsf, Hole U1302B: 0-265.3 mbsf, and Hole U1305C: 0287.9 mbsf (0-314 meters composite depth [mcd])

Age: Holocene-Late Pliocene

Unit I is composed predominantly of silty clay, silty clay with nannofossils, nannofossil silty clay, silty clay nannofossil ooze, and nannofossil ooze with silty clay. Throughout the section, numerous centimeter- to decimeter-scale intervals of sandy silt lami- nae are interbedded with silt clay. Clay, foraminifer nannofossil ooze with silty clay, silty clay with diatoms, silty clay with sponge spicules, and silty clay nannofossil ooze are present as minor lithologies. All lithologies occur as horizontally bedded, undisturbed sediments. The uppermost $10-15 \mathrm{~cm}$ in Sections 303-U1305B-1H-1 and 303-U1305C-1H-1 are reddish brown to brownish gray and are interpreted from smear slide data as surface-oxidized equivalents of the underlying lithologies (Fig. F9). In both of these cores, a zone of concentrated iron oxides is present at the base of the oxidized sediments. Dropstones are present throughout Unit I, and their distribution is plotted in Figure F10.

Bioturbation is present throughout most of this unit; the most common indicators are diffuse centimeterscale mottling and millimeter-scale pyritic burrow fills. In some cases, discrete burrows or macroscopic pyritized burrows were observed. At greater depths in all three holes, the remnants of burrows are preserved as sandy silt blebs. The bioturbation index for the silty clays ranges from absent to moderate, but most silty clays display moderate bioturbation.

Color variation within the silty clays is minor, varying between dark gray (5Y $4 / 1$ and $\mathrm{N} 4 / 1$ ) to very dark gray (5Y $3 / 1$ and N 3/1). The nannofossil lithologies, in general, are a lighter shade of gray (5Y 5/1) and tend to have moderate to common bioturbation. The sandy silt laminae occur most frequently in the silty clay intervals. Hence, the laminated intervals are predominantly dark (5Y 4/1) to very dark (5Y $3 / 1)$ gray, with lesser occurrences of gray (5Y 5/1) and olive-gray (5Y 4/2). Contacts between these lithologies generally are gradational or burrowed; the most common exceptions are the sharp contacts at the bases of the sandy silt laminae and $\mathrm{CaCO}_{3}$-rich silty clay intervals (Fig. F11). Basal contacts between these two lithologies and the underlying silty clays are sharp and commonly scoured. In contrast, the upper boundaries of these intervals (the sandy silt laminae and $\mathrm{CaCO}_{3}$-rich silty clays) are often heavily burrowed and commonly gradational (Fig. F12). Some intervals also exhibit a fining-upward trend in grain size with the basal laminae having more sandsized particles than the silt laminae above. Millimeter-scale cross lamination is observed in a majority of the sandy silt laminae (Fig. F11).

\section{Discussion}

Sediments in Unit I at Site U1305 reflect the input of biogenic and terrigenous components. These sediments represent pelagic and hemipelagic deposition modified by the interaction of deep ocean currents and bottom topography. The resulting sediment composition reflects environmental changes at the 
ocean's surface that caused variations in phytoplankton and zooplankton assemblages, aerosol inputs, and the discharge and source of icebergs. Because it is located in the lee of the Eirik Drift crest, Site U1305 accumulates sediments at high rates when bottom currents (NADW) are strong. As proposed in the Expeditions 303 and 306 Scientific Prospectus (Channel, Sato, Kanamatsu, Stein, Malone, et al., 2004), another source that might contribute sediment to Site U1305 is the transport of sediments down the NAMOC. Sediments moving through this channel may overflow the levees from time to time and spread laterally, possibly reaching Site U1305. Thus, this site is potentially well positioned to examine the relationships between the high-latitude surface ocean, cryosphere, and bottom circulation. Furthermore, the combination of records from this deep location $(3459 \mathrm{~m})$ and the shallower Site U1306 $(2271 \mathrm{~m})$ provides a unique opportunity to understand deep ocean circulation and climate variations throughout much of the Pleistocene epoch.

Large-scale patterns in the distribution of important lithologies at Site U1305 are presented in Figure F8. Of the $867 \mathrm{~m}$ of sediment recovered at this site, 757 $\mathrm{m}(87 \%)$ is silty clay and related derivatives (e.g., silty clay with nannofossils and silty clay with diatoms). Nannofossil ooze and its variations (e.g., silty clay nannofossil ooze or nannofossil ooze with silty clay) comprise $77 \mathrm{~m}$ (9\%) of the sediments, whereas sandy silt laminae are the dominant lithology in 33 $\mathrm{m}(4 \%)$ of the sediments. The most notable downhole lithologic change is the increased abundance of nannofossil ooze found between $\sim 60$ and $100 \mathrm{mcd}$, corresponding roughly to Cores $6 \mathrm{H}$ through $10 \mathrm{H}$ (or 60-100 mcd) in each hole (Fig. F8). Preliminary age estimates suggest that this interval corresponds to the ages of $\sim 300-500 \mathrm{ka}$ (see "Biostratigraphy"). Thus, the higher occurrence of nannofossil ooze may correspond to the interglacial conditions during MIS 9,11 , and 13 .

Sandy silt laminae are found throughout the recovered section in all holes and may be related to either mass-sediment transport events or intensification of bottom currents. Cross lamination is evident in many of these intervals (Fig. F11). These sandy silt laminae produce the very high peaks observed in the magnetic susceptibility records (see "Physical properties"). Similar peaks can be seen in piston and gravity cores collected from this region (Hillaire-Marcel et al., 1994), indicating that the sandy silt layers represent regional events. As such, understanding their significance should be an important focus in postcruise studies.
In addition to the sandy silt laminae, centimeter- to decimeter-scale intervals of silty clay composed largely of detrital carbonate are present in the Site U1305 sediments. These carbonate intervals are recognized easily by their olive-gray color and fine clayey texture and are observed in all holes (Table T2). Sandy silt laminae are sometimes present within these intervals, but not always. Basal contacts of the detrital carbonate layers are sharp and sometimes irregular in appearance (Fig. F12). The top boundaries are commonly bioturbated and grade into the above sediments. The nature of the contacts indicates that the detrital carbonate layers were probably deposited rapidly. Although these layers appear throughout Unit I, a distinct change in the thickness of individual layers occurs at $\sim 160$ mcd. The average thickness of detrital carbonate layers above $156 \mathrm{mcd}$ is $7 \mathrm{~cm}$, whereas the average thickness below $156 \mathrm{mcd}$ is 25 $\mathrm{cm}$. Interestingly, this change appears to occur at a level where the sediments have normal polarity assigned to the Jaramillo Subchron ( $1 \mathrm{Ma}$ ) (see "Paleomagnetism") and corresponds roughly to the time when the climatic signal transitioned from a 40 k.y. rhythm to a 100 k.y. beat.

Gravel counts, defined as the number of clasts that are $>2 \mathrm{~mm}$ in a $10 \mathrm{~cm}$ interval, were made on each section in all three holes, yielding a total of 295 clasts or $\sim 1$ clast for every $3 \mathrm{~m}$ of core (Fig. F10). Therefore, the cryospheric imprint at this site will need to be evaluated in postcruise studies using microscopic and/or other techniques.

One of the goals of Expedition 303 is to examine millennial-scale climate variability beyond the scope obtained by conventional piston coring efforts. Reconstructing climate variability on this scale requires sedimentation rates $>10 \mathrm{~cm} / \mathrm{k}$.y. The sediment record recovered at Site U1305 appears to be free of hiatuses and to have sedimentation rates sufficiently high to allow studies of millennial-scale change (see "Composite section"). One encouraging observation is that several horizons at Site U1305 have distinct textural and compositional characteristics and probably correspond to the Heinrich $(\mathrm{H})$ events. For example, layers with distinct color and rich in detrital carbonate suggest that the $\mathrm{H} 2$ and $\mathrm{H} 4$ layers are present in intervals $303-\mathrm{U} 1305 \mathrm{C}-2 \mathrm{H}-3,115-120 \mathrm{~cm}$, and $2 \mathrm{H}-4$, $57-63 \mathrm{~cm}$, respectively (Fig. F13). Knowing the position of these layers in the core allows us to identify $\mathrm{HO}$ and $\mathrm{H} 1$ layers in intervals 303-U1305C-2H-3, 32$40 \mathrm{~cm}$, and $2 \mathrm{H}-3,67-72 \mathrm{~cm}$, respectively. The $\mathrm{H} 3$ layer is more difficult to identify, but may be tentatively placed in interval 303-U1305C-2H-3, 38-140 $\mathrm{cm}$. These are preliminary assignments and are sub- 
ject to revision with postcruise studies. However, the preliminary interpretation does demonstrate that there are clear lithologic differences that apparently correspond to recognized millennial-scale climate events.

As noted previously, the magnetic susceptibility record from Site U1305 correlates well with magnetic susceptibility records for other cores from this region (e.g., Hillaire-Marcel et al., 1994), affording an opportunity to further evaluate the potential for this site to yield high-resolution climate records (Fig. F14). This correlation indicates that sediment accumulation is enhanced in the region of Site U1305 during MIS 1, 5e, 7, 9, and 11 . In particular, the inferred base of the Holocene is at $\sim 9$ mbsf $(9.9 \mathrm{mcd}$ ) in Hole U1305C. The Core MD99-2227 record also shows that interglacials are associated with high magnetic susceptibility values (Turon and HillaireMarcel, 1999). Lightness ( $\left.\mathrm{L}^{*}\right)$ measurements from Site U1305 mirror the magnetic susceptibility values, such that high $L^{*}$ (light) values generally correlate with low magnetic susceptibility values and vice versa (Fig. F15). This is not surprising given that sedimentary $\mathrm{CaCO}_{3}$ is usually light in color and reduces the magnetic susceptibility value by dilution of the other terrigenous components. Based on the correlation with the magnetic susceptibility record from Core MD99-2227, glacial terminations and the early interglacial conditions have low $\mathrm{L}^{*}$ (dark) values and high magnetic susceptibility values. The pattern observed at Site U1305 suggests that sediment accumulation from increased bottom current activity swamps the biogenic contribution during the termination and early interglacial intervals. Higher $L^{*}$ values and lower magnetic susceptibility values characterize the transition into a glacial. This may arise from decreased contribution of the detrital component as the bottom current weakened, allowing more $\mathrm{CaCO}_{3}$ to accumulate at Site U1305. Shipboard $\mathrm{CaCO}_{3}$ measurements are too widely spaced to test this hypothesis. High-resolution measurements of $\mathrm{CaCO}_{3}$ and other sedimentary proxies (e.g., grain size measurements) will need to be performed as part of postcruise studies to decipher the relative importance of sediment contributions to Site U1305 from the surface ocean, cryosphere, and bottom currents.

\section{Biostratigraphy}

Onboard micropaleontologic analyses using core catcher samples allows a biochronologic model for Site U1305. We give a preliminary age model based on 13 datum events derived from calcareous nannofossils, diatoms, and dinocysts (Fig. F16). The sediments at Site U1305 likely cover the latest Pliocene and the whole Pleistocene, as determined by the first occurrence (FO) of the nannofossil Gephyrocapsa caribbeanica (1.73 Ma) close to the base of the studied section.

Floral and faunal assemblages of planktonic organisms are used as indicators of the paleoceanographic conditions during the Pleistocene. All groups investigated onboard show high to moderate abundances and good preservation (Tables T3, T4, T5, T6, T7, T8, T9, T10, T11, T12, T13, T14, T15). Assemblages of all organisms indicate subpolar to polar conditions (Tables T3, T4, T5, T6, T7, T8, T9, T10, T11, T12, T13, T14, T15). The planktonic foraminifer assemblage in particular is dominated by Neogloboquadrina pachyderma (sinistral) indicating polar conditions. In general, abundances of the microfossils are higher in the upper $150 \mathrm{mcd}$ of the sequence than below (Fig. F17).

\section{Calcareous nannofossils}

Calcareous nannofossils were examined in core catcher samples from Holes U1305A-U1305C (Tables T3, T4, T5). The assemblages, which indicate the latest Pliocene-Quaternary, are characterized by good to poor preservation. The species diversity is high, and reworked nannofossils from the CretaceousMiocene are found throughout the sedimentary sequence. The correlations between holes and to the magnetostratigraphy are shown in Figure F16.

The FO of Emiliania huxleyi, which defines the Zone NN21/NN20 boundary (0.25 Ma), is placed between Samples 303-U1305A-3H-CC and 5H-CC, 303U1305B-4H-CC and 5H-CC, and 303-U1305C-5H$\mathrm{CC}$ and $6 \mathrm{H}-\mathrm{CC}$. The last occurrence (LO) of Pseudoemiliania lacunosa, which defines the base of Zone NN20 (0.41 Ma), was found in Samples 303-U1305A8H-CC, 303-U1305B-8H-CC, and 303-U1305C-9HCC. Both the LO of Reticulofenestra asanoi (0.85 Ma) and the FO of Gephyrocapsa parallela (0.95 Ma), which correspond to the interval between the base of the Brunhes Chron and the top of the Jaramillo Subchron of the Matuyama Chron, are detected in Samples 303-U1305A-14H-CC, 303-U1305B-15H-CC, and 303-U1305C-15H-CC and 303-U1305A-15H-CC, 303-U1305B-16H-CC, and 303-U1305C-16H-CC. We thus suggest an age spanning 0.85-0.95 Ma for the depth interval between 140.34 and 150.61 mcd (Fig. F16). The intervals from Samples 303-U1305A-15H$\mathrm{CC}$ to $18 \mathrm{H}-\mathrm{CC}, 303-\mathrm{U} 1305 \mathrm{~B}-16 \mathrm{H}-\mathrm{CC}$ to $20 \mathrm{H}-\mathrm{CC}$, and $303-\mathrm{U} 1305 \mathrm{C}-16 \mathrm{H}-\mathrm{CC}$ to $20 \mathrm{H}-\mathrm{CC}$ are characterized by the presence of $R$. asanoi and the absence of $G$. parallela, so they are assigned an age between 0.95 and $1.16 \mathrm{Ma}$ (FO of $R$. asanoi). The large form of Gephyrocapsa spp. ( $>6 \mu \mathrm{m})$ was found from Samples 303-U1305A-20H-CC to 22H-CC, 303-U1305B-22H- 
CC to $24 \mathrm{H}-\mathrm{CC}$, and $303-\mathrm{U} 1305 \mathrm{C}-21 \mathrm{H}-\mathrm{CC}$ to $24 \mathrm{H}-$ $\mathrm{CC}$, indicating an age ranging between 1.21 and 1.45 Ma. The FO of Gephyrocapsa oceanica, which indicates an age of $1.65 \mathrm{Ma}$, is found between Samples 303-U1305A-27H-CC and 28H-CC and 303-U1305C$29 \mathrm{H}-\mathrm{CC}$ and $30 \mathrm{H}-\mathrm{CC}$. The base of the Pleistocene, which is defined by the FO of G. caribbeanica (1.73 $\mathrm{Ma}$ ), is recognized between Samples 303-U1305A28H-CC and 30H-CC and 303-U1305C-29H-CC and $31 \mathrm{H}-\mathrm{CC}$ and is situated just above the Olduvai Subchron (285.6-306.25 mcd) (Fig. F16). The assemblages found in samples below the datums are characterized by dominance of small Gephyrocapsa spp. and Calcidiscus macintyrei and the absence of G. caribbeanica, G. oceanica, and Discoaster brouweri. This suggests that the lowermost samples of Holes U1305A and U1305C correspond to the uppermost Pliocene between 1.97 and $1.73 \mathrm{Ma}$ (Fig. F16).

\section{Planktonic foraminifers}

Planktonic foraminifers were examined in all core catcher samples from Holes U1305A-U1305C (Tables T6, T7, T8). Sediments below Samples 303-U1305A14H-CC, 303-U1305B-11H-CC, and 303-U1305C$8 \mathrm{H}-\mathrm{CC}$ are compact and were soaked in $\mathrm{H}_{2} \mathrm{O}_{2}$ solution before washing. Planktonic foraminiferal tests are common to abundant $(>10 \%$ of all particles $>63$ $\mu \mathrm{m})$ within the upper half of the cored interval. Below Samples 303-U1305A-14H-CC, 303-U1305B$14 \mathrm{H}-\mathrm{CC}$, and 303-U1305C-14H-CC, planktonic foraminifers are mostly common to rare and barren in several samples from all holes (Table T6, T7, T8). Preservation of tests is good in the upper half of the cores and often poor in the lower half.

$N$. pachyderma (sinistral) is the most frequent species downcore at Site U1305, with most of the tests being encrusted. Consequently, the sediments of Site U1305 are assigned to the N. pachyderma (sinistral) Zone in the Pleistocene (Weaver and Clement, 1987). Globigerina bulloides is occasionally dominant during the late Pleistocene. Turborotalita quinqueloba (sinistral and dextral) and $N$. pachyderma (dextral) are abundant in some sections. Globigerinita glutinata and Globorotalia inflata are present as rare species in many of the sediments. All of these species are present also in the modern North Atlantic. The minor presence of the extinct species Neogloboquadrina atlantica and Globigerina decoraperta in a few sections from Holes U1305A and U1305B is possibly caused by sediment reworking.

The planktonic foraminiferal fauna of many samples is characterized by a bimodal size distribution of very small tests $(<100 \mu \mathrm{m})$ and large tests $(>200 \mu \mathrm{m})$. The small test-size fraction includes small-sized species (e.g., Globigerinita uvula) as well as juvenile tests of larger species. The small tests are thin walled and well preserved (glassy) throughout the core interval.

An observed bimodal test-size distribution of planktonic foraminifers is possibly due to expatriation from northern areas by strong subsurface to bottom currents. All small-sized specimens are cold-water species (G. uvula, N. pachyderma, and T. quinqueloba). Following the death of foraminifers, small-sized tests settle through the water column with low velocity ( $<100 \mathrm{~m}$ per day) (Schiebel and Hemleben, 2000; Schiebel, 2002). Settling through the water column, tests can be transported by currents over several hundred kilometers (Siegel and Deuser, 1997; von Gyldenfeld et al., 2000). Finally, the small tests settle on the seafloor as allochthonous particles and mix with the autochthonous specimens. Test sink velocity of large-sized specimens is several hundred meters per day (up to $1500 \mathrm{~m}$ per day), which does not allow large-distance expatriation. Large-sized tests are possibly produced close to their location of sedimentation at the seafloor.

\section{Benthic foraminifers}

Benthic foraminifers were examined in all core catcher samples from Holes U1305A-U1305C (Table T9). Small-sized and thin-walled taxa (e.g., Gavelinopsis, Nonionella, and small Cassidulina spp.) are most abundant. Large Pullenia and Melonis specimens are frequent throughout the cores and are occasionally present in large numbers. Stainforthia concava is most frequent in the middle part of the holes (Table T9). Oridorsalis umbonatus and Nuttallides umbonifera occur in the lower part of the holes (Samples 11-CC and below). Agglutinated taxa are rare (Table T9).

Bimodal test-size distribution of benthic foraminifers may be caused by resedimentation. However, small and thin-walled tests are well preserved and could not be transported over long distances without damage. Maximum numbers of benthic foraminifers occur synchronously to the small-sized planktonic foraminiferal assemblages, the latter possibly indicating bottom currents. The same currents may have delivered organic material as a food source for the benthic community and enabled enhanced reproduction rates and benthic foraminiferal faunas that are rich in individuals.

\section{Diatoms}

Diatom assemblages were investigated in all core catcher samples from Holes U1305A-U1305C (Tables T10, T11, T12). Diatoms are abundant to common in the upper 200 mcd of the sedimentary sequence and appear well to moderately well preserved, and 
their abundance decreases and preservation becomes poorer below that depth (Fig. F17). The silicoflagellates Dictyocha fibula and Distephanus speculum and the siliceous dinoflagellate Actiniscus pentasterias occur in a few samples (Tables T10, T11, T12).

Four Quaternary diatom zones proposed by Koç et al. (1999) are determined based on three diatom datum events (Fig. F16; Tables T10, T11, T12). The LO of Proboscia curvirostris, which defines the base of the Thalassiosira oestrupii Zone, and the top of the P. curvirostris Zone (0.3 Ma, MIS 9; Koç et al., 1999) occurs between Samples 303-U1305A-4H-CC and 5H-CC, 303-U1305B-4H-CC and 5H-CC, and 303-U1305C$5 \mathrm{H}-\mathrm{CC}$ and $6 \mathrm{H}-\mathrm{CC}$. The $\mathrm{LO}$ of Neodenticula seminae (0.84-0.85 Ma, MIS 21; Koç et al., 1999) appears to be present between Samples 303-U1305A-11H-CC and $12 \mathrm{H}-\mathrm{CC}, 303-\mathrm{U} 1305 \mathrm{~B}-12 \mathrm{H}-\mathrm{CC}$ and $13 \mathrm{H}-\mathrm{CC}$, and $303-\mathrm{U} 1305 \mathrm{C}-13 \mathrm{H}-\mathrm{CC}$ and $15 \mathrm{H}-\mathrm{CC}$. The FO of $\mathrm{N}$. seminae (1.25-1.26 Ma, MIS 37; Koç et al., 1999) is detected between Samples 303-U1305A-19H-CC and 21H-CC, 303-U1305B-20H-CC and 22H-CC, and 303-U1305C-13H-CC and 21H-CC.

The diatom assemblage is dominated by resting spores of Chaetoceros spp. throughout (Tables T10, T11, T12). The high relative contribution of Chaetoceros spores in deep-basin sediments from high latitudes has been proposed to be related either to high productivity of surface waters or winnowing by bottom currents (Crosta et al., 1997). An assemblage composed of the spores of Thalassiosira gravida and the needle-shaped diatoms of the ThalassiothrixLioloma complex, accompanied by Actinocyclus curvatulus, Rhizosolenia hebetate f. semispina, and the vegetative cell of $T$. gravida, is typical of subarctic and arctic waters (Andersen et al., 2004). Influence of the warm and saline waters of the North Atlantic Current is indicated by the presence of Fragilariopsis doliolus, Coscinodiscus marginatus, and varieties of $T$. oestrupii (Andersen et al., 2004). The sea-ice-related diatom Fragilariopsis oceanica is also present in some samples. Preservation of diatoms is generally poor deeper than 200 mcd in the sediments (Tables T10, T11, T12).

\section{Radiolarians}

Radiolarians were examined in all core catcher samples from Holes U1305A and U1305B (Table T13). In the upper part of the succession (Samples 303U1305A-5H-CC to $11 \mathrm{H}-\mathrm{CC}$ and 303-U1305B-1H-CC to $9 \mathrm{H}-\mathrm{CC})$, radiolarian preservation is good and species diversity is high. The preservation changes from moderate to poor downcore. Total radiolarian abundance varies from trace to abundant because of dilution by detrital grains and diatoms. Throughout the sequences examined, the most abundant species is
Cycladophora davisiana davisiana. Actinomma leptodermum, Stylochlamidium venustum, and/or Spongodiscus spp. are also dominant in several samples.

C. davisiana davisiana occurs in most of the core catcher samples of Holes U1305A and U1305B. The sequences of these holes therefore can be assigned to the Late Pliocene-Pleistocene $C$. davisiana davisiana Zone of Goll and Bjørklund (1989).

\section{Palynomorphs}

Palynological assemblages were examined in all core catcher samples from Hole U1305A and in 16 core catcher samples from Hole U1305C (Tables T14; T15). Most samples contain abundant dinocysts (Fig. F17), with the exception of the lowest part of the sequence (below $\sim 275 \mathrm{mcd}$ ). Terrestrial palynomorphs, dominated by Pinus pollen grains, occur in low numbers throughout the sequences. Reworked palynomorphs also occur in low numbers except in Samples 303-U1305A-16H-CC, 26H-CC, 29H-CC, and 30H$\mathrm{CC}$, in which they are common. Microscopic fragments of charcoal are frequently observed in palynological slides, especially in the lower half of the sequence.

The dominant components of the dinocyst assemblages are Brigantedinium spp., Operculodinium centrocarpum, and Nematospharopsis labyrinthea. Bitectatodinium tepikiense and Spiniferites spp. are common in many samples. These taxa are also the most abundant taxa in the Pleistocene sediments of nearby Site 646 (cf. de Vernal and Mudie, 1992). At Site 646, high concentration of dinocysts ( $>1000$ cysts $/ \mathrm{cm}^{3}$ ) and dominance of $O$. centrocarpum or N. labyrinthea, together with high species diversity, characterize interglacial stages. Accordingly, Samples 303-U1305A$6 \mathrm{H}-\mathrm{CC}, 8 \mathrm{H}-\mathrm{CC}, 11 \mathrm{H}-\mathrm{CC}, 12 \mathrm{H}-\mathrm{CC}, 14 \mathrm{H}-\mathrm{CC}$, and 22H-CC and 303-U1305C-1H-CC, 3H-CC, 7H-CC, and $15 \mathrm{H}-\mathrm{CC}$ probably belong to interglacial stages.

The dinocyst assemblages contain only Filisphaera filifera. The LO of this species in the northern North Atlantic is dated $\sim 0.7 \mathrm{Ma}$ (cf. de Vernal et al., 1992). The occurrence of a few specimens of the species in Sample 303-U1304A-11H-CC suggests an age of $\sim 0.7$ Ma at 119 mcd.

\section{Paleomagnetism}

The natural remanent magnetization (NRM) of the archive-half core sections of Site U1305 were measured and remeasured after AF demagnetization in peak fields of up to $20 \mathrm{mT}$. Cores 303-U1305A-1H through 19H, Sections 303-U1305A-20H-3 and 20H4, Cores $303-\mathrm{U} 1305 \mathrm{~B}-1 \mathrm{H}$ to $16 \mathrm{H}$, and Cores 303 $\mathrm{U} 1302 \mathrm{C}-1 \mathrm{H}$ to $18 \mathrm{H}$ were AF demagnetized at $10 \mathrm{mT}$. 
Section 303-U1305C-17H-3 was demagnetized at 5 and $10 \mathrm{mT}$. Core 303-U1305B-17H and Sections 303U1305C-21H-1 and $21 \mathrm{H}-6$ were demagnetized at 10 , 15 , and $20 \mathrm{mT}$. Sections 303-U1305C-21H-2 through $21 \mathrm{H}-5$ were demagnetized at 10 and $15 \mathrm{mT}$. Sections 303-U1305A-20H-1, 20H-2, 20H-5, 20H-6, and 20H7 and Cores 303-U1305A-21H through 30H, 303U1305B-18H through 28H, 303-U1305C-20H and $22 \mathrm{H}$ through $31 \mathrm{H}$ were demagnetized at 10 and 20 $\mathrm{mT}$. The number of demagnetization steps and the peak field used reflected the demagnetization characteristics of the sediments, the severity of the drill string magnetic overprint, the shipboard protocol of not exceeding peak fields of $20 \mathrm{mT}$, and the need to maintain core flow through the laboratory. Sections completely affected by drilling disturbance were not measured. Data associated with intervals identified as drilling slurry, deformation, and exceptionally coarse deposits (see "Lithostratigraphy") were culled.

The NRM intensities at Site U1305 are strong both before and after demagnetization. The intensities show variability at both the meter scale and throughout the sequence. Intensities before demagnetization range from the high $10^{-1}$ to $>1 \mathrm{~A} / \mathrm{m}$. After demagnetization at peak fields of 10 or $20 \mathrm{mT}$, intensities are reduced to the low $10^{-1} \mathrm{~A} / \mathrm{m}$ range. Below 166 mcd, mean intensities are $\sim 50 \%$ of what they are above (Fig. F18). Meter-scale variations of a factor of 3 or 4 are observed throughout the sequence.

Steep positive inclinations observed prior to demagnetization and due to the drill string magnetic overprint are removed by peak $\mathrm{AF}$ demagnetization of 10 mT for the upper 160-200 mcd (Fig. F19). Below this depth, higher demagnetization levels were required to remove the drill string overprint. The highest peak fields used (20 mT) were only partially successful below 210 mcd (Fig. F19). Inclinations associated with normal and reversed polarities of the upper 200 mcd vary around the expected values (approximately \pm 72 ) for a geocentric axial dipole. Declinations show within-core consistency and, when Tensor tool-corrected, facilitate polarity interpretation (Fig. F20). The directional record from Holes U1305A, U1305B, and U1305C document an almostcontinuous sequence allowing correlation to the geomagnetic polarity timescale (Cande and Kent, 1995; Channell et al., 2002) (Fig. F19). The Brunhes and the upper Matuyama Chronozones including the Jaramillo Subchronozone are clearly identified. The Cobb Mountain Subchronozone and part of the Olduvai Subchronozone are also identifiable, though these polarity zones are less clear because of the incomplete removal of the normal polarity drill string magnetic overprint. Figures F19 and F20 and Tables T16 and T17 document the polarity zones and corresponding age interpretations.

\section{Composite section}

Cores were depth-shifted on the basis of magnetic susceptibility data collected with the Fast Track core logger soon after recovery. Magnetic susceptibility proved most useful for correlating between holes at Site U1305. Features in magnetic susceptibility are generally well aligned among Holes U1305A, U1305B, and U1305C (e.g., Fig. F21). The offsets and composite depths are listed in Table T18. Because of the highly disturbed nature of Core 303-U1305C$19 \mathrm{H}$, which was retrieved after an incomplete stroke of the APC, it was not possible to correlate this core to the other holes.

The sections of core used for the splice are identified in Table T19. We avoided using the first (top) section of each core because it was often disturbed. The cores from Site U1305 provide a continuous stratigraphic sequence to $\sim 295$ mcd with a single problematic interval between 197.2 and 206 mcd corresponding to Core $303-\mathrm{U} 1305 \mathrm{~B}-20 \mathrm{H}$. All core logging properties in this interval are invariant, making it difficult to correlate among holes. Consequently, this core was appended to Core 303-U1305B-19H above and spliced to Section 303-U1305A-20H-7, $2 \mathrm{~cm}$, below. We are not certain if sediment is missing at the core break between Cores 303-U1305B-19H and $20 \mathrm{H}$ or if the position of the splice to Section 303-U1305A-20H-7, $2 \mathrm{~cm}$, is correct. Below $295 \mathrm{mcd}$, Cores 303-U1305A$29 \mathrm{H}$ and $303-\mathrm{U} 1305 \mathrm{C}-31 \mathrm{H}$ were appended to the spliced section.

A growth factor (GF) of 1.10 is calculated by linear regression for all holes at Site U1305, indicating a $10 \%$ increase in mcd relative to mbsf (Fig. F22). We used this value of GF to calculate corrected meters composite depth (cmcd) presented in Table T18 to aid in the calculation of mass accumulation rates.

We calculated sedimentation rates using paleomagnetic and biostratigraphic datums. Linear regression provides a mean sedimentation rate of $17.3 \mathrm{~cm} / \mathrm{k} . \mathrm{y}$. for the entire section cored at Site U1305 (Fig. F23). Using only paleomagnetic datums, sedimentation rates are still relatively uniform with the exception of a greater mean sedimentation rate $(29.3 \mathrm{~cm} / \mathrm{k} . \mathrm{y}$.) between 1.07 and $1.19 \mathrm{Ma}$ (from the base of the Jaramillo to the top of the Cobb Mountain Subchronozones) that averages $29.3 \mathrm{~cm} / \mathrm{k}$.y. (Fig. F23). Outside this high sedimentation rate interval, the rate varies between 13.7 and $18.5 \mathrm{~cm} / \mathrm{k}$.y. (Table T20). 


\section{Geochemistry}

\section{Volatile hydrocarbons}

Concentrations of interstitial gases were routinely monitored in Hole U1305A sediments according to shipboard safety and pollution prevention protocols. A total of 30 headspace samples were collected and analyzed at a sampling resolution of one per core (Table T21). Within the upper $48.4 \mathrm{mbsf}$, methane $\left(\mathrm{C}_{1}\right)$ is present only in minor concentrations (4-19 ppmv) that are slightly higher than background levels (Fig. F24). $C_{1}$ concentrations increase sharply (from 19 to 1816 ppmv) downhole between 48.4 and 57.9 mbsf. Below 57.9 mbsf, $\mathrm{C}_{1}$ concentrations increase steadily to $33,877 \mathrm{ppmv}$ at 114.9 mbsf. From 114.9 mbsf to the bottom of the recovered section, $\mathrm{C}_{1}$ concentrations remain at relatively high values, ranging between 25,586 and 46,032 ppmv. Ethane $\left(\mathrm{C}_{2}\right)$ is present in sediments at $76.9 \mathrm{mbsf}$ and below (Fig. F24), generally increasing downhole from 2 to 14 ppmv. No hydrocarbons higher than $\mathrm{C}_{2}$ were detected.

In general, $\mathrm{C}_{1} / \mathrm{C}_{2}$ ratios decrease downhole, ranging from 2698 to 7574 (not shown; see Table T21 for data). The high $\mathrm{C}_{1} / \mathrm{C}_{2}$ ratios and the absence of measurable higher volatile hydrocarbons indicate that $\mathrm{C}_{1}$ in the sediments at Site U1305 has a biogenic origin.

\section{Sedimentary geochemistry}

A total of 58 sediment samples were collected for analysis of solid-phase geochemistry (inorganic carbon and elemental $\mathrm{C}, \mathrm{N}$, and S) at a sampling resolution of two per core from Hole U1305A. Figure F25 shows calcium carbonate $\left(\mathrm{CaCO}_{3}\right)$ concentrations, total organic carbon (TOC) contents, $\mathrm{N}$ elemental concentrations, and organic $\mathrm{C} / \mathrm{N}$ ratios for Site U1305. Results of the coulometric and elemental analyses are reported in Table T22.

$\mathrm{CaCO}_{3}$ contents for the Site U1305 samples are generally low, ranging from 0.9 to $49 \mathrm{wt} \%$ (average = $12.3 \mathrm{wt} \%$ ) (Fig. F25). Two samples with the highest carbonate contents of $>40 \mathrm{wt} \%$ at 170 and 162.2 mbsf coincide with "silt lamina" layers that are interbedded in a silty clay matrix (see "Lithostratigraphy"). No significant downhole trend is recognized for the Site U1305 carbonate profile. TOC contents at Site U1305 range between 0.1 and $0.6 \mathrm{wt} \%$ (average $=0.4 \mathrm{wt} \%)($ Fig. F25). The mean total $\mathrm{N}$ content at Site U1305 is $0.06 \mathrm{wt} \%$ (Fig. F25). TOC and N records do not show notable downhole trends. Most of the $\mathrm{C} / \mathrm{N}$ values are 3-10 (Fig. F25), indicating preservation of marine organic matter in the recovered sediments at Site U1305. Sediment samples with elevated $\mathrm{C} / \mathrm{N}$ ratios at 170 and $162.2 \mathrm{mbsf}$ are also char- acterized by relatively high $\mathrm{CaCO}_{3}$ values (48 wt\%). These samples are derived from "silt lamina" layers that are composed of inorganic carbonate and siliciclastic grains (see "Lithostratigraphy"), suggesting that the high $\mathrm{C} / \mathrm{N}$ values resulted from degradation of marine organic matter or influx of terrestrial organic matter or a combination of both. However, C/ $\mathrm{N}$ ratios must be considered with care because total $\mathrm{N}$ contents are low $(<0.1 \mathrm{wt} \%)$ through the cored sequence. None of the analyzed samples contain measurable S.

\section{Interstitial water chemistry}

A total of 14 whole-round samples were collected from Hole U1305A for shipboard interstitial water geochemical analysis. In addition to whole-round sections, interstitial waters were collected from small plug $\left(\sim 10 \mathrm{~cm}^{3}\right)$ sediment samples from the upper $\sim 100$ mbsf for shore-based studies. Results of interstitial water analyses for Site U1305 are reported in Table T23 and Figure F26.

\section{Chloride, sodium, salinity, $\mathrm{pH}$, and dissolved boron}

The chloride $\left(\mathrm{Cl}^{-}\right)$profile at Site U1305 exhibits an increasing trend downhole (Fig. F26). $\mathrm{Cl}^{-}$concentrations increase from $560 \mathrm{mM}$ in the shallowest sample $(1.5 \mathrm{mbsf})$ to $573 \mathrm{mM}$ in the deepest sample (257.4 mbsf). Pore fluid sodium $\left(\mathrm{Na}^{+}\right)$concentrations increase downhole (Fig. F26), exhibiting a trend that is similar to the chlorinity profile. The downhole increasing trends in the $\mathrm{Cl}^{-}$and $\mathrm{Na}^{+}$values below $\sim 60$ mbsf at Site U1305 suggest uptake of water molecules by diagenetic processes involving clay mineral alteration. A similar downhole chlorinide profile is reported from ODP Site 984 in the North Atlantic (Shipboard Scientific Party, 1996). Salinity (not shown) decreases downhole from $36 \mathrm{~g} / \mathrm{kg}$ in the uppermost sample (1.5 mbsf) to $33 \mathrm{~g} / \mathrm{kg}$ at $114.9 \mathrm{mbsf}$.

$\mathrm{pH}$ values generally increase downhole, ranging from 7.3 to 7.9 (Fig. F26). Boron concentrations in the interstitial water samples, mostly as boric acid $\left(\mathrm{H}_{3} \mathrm{BO}_{3}\right)$ at the measured $\mathrm{pH}$ range, generally decrease downhole from 551 to $411 \mathrm{mM}$ (Fig. F26). Boron and $\mathrm{pH}$ at Site U1305 appear to be negatively correlated $(r=-0.78)$.

\section{Alkalinity, sulfate, ammonium, and dissolved silica}

In the upper 57.9 mbsf at Site U1305, alkalinity increases steadily with depth from 9.1 to $18.9 \mu \mathrm{M}$ (Fig. F26). Alkalinity is unusually high in the uppermost sample, which is likely a combination of the high rates of sulfate $\left(\mathrm{SO}_{4}{ }^{2-}\right)$ reduction and the fact that the 
upper part of the sediment column was not recovered in Hole U1305A (see "Composite section"). Below $57.9 \mathrm{mbsf}$, alkalinity decreases to $6 \mathrm{mM}$ for the deepest sample collected at 257.4 mbsf. $\mathrm{SO}_{4}{ }^{2-}$ concentrations decrease downhole linearly from 21.5 $\mathrm{mM}$ in the shallowest sample to $0.1 \mathrm{mM}$ at 57.9 mbsf. Below this depth, $\mathrm{SO}_{4}{ }^{2-}$ values remain lower than $0.4 \mathrm{mM}$ toward the bottom of the recovered sediment section (Fig. F26).

The downhole decrease in $\mathrm{SO}_{4}{ }^{2-}$ and increase in alkalinity in the upper 57.9 mbsf at Site U1305 appear to reflect the effects of microbial $\mathrm{SO}_{4}{ }^{2-}$ reduction as recognized at other sites drilled during Expedition 303. The linear $\mathrm{SO}_{4}{ }^{2-}$ profile in the upper $48.4 \mathrm{mbsf}(r=$ 0.99 ) suggests diffusion of $\mathrm{SO}_{4}{ }^{2-}$ through the $\mathrm{SO}_{4}{ }^{2-}$ reduction zone and focused consumption of $\mathrm{SO}_{4}{ }^{2-}$ at the sulfate/methane interface (SMI), probably by anaerobic methane oxidation. The complete depletion of $\mathrm{SO}_{4}{ }^{2-}$ between 48.4 and 57.9 mbsf coincides with a sharp downhole increase in interstitial $\mathrm{C}_{1}$ concentrations (Fig. F27). Such downhole trends in the $\mathrm{SO}_{4}^{2-}$ and $\mathrm{C}_{1}$ profiles support the inferred biogenic origin of $\mathrm{C}_{1}$ at Site U1305 because interstitial $\mathrm{SO}_{4}{ }^{2-}$ generally inhibits microbial methanogenesis (Claypool and Kvenvolden, 1983; Capone and Klein, 1988), although exceptions have been observed (e.g., Mitterer et al., 2001). In addition, $\mathrm{C}_{1}$ can serve as a substrate for $\mathrm{SO}_{4}{ }^{2-}$ reduction (Hinrichs et al., 1999; Boetius et al., 2000; Nauhaus et al., 2002), thereby suppressing $\mathrm{C}_{1}$ above the SMI. The coincident alkalinity maximum at the SMI also suggests anaerobic methane oxidation because bicarbonate is a byproduct of this reaction. The downhole increase in alkalinity of $\sim 9.7 \mathrm{mM}$ within the $\mathrm{SO}_{4}{ }^{2-}$ reduction zone is smaller than the magnitude expected from the degree of $\mathrm{SO}_{4}{ }^{2-}$ reduction (i.e., $\sim 43 \mathrm{mM}$ ), implying diagenetic consumption of alkalinity in the sediments.

Ammonium $\left(\mathrm{NH}_{4}{ }^{+}\right)$concentrations increase steadily downhole over the entire drilled sequence, ranging from 0.6 to $2.5 \mathrm{mM}$ (Fig. F26). No downhole change in the direction or gradient of the $\mathrm{NH}_{4}{ }^{+}$trend is identified across the $\mathrm{SO}_{4}{ }^{2-}$ reduction/methanogenesis interface, suggesting that decomposition of organic matter and the resulting $\mathrm{NH}_{4}{ }^{+}$production persist below the $\mathrm{SO}_{4}{ }^{2-}$ reduction zone.

Dissolved silica $\left(\mathrm{H}_{4} \mathrm{SiO}_{4}\right)$ concentrations range from 589 to $840 \mu \mathrm{M}$ (average $=720 \mu \mathrm{M}$ ) (Fig. F26). Although no significant trend is recognized in the $\mathrm{H}_{4} \mathrm{SiO}_{4}$ profile, its downhole variability may reflect varying degrees of dissolution or the presence of biogenic silica in the sediments.

\section{Calcium, strontium, lithium, and barium}

In the upper 57.9 mbsf at Site U1305, pore fluid calcium $\left(\mathrm{Ca}^{2+}\right)$ concentrations decrease steadily from 7.8 $\mathrm{mM}$ to $2.6 \mathrm{mM}$ (Fig. F26). Below $57.9 \mathrm{mbsf}, \mathrm{Ca}^{2+}$ con- centrations increase toward the lowermost sample at 257.4 mbsf, in which the highest $\mathrm{Ca}^{2+}$ value of 9.4 $\mathrm{mM}$ is attained. Downhole trends in the strontium $\left(\mathrm{Sr}^{2+}\right)$ and lithium $\left(\mathrm{Li}^{+}\right)$profiles are similar to that of $\mathrm{Ca}^{2+}$ at Site U1305 (Fig. F26), although the depth of the most depleted $\mathrm{Sr}^{2+}$ concentration occurs at 38.9 mbsf, $19 \mathrm{~m}$ shallower than the $\mathrm{Ca}^{2+}$ minimum.

Downhole variabilities in interstitial water $\mathrm{Ca}^{2+}, \mathrm{Sr}^{2+}$, and $\mathrm{Li}^{+}$concentrations at Site U1305 are influenced by various diagenetic as well as diffusional processes in the sediment column. The downhole trend in $\mathrm{Ca}^{2+}$ shows an antithetic relationship to alkalinity $(r=-$ 0.96). Furthermore, the most depleted $\mathrm{Ca}^{2+}$ value at 57.9 mbsf (Fig. F26) appears to coincide with the SMI (Fig. F27). This coincidence in the $\mathrm{Ca}^{2+}, \mathrm{SO}_{4}{ }^{2-}$, and alkalinity profiles suggests precipitation of carbonate and associated consumption of alkalinity within the $\mathrm{SO}_{4}{ }^{2-}$ reduction zone down to 57.9 mbsf. The parallel downhole decrease in interstitial water $\mathrm{Sr}^{2+}$ and $\mathrm{Li}^{+}$ concentrations within the $\mathrm{SO}_{4}{ }^{2-}$ reduction zone suggests their uptake in the same diagenetic phase.

Below 57.9 mbsf, interstitial water $\mathrm{Ca}^{2+}, \mathrm{Sr}^{2+}$, and $\mathrm{Li}^{+}$ concentrations increase steadily to the bottom of the drilled sequence at Site U1305. Ca and Sr values approach or meet seawater values at the base of the cored section. Hence, the profiles may reflect precipitation only at $~ 58$ mbsf and diffusion from above and below. However, Li increases above seawater values and $\mathrm{Ca}$ and $\mathrm{Sr}$ may continue to increase below the cored interval, which may indicate dissolution of a mineral phase at depth (see "Magnesium, potassium, manganese, and iron" below).

Interstitial water barium $\left(\mathrm{Ba}^{2+}\right)$ concentrations are relatively low $(\sim 0.3-0.9 \mu \mathrm{M})$ in the upper $38.9 \mathrm{mbsf}$ (Fig. F26). Between 48.4 and 57.9 mbsf, $\mathrm{Ba}^{2+}$ concentrations rise sharply downhole from 3.3 to $16.6 \mu \mathrm{M}$. Below 57.9 mbsf to the bottom of the section, $\mathrm{Ba}^{2+}$ remains at relatively high concentrations ranging between 9.9 and $18.2 \mu \mathrm{M}$. The major shift in the $\mathrm{Ba}^{2+}$ profile between 48.4 and 57.9 mbsf appears to occur at the SMI, suggesting that the relatively high interstitial water $\mathrm{Ba}^{2+}$ concentrations below the $\mathrm{SO}_{4}{ }^{2-}$ reduction zone reflect dissolution of barite under conditions of $\mathrm{SO}_{4}{ }^{2-}$ depletion. Similar trends in interstitial water $\mathrm{Ba}^{2+}$ profiles are reported from regions of high-sedimentation-rate depositional environments on continental margins and are often associated with "barite fronts" at the SMI (e.g., Torres et al., 1996a, 1996b; Dickens, 2001).

\section{Magnesium, potassium, manganese, and iron}

Magnesium $\left(\mathrm{Mg}^{2+}\right)$ and potassium $\left(\mathrm{K}^{+}\right)$concentrations decrease steadily and consistently downhole at Site U1305 (Fig. F26). By the deepest sample at 257.4 mbsf, $\mathrm{Mg}^{2+}$ decreases by $\sim 43 \%$ to $30 \mathrm{mM}$ and $\mathrm{K}^{+}$decreases by $\sim 41 \%$ to $7 \mathrm{mM}$ from the near-seawater val- 
ues in the topmost sample. The correlation of profiles between $\mathrm{Mg}^{2+}$ and $\mathrm{K}^{+}$concentrations $(r=0.96$ ) suggests that these ions are removed from pore waters by a similar process(es). In the upper $57.9 \mathrm{mbsf}$, it appears that the gradients of the $\mathrm{Mg}^{2+}$ and $\mathrm{K}^{+}$profiles are shallower than those in underlying sediments, implying a possible change in mechanisms governing the consumption of $\mathrm{Mg}^{2+}$ and $\mathrm{K}^{+}$ions across the depth of alkalinity maximum. The linear diffusional profiles of $\mathrm{Mg}^{2+}$ and $\mathrm{K}^{+}$concentrations below $57.9 \mathrm{mbsf}$ ( $r=0.98$ for the both profiles) indicate that these ions are being consumed in reactions within or below the cored interval, probably associated with silicate reactions (i.e., silicate diagenesis or alteration of basement). The downhole decreases in $\mathrm{Mg}^{2+}$ and $\mathrm{K}^{+}$and increase in $\mathrm{Ca}^{2+}$ (below the SMI) are characteristic of profiles above altering basement (Gieskes and Lawrence, 1981). By comparison with Site 646 nearby, which cored deeper to $767 \mathrm{mbsf}$ (Shipboard Scientific Party, 1987), alteration of basement is the likely cause of the $\mathrm{Mg}^{2+}, \mathrm{K}^{+}$, and lower $\mathrm{Ca}^{2+}$ profiles.

Pore fluid manganese $\left(\mathrm{Mn}^{2+}\right)$ concentrations are relatively high in the upper $29.4 \mathrm{mbsf}(21.5-32.3 \mu \mathrm{M})$, decrease sharply down to $57.9 \mathrm{mbsf}$, and remain at relatively low values of $4.3-8.8 \mu \mathrm{M}$ to the bottom of the cored sequence (Fig. F26). The relatively high $\mathrm{Mn}^{2+}$ values in the upper 29.4 mbsf suggest that the samples are derived from the lowermost part of the $\mathrm{Mn}^{2+}$ reduction zone. Iron $\left(\mathrm{Fe}^{2+}\right)$ concentrations range from 3.4 to $19.8 \mu \mathrm{M}$ but do not show any significant downhole trend (Fig. F26). The low interstitial water $\mathrm{Fe}^{2+}$ concentrations indicate sequestration of dissolved ions into iron sulfides, which are observed in the sediments (see "Lithostratigraphy").

\section{Physical properties}

Physical property data at Site U1305 were measured on both whole-round sections and discrete samples for split core sections. Whole-core susceptibility was measured every $5 \mathrm{~cm}$ at Site U1305. $P$-wave velocity ( $P$-wave sensor number 3 [PWS3]) was measured once per section for all cores where possible. We collected samples from each core in Hole U1305A for discrete moisture and density (MAD) measurements. Most cores from Site U1305 were unaffected by core disturbance, showing similar records across all holes.

\section{Whole-core magnetic susceptibility measurements}

The magnetic susceptibility records are highly variable because of lithologic and/or mineralogic changes and show multiple excursions toward high values (Fig. F28). Magnetic susceptibility measure- ments were obtained from the "fast track" magnetic susceptibility core logger (MSCL) and the multisensor track (MST). Both records present the same trends. Peak magnetic susceptibility values from the MST range from $860 \times 10^{-5}$ to $1300 \times 10^{-5}$ SI and coincide with peak gamma ray attenuation (GRA) density values $\left(1.7-2 \mathrm{~g} / \mathrm{cm}^{3}\right)$, suggesting rapid and frequent deposition of different-sourced sediments and indicating important mineralogical changes at this site. The peaks in magnetic susceptibility commonly correspond to sand-silt laminae (see "Lithostratigraphy"). Lower magnetic susceptibility values $(200 \times$ $10^{-5}$ to $300 \times 10^{-5} \mathrm{SI}$ ) commonly coincide with the presence of light-colored, silt-sized detrital carbonate layers (e.g., Core 303-U1305A-12H), which have been described as typical glacial deposits in this region (e.g., Hillaire-Marcel et al., 1994; Stoner et al., 1995b, 1996) and are partially related to ice-rafting events. Higher variability in magnetic susceptibility peaks in the lower part of the cored interval may indicate increased transport of magnetic particles to Site U1305.

\section{Density}

The GRA density values covary with the magnetic susceptibility records, with the main peaks characterized by values around $1.7-2.2 \mathrm{~g} / \mathrm{cm}^{3}$ (Fig. F29). Low density values oscillate between 1.4 and $1.5 \mathrm{~g} / \mathrm{cm}^{3}$, reaching $1.2 \mathrm{~g} / \mathrm{cm}^{3}$ between 304 and $309 \mathrm{mcd}$. Discrete bulk density values fall generally within the higher range of GRA density values, in particular below $\sim 70$ mcd (Core 303-U1305A-9H). However, one exception was identified (162-169.98 mcd) where the discrete measurements are higher than the MSTderived values.

\section{Natural gamma radiation}

Natural gamma radiation (NGR) counts range from 14 to $51 \mathrm{cps}$ with the majority of the values between 21 and 38 cps (Fig. F30). The peak values usually reflect zones enriched in clay minerals. Even at the bottom of the drilled interval, which is dominated by coarser sandy silt laminae within silty clay sediments (see "Lithostratigraphy"), high values of NGR suggest that these intervals contain significant amounts of clay minerals. The NGR variability does not correspond to the magnetic susceptibility and GRA density records.

\section{P-wave velocity}

$P$-wave velocities range from 1500 to $1600 \mathrm{~m} / \mathrm{s}$ at the top of the sedimentary sequence (upper $\sim 50 \mathrm{mcd}$ ) (Fig. F31). Both velocity records from the MST ( $P$ wave logger $[\mathrm{PWL}])$ and the split-core measurements 
(PWS3) show an increase in velocity between 16.6 and 27 mcd. Below $~ 50-60$ mcd, the scatter in measurements increases. At Site U1305 we experienced several problems measuring acoustic velocities, both with the MST-mounted PWL and the PWS3. Signal strength deteriorated completely from $\sim 60$ to $74 \mathrm{mcd}$ (around Cores 303-U1305A-8H and $9 \mathrm{H}$ and 303$\mathrm{U} 1305 \mathrm{~B}-7 \mathrm{H}$ and $8 \mathrm{H}$ ), often generating readings with values lower than that of seawater. Elevated methane concentrations may be the cause of $P$-wave signal attenuation, as there is a rapid increase in methane concentrations at $\sim 50-60 \mathrm{mcd}$ in all holes at Site U1305 (see "Geochemistry"). We also see an offset in PWL and PWS3 measurements that is a longstanding "calibration" problem not unique to Expedition 303 (see "Physical properties" in the "Site U1302-U1308 methods" chapter).

\section{Porosity}

Discrete MAD sample measurements from Hole U1305A show a steady increase in bulk density from 1.4 to $1.8 \mathrm{~g} / \mathrm{cm}^{3}$. The GRA density-derived porosity (see "Physical properties" in the "Sites U1302-U1308 methods" chapter) and discrete pycnometer measurements (Fig. F32) agree well. Although highly variable, porosity decreases from values of $81 \%-78 \%$ to $~ 40 \%-$ $43 \%$ at the bottom of Holes U1305A and U1305B.

\section{Discussion}

The physical property data document the rapid and frequent changes in the sediment composition in response to different paleoceanographic, biological, and ice sheet changes. Three main types of sedimentation regimes are proposed to explain the physical property relationships (Fig. F33). Interglacial periods are characterized by higher deposition rates than glacial intervals and by high magnetic susceptibility and density values. Glacial periods are characterized by low magnetic susceptibility, low GRA density, and low NGR counts, possibly due to the deposition of fine detrital carbonate layers within a silty clay-dominated sediment. NGR increases toward the transition between detrital carbonate and terrigenousdominated layers, suggesting a relative increase in the clay component, which seems to be a likely cause for the offset between high NGR values and the magnetic susceptibility and GRA peaks. Two intervals where physical properties are relatively invariant with low magnetic susceptibility and low density values (60-100 and $\sim 190-209$ mcd, respectively) correspond to more carbonate-rich sediments (see "Lithostratigraphy").

Although this is not a region of high productivity, the high sedimentation rates, particularly during in- terglacial intervals, may have contributed to rapid burial of organic matter in the sediments and the subsequent consumption during methanogenesis. This process gave rise to a high percentage of trapped gas in the pores after retrieval. With respect to physical properties, the most clearly observed effect of the elevated gas concentration was difficulty in measuring acoustic velocities from $\sim 60$ to $75 \mathrm{mcd}$ (Cores 303-U1305A-7H, 8H, and 9H and 303-U1305B-8H and $9 \mathrm{H})$. In addition, one would expect gas to result in anomalous porosity estimates.

\section{Downhole measurements}

\section{Logging operations}

Downhole logging was performed in Hole U1305C after it had been drilled to a depth of $287.1 \mathrm{mbsf}$ and displaced with sepiolite mud (see "Operations"). The pipe was initially set at 95.3 mbsf. Prior to logging, it was expected that two tool string configurations would be run, the triple combo with the MultiSensor Spectral Gamma Ray Tool (MGT) and the FMS-sonic (see "Downhole measurements" in the "Site U1302-U1308 methods" chapter). However, because of the problems detailed below, only the triple combo-MGT was deployed successfully. An impassable bridge was encountered at 265.9 mbsf. A successful main pass was made from this depth to above the seafloor. In an attempt to save time, it was decided to run only a shortened repeat pass, and thus the tool string was lowered to $\sim 204.2$ mbsf. As the tool string approached the base of the pipe, the caliper arm failed to close, so logging was stopped. After many attempts to close the caliper, it was clear that it was failing to respond. Furthermore, it became clear that the tool could not be pulled, even partially, into the pipe and was probably trapped by the float valve. After $\sim 3 \mathrm{~h}$ of pumping and altering the position of the pipe, the tool string eventually reentered the pipe and was pulled back to the surface. On the basis of the problems encountered downhole (most likely caused by the moderate to large heave) and an assessment of the state of the hole, it was decided to terminate logging operations. Inspection of the wireline revealed that it had indeed become trapped in the float valve. The caliper arm was missing and had most likely been lost in the open hole immediately prior to the first attempt to reenter the pipe. Details of the intervals logged and the position of the drill bit are shown in Figure F34. During logging operations, weather was poor and the sea state was moderate to rough with a typical heave of $2.5-3.5 \mathrm{~m}$ and peaks of $>4 \mathrm{~m}$. The wireline heave compensator was used throughout the logging operations in the open hole. 


\section{Data quality}

The caliper data show that the diameter of the borehole ranged from $~ 13.6$ to 18.0 inches (Fig. F35), resulting in data of variable quality. Reproducibility of data is high between passes (see gamma ray example in Fig. F35). The density and porosity tools require good borehole contact, and intervals with a large borehole diameter are characterized by high porosities and low densities (Fig. F36). Density and porosity data are also less reliable when the caliper is not open (i.e., above 107 mbsf during the main pass).

\section{Results}

The downhole logging data suggest that the formation is fairly uniform in the open hole. As expected, the density and porosity data are generally inversely related to each other and show downhole trends of increasing density and decreasing porosity. Resistivity values are low, reflecting the generally moderateto high-porosity sediments. Photoelectric effect factor (PEF) values range between 1.0 and $3.3 \mathrm{~b} / \mathrm{e}^{-}$, consistent with the clay-rich lithologies (see "Lithostratigraphy"). Extremely low PEF values $\left(<1.8 \mathrm{~b} / \mathrm{e}^{-}\right.$, the PEF value of pure quartz) may be the result of poor contact with the borehole wall or extremely porous intervals (seawater $\mathrm{PEF}=0.807 \mathrm{~b} / \mathrm{e}^{-}$).

Gamma ray values increase slightly with depth, possibly as a result of increasing clay content (Fig. F37). The low uranium content of the formation results in very similar total spectral gamma ray (HSGR) and computed gamma ray headspace ([HCGR], summation of Th and $\mathrm{K}$ gamma rays only) values. The uranium data suggest that TOC values in the logged interval are consistently very low, as shown by discrete samples (see "Geochemistry"). Potassium and thorium display very similar trends downhole, suggesting that there are no major downhole changes in mineralogy.

\section{Core-logging comparisons}

All the downhole data sets display meter- to decimeter-scale variability that are most likely the result of subtle changes in lithology. A comparison of logging- and core-derived NGR and density records shows close agreement in downhole trends and patterns (Fig. F38). Measured density values are very similar in both core and logging data. Closer inspection of the gamma ray data suggests that $5 \mathrm{~m}$ scale patterns can be recognized in both the core and logging records (Fig. F38). Using the downhole logging records as a depth reference, it will be possible to map core measurements to equivalent logging depths using the software program Sagan to more precisely determine the amount of core expansion.

\section{References}

Aksu, A.E., de Vernal, A., and Mudie, P.J., 1989. High-resolution foraminifer, palynologic, and stable isotopic records of upper Pleistocene sediments from the Labrador Sea: paleoclimatic and paleoceanographic trends. In Srivastava, S.P., Arthur, M.A., Clement, B., et al., Proc. ODP, Sci. Results, 105: College Station, TX (Ocean Drilling Program), 617-652. [PDF]

Andersen, C., Koç, N., and Moros, M., 2004. A highly unstable Holocene climate in the subpolar North Atlantic: evidence from diatoms. Quat. Sci. Rev., 23:21552166. doi:10.1016/j.quascirev.2004.08.004

Arthur, M.A., Srivastava, S.P., Kaminski, M., Jarrard, R., and Osler, J., 1989. Seismic stratigraphy and history of deep circulation and sediment drift development in Baffin Bay and the Labrador Sea. In Srivastava, S.P., Arthur, M.A., Clement, B., et al., Proc. ODP, Sci. Results, 105: College Station, TX (Ocean Drilling Program), 957-988. [PDF]

Boetius, A., Ravenschlag, K., Schubert, C.J., Rickert, D., Widdel, F., Gieseke, A., Amann, R., Jørgensen, B.B., Witte, U., and Pfannkuche, O., 2000. A marine microbial consortium apparently mediating the anaerobic oxidation of methane. Nature (London, U. K.), 407:623626. doi:10.1038/35036572

Cande, S.C., and Kent, D.V., 1995. Revised calibration of the geomagnetic polarity timescale for the Late Cretaceous and Cenozoic. J. Geophys. Res., 100:6093-6095. doi:10.1029/94JB03098

Capone, D.G., and Klein, R.P., 1988. Comparison of microbial dynamics in marine and freshwater sediments: contrast in anaerobic carbon catabolism. Limnol. Oceanogr., 33:725-749.

Channell, J.E.T., Sato, T., Kanamatsu, T., Stein, R., Malone, M.J., and the Expedition 303/306 Project Team, 2004. North Atlantic climate. IODP Sci. Prosp., 303/306. doi:10.2204/iodp.sp.303306.2004

Channell, J.E.T., Mazaud, A., Sullivan, P., Turner, S., and Raymo, M.E., 2002. Geomagnetic excursions and paleointensities in the Matuyama Chron at ODP Sites 983 and 984 (Iceland Basin). J. Geophys. Res., 107. doi:10.1029/2001JB000491

Chough, S., 1985. Contourites from Eirik Drift, south of Greenland. Sediment. Geol., 41:185-199.

Chough, S., Hesse, R., and Müller, J., 1987. The northwest Atlantic mid-ocean channel of the Labrador Sea, IV. Petrography and provenance of the sediments. Can. J. Earth Sci., 24:731-740.

Claypool, G.E., and Kvenvolden, K.A., 1983. Methane and other hydrocarbon gases in marine sediment. Annu. Rev. Earth Planet. Sci., 11:299-327. doi:10.1146/ annurev.ea.11.050183.001503

Clement, B.M., Hall, F.J., and Jarrard, R.D., 1989. The magnetostratigraphy of Ocean Drilling Program Leg 105 sediments. In Srivastava, S.P., Arthur, M.A., Clement, B., et al., Proc. ODP, Sci. Results, 105: College Station, TX (Ocean Drilling Program), 583-595. [PDF]

Cremer, M., 1989. Texture and microstructure of NeogeneQuaternary sediments, ODP Sites 645 and 646, Baffin Bay and Labrador Sea. In Srivastava, S.P., Arthur, M.A., 
Clement, B., et al., Proc. ODP, Sci. Results, 105: College Station, TX (Ocean Drilling Program), 7-20. [PDF]

Crosta, X., Pichon, J.-J., and Labracherie, M., 1997. Distribution of Chaetoceros resting spores in modern peri-Antarctic sediments. Mar. Micropaleontol., 29:283-299. doi:10.1016/S0377-8398(96)00033-3

de Vernal, A., and Mudie, P.J., 1992. Pliocene and Quaternary dinoflagellate cyst stratigraphy in Labrador Sea: paleocological implications. In Head, M.J., and Wrenn, J.H. (Eds.), Neogene and Quaternary Dinoflagellate Cysts and Acritarchs: Salt Lake City (Publisher's Press), 329346.

de Vernal, A., Londeix, L., Mudie, P.J., Harland, R., Morzadec-Kerfourn, M.T., Turon, J.-L., and Wrenn, J.H., 1992. Quaternary organic-walled dinoflagellate cysts of the North Atlantic Ocean and adjacent seas: ecostratigraphy and biostratigraphy. In Head, M.J., and Wrenn, J.H. (Eds.), Neogene and Quaternary Dinoflagellate Cysts and Arcritarchs: Salt Lake City (Publisher's Press), 289-328.

Dickens, G.R., 2001. Sulfate profiles and barium fronts in sediment on the Blake Ridge: present and past methane fluxes through a large gas hydrate reservoir. Geochim. Cosmochim. Acta, 65:529-543. doi:10.1016/S00167037(00)00556-1

Gieskes, J.M., and Lawrence, J.R., 1981. Alteration of volcanic matter in deep-sea sediments: evidence from the chemical composition of interstitial waters from deep sea drilling cores. Geochim. Cosmochim. Acta, 45:16871703. doi:10.1016/0016-7037(81)90004-1

Goll, R.M., and Bjørklund, K.R., 1989. A new radiolarian biostratigraphy for the Neogene of the Norwegian Sea: ODP Leg 104. In Eldholm, O., Thiede, J., Taylor, E., et al., Proc. ODP, Sci. Results, 104: College Station, TX (Ocean Drilling Program), 697-737. [PDF]

Hall, F.R., Bloemendal, J., King, J.W., Arthur, M.A., and Aksu, A.E., 1989. Middle to late Quaternary sediment fluxes in the Labrador Sea, ODP Leg 105, Site 646: a synthesis of rock-magnetic, oxygen-isotopic, carbonate, and planktonic foraminiferal data. In Srivastava, S.P., Arthur, M.A., Clement, B., et al., Proc. ODP, Sci. Results, 105: College Station, TX (Ocean Drilling Program), 653688. [PDF]

Hesse, R., and Chough, S.K., 1980. The Northwest Atlantic Mid-Ocean Channel of the Labrador Sea: II. Deposition of parallel laminated levee-muds from the viscous sublayer of low density turbidity currents. Sedimentology, 27:697-711.

Hillaire-Marcel, C., and Bilodeau, G., 2000. Instabilities in the Labrador Sea water mass structure during the last climatic cycle. Can. J. Earth Sci., 37:795-809. doi:10.1139/cjes-37-5-795

Hillaire-Marcel, C., de Vernal, A., Bilodeau, G., and Wu, G., 1994. Isotope stratigraphy, sedimentation rates, deep circulation, and carbonate events in the Labrador Sea during the last $200 \mathrm{ka}$. Can. J. Earth Sci., 31:63-89.

Hinrichs, K.-U., Hayes, J.M., Sylva, S.P., Brewer, P.G., and DeLong, E.F., 1999. Methane consuming archaebacteria in marine sediments. Nature (London, U. K.), 398:802805 .
Hiscott, R.N., Aksu, A.E., Mudie, P.J., and Parsons, D.F., 2001. A 340,000 year record of ice-rafting, paleoclimatic fluctuations, and shelf-crossing glacial advances in the southwestern Labrador Sea. Global Planet. Change, 28: 227-240. doi:10.1016/S0921-8181(00)00075-8

Hiscott, R.N., Cremer, M., and Aksu, A.E., 1989. Evidence from sedimentary structures for processes of sediment transport and deposition during post-Miocene time at Sites 645, 646, and 647, Baffin Bay and the Labrador Sea. In Srivastava, S.P., Arthur, M.A., Clement, B., et al., Proc. ODP, Sci. Results, 105: College Station, TX (Ocean Drilling Program), 53-63. [PDF]

Koç, N., Hodell, D.A., Kleiven, H., and Labeyrie, L., 1999. High-resolution Pleistocene diatom biostratigraphy of Site 983 and correlations with isotope stratigraphy. In Raymo, M.E., Jansen, E., Blum, P., and Herbert, T.D. (Eds.), 1999. Proc. ODP, Sci. Results, 162: College Station, TX (Ocean Drilling Program), 51-62. [HTML]

Mitterer, R.M., Malone, M.J., Goodfriend, G.A., Swart, P.K., Wortmann, U.G., Logan, G.A., Feary, D.A., and Hine, A.C., 2001. Co-generation of hydrogen sulfide and methane in marine carbonate sediments. Geophys. Res. Lett., 28:3931-3934. doi:10.1029/2001GL013320

Nauhaus, K., Boetius, A., Kruger, M., and Widdel, F., 2002. In vitro demonstration of anaerobic oxidation of methane coupled to sulfate reduction in sediment from a gas hydrate area. Environ. Microbiol., 4:296-305. doi:10.1046/j.1462-2920.2002.00299.x

Schiebel, R., 2002. Planktic foraminiferal sedimentation and the marine calcite budget. Global Biogeochem. Cycles, 16(4):10. doi:1029/2001GB001459

Schiebel, R., and Hemleben, C., 2000. Interannual variability of planktic foraminiferal populations and test flux in the eastern North Atlantic Ocean (JGOFS). Deep-Sea Res., Part II, 47(9-11):1809-1852.

Shipboard Scientific Party, 1987. Site 646. In Srivastava, S.P., Arthur, M., Clement, B., et al., Proc. ODP, Init. Repts., 105: College Station, TX (Ocean Drilling Program), 419-674. [PDF]

Shipboard Scientific Party, 1996. Site 984. In Jansen, E., Raymo, M.E., Blum, P., et al., Proc. ODP, Init. Repts., 162: College Station, TX (Ocean Drilling Program), 169-222.

Siegel, D.A., and Deuser, W.G., 1977. Trajectories of sinking particles in the Sargasso Sea: modeling of statistical funnels above deep-ocean sediment traps. Deep-Sea Res., Part I, 44:1519-1541.

Smith, W.H.F., and Sandwell, D.T., 1994. Bathymetric prediction from dense satellite altimetry and sparse shipboard bathymetry. J. Geophys. Res., 99:21803-21824. doi:10.1029/94JB00988

Stoner, J.S., Channell, J.E.T., and Hillaire-Marcel, C., 1995a. Late Pleistocene relative geomagnetic paleointensity from the deep Labrador Sea: regional and global correlations. Earth Planet. Sci. Lett., 134:237-252. doi:10.1016/ 0012-821X(95)00134-X

Stoner, J.S., Channell, J.E.T., and Hillaire-Marcel, C., 1995b. Magnetic properties of deep-sea sediments off the southwest Greenland: evidence for major differences between the last two deglaciations. Geology, 
23:241-244. doi:10.1130/0091-

7613(1995)023<0241:MPODSS>2.3.CO;2

Stoner, J.S., Channell, J.E.T., and Hillaire-Marcel, C., 1996. The magnetic signature of rapidly deposited detrital layers from the deep Labrador Sea: relationship to North Atlantic Heinrich layers. Paleoceanography, 11:309-325. doi:10.1029/96PA00583

Stoner, J.S., Channell, J.E.T., and Hillaire-Marcel, C., 1998. A 200 ka geomagnetic chronostratigraphy for the Labrador Sea: indirect correlation of the sediment record to SPECMAP. Earth Planet. Sci. Lett., 159:165-181. doi:10.1016/S0012-821X(98)00069-7

Torres, M.E., Bohrmann, G., and Suess, E., 1996a. Authigenic barites and fluxes of barium associated with fluid seeps in the Peru subduction zones. Earth Planet. Sci. Lett., 170:1-15. doi:10.1016/S0012-821X(96)00163-X

Torres, M.E., Brumsack, H.-J., Bohrmann, G., and Emeis, K.C., 1996b. Barite fronts in continental margin sediments: a new look at barium remobilization in the zone of sulfate reduction and formation of heavy barites in diagenetic fronts. Chem. Geol., 127:125-139. doi:10.1016/0009-2541(95)00090-9

Turon, J.-L., Hillaire-Marcel, C., and Shipboard Participants, 1999. IMAGES V mission of the Marion Dufresne, Leg 2, 30 June to 24 July 1999. Geol. Surv. Canada, Open File 3782 .

von Gyldenfeldt, A.B., Carstens, J., and Meincke, J., 2000. Estimation of the catchment area of a sediment trap by means of current meters and foraminiferal tests. In Ganssen, G., and Wefer, G. (Eds.), Particle Flux and Its Preservation in Deep Sea Sediments. Deep-Sea Res., Part II, 47:1701-1717.

Weaver, P.P.E., and Clement, B.M., 1987. Magnetobiostratigraphy of planktonic foraminiferal datums, DSDP Leg 94, North Atlantic. In Ruddiman, W.F., Kidd, R.B., Thomas, E., et al., Init. Repts. DSDP, 94: Washington (U.S. Govt. Printing Office), 815-829.

Publication: 9 September 2006 MS 303ER-105 
Figure F1. Location of Site U1305 relative to other sites drilled during Expedition 303. Black and blue arrows indicate deep- and surface-current trajectories, respectively. Sediment deposition at all sites is influenced by these currents and by turbiditic flow down the Northwest Atlantic Mid-Ocean Channel (NAMOC). Cross-section from southwest (SW) to the vicinity of Site U1306 (lower frame) indicates location of sites relative to principal water bodies. Shaded region in central Labrador Sea indicates main area of formation of Labrador Sea Water $(\mathrm{LSW})$. WBUC = Western Boundary Undercurrent, CGFZ = Charlie Gibbs Fracture Zone, LC = Labrador Current, NAD = North Atlantic Drift, WGC $=$ West Greenland Current, NEADW $=$ Northeast Atlantic deep water, DSOW $=$ Denmark Strait Overflow Water, NADW = North Atlantic Deep Water (modified after HillaireMarcel and Bilodeau, 2000).

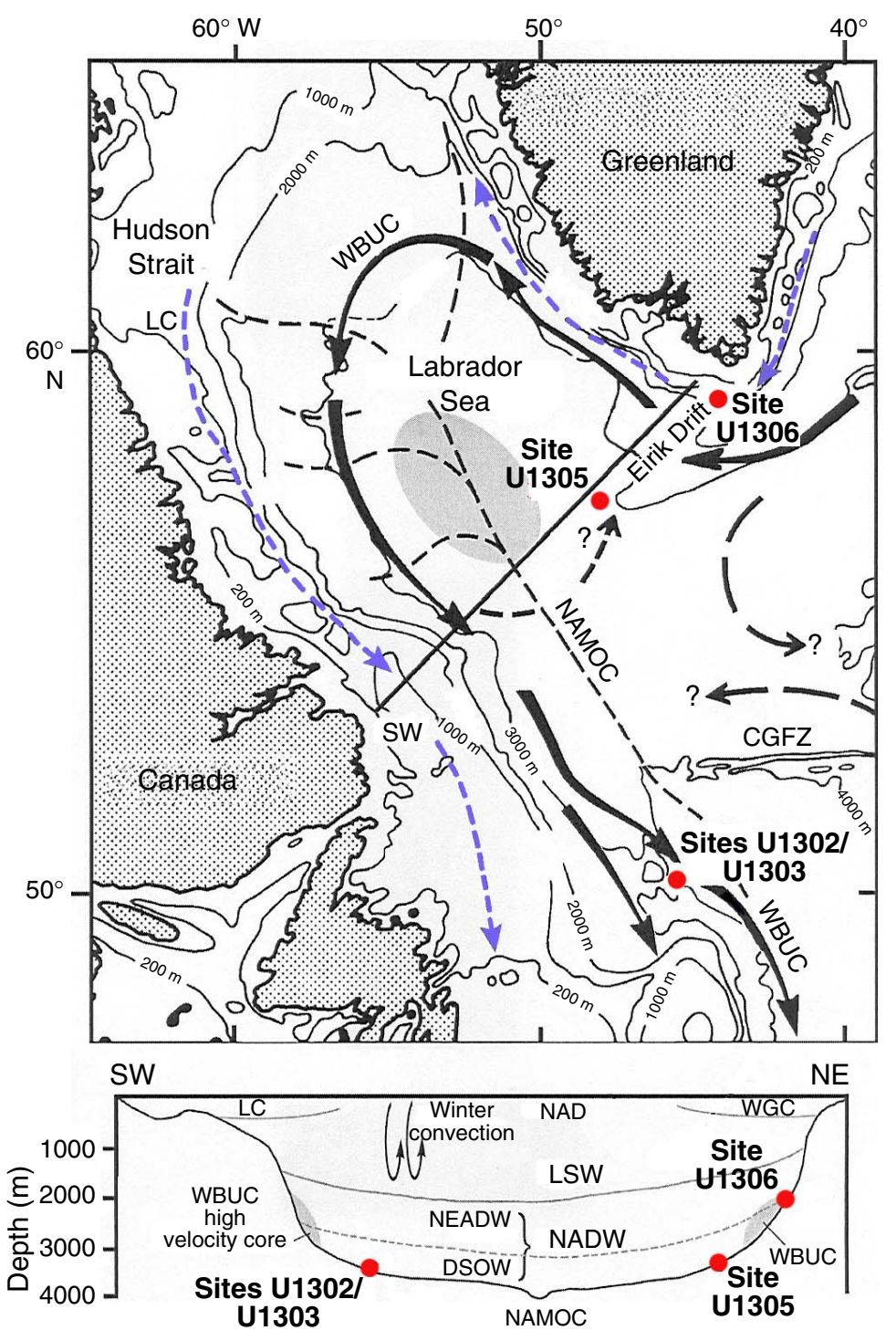


Figure F2. Location of Site U1305 relative to ODP Site 646 . The two sites are separated by $82.2 \mathrm{~km}$. Bathymetric from Smith and Sandwell (1994).

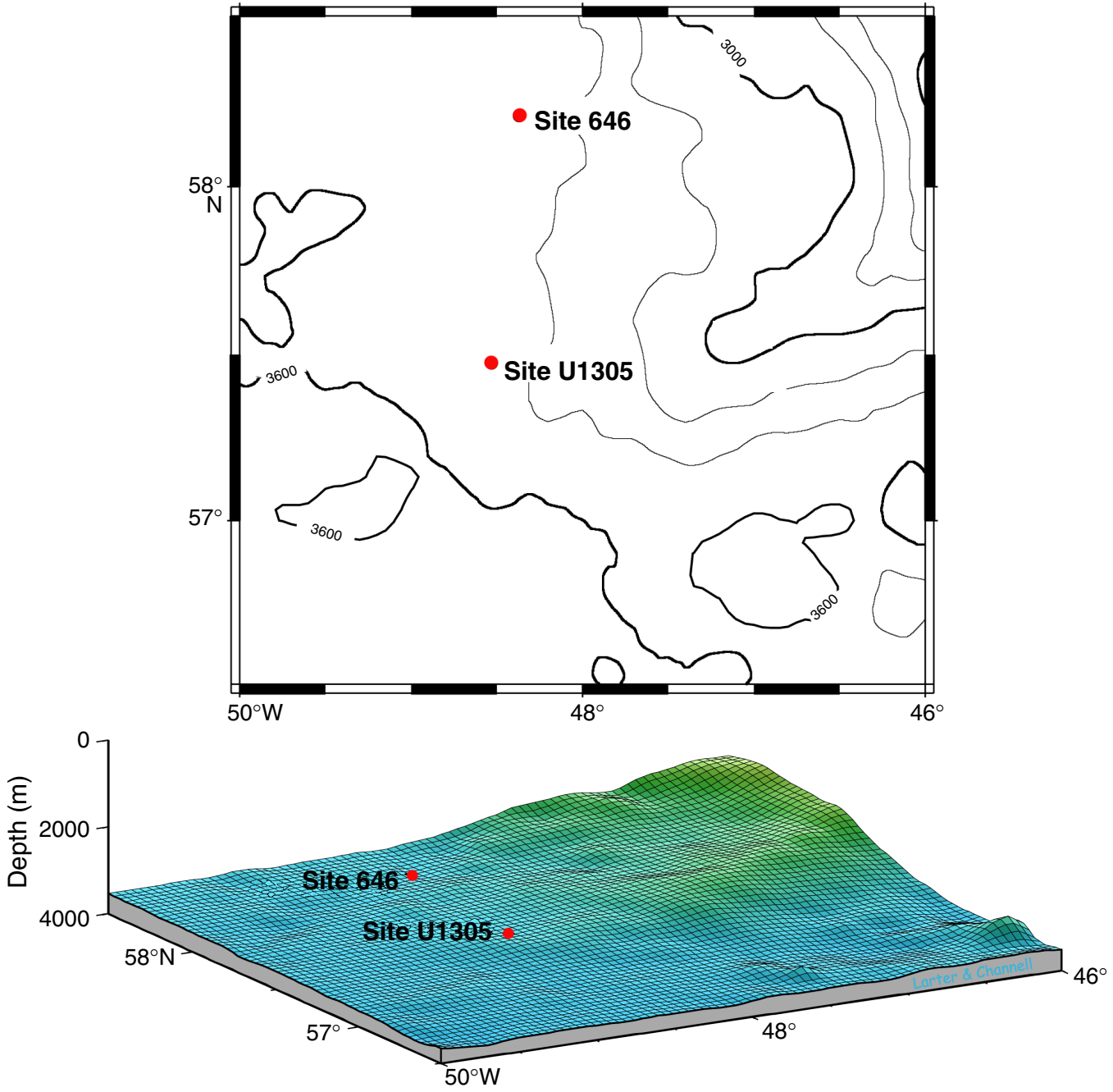


Figure F3. Map of multichannel seismic lines collected during Knorr Cruise KN166-14 in 2002, relative to the seismic lines collected in 1977 by BGR1 and BGR2. The location of the deepwater site (Site U1305) and the shallower water site (Site U1306) are shown relative to the location of ODP Site 646 (Mountain et al., unpubl. data).

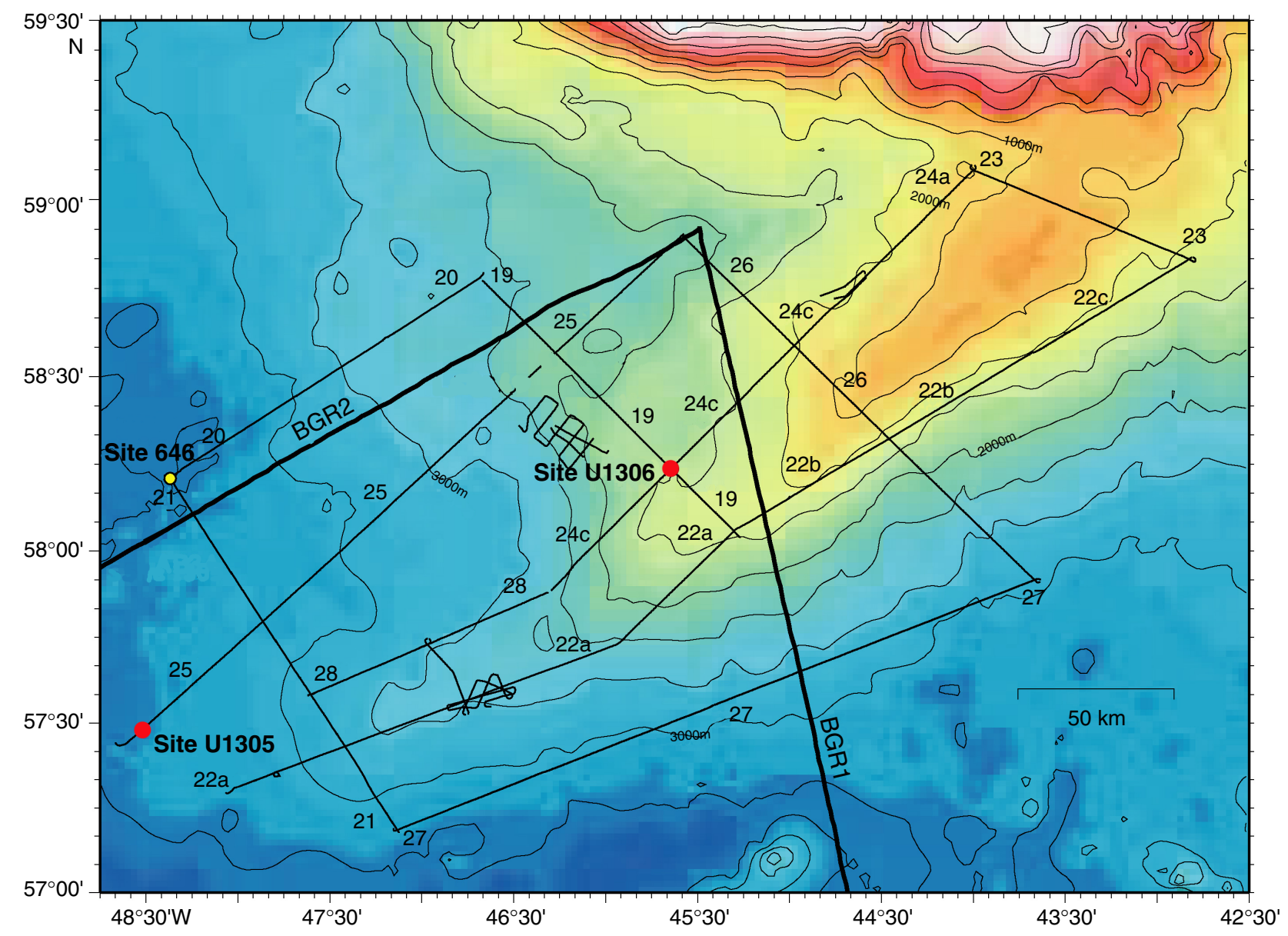


Figure F4. Multichannel seismic record across Site U1305 obtained along seismic Line 25 (Fig. F3) during Knorr Cruise KN166-14. The location of the R1 seismic reflector, correlated to the mid-Upper Pliocene at ODP Site 646, and the estimated (actual) penetration at Site U1305 (base of Quaternary) are indicated (Mountain et al., unpubl. data).

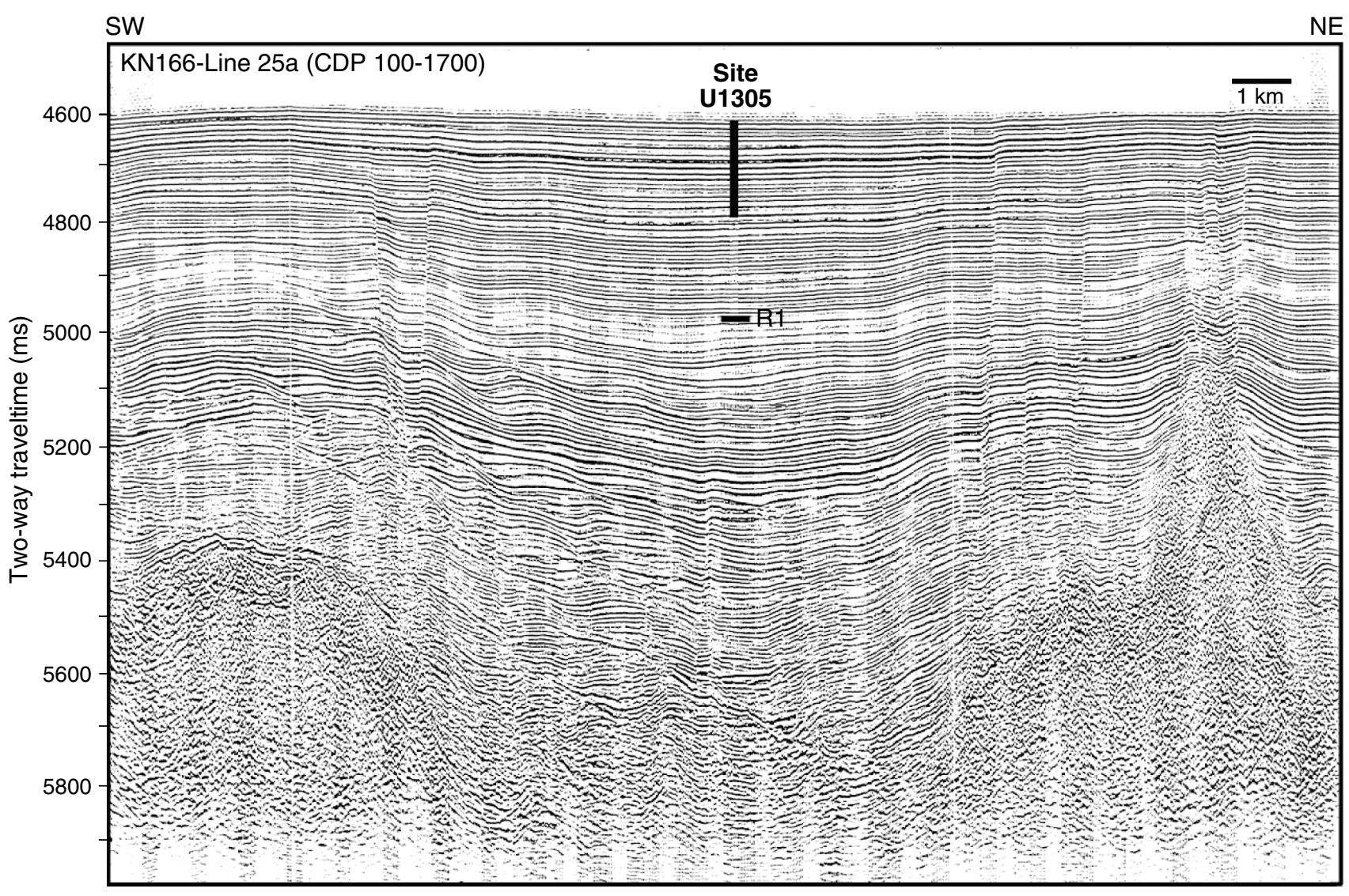


Figure F5. 3.5 kHz data at Site U1305 obtained from seismic Line 25 during Knorr Cruise KN166-14 (Mountain et al., unpubl. data).

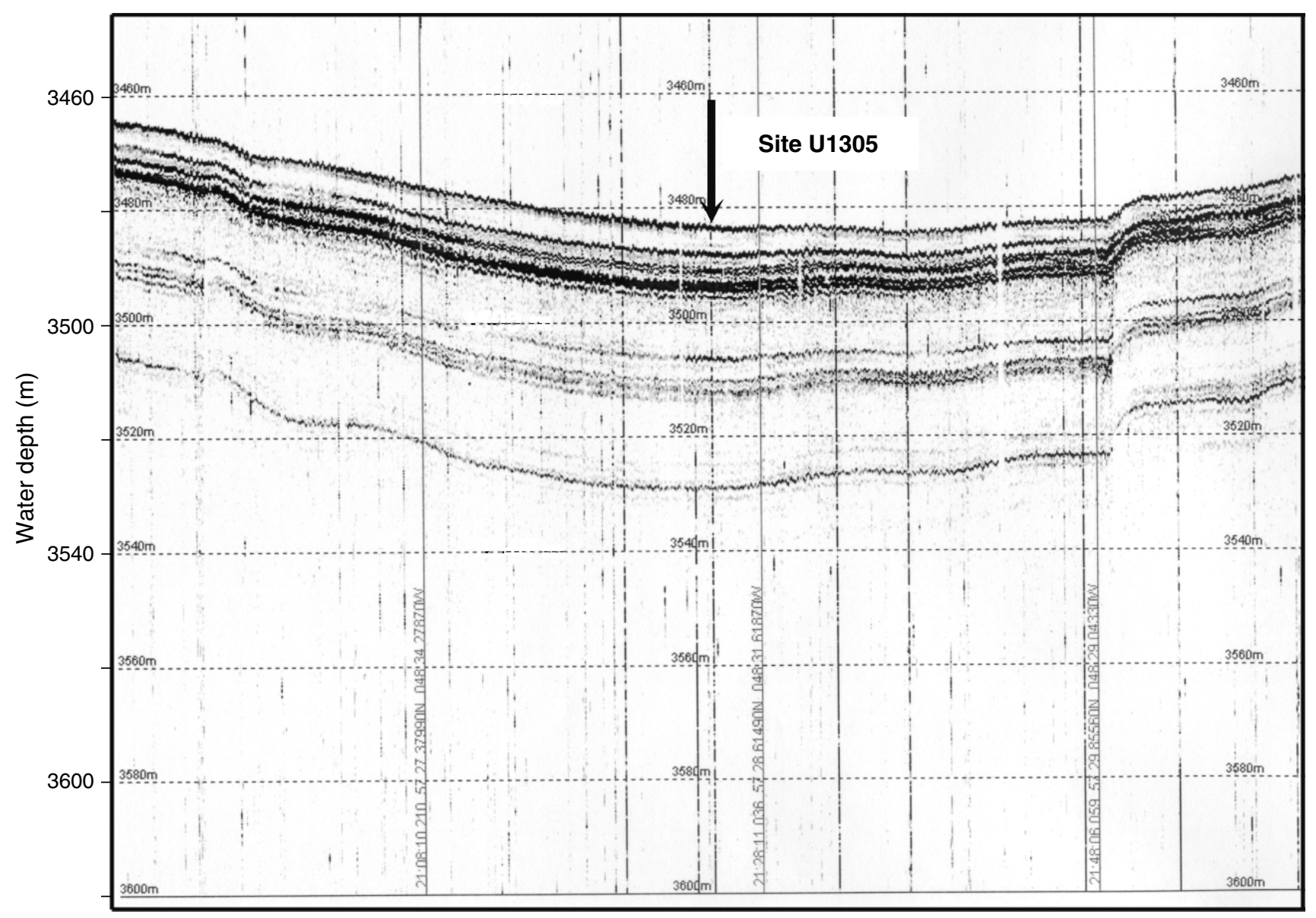


Figure F6. Volume magnetic susceptibility (MS) records for Cores HU90-013-013 (Stoner et al., 1995a, 1996) and MD99-2227 (Turon et al., 1999), and MS for ODP Site 646 (Shipboard Scientific Party, 1987; Hall et al., 1989). The correlations indicate substantial stretching in the upper part of Core MD99-2227. MST = multisensor track.

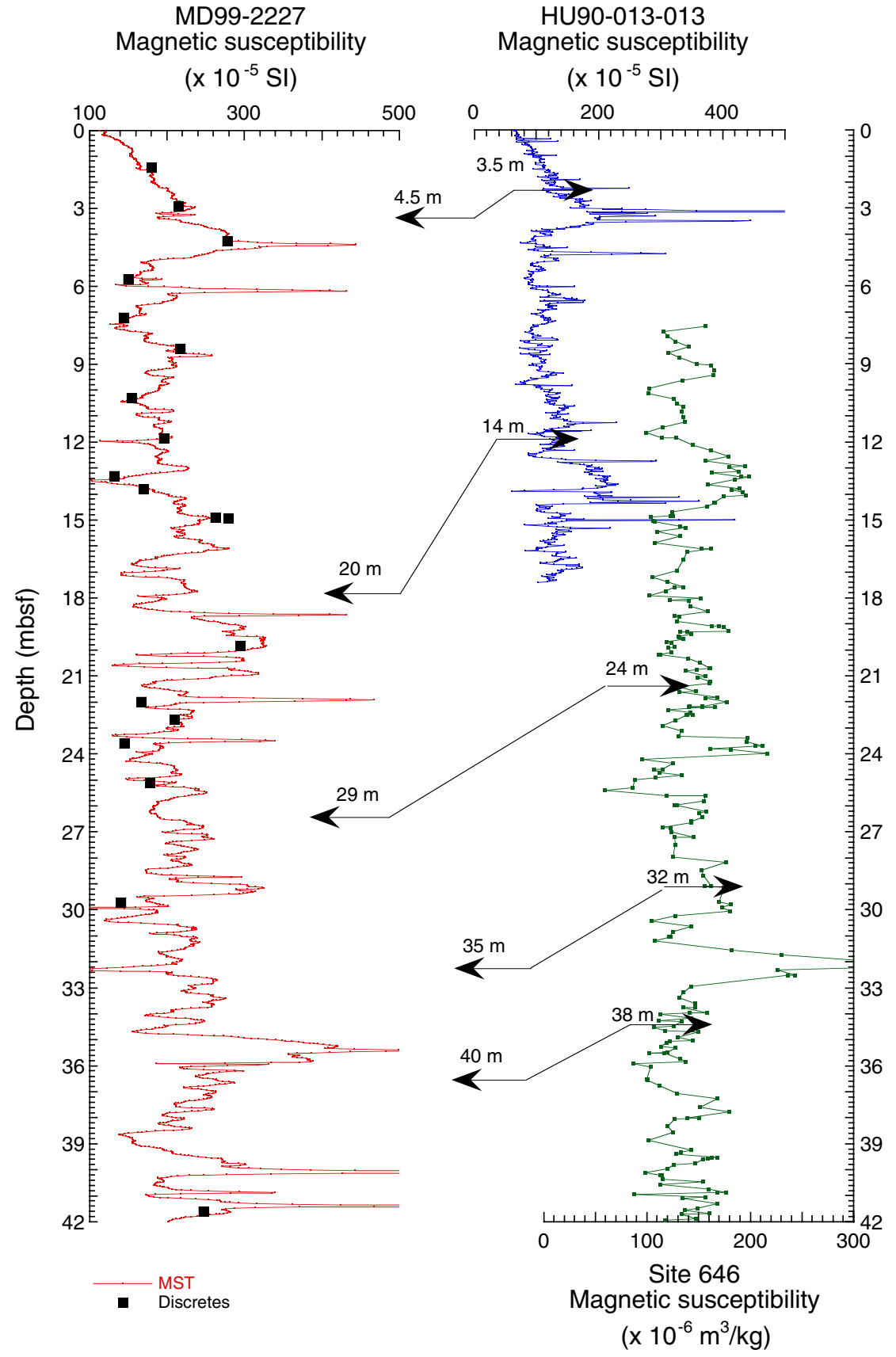


Figure F7. Abundances of calcite, clay, and quartz. Black dots $=$ Hole U1305A data, red squares $=$ Hole U1305B data, blue triangles $=$ Hole U1305C data.

Site 1305 Smear Slide Mineralogy

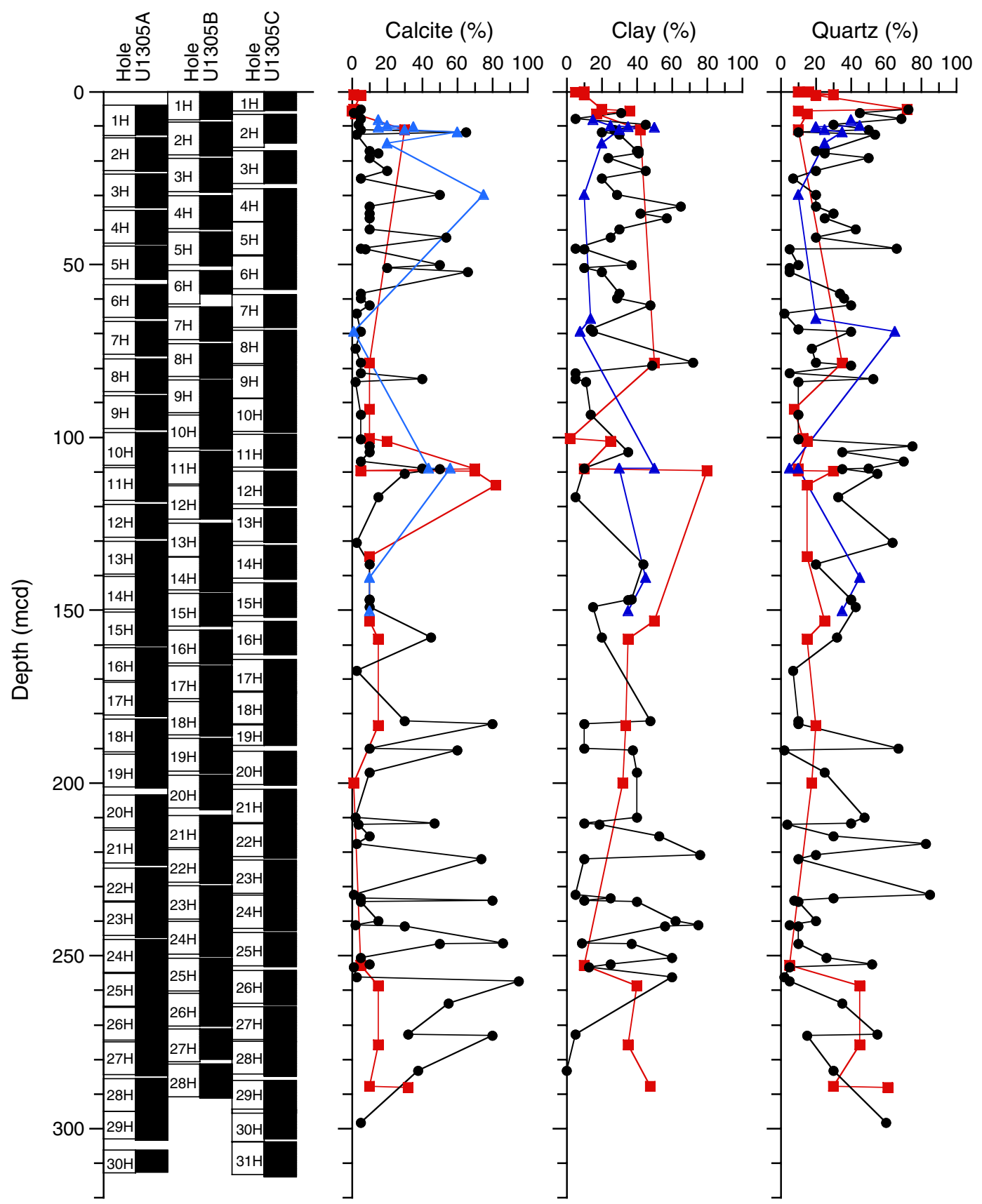


Figure F8. Graphic summary of the lithologies recovered at Site U1305.

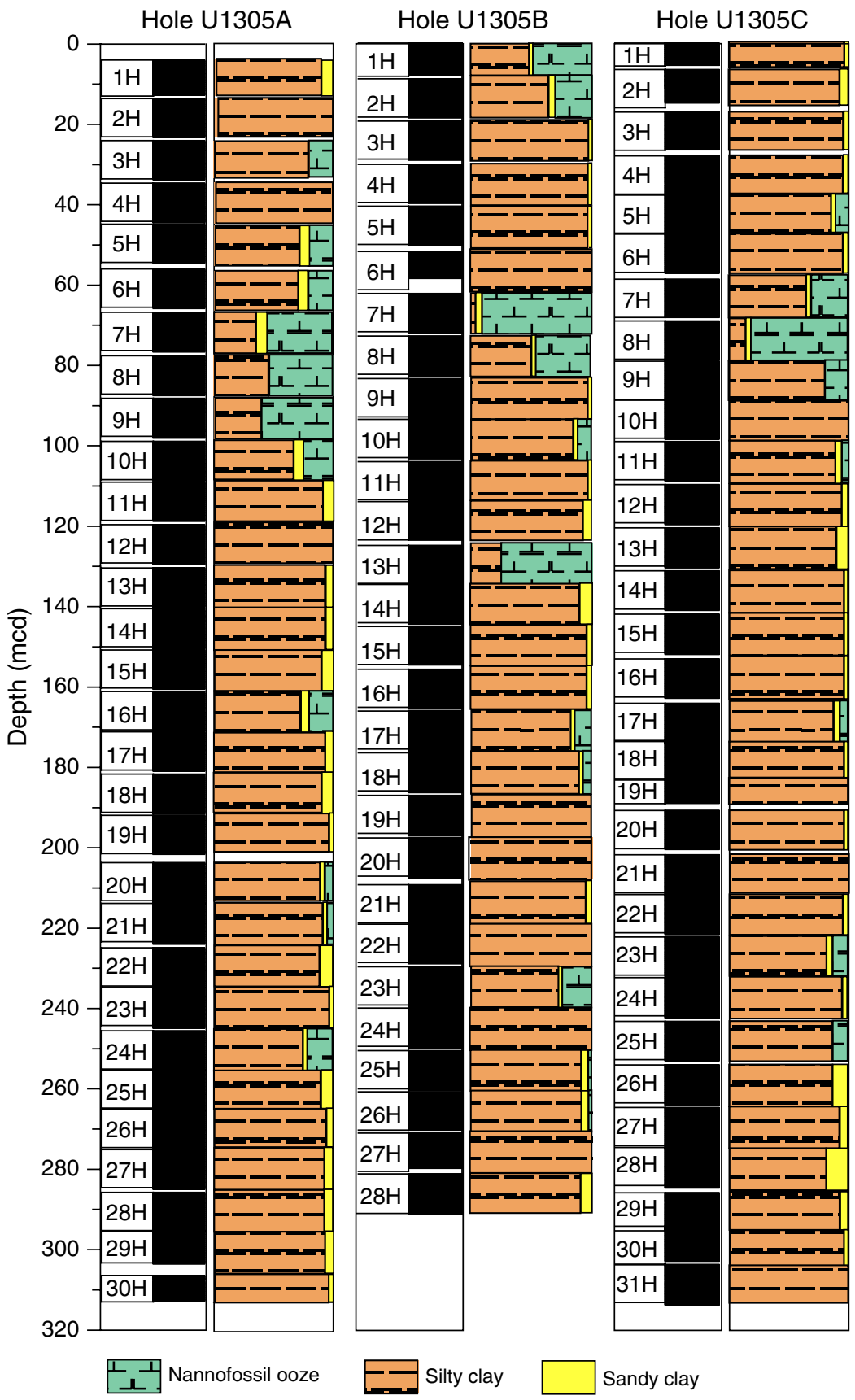


Figure F9. Oxidized layer at top of Unit I (interval 303-U1305C-1H-1, 0-25 cm).

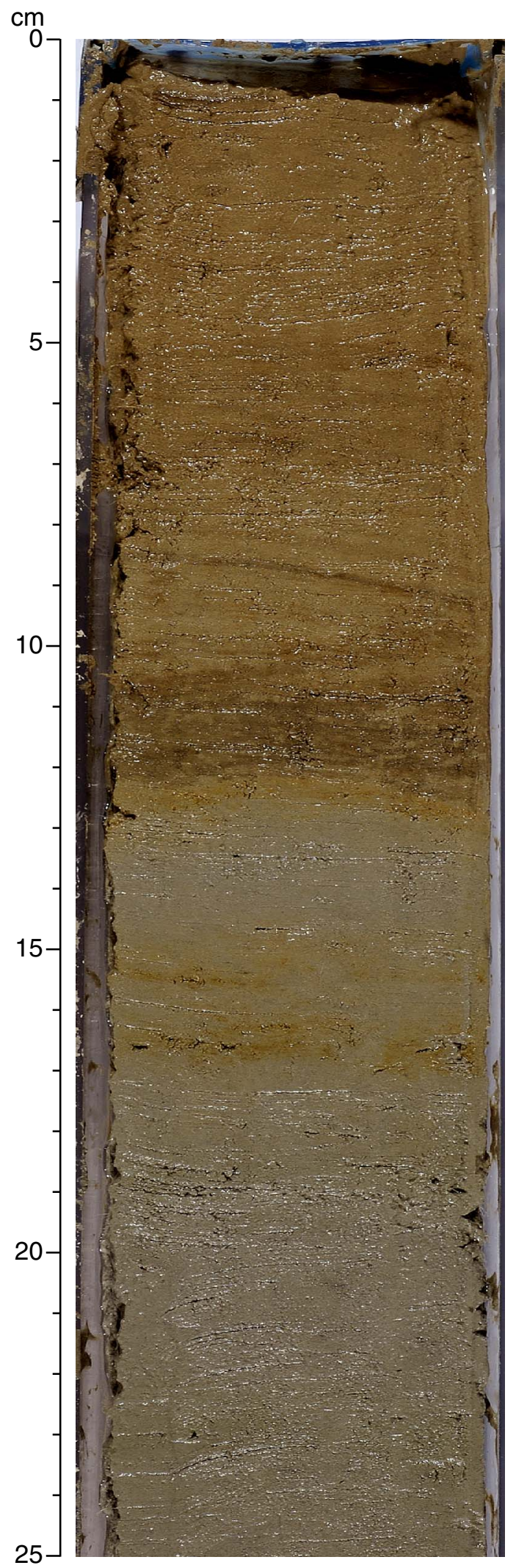


Expedition 303 Scientists

Site U1305

Figure F10. Abundance of gravel-sized grains (number of grains $/ 10 \mathrm{~cm}$ length of core).
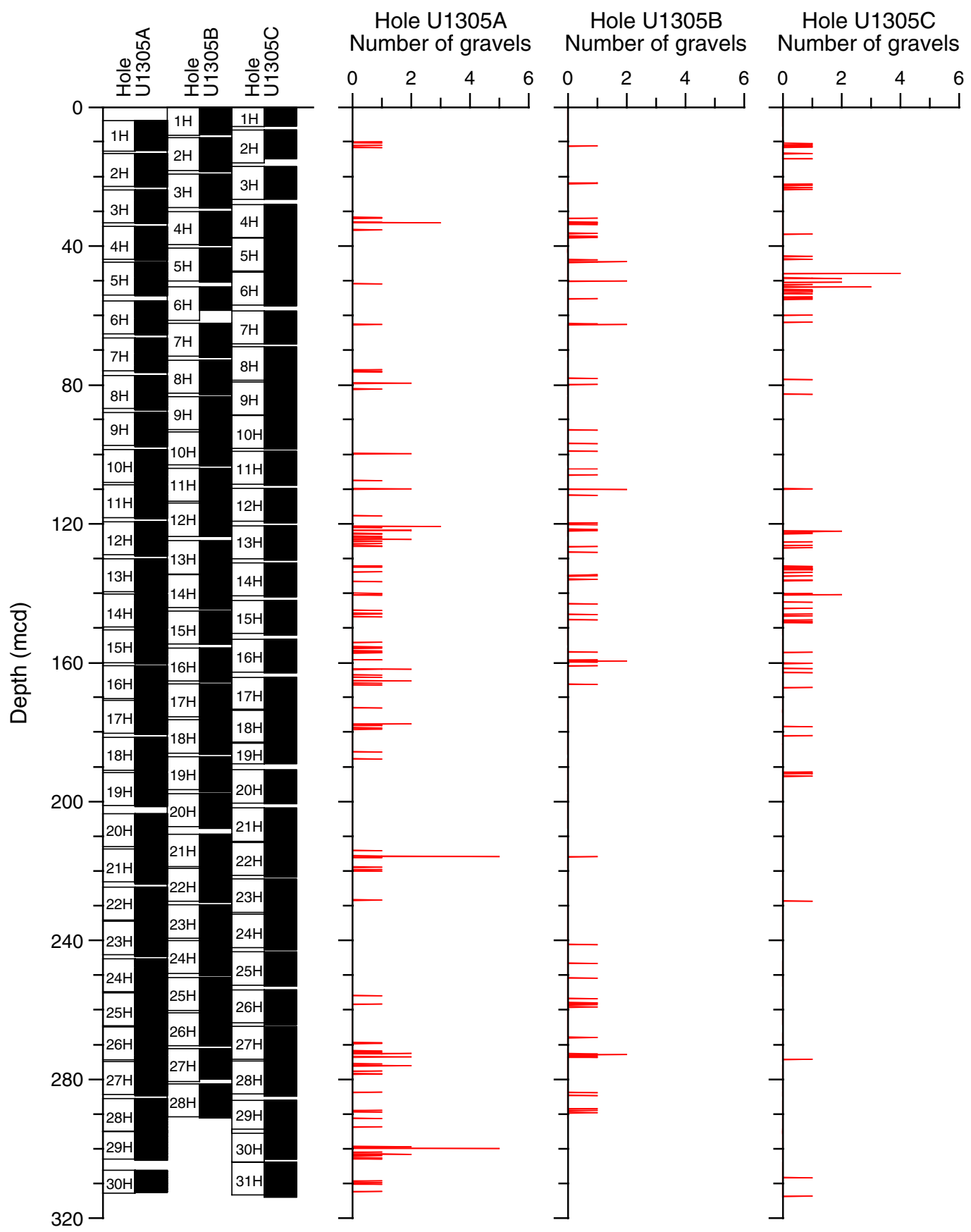

Proc. IODP | Volume 303/306

26 
Figure F11. Sandy silt laminae, some of which are cross laminated. Note sharp, irregular base (interval 303U1305A-25H-4, 90-104 cm).

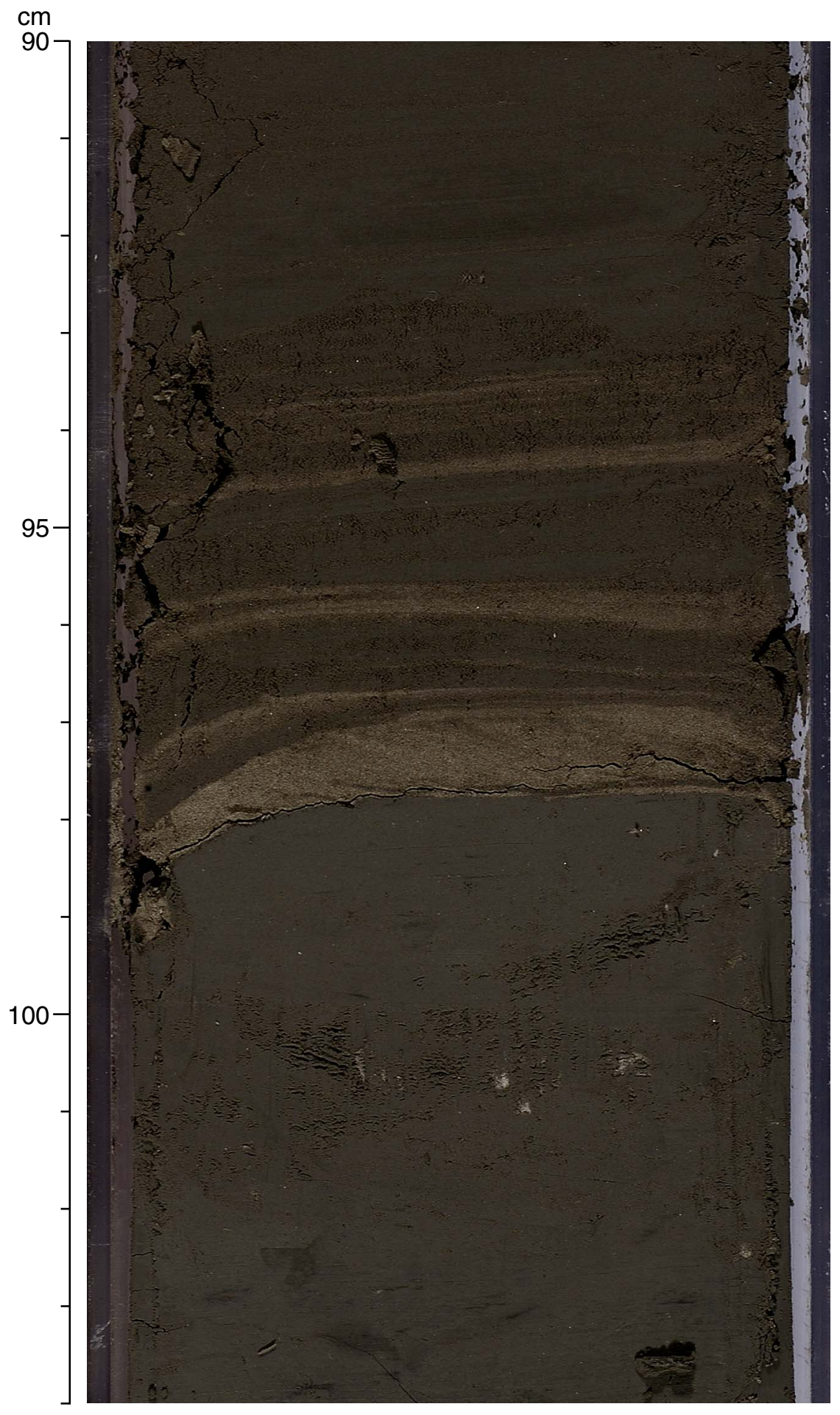


Figure F12. Detrital carbonate layer, showing sharp irregular base and bioturbated upper boundary. Note continuous to discontinuous carbonate silt laminae, some of which are cross laminated (interval 303-U1305B$16 \mathrm{H}-4,60-90 \mathrm{~cm})$.

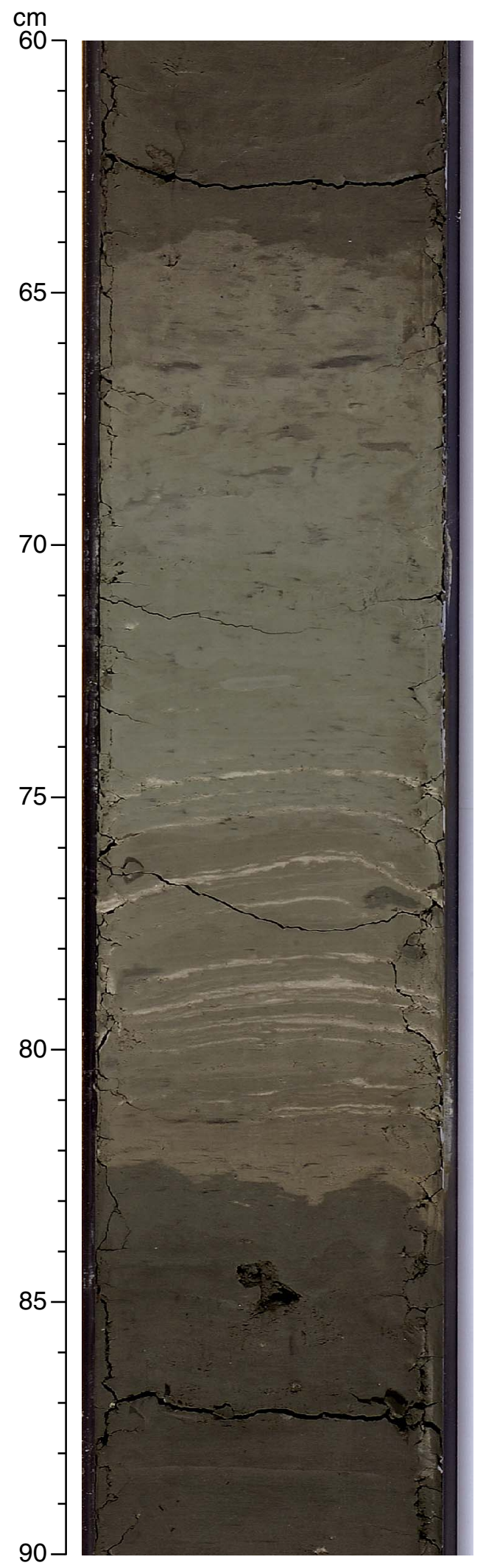


Figure F13. Detrital $\mathrm{CaCO}_{3}$ layers identified as the equivalents of the $\mathrm{H} 2$ and $\mathrm{H} 4$ events. A. Interval 303U1305C-2H-3, 100-121 cm. B. Interval 303-U1305C-2H-4, 50-70 cm.
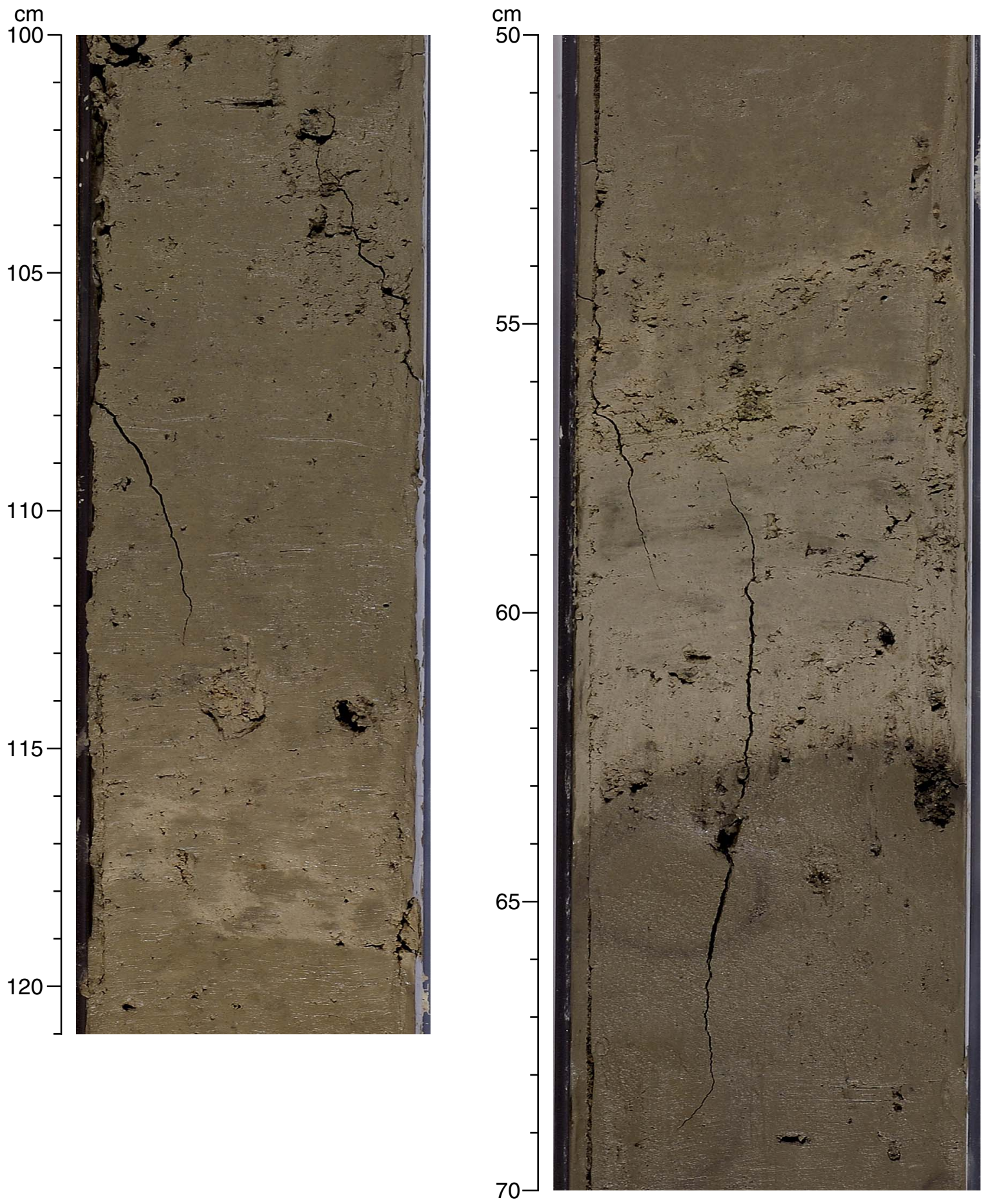
Figure F14. Comparison of spliced composite magnetic susceptibility from Site U1305 with record from Core MD99-2227 (Turon and Hillaire-Marcel, 1999). Marine isotope stages (MIS) are shown based on the Core MD99-2227 $\delta^{18} \mathrm{O}$ record (Stoner and Hillaire-Marcel, unpubl. data).

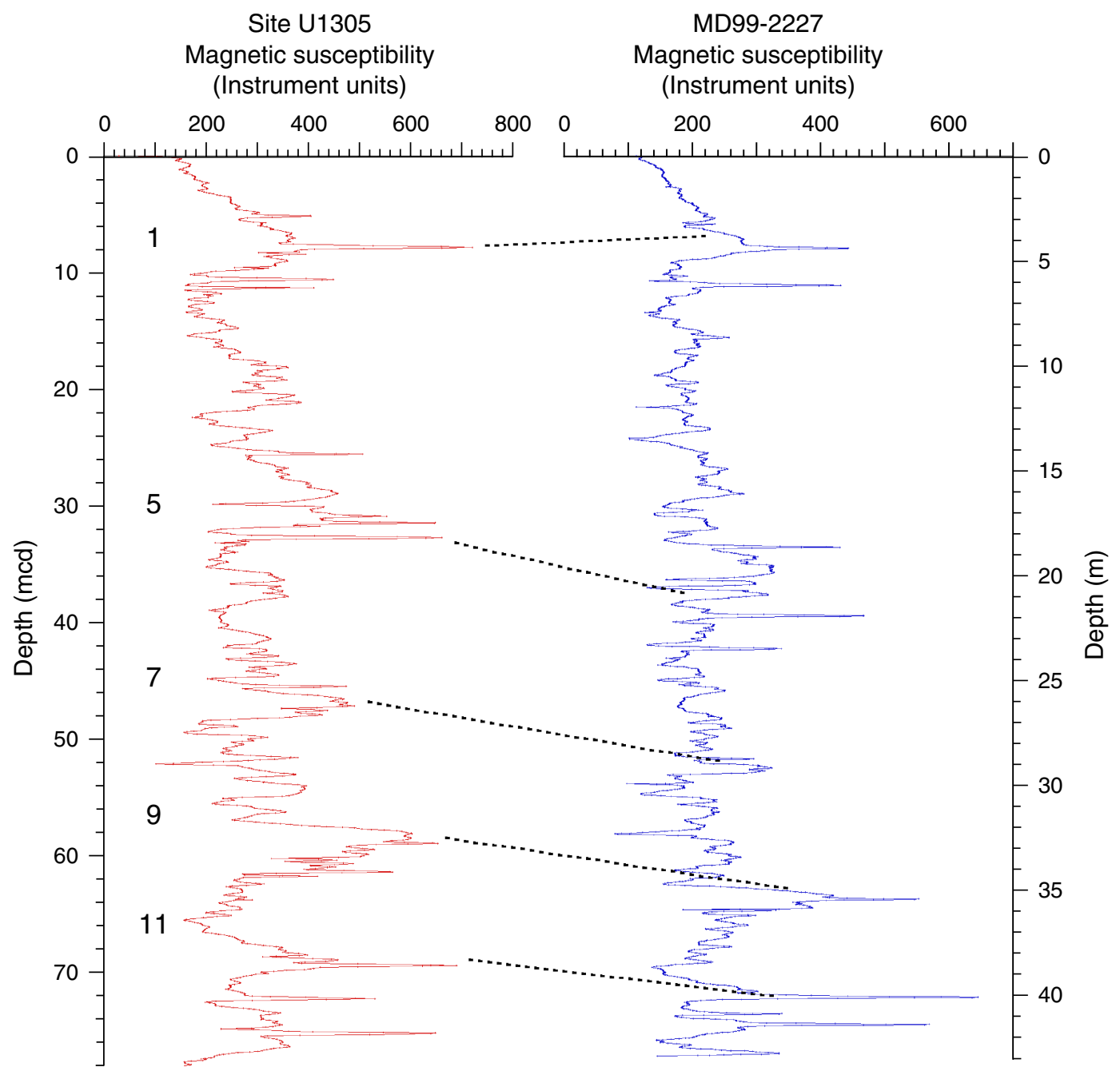


Figure F15. Comparison of the splice composite for sediment lightness $\left(\mathrm{L}^{*}\right)$ and magnetic susceptibility (MS) from Site U1305. L* individual data are shown as small dots. A 40 point boxcar filter equivalent to $80 \mathrm{~cm}$ length was used to smooth the data for presentation. The MS is shown as a red line. Marine isotope Stages (MIS) 1, 3, and 5 are identified along the bottom of the graph and were identified by correlating to the MS record to Core MD99-2227 and its $\delta^{18} \mathrm{O}$ record (see Fig. F14).

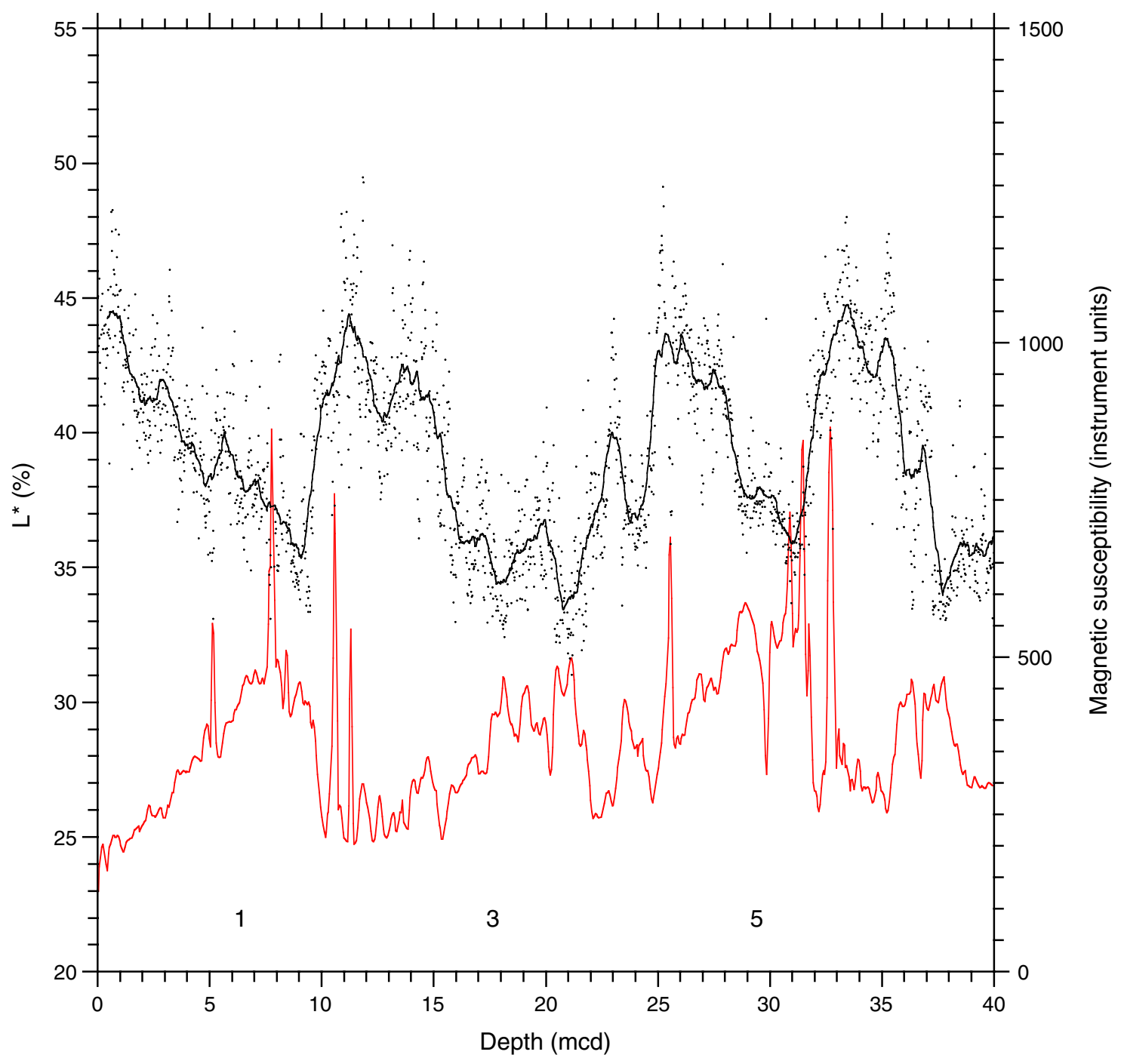


Figure F16. Chronostratigraphic correlation of Holes U1305A, U1305B, and U1305C based on calcareous nannofossils, diatoms, planktonic foraminifers, and dinocysts. Relationship to magnetostratigraphy is shown in the left panel. $\mathrm{MIS}=$ marine isotope stage, $\mathrm{LO}=$ last $\mathrm{occurrence}$, FO $=$ first occurrence.

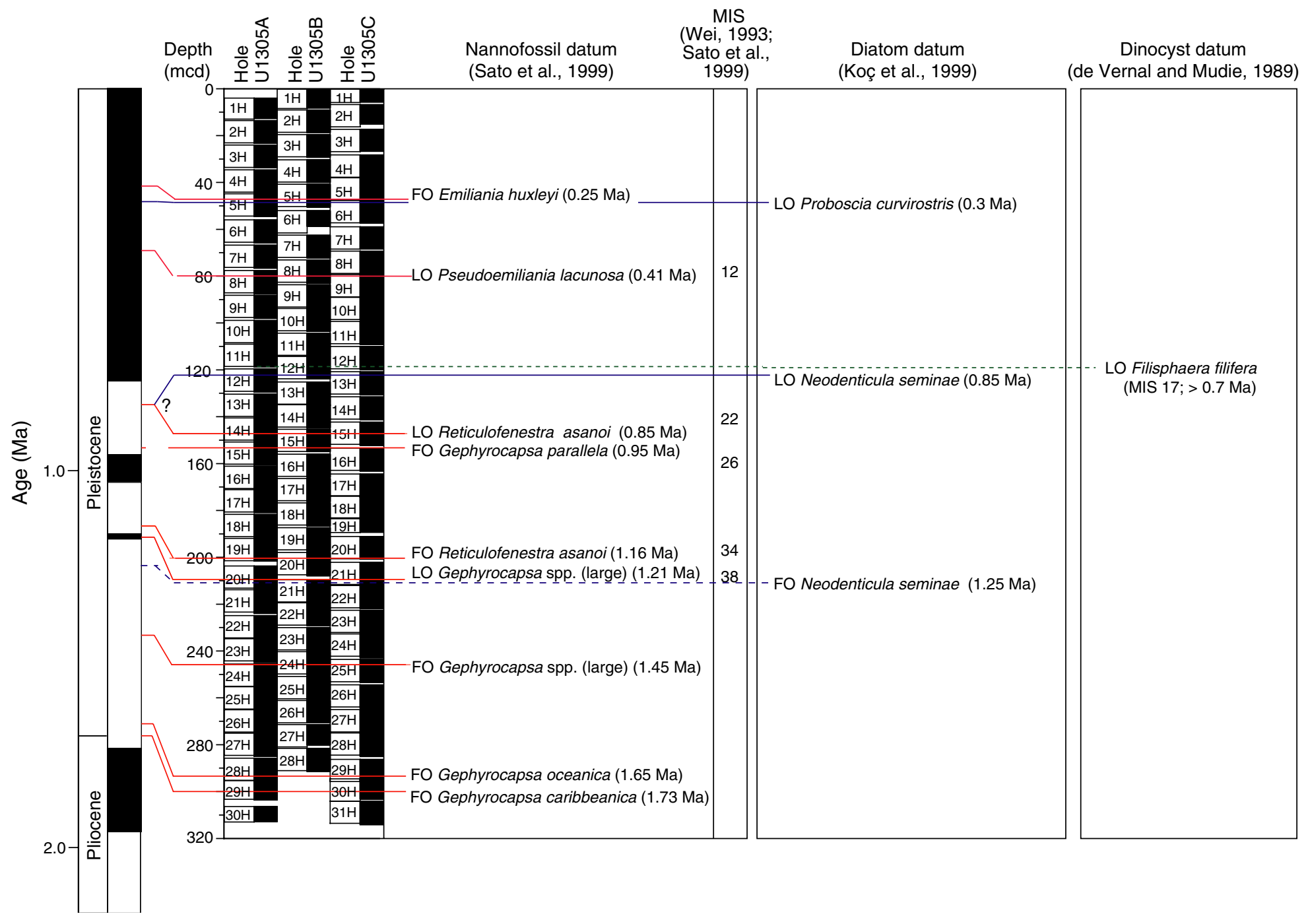


Figure F17. Site U1305 downcore relative abundance of calcareous nannofossils, planktonic foraminifers, diatoms, radiolarians, dinocysts, and pollen. $\times=$ reworked pollens

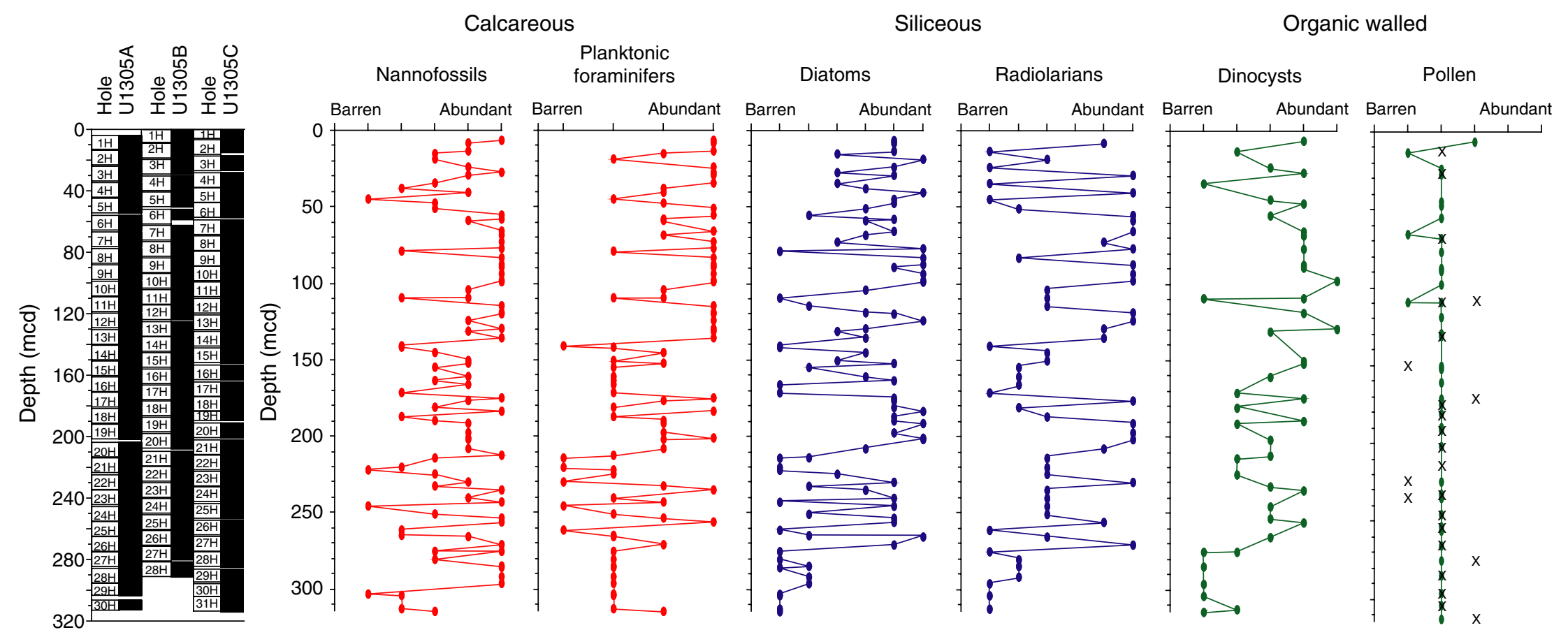


Figure F18. Sites U1305: NRM intensity before and after AF demagnetization (before $=$ black, $10 \mathrm{mT}=\mathrm{blue}, 20$ $\mathrm{mT}=\mathrm{red}$ ) versus depth (mcd). Core recovery is shown in the left panel.

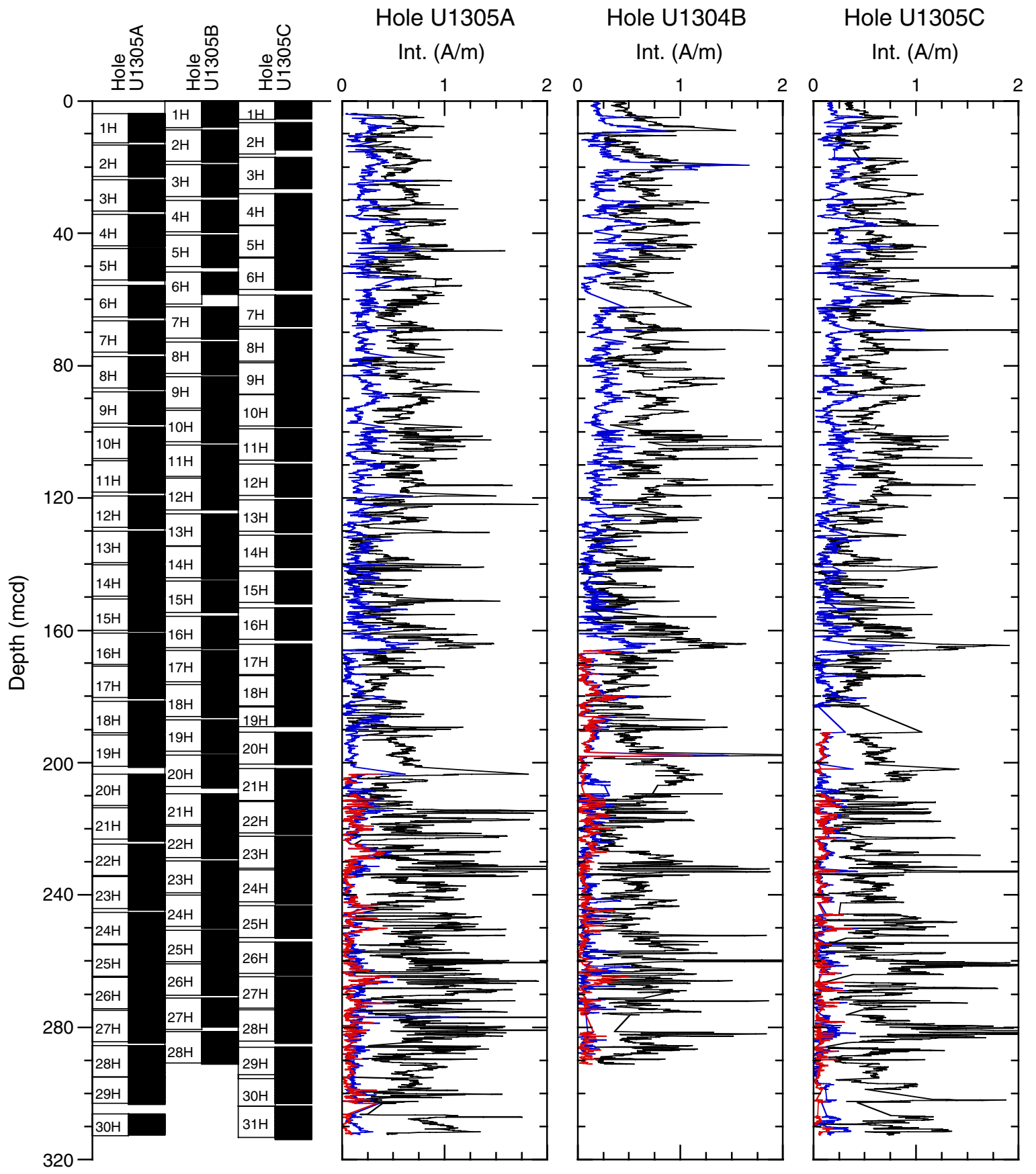


Figure F19. Sites U1305: Inclination after peak AF demagnetization $(10 \mathrm{mT}=$ black, $15 \mathrm{mT}=$ blue, $20 \mathrm{mT}=$ red) versus depth (mcd). Core recovery is shown in the left panel.

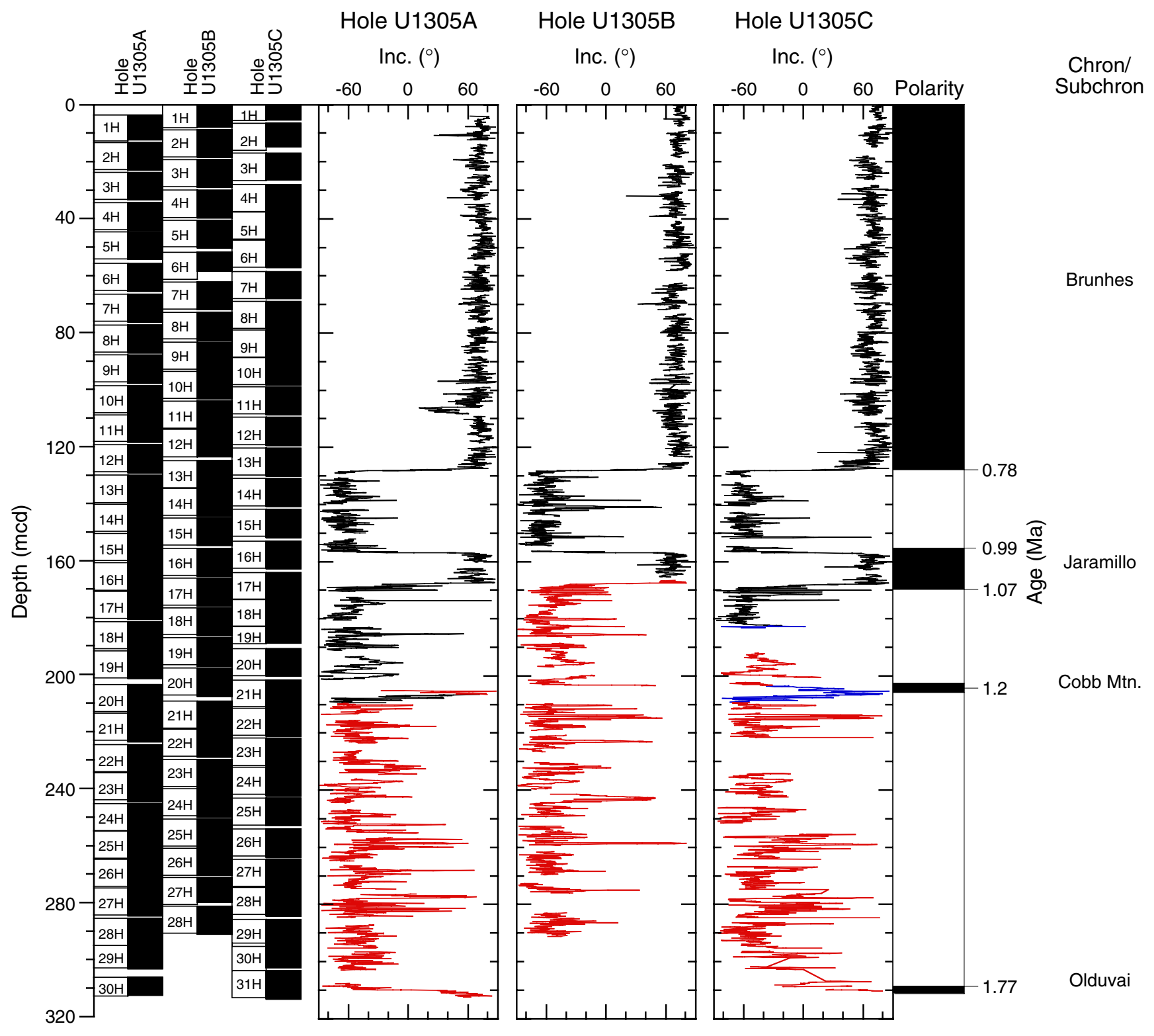


Figure F20. Site U1305 declination after peak AF demagnetization $(10 \mathrm{mT}=$ light blue, $15 \mathrm{mT}=$ dark blue, 20 $\mathrm{mT}=$ red) and after tensor tool correction (black) versus depth (mcd). Core recovery is shown in the left panel.

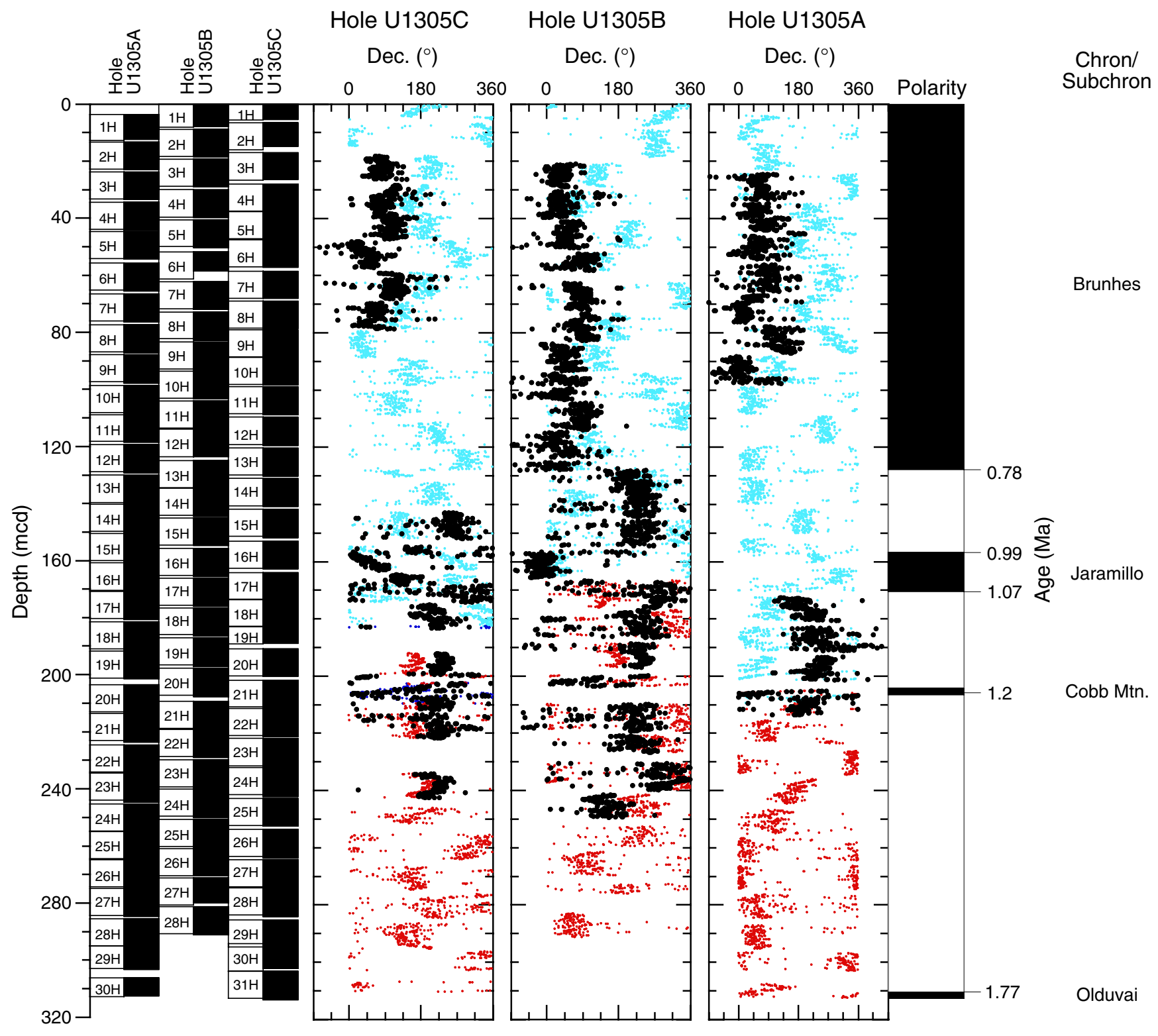


Figure F21. Lower panel: Magnetic susceptibility versus mcd for each hole drilled at Site U1305. Upper panel: Composite magnetic susceptibility record indicating which hole was used to form the splice. A. 0-40 mcd. (Continued on next seven pages.)
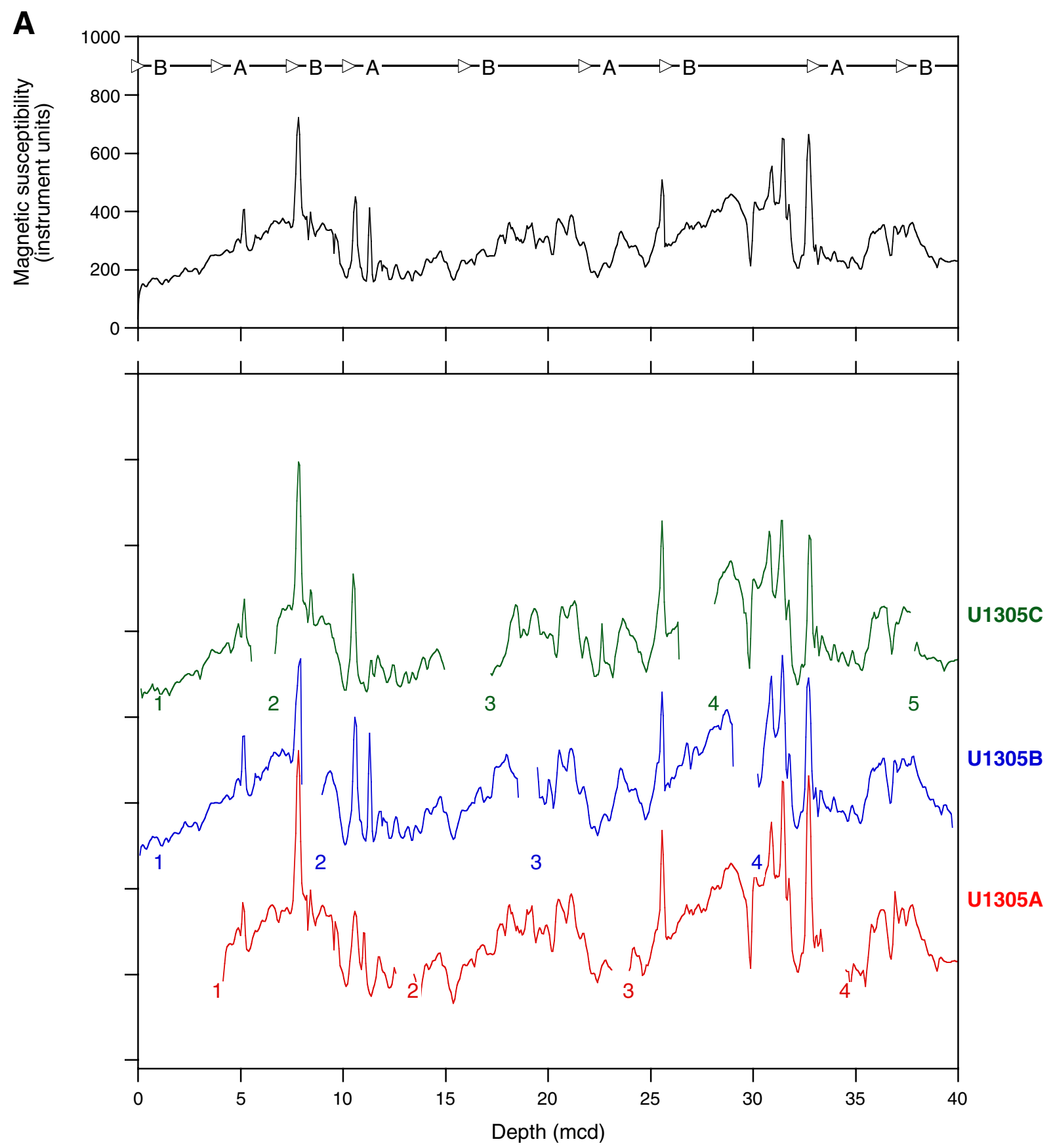
Figure F21 (continued). B. $40-80 \mathrm{mcd}$.
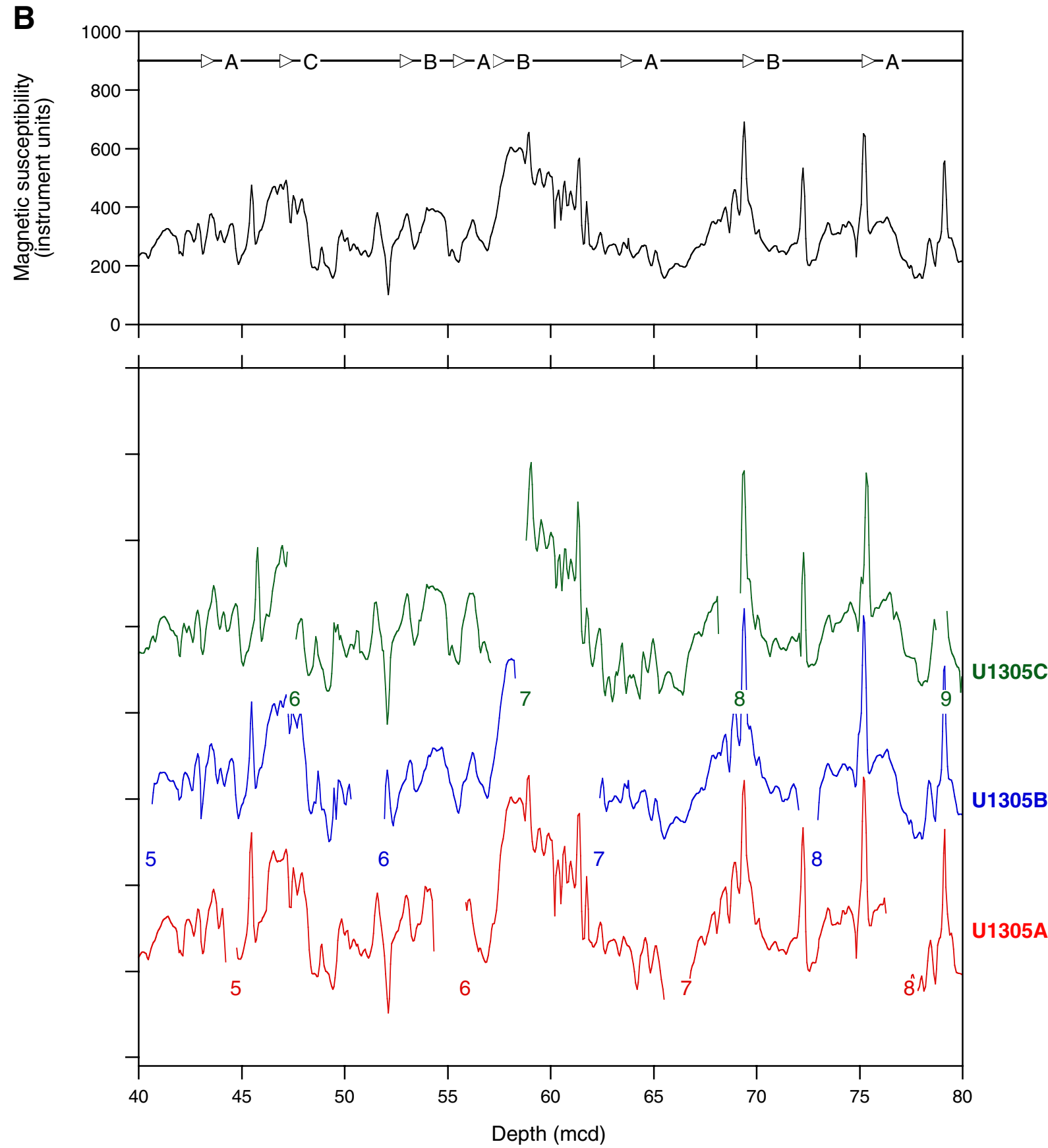
Figure F21 (continued). C. 80-120 mcd.
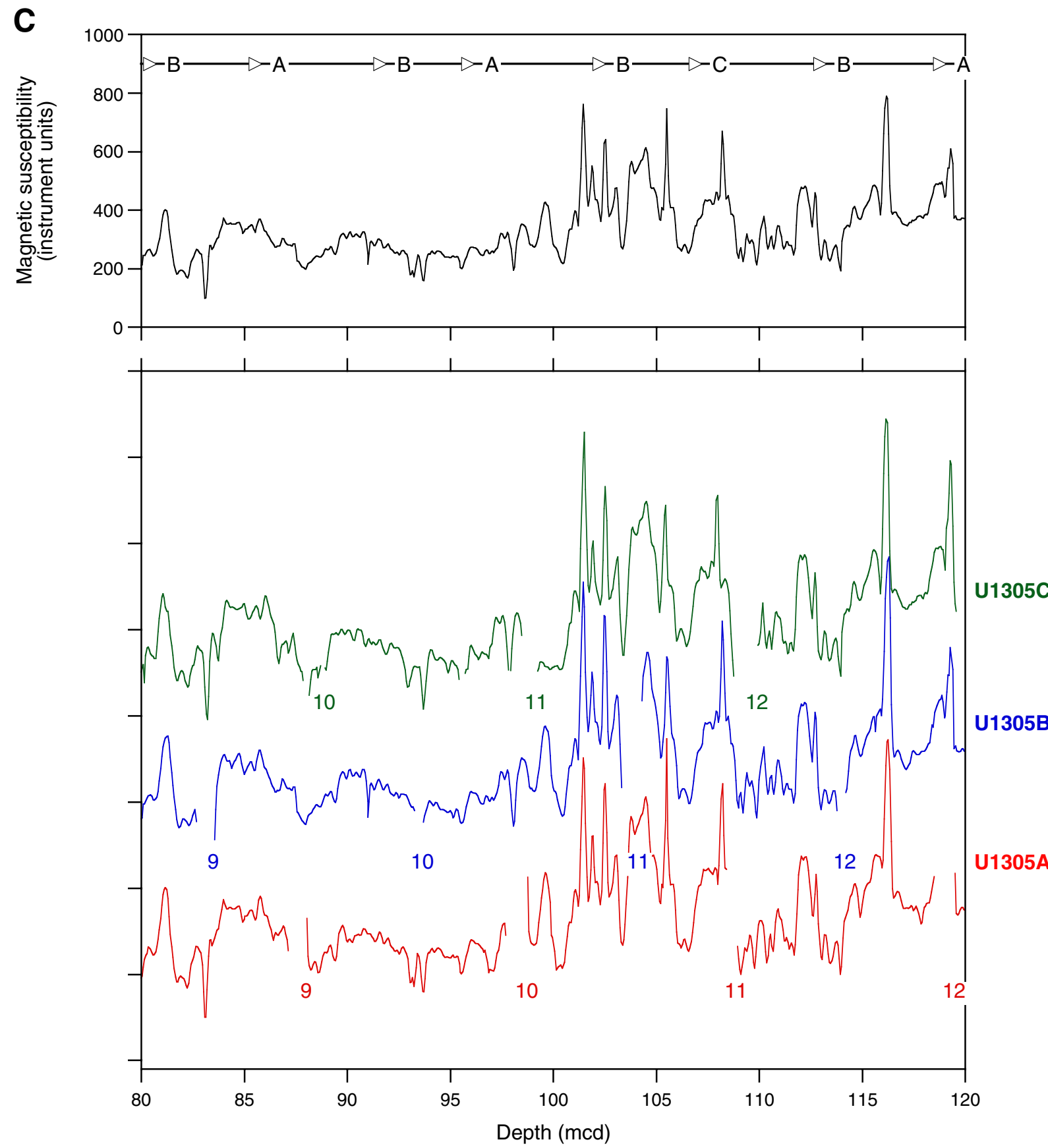
Figure F21 (continued). D. 120-160 mcd.
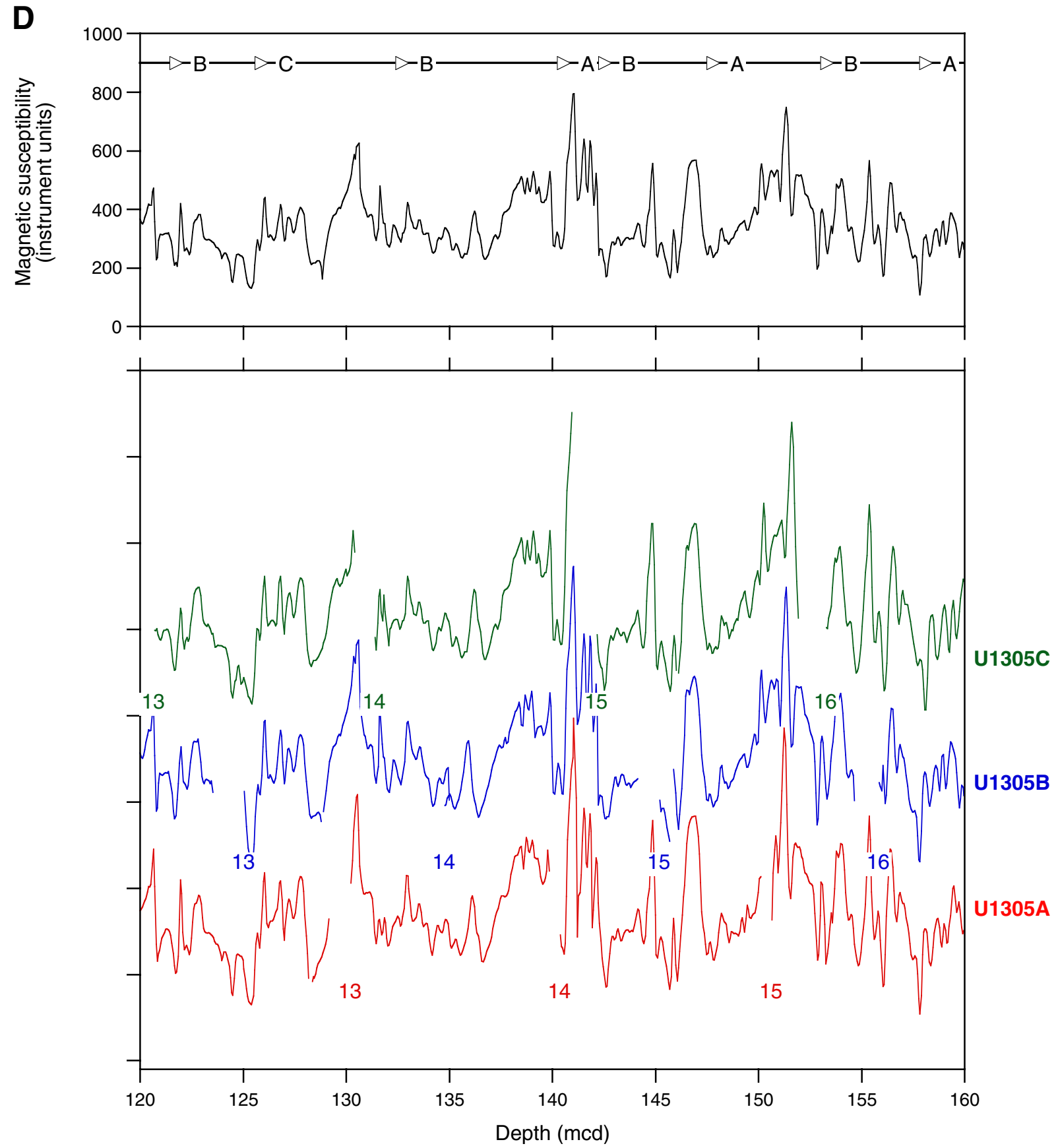
Figure F21 (continued). E. 160-200 mcd.
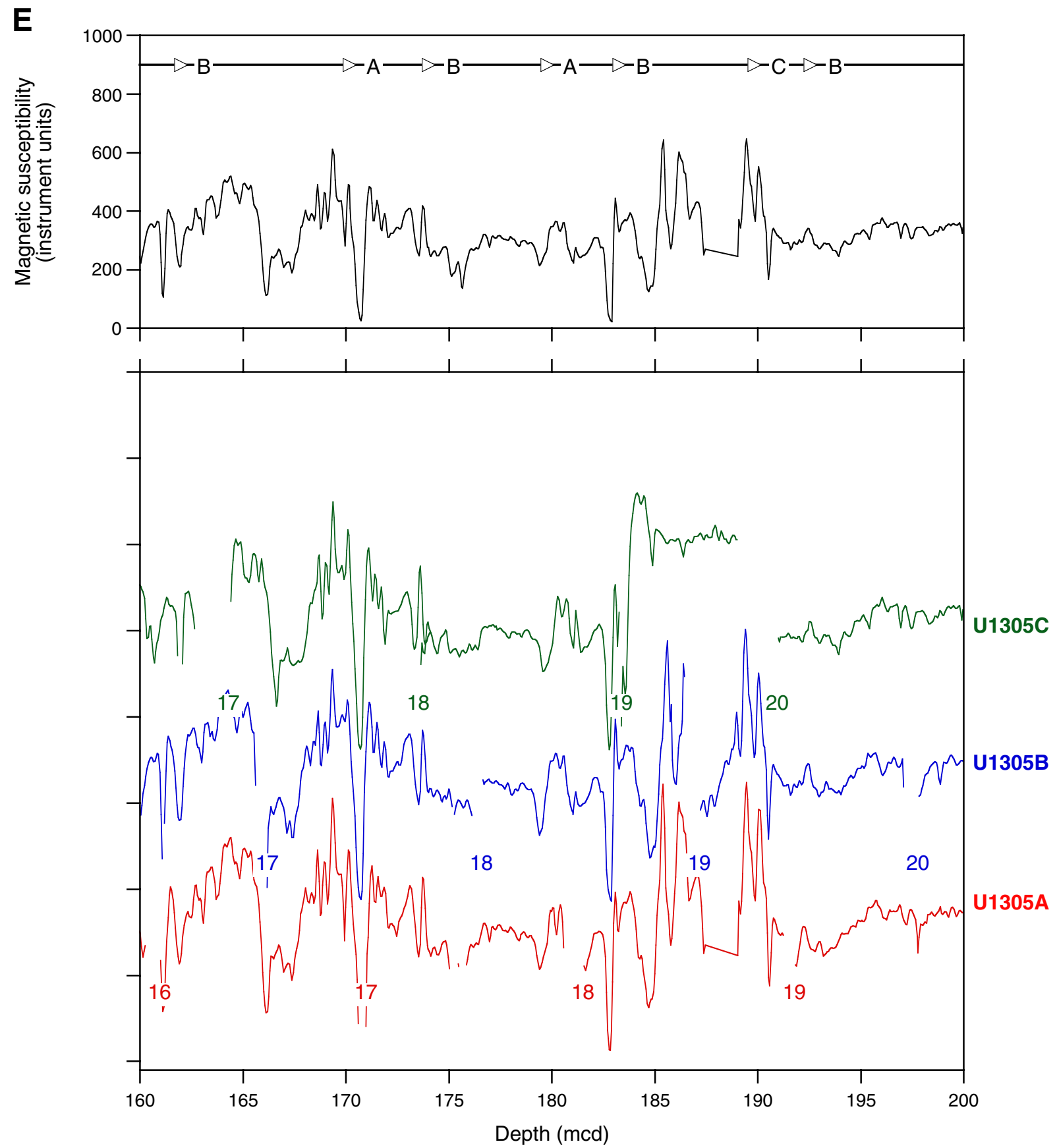
Figure F21 (continued). F. 200-240 mcd.

F
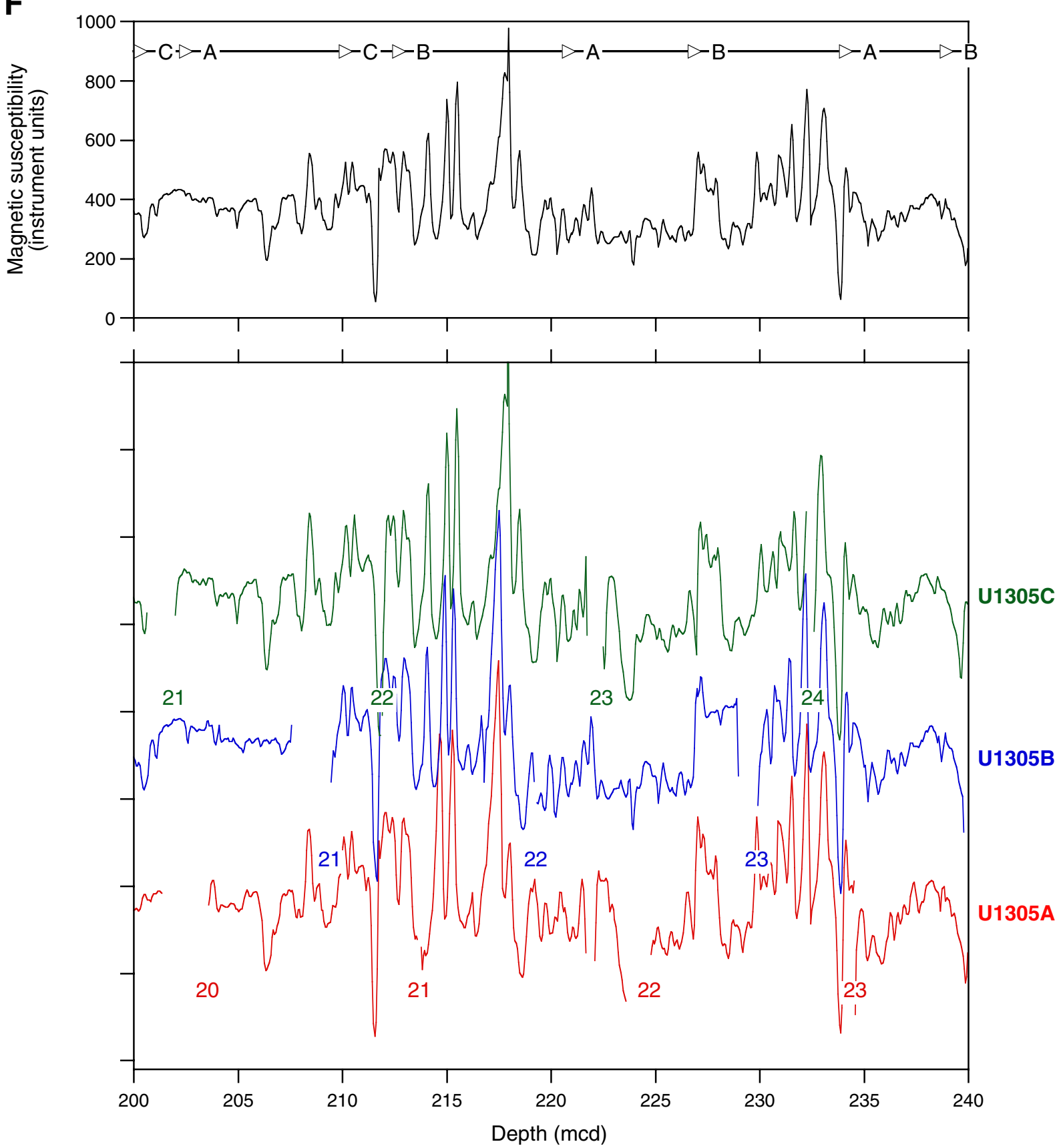
Figure F21 (continued). G. 240-280 mcd.
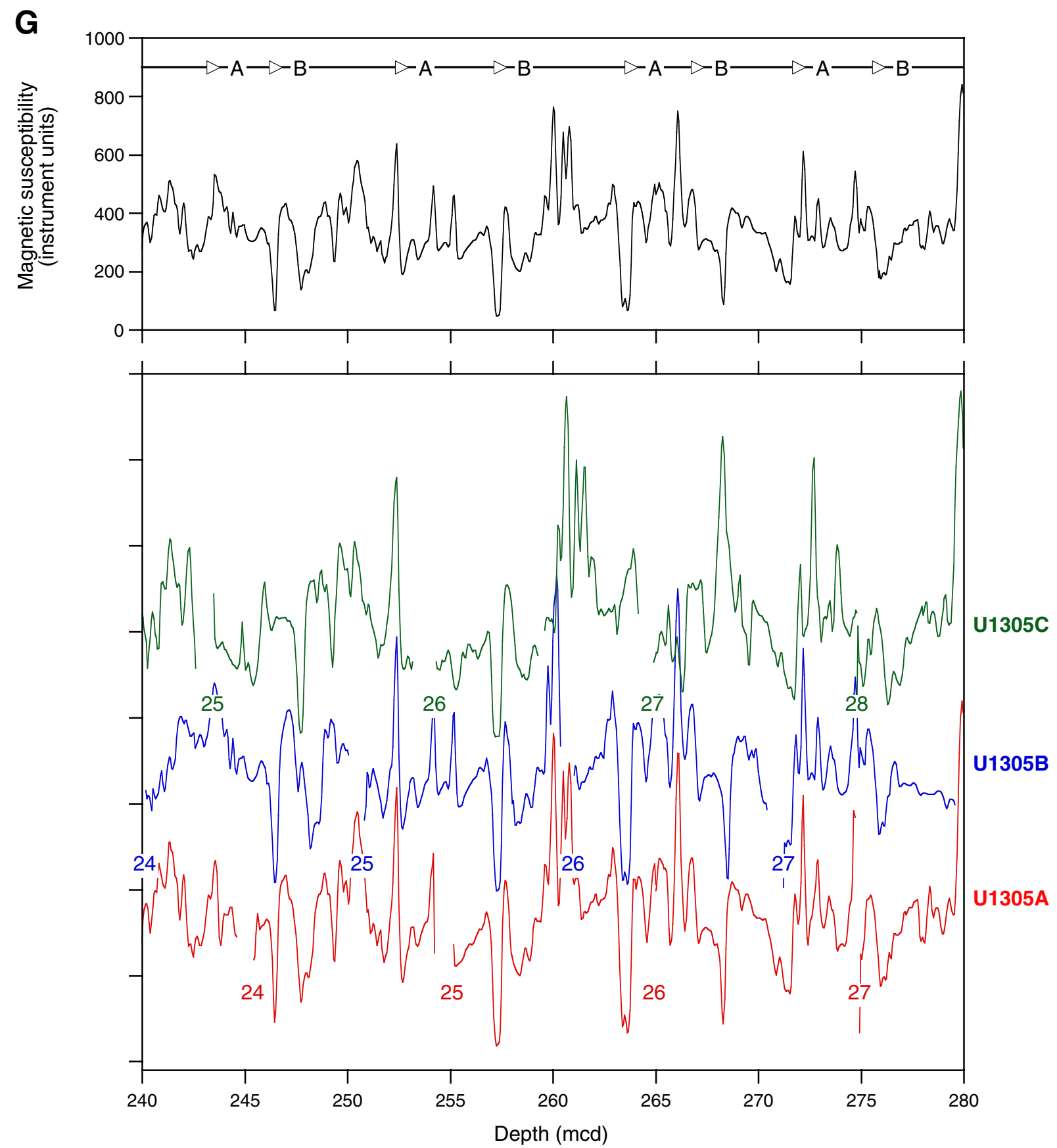
Figure F21 (continued). H. 280-320 mcd.

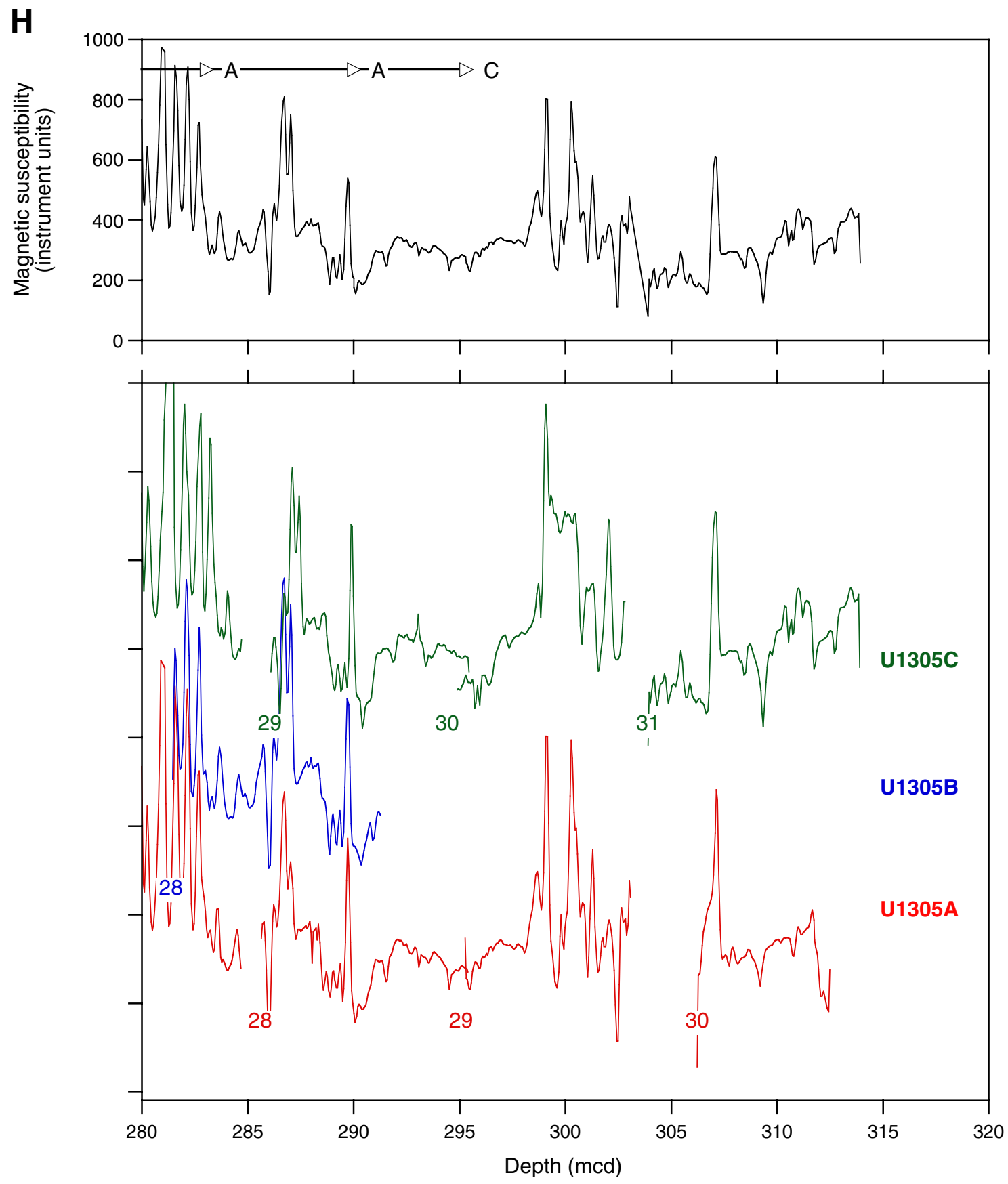


Figure F22. Meters composite depth versus meters below seafloor (mbsf) for tops of cores at Site U1305. The growth factor $(\mathrm{GF}=1.10)$ is the slope of the regression line. On average, the mcd of the spliced section is $10 \%$ greater than mbsf.

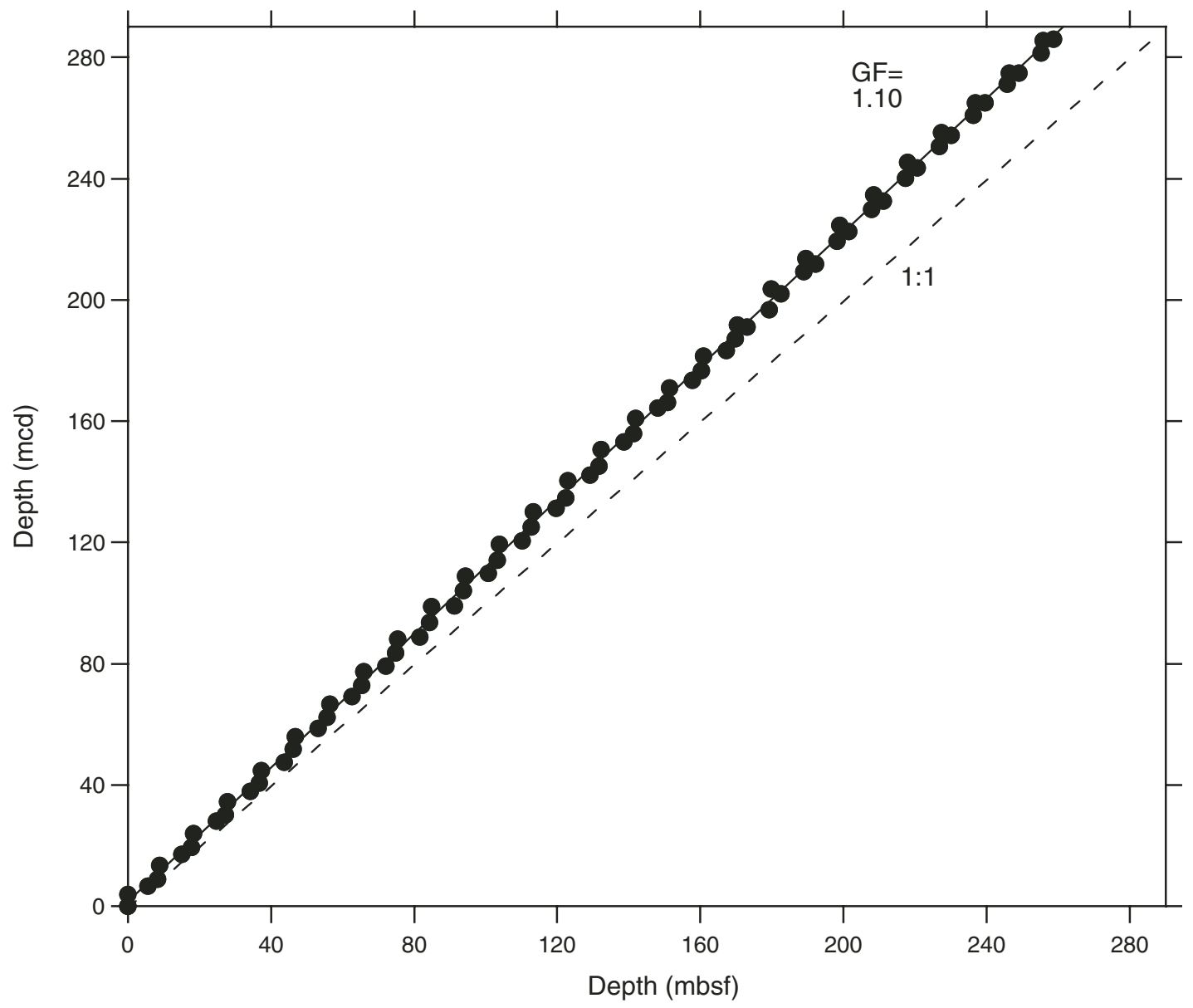


Figure F23. A. Age versus depth (mcd) for biostratigraphic and paleomagnetic datums for Site U1305. A mean sedimentation rate of $17.6 \mathrm{~cm} / \mathrm{k} . \mathrm{y}$. was calculated by linear regression. B. Same datums shown in A with the interval sedimentation rates derived from the paleomagnetic datums only.

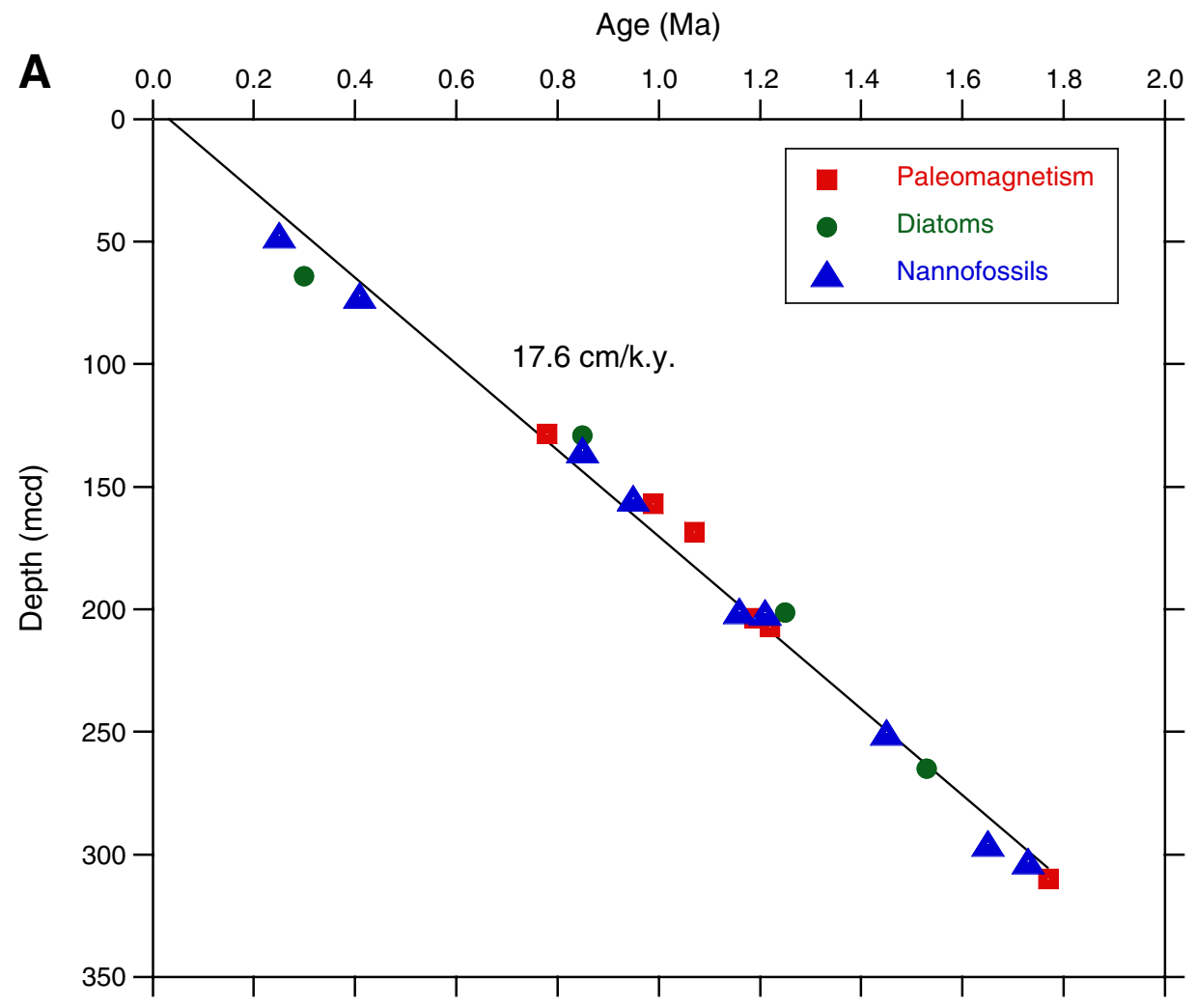

B

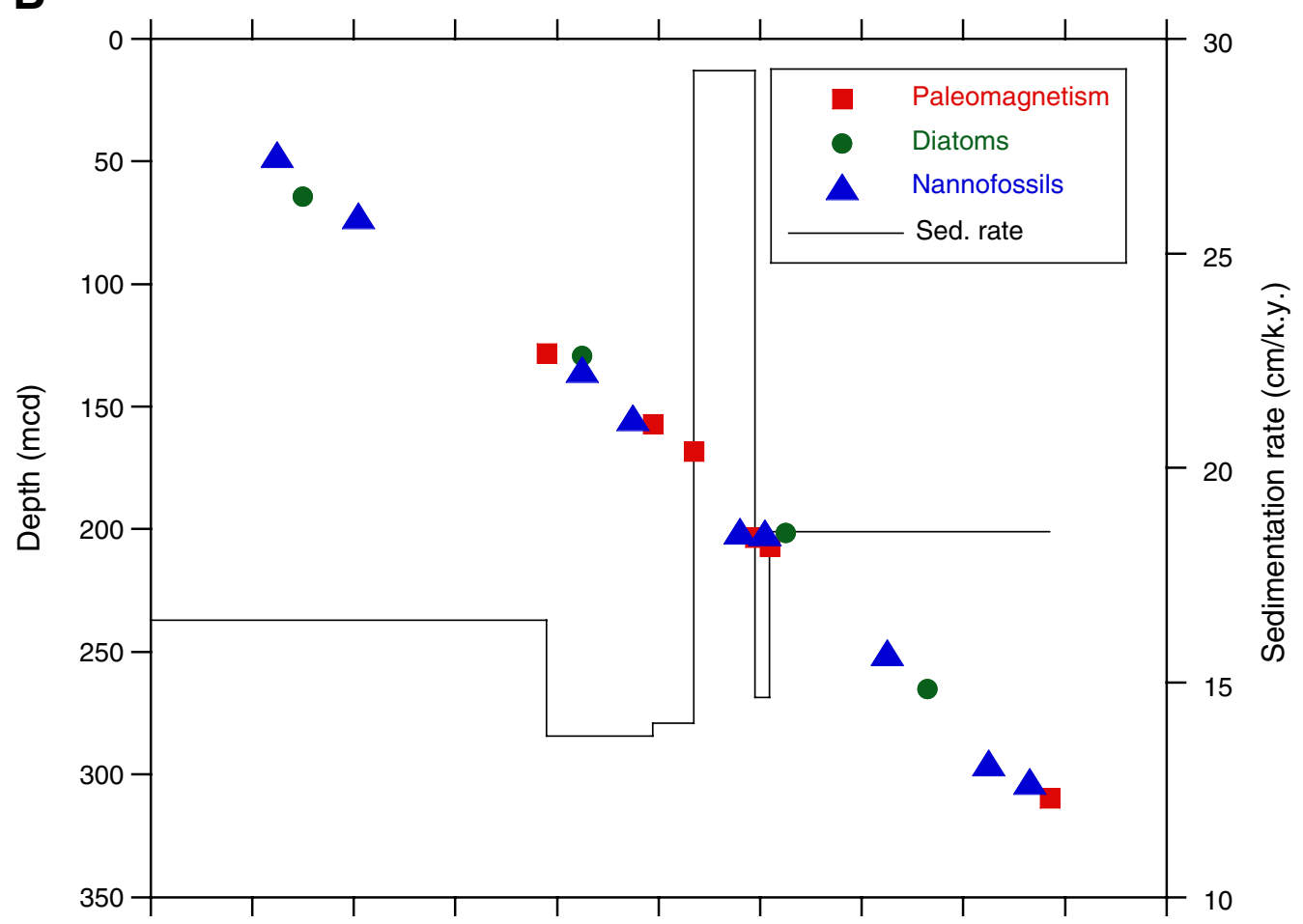


Figure F24. Headspace methane concentrations for Hole U1305A.

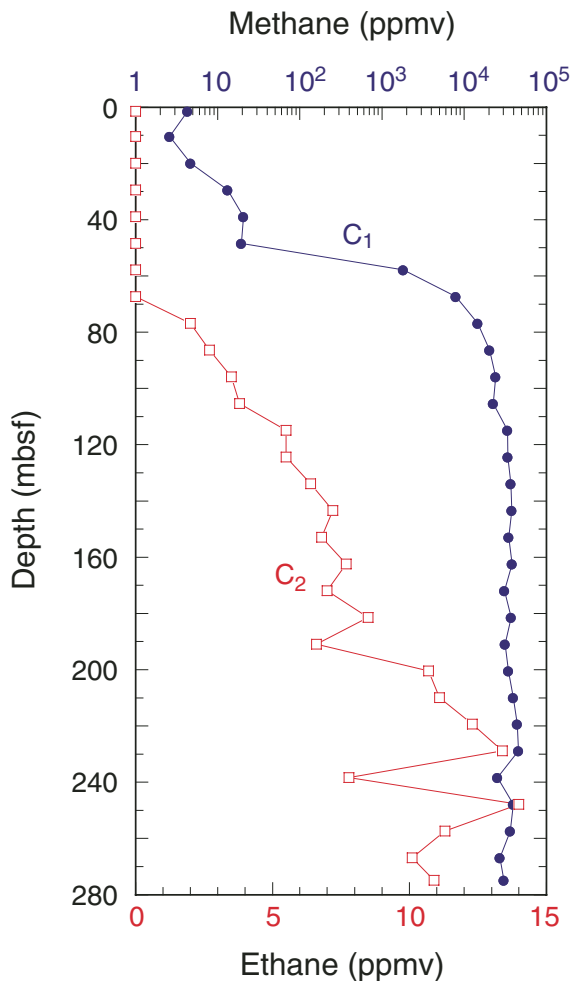


Figure F25. Site U1305 carbonate contents and elemental compositions. A. Calcium carbonate. B. Total organic carbon (TOC). C. Elemental nitrogen. D. Organic C/N ratio.

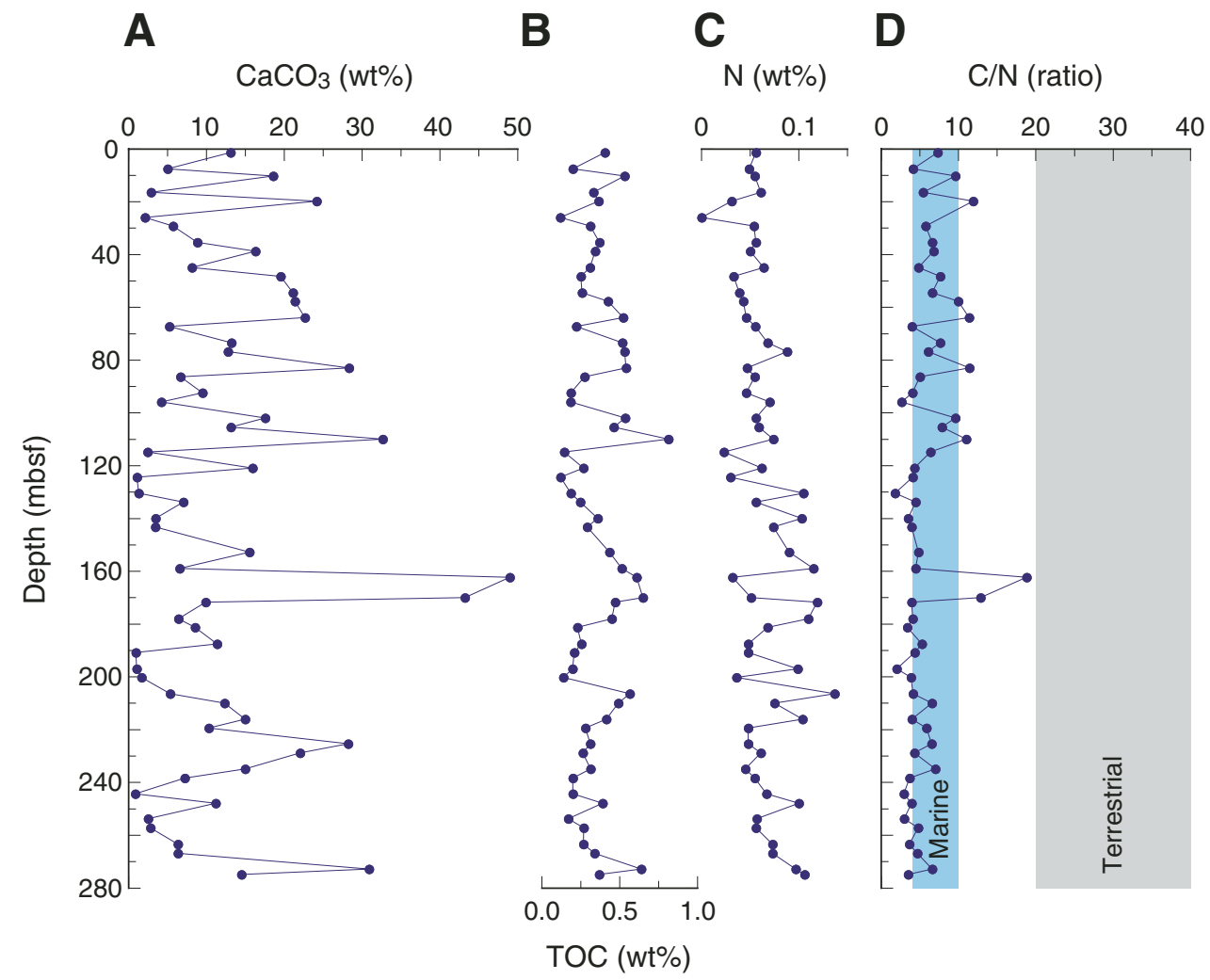


Figure F26. Profiles of chemical constituents in interstitial waters from Hole U1305A. A. Chlorinity. B. Sodium. C. pH. D. Boron. E. Alkalinity. F. Sulfate. G. Ammonium. H. Dissolved silica. I. Calcium. J. Strontium and Sr/Ca ratio. K. Lithium and Li/Ca ratio. L. Barium. M. Magnesium. N. Potassium. O. Manganese. P. Iron.
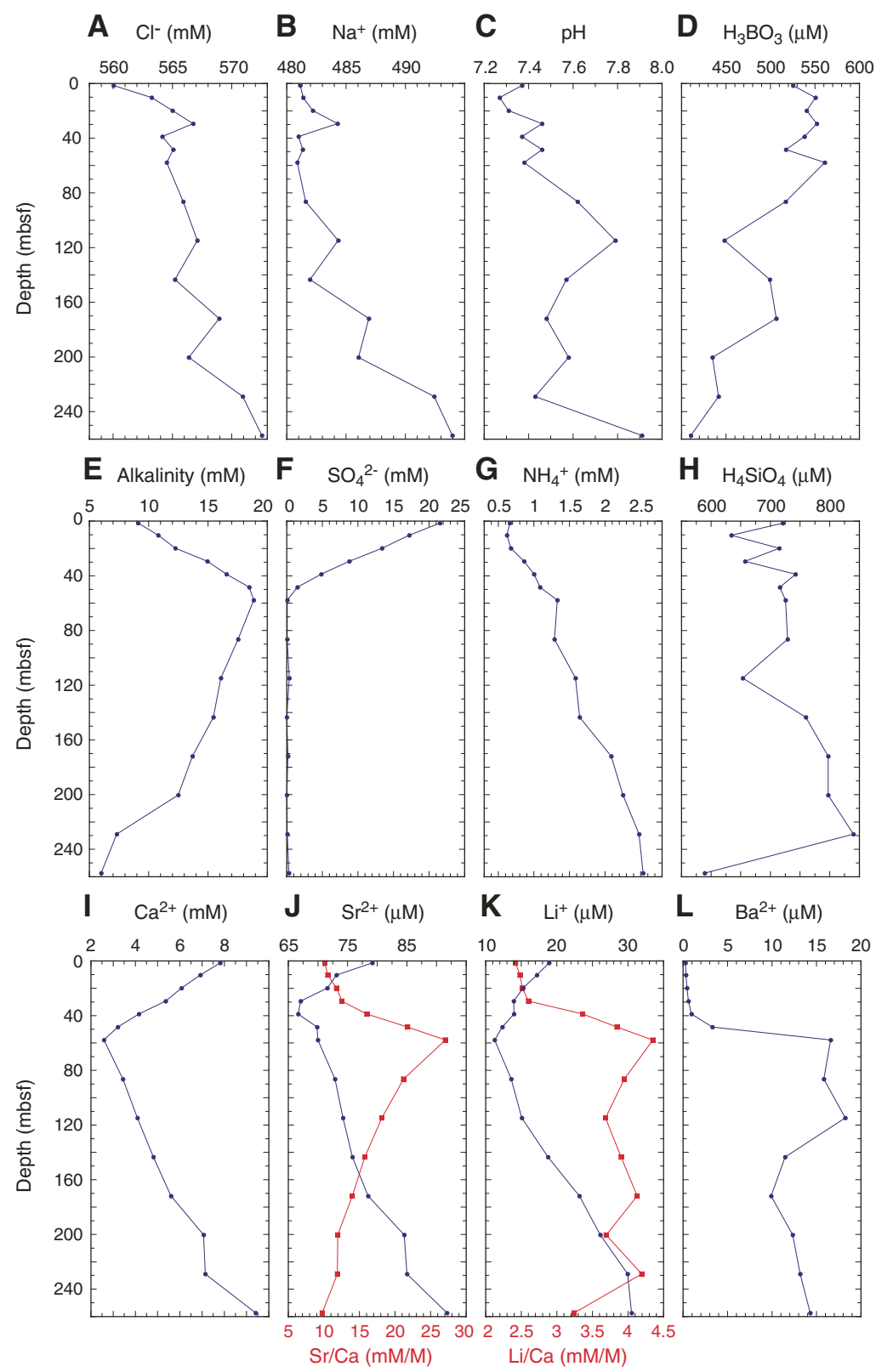

L $\quad \mathrm{Ba}^{2+}(\mu \mathrm{M})$
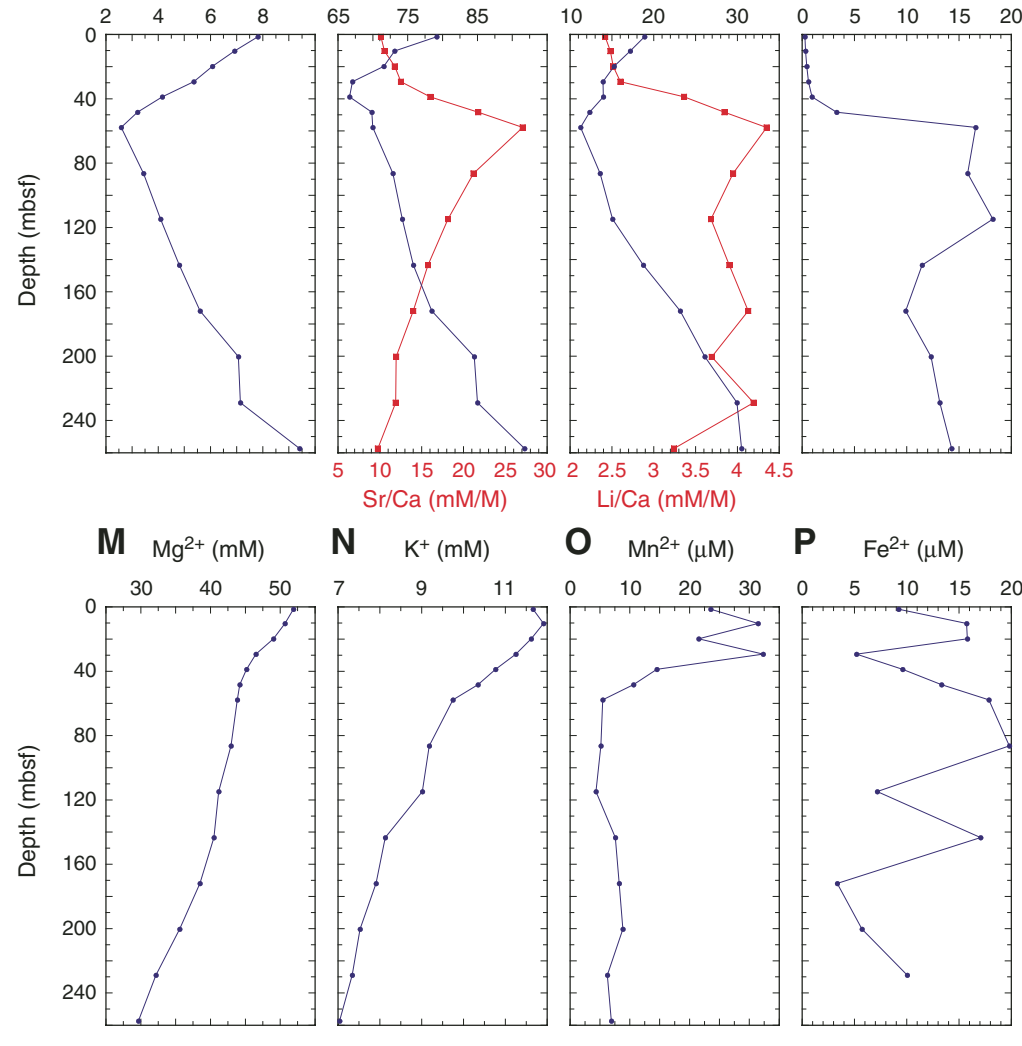

O $\mathrm{Mn}^{2+}(\mu \mathrm{M})$

P $\mathrm{Fe}^{2+}(\mu \mathrm{M})$
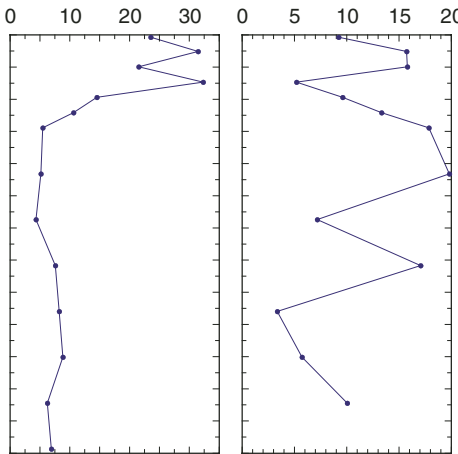
Figure F27. Profiles of headspace methane and interstitial water sulfate concentrations for Hole U1305A.

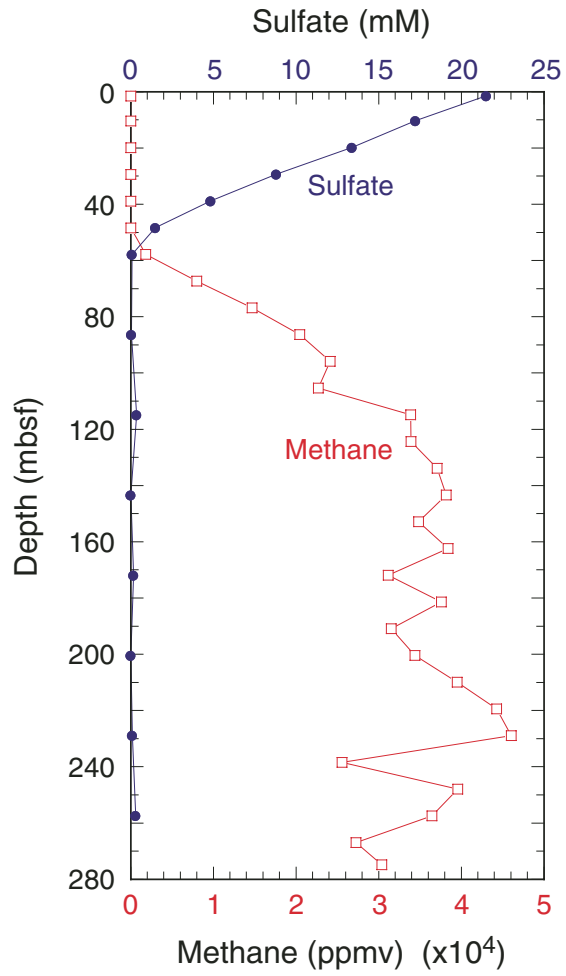


Figure F28. Site U1305 magnetic susceptibility (MS) records. Core recovery columns are represented on the left side. Black = multisensor track record, red = magnetic susceptibility core logger (MSCL) record.

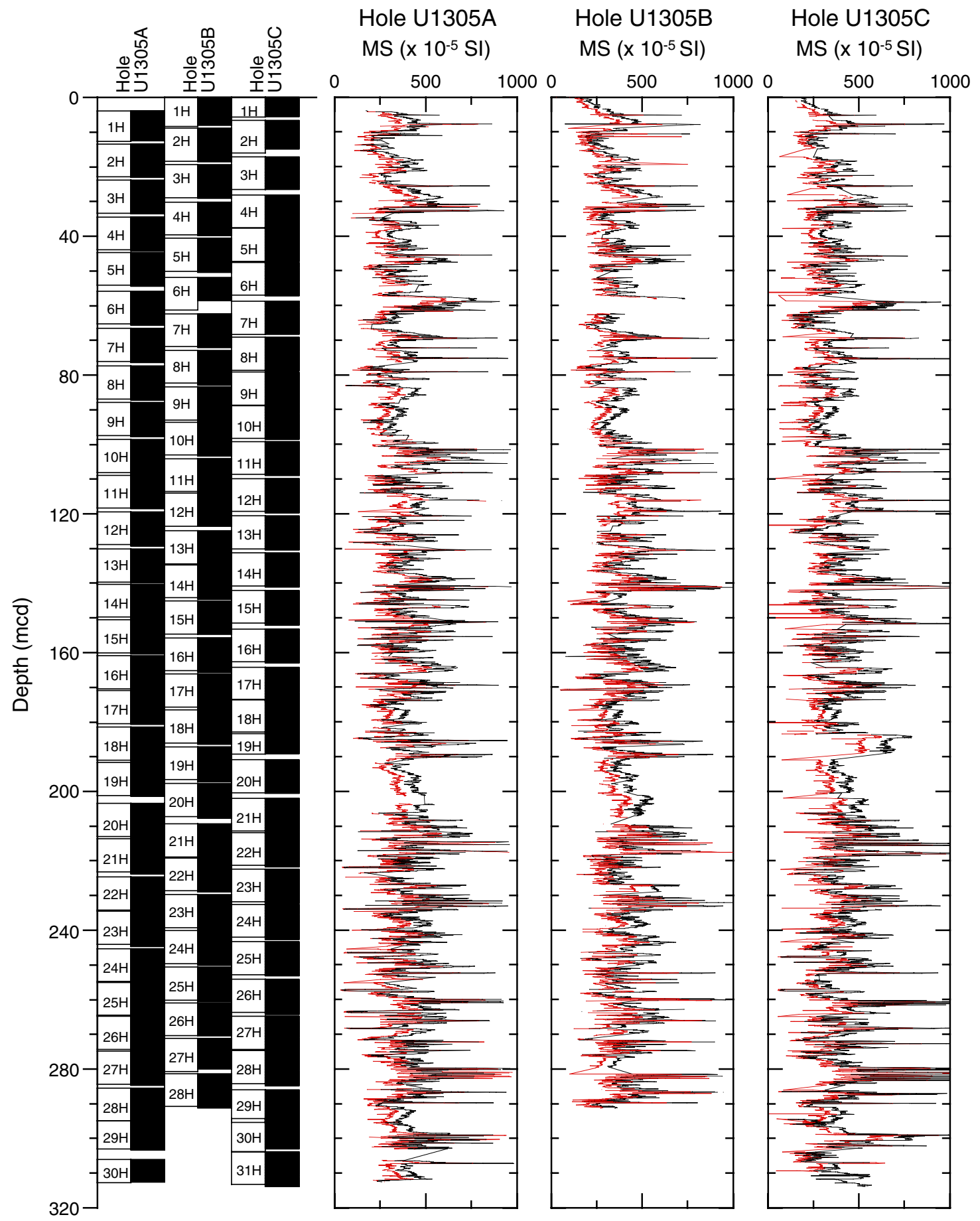


Figure F29. Combined gamma ray attenuation density measurements from the multisensor track and bulk density from discrete measurements (red circles), Site U1305.

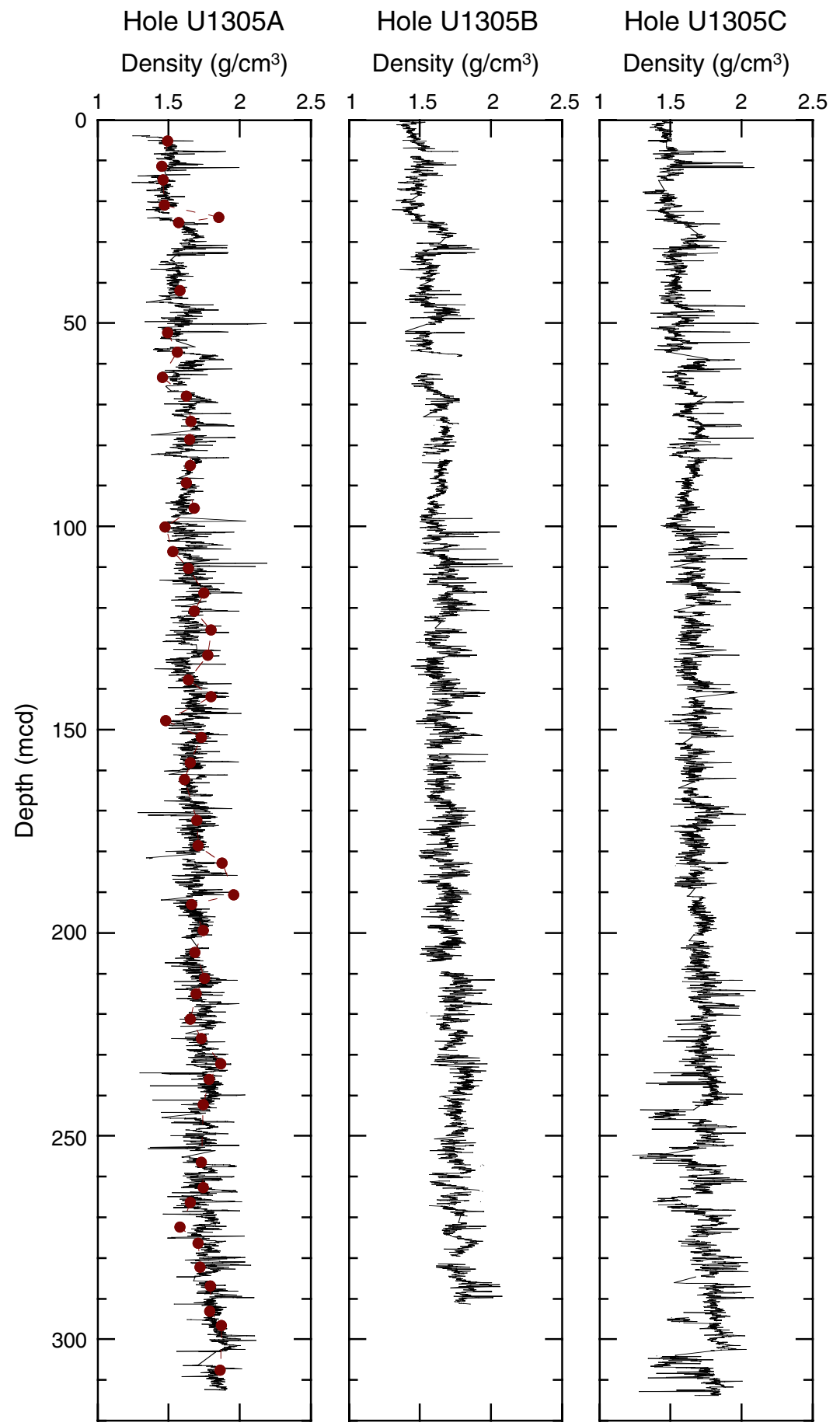


Figure F30. Natural gamma ray (NGR) counts from the multisensor track (MST), Site U1305.

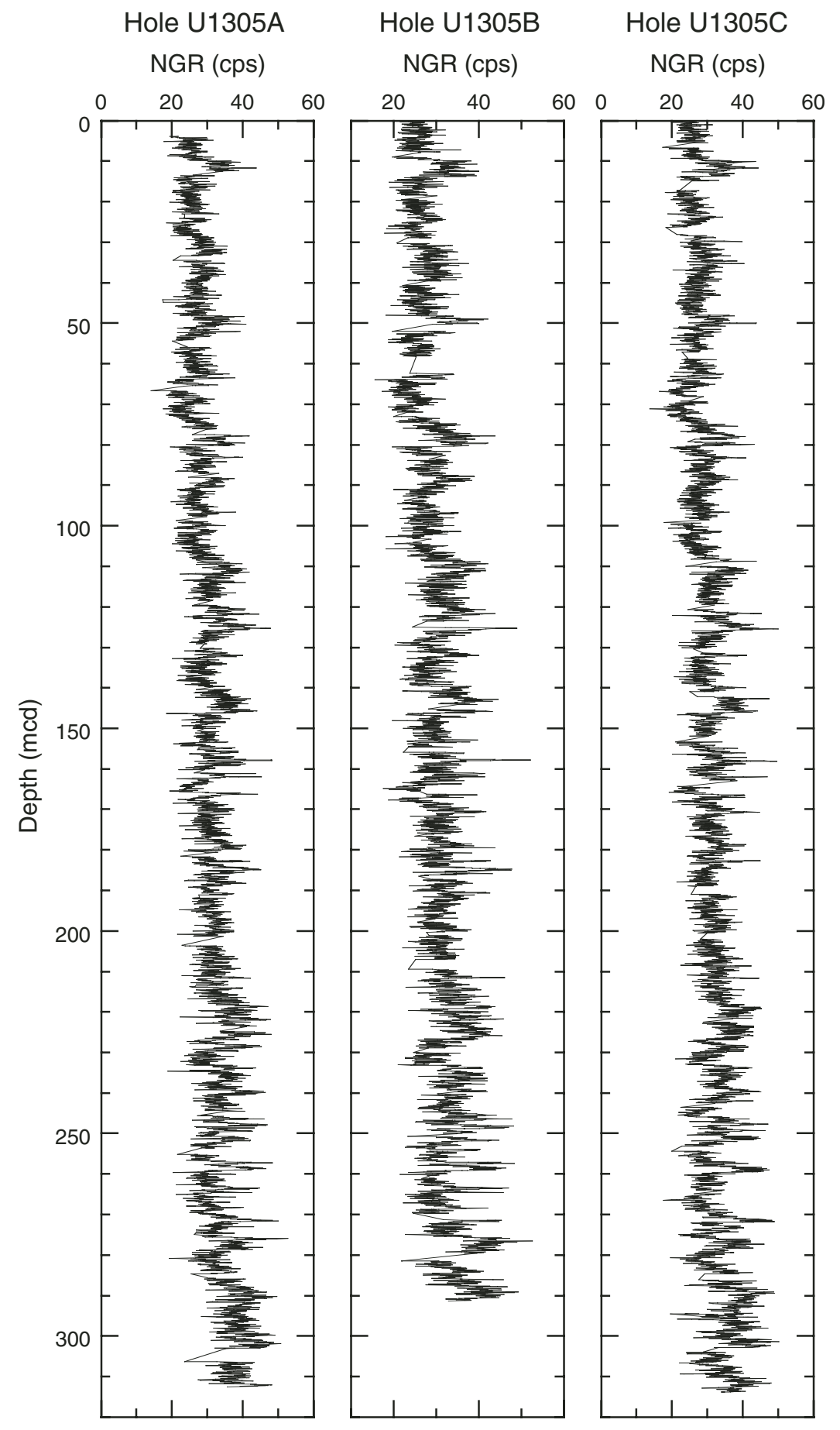


Figure F31. Downcore $P$-wave velocity records, Site U1305. Red circles = PWL3 discrete measurements.

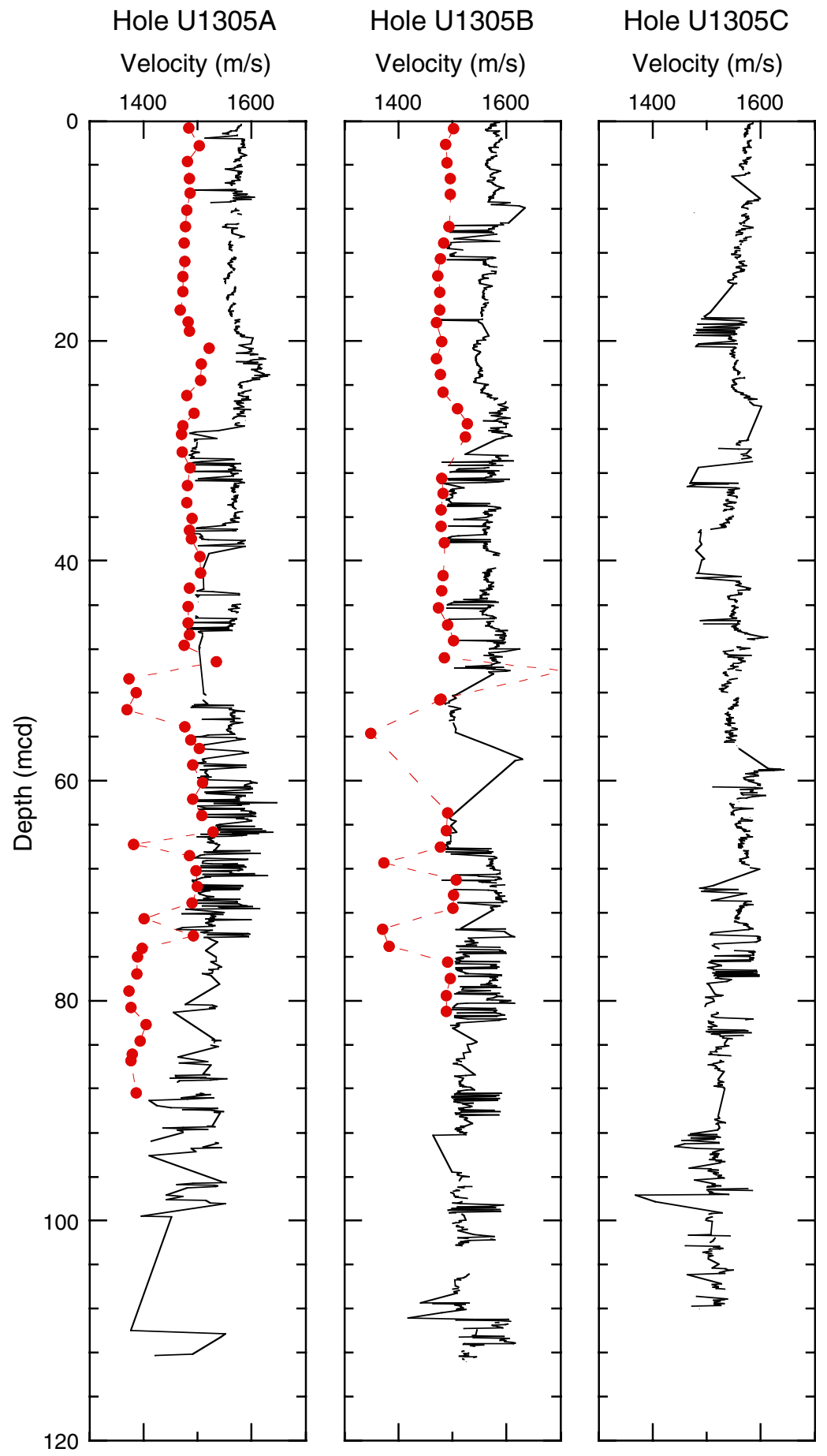


Figure F32. Downcore gamma ray attenuation-derived porosity calculations and discrete porosity measurements (red circles), Site U1305.

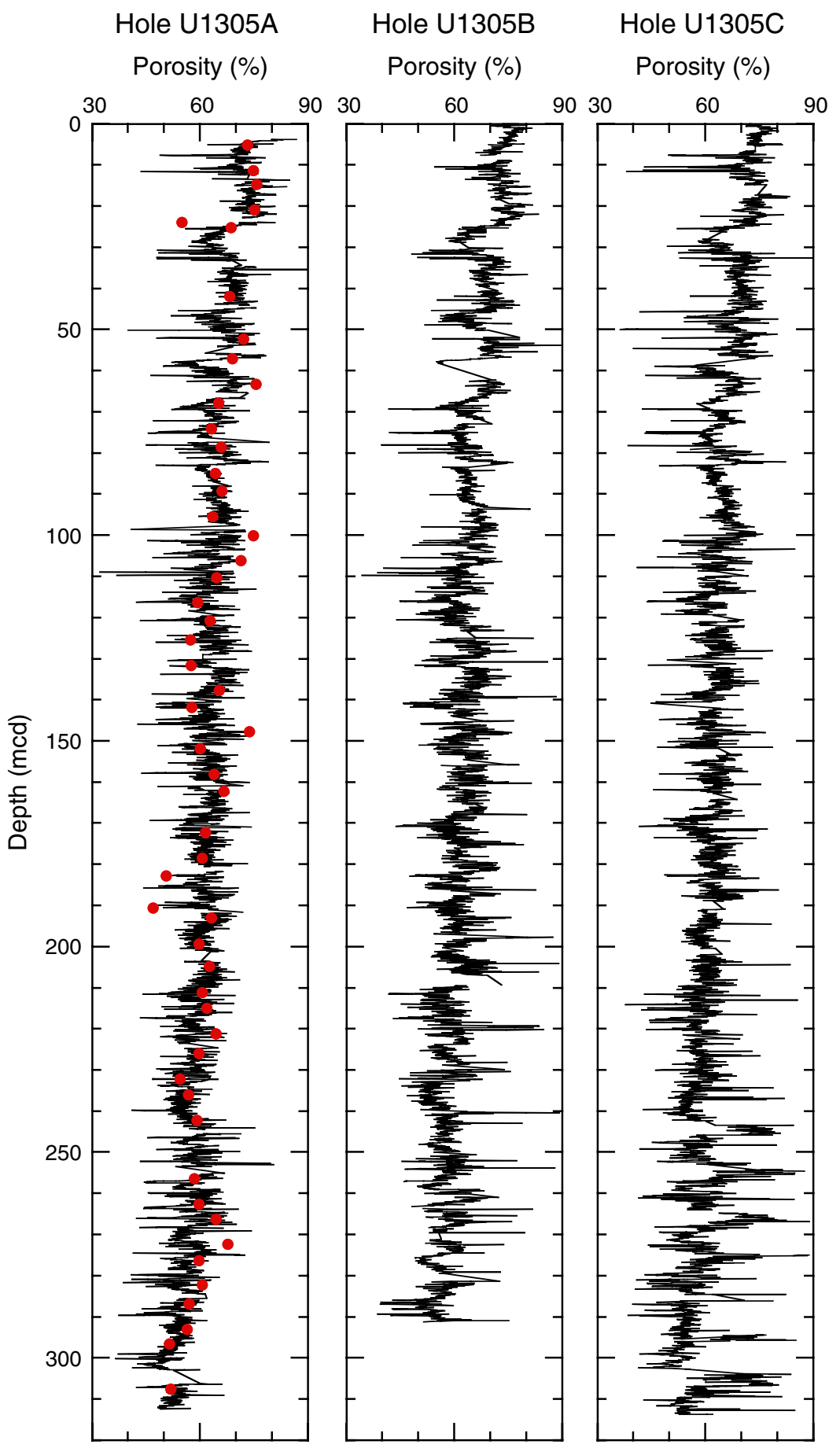


Figure F33. Combined plots of the spliced records of "fast track" magnetic susceptibility (MS) and multisensor track-derived MS, gamma ray attenuation (GRA) density, and natural gamma ray (NGR), Site U1305. A. 0-100 mcd. (Continued on next two pages.)

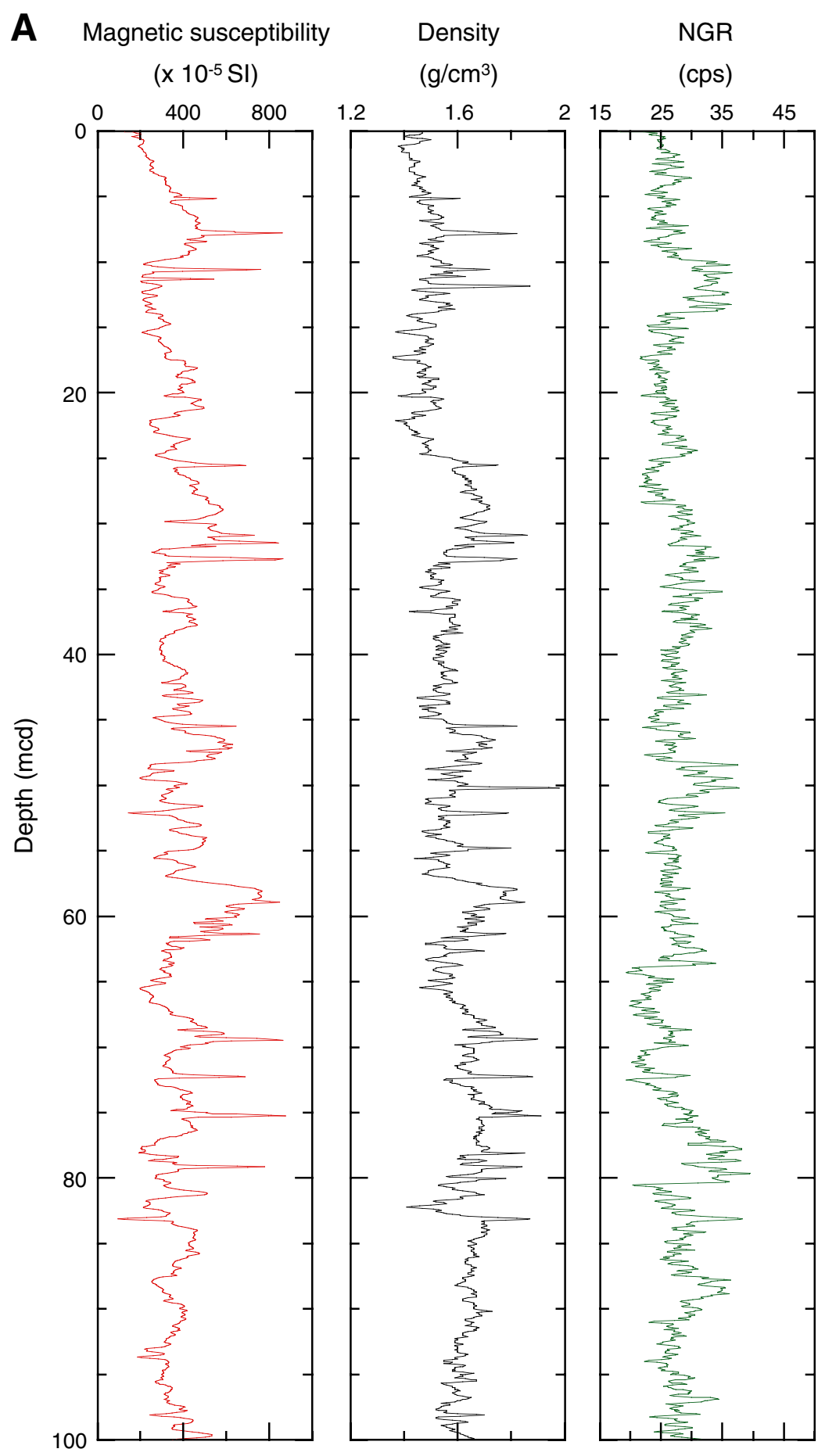


Figure F33 (continued). B. 100-200 mcd.

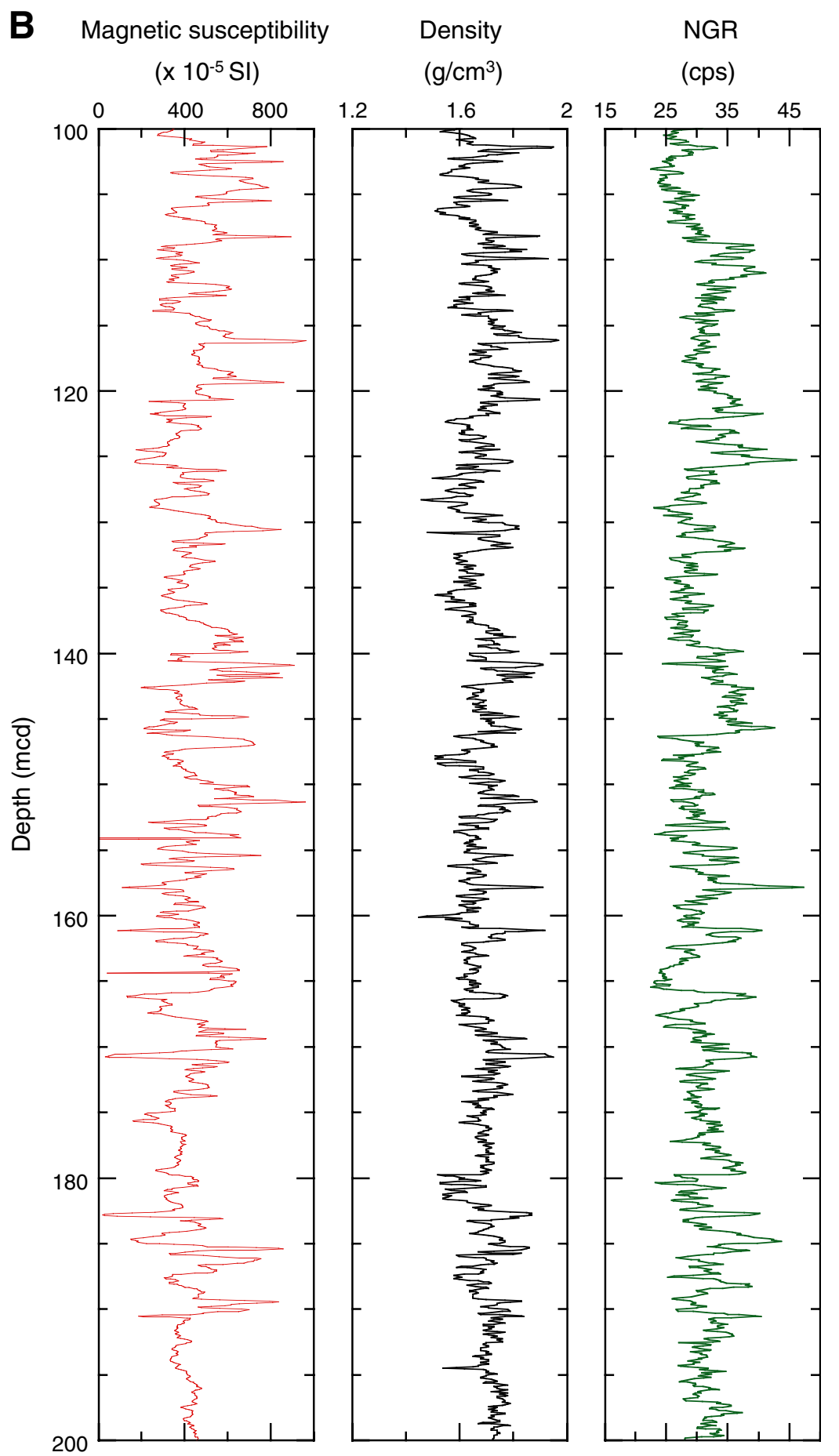


Figure F33 (continued). C. 200-320 mcd.

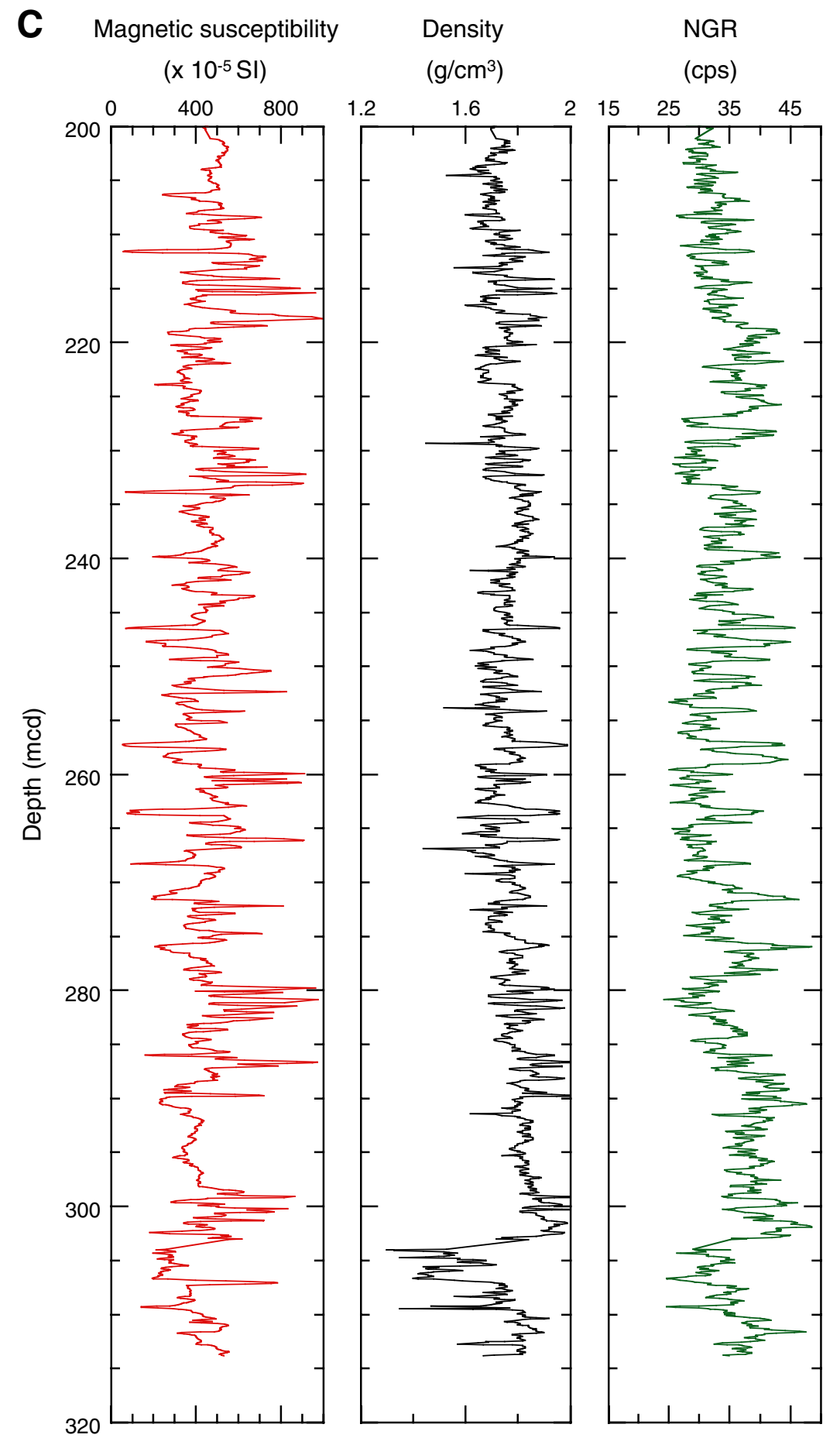


Figure F34. Details of the logging tool string deployed in Hole U1305C. Triple combo = triple combination tool string.

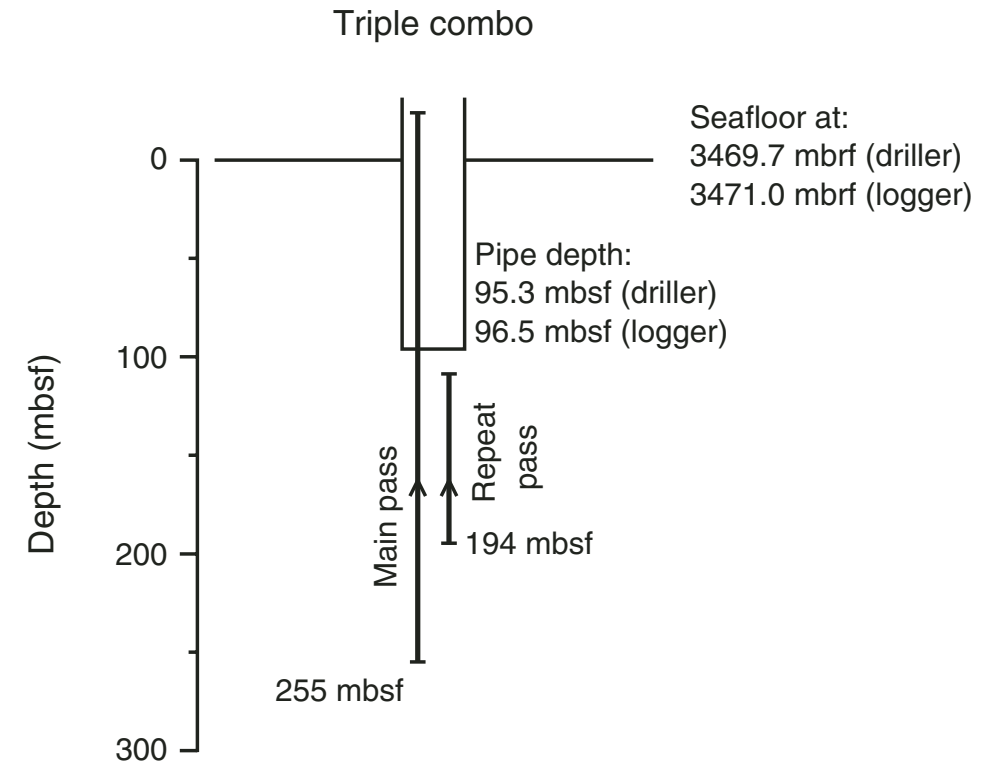


Figure F35. Caliper, main, and repeat-pass gamma ray and core recovery records, Hole U1305C. gAPI = American Petroleum Institute gamma ray units.

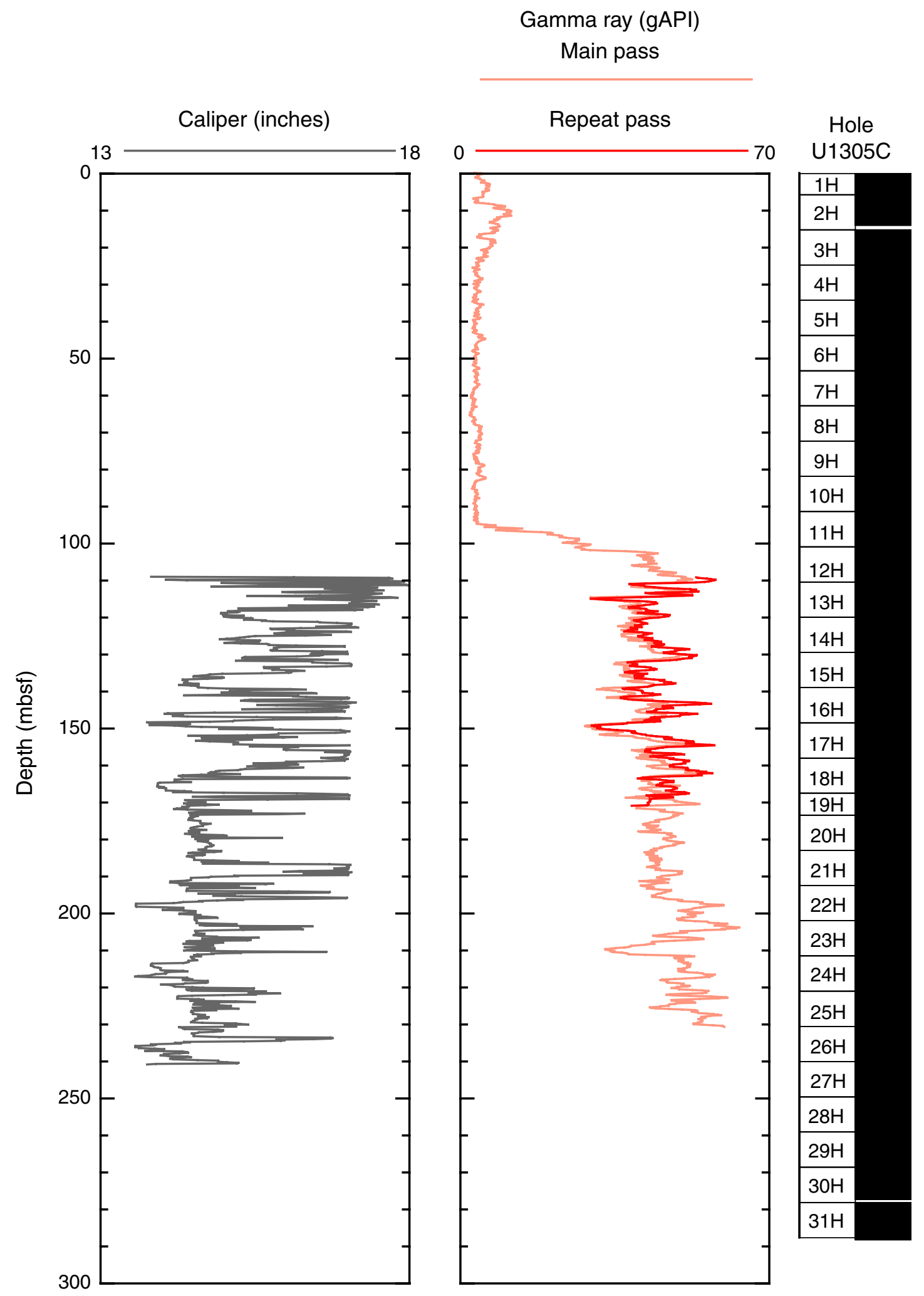


Figure F36. Caliper, density, porosity, electrical resistivity, and photoelectric effect (PEF) data for the 95-250 mbsf interval, Hole U1305C.

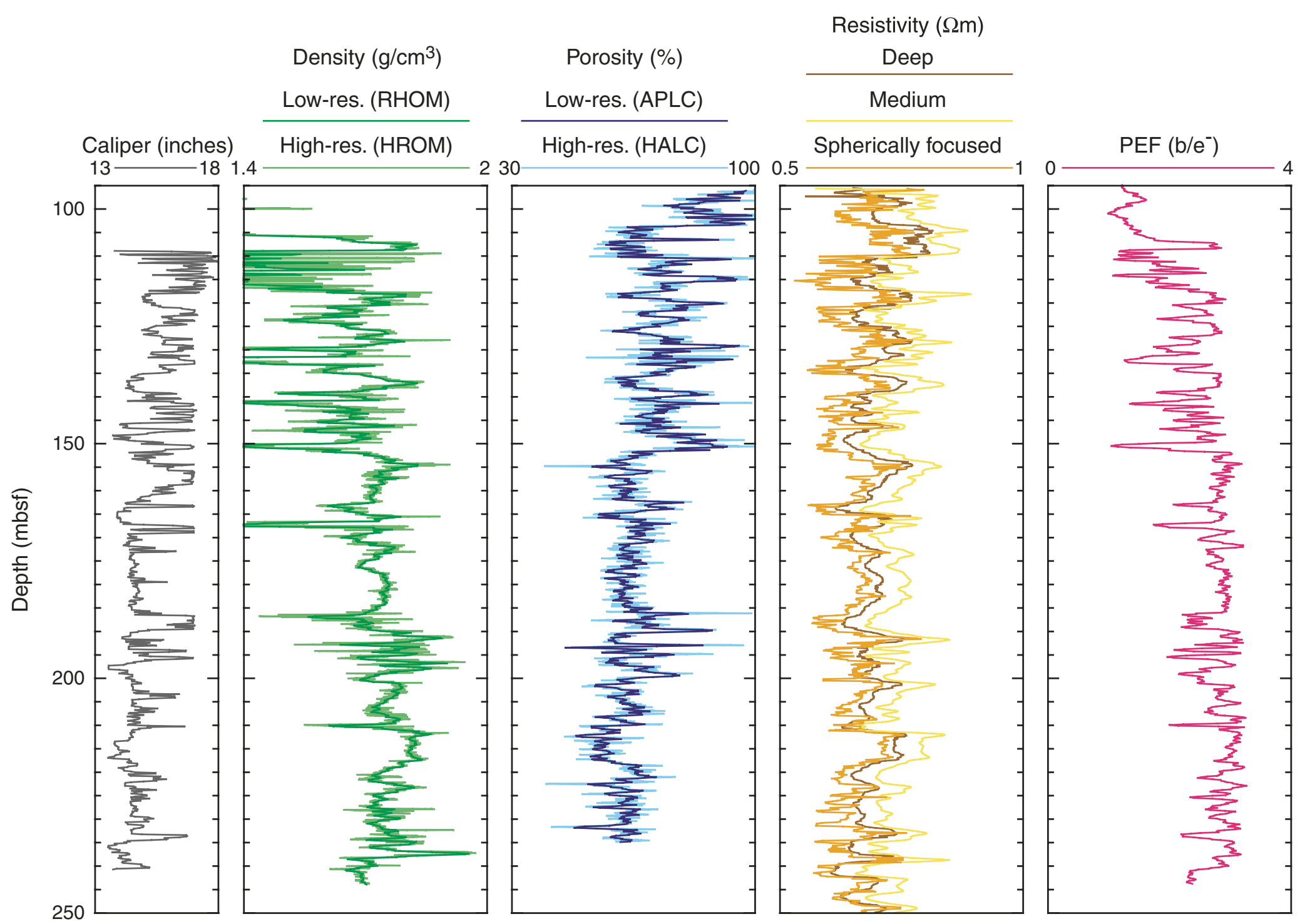


Figure F37. Caliper, total gamma ray and spectral gamma ray data (K, Th, and U) for the 95-250 mbsf interval, Hole U1305C. HCGR = computed gamma ray, HSGR = total spectral gamma ray, gAPI = American Petroleum Institute gamma ray units.

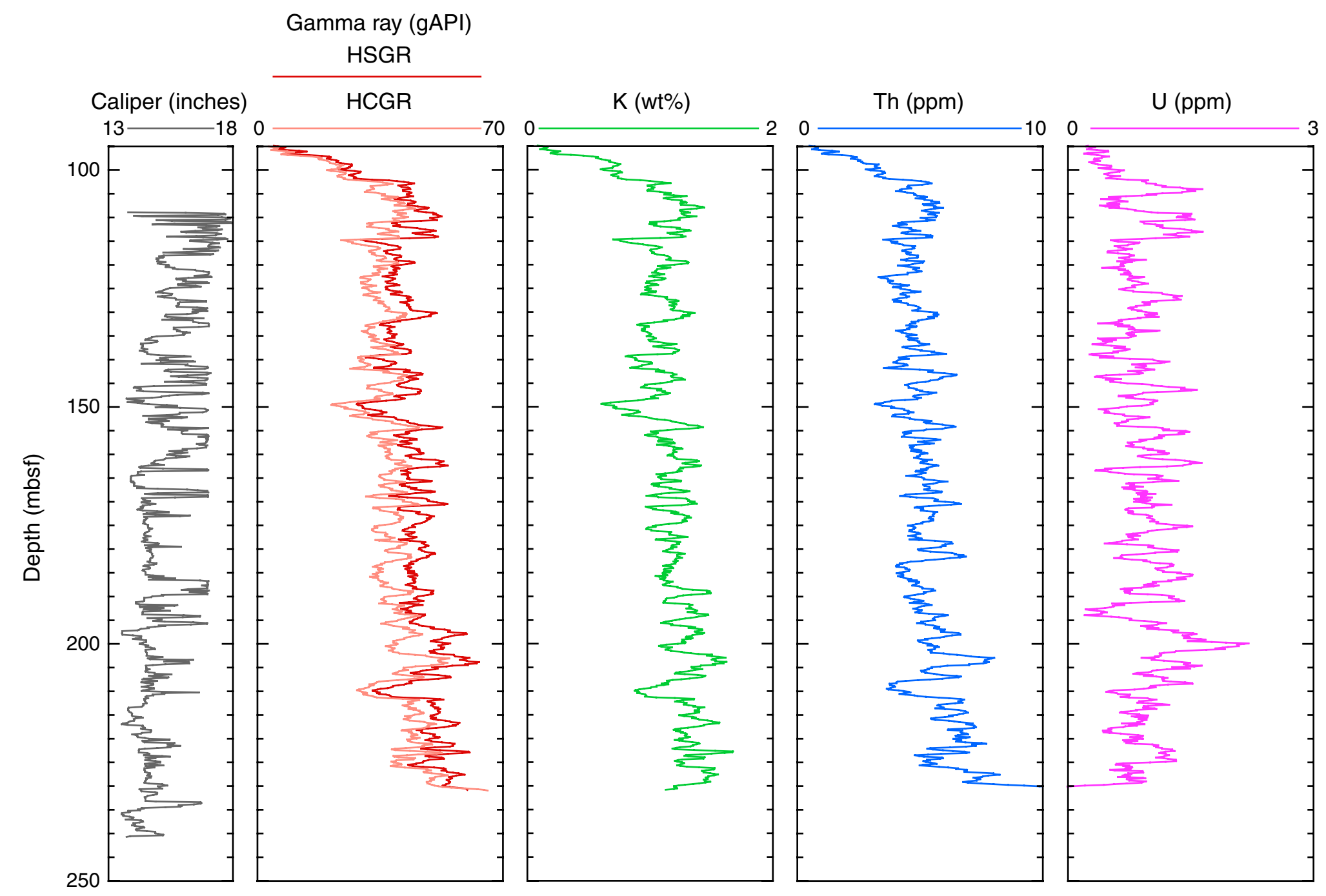


Figure F38. Comparison of core and logging physical properties from Hole U1305C. A. Gamma ray activity for the interval 95 to 250 mbsf. B. Density for the interval 95 to $250 \mathrm{mbsf}$. C. Gamma ray activity for the interval 190 to 215 mbsf. cps = counts per second; gAPI = American Petroleum Institute gamma ray units.

A

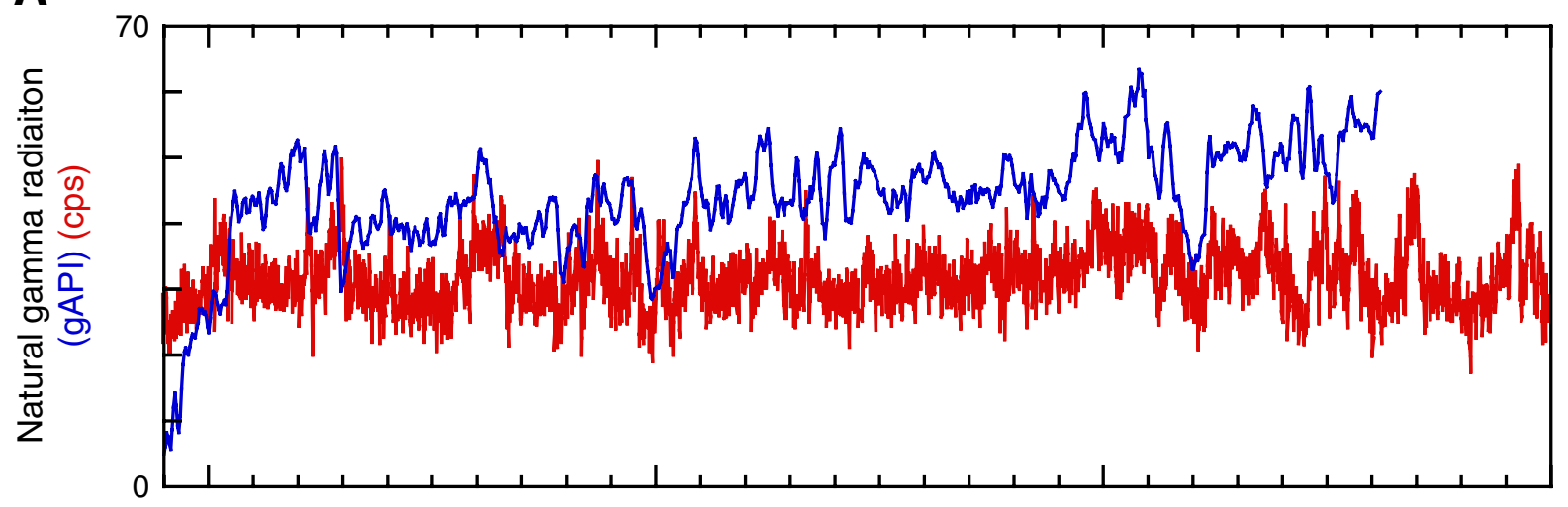

B

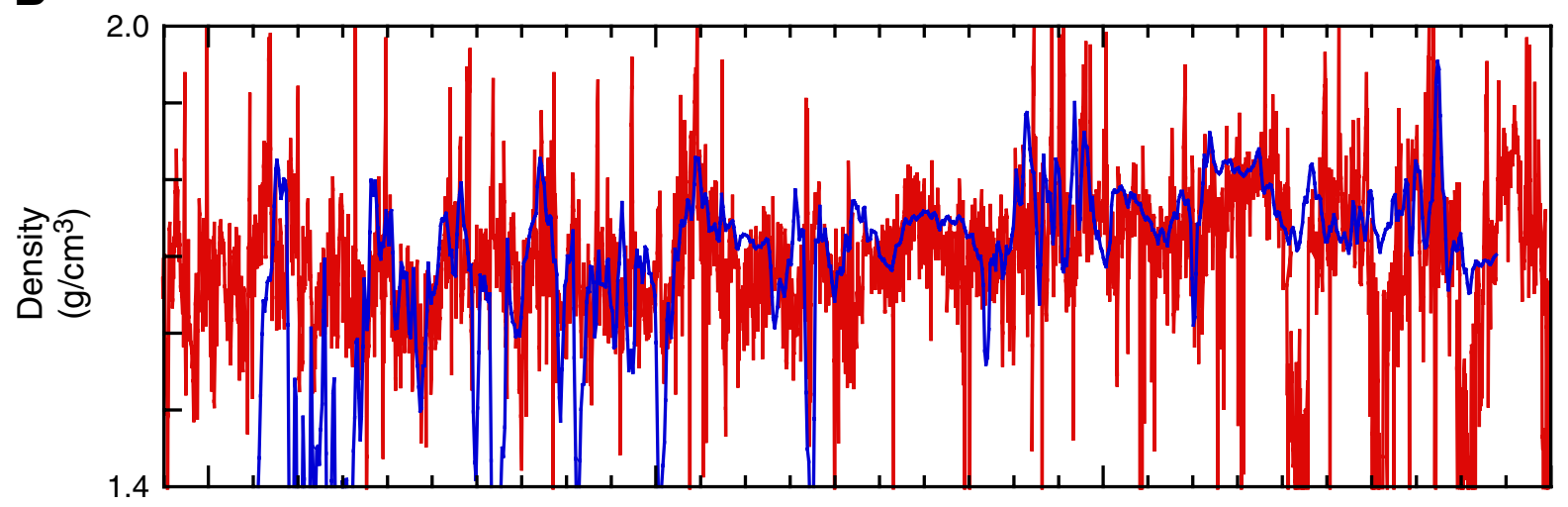

C

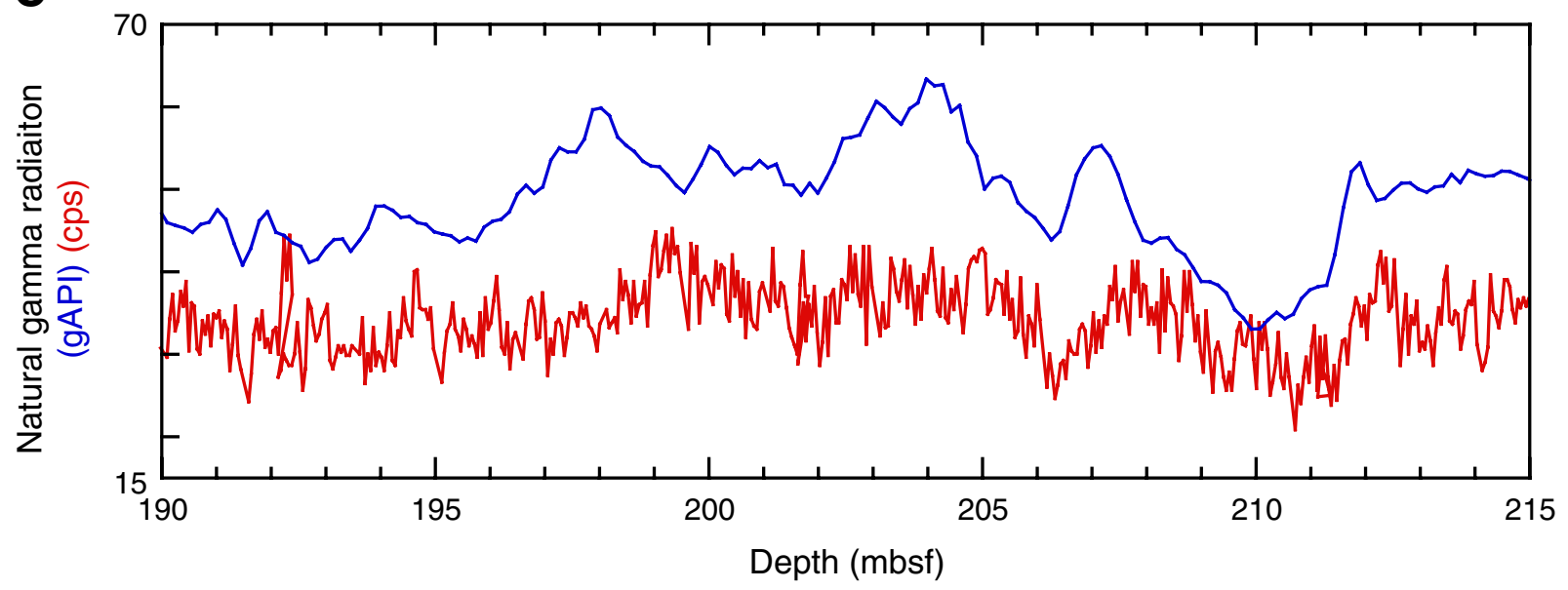

Core (Hole 1305C) data

Logging data 
Table T1. Coring summary, Site U1305. (See table note. Continued on next two pages.)

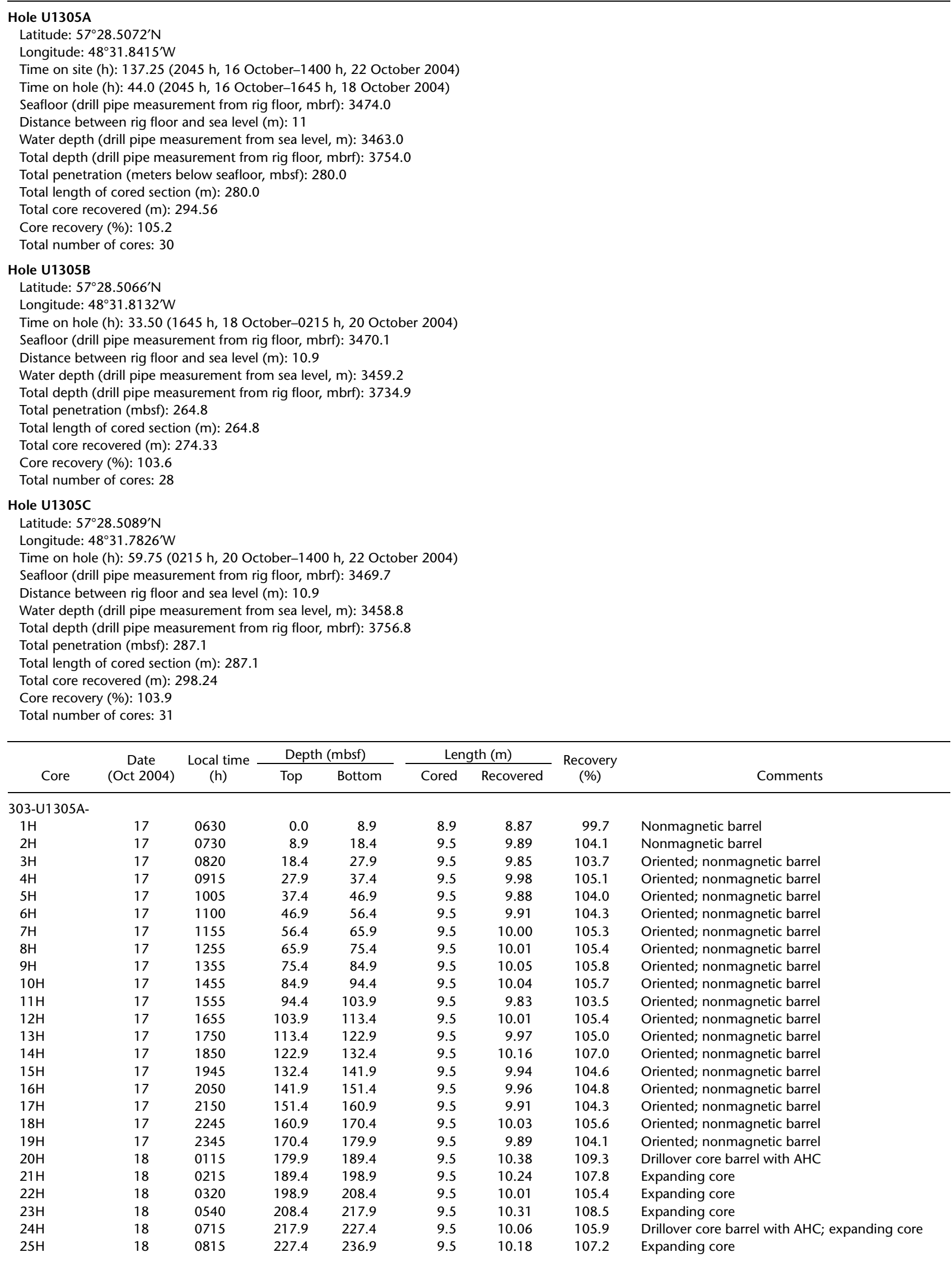


Table T1 (continued).

\begin{tabular}{|c|c|c|c|c|c|c|c|c|}
\hline \multirow[b]{2}{*}{ Core } & \multirow{2}{*}{$\begin{array}{c}\text { Date } \\
\text { (Oct 2004) }\end{array}$} & \multirow{2}{*}{$\begin{array}{l}\text { Local time } \\
\text { (h) }\end{array}$} & \multicolumn{2}{|c|}{ Depth (mbsf) } & \multicolumn{2}{|c|}{ Length $(\mathrm{m})$} & \multirow{2}{*}{$\begin{array}{c}\text { Recovery } \\
\text { (\%) }\end{array}$} & \multirow[b]{2}{*}{ Comments } \\
\hline & & & Top & Bottom & Cored & Recovered & & \\
\hline \multicolumn{9}{|c|}{ 303-U1305A- } \\
\hline $26 \mathrm{H}$ & 18 & 0930 & 236.9 & 246.4 & 9.5 & 10.14 & 106.7 & Drillover core barrel with $\mathrm{AHC}$; expanding core \\
\hline $27 \mathrm{H}$ & 18 & 1055 & 246.4 & 255.9 & 9.5 & 10.07 & 106.0 & Drillover core barrel with $\mathrm{AHC}$; expanding core \\
\hline $28 \mathrm{H}$ & 18 & 1245 & 255.9 & 265.4 & 9.5 & 9.99 & 105.2 & Drillover core barrel; expanding core \\
\hline $29 \mathrm{H}$ & 18 & 1410 & 265.4 & 273.4 & 8.0 & 8.40 & 105.0 & Drillover core barrel; expanding core \\
\hline \multirow[t]{2}{*}{$30 \mathrm{H}$} & 18 & 1515 & 273.4 & 280.0 & 6.6 & 6.60 & 100.0 & Expanding core \\
\hline & & & & Totals: & 280.0 & 294.56 & 105.2 & \\
\hline \multicolumn{9}{|c|}{ 303-U1305B- } \\
\hline $1 \mathrm{H}$ & 18 & 2015 & 0.0 & 8.3 & 8.3 & 8.25 & 99.4 & Nonmagnetic barrel \\
\hline $2 \mathrm{H}$ & 18 & 2055 & 8.3 & 17.8 & 9.5 & 9.85 & 103.7 & Nonmagnetic barrel \\
\hline $3 \mathrm{H}$ & 18 & 2155 & 17.8 & 27.3 & 9.5 & 9.84 & 103.6 & Oriented; nonmagnetic barrel \\
\hline $4 \mathrm{H}$ & 18 & 2250 & 27.3 & 36.8 & 9.5 & 9.85 & 103.7 & Oriented; nonmagnetic barrel \\
\hline $5 \mathrm{H}$ & 18 & 2350 & 36.8 & 46.3 & 9.5 & 9.94 & 104.6 & Oriented; nonmagnetic barrel \\
\hline $6 \mathrm{H}$ & 19 & 0045 & 46.3 & 55.8 & 9.5 & 6.82 & 71.8 & Oriented; nonmagnetic barrel \\
\hline 7H & 19 & 0145 & 55.8 & 65.3 & 9.5 & 9.91 & 104.3 & Oriented; nonmagnetic barrel \\
\hline $8 \mathrm{H}$ & 19 & 0240 & 65.3 & 74.8 & 9.5 & 10.11 & 106.4 & Oriented; nonmagnetic barrel \\
\hline $9 \mathrm{H}$ & 19 & 0335 & 74.8 & 84.3 & 9.5 & 10.11 & 106.4 & Oriented; nonmagnetic barrel \\
\hline $10 \mathrm{H}$ & 19 & 0430 & 84.3 & 93.8 & 9.5 & 9.98 & 105.1 & Oriented; nonmagnetic barrel \\
\hline $11 \mathrm{H}$ & 19 & 0530 & 93.8 & 103.3 & 9.5 & 10.10 & 106.3 & Oriented; nonmagnetic barrel \\
\hline $12 \mathrm{H}$ & 19 & 0630 & 103.3 & 112.8 & 9.5 & 9.68 & 101.9 & Oriented; nonmagnetic barrel \\
\hline $13 \mathrm{H}$ & 19 & 0740 & 112.8 & 122.3 & 9.5 & 10.17 & 107.1 & Oriented; nonmagnetic barrel \\
\hline $14 \mathrm{H}$ & 19 & 0845 & 122.3 & 131.8 & 9.5 & 10.02 & 105.5 & Oriented; nonmagnetic barrel \\
\hline $15 \mathrm{H}$ & 19 & 0940 & 131.8 & 141.3 & 9.5 & 9.77 & 102.8 & Oriented; nonmagnetic barrel \\
\hline $16 \mathrm{H}$ & 19 & 1040 & 141.3 & 150.8 & 9.5 & 10.06 & 105.9 & Oriented; nonmagnetic barrel \\
\hline $17 \mathrm{H}$ & 19 & 1155 & 150.8 & 160.3 & 9.5 & 10.19 & 107.3 & Oriented; nonmagnetic barrel; expanding core \\
\hline $18 \mathrm{H}$ & 19 & 1250 & 160.3 & 169.8 & 9.5 & 10.09 & 106.2 & Oriented; nonmagnetic barrel; expanding core \\
\hline $19 \mathrm{H}$ & 19 & 1350 & 169.8 & 179.3 & 9.5 & 10.26 & 108.0 & Oriented; nonmagnetic barrel; expanding core \\
\hline $20 \mathrm{H}$ & 19 & 1455 & 179.3 & 188.8 & 9.5 & 10.12 & 106.5 & Oriented; nonmagnetic barrel; expanding core \\
\hline $21 \mathrm{H}$ & 19 & 1610 & 188.8 & 198.3 & 9.5 & 10.14 & 106.7 & Oriented; nonmagnetic barrel; expanding core \\
\hline $22 \mathrm{H}$ & 19 & 1720 & 198.3 & 207.8 & 9.5 & 9.95 & 104.7 & Oriented; nonmagnetic barrel; expanding core \\
\hline $23 \mathrm{H}$ & 19 & 1825 & 207.8 & 217.3 & 9.5 & 10.16 & 107.0 & Oriented; nonmagnetic barrel; expanding core \\
\hline $24 \mathrm{H}$ & 19 & 1930 & 217.3 & 226.8 & 9.5 & 10.21 & 107.5 & Oriented; nonmagnetic barrel; expanding core \\
\hline $25 \mathrm{H}$ & 19 & 2100 & 226.8 & 236.3 & 9.5 & 10.04 & 105.7 & Drillover core barrel; expanding core \\
\hline $26 \mathrm{H}$ & 19 & 2155 & 236.3 & 245.8 & 9.5 & 9.65 & 101.6 & Expanding core \\
\hline $27 \mathrm{H}$ & 19 & 2255 & 245.8 & 255.3 & 9.5 & 8.97 & 94.4 & Expanding core \\
\hline \multirow[t]{2}{*}{$28 \mathrm{H}$} & 20 & 0050 & 255.3 & 264.8 & 9.5 & 10.09 & 106.2 & Drillover core barrel with $\mathrm{AHC}$; expanding core \\
\hline & & & & Totals: & 264.8 & 274.33 & 103.6 & \\
\hline 303-U1305 & & & & & & & & \\
\hline $1 \mathrm{H}$ & 20 & 0420 & 0.0 & 5.7 & 5.7 & 5.67 & 99.5 & Nonmagnetic barrel \\
\hline $2 \mathrm{H}$ & 20 & 0515 & 5.7 & 15.2 & 9.5 & 8.49 & 89.4 & Nonmagnetic barrel \\
\hline $3 \mathrm{H}$ & 20 & 0615 & 15.2 & 24.7 & 9.5 & 9.51 & 100.1 & Oriented; nonmagnetic barrel \\
\hline $4 \mathrm{H}$ & 20 & 0720 & 24.7 & 34.2 & 9.5 & 9.76 & 102.7 & Oriented; nonmagnetic barrel \\
\hline $5 \mathrm{H}$ & 20 & 0815 & 34.2 & 43.7 & 9.5 & 9.64 & 101.5 & Oriented; nonmagnetic barrel \\
\hline $6 \mathrm{H}$ & 20 & 0910 & 43.7 & 53.2 & 9.5 & 9.83 & 103.5 & Oriented; nonmagnetic barrel \\
\hline $7 \mathrm{H}$ & 20 & 1005 & 53.2 & 62.7 & 9.5 & 9.67 & 101.8 & Oriented; nonmagnetic barrel \\
\hline $8 \mathrm{H}$ & 20 & 1100 & 62.7 & 72.2 & 9.5 & 9.80 & 103.2 & Oriented; nonmagnetic barrel \\
\hline $9 \mathrm{H}$ & 20 & 1210 & 72.2 & 81.7 & 9.5 & 9.77 & 102.8 & Oriented; nonmagnetic barrel \\
\hline $10 \mathrm{H}$ & 20 & 1300 & 81.7 & 91.2 & 9.5 & 9.87 & 103.9 & Oriented; nonmagnetic barrel \\
\hline $11 \mathrm{H}$ & 20 & 1355 & 91.2 & 100.7 & 9.5 & 9.98 & 105.1 & Oriented; nonmagnetic barrel \\
\hline $12 \mathrm{H}$ & 20 & 1450 & 100.7 & 110.2 & 9.5 & 10.01 & 105.4 & Oriented; nonmagnetic barrel \\
\hline $13 \mathrm{H}$ & 20 & 1545 & 110.2 & 119.7 & 9.5 & 10.00 & 105.3 & Oriented; nonmagnetic barrel \\
\hline $14 \mathrm{H}$ & 20 & 1635 & 119.7 & 129.2 & 9.5 & 9.99 & 105.2 & Oriented; nonmagnetic barrel \\
\hline $15 \mathrm{H}$ & 20 & 1740 & 129.2 & 138.7 & 9.5 & 10.15 & 106.8 & Oriented; nonmagnetic barrel \\
\hline $16 \mathrm{H}$ & 20 & 1835 & 138.7 & 148.2 & 9.5 & 9.97 & 105.0 & Oriented; nonmagnetic barrel \\
\hline $17 \mathrm{H}$ & 20 & 1930 & 148.2 & 157.7 & 9.5 & 10.19 & 107.3 & Oriented; nonmagnetic barrel \\
\hline $18 \mathrm{H}$ & 20 & 2030 & 157.7 & 167.2 & 9.5 & 10.08 & 106.1 & Oriented; nonmagnetic barrel \\
\hline $19 \mathrm{H}$ & 20 & 2130 & 167.2 & 173.1 & 5.9 & 5.91 & 100.2 & Oriented; nonmagnetic barrel \\
\hline $20 \mathrm{H}$ & 20 & 2230 & 173.1 & 182.6 & 9.5 & 9.86 & 103.8 & Oriented; nonmagnetic barrel \\
\hline $21 \mathrm{H}$ & 21 & 0020 & 182.6 & 192.1 & 9.5 & 10.14 & 106.7 & Oriented; nonmagnetic barrel \\
\hline $22 \mathrm{H}$ & 21 & 0135 & 192.1 & 201.6 & 9.5 & 10.05 & 105.8 & Oriented; nonmagnetic barrel \\
\hline $23 \mathrm{H}$ & 21 & 0240 & 201.6 & 211.1 & 9.5 & 10.05 & 105.8 & Oriented; nonmagnetic barrel \\
\hline $24 \mathrm{H}$ & 21 & 0340 & 211.1 & 220.6 & 9.5 & 10.33 & 108.7 & Oriented; nonmagnetic barrel \\
\hline $25 \mathrm{H}$ & 21 & 0440 & 220.6 & 230.1 & 9.5 & 9.92 & 104.4 & \\
\hline $26 \mathrm{H}$ & 21 & 0555 & 230.1 & 239.6 & 9.5 & 10.28 & 108.2 & \\
\hline $27 \mathrm{H}$ & 21 & 0700 & 239.6 & 249.1 & 9.5 & 10.25 & 107.9 & \\
\hline $28 \mathrm{H}$ & 21 & 0810 & 249.1 & 258.6 & 9.5 & 10.22 & 107.6 & \\
\hline
\end{tabular}


Table T1 (continued).

\begin{tabular}{|c|c|c|c|c|c|c|c|c|}
\hline \multirow[b]{2}{*}{ Core } & \multirow{2}{*}{$\begin{array}{c}\text { Date } \\
\text { (Oct 2004) }\end{array}$} & \multirow{2}{*}{$\begin{array}{l}\text { Local time } \\
\text { (h) }\end{array}$} & \multicolumn{2}{|c|}{ Depth (mbsf) } & \multicolumn{2}{|c|}{ Length $(\mathrm{m})$} & \multirow{2}{*}{$\begin{array}{c}\text { Recovery } \\
\text { (\%) }\end{array}$} & \multirow[b]{2}{*}{ Comments } \\
\hline & & & Top & Bottom & Cored & Recovered & & \\
\hline \multicolumn{9}{|c|}{ 303-U1305C- } \\
\hline $29 \mathrm{H}$ & 21 & 0910 & 258.6 & 268.1 & 9.5 & 9.71 & 102.2 & \\
\hline $30 \mathrm{H}$ & 21 & 1015 & 268.1 & 277.6 & 9.5 & 8.86 & 93.3 & \\
\hline \multirow[t]{2}{*}{$31 \mathrm{H}$} & 21 & 1140 & 277.6 & 287.1 & 9.5 & 10.28 & 108.2 & \\
\hline & & & & Totals: & 287.1 & 298.24 & 103.9 & \\
\hline
\end{tabular}

Note: $\mathrm{AHC}=$ Active heave compensator. 
Table T2. Occurrences and thickness of detrital carbonate, Holes U1305A, U1305B, and U1305C.

\begin{tabular}{|c|c|c|c|c|}
\hline \multicolumn{2}{|c|}{ Core, section, interval $(\mathrm{cm})$} & \multicolumn{2}{|c|}{ Depth (mcd) } & \multirow{2}{*}{$\begin{array}{l}\text { Thickness } \\
(\mathrm{cm})\end{array}$} \\
\hline Top & Base & Top & Base & \\
\hline 303-U1305A- & 303-U1305A- & & & \\
\hline $1 \mathrm{H}-5,44$ & $1 \mathrm{H}-5,47$ & 10.32 & 10.35 & 3 \\
\hline $1 \mathrm{H}-5,93$ & $1 \mathrm{H}-5,97$ & 10.81 & 10.85 & 4 \\
\hline $1 \mathrm{H}-6,8$ & $1 \mathrm{H}-6,12$ & 11.46 & 11.50 & 4 \\
\hline $1 \mathrm{H}-6,36$ & $1 \mathrm{H}-6,45$ & 11.74 & 11.83 & 9 \\
\hline $3 \mathrm{H}-4,144$ & $3 \mathrm{H}-5,4$ & 29.85 & 29.95 & 10 \\
\hline $4 \mathrm{H}-2,57$ & $4 \mathrm{H}-2,62$ & 36.55 & 36.62 & 7 \\
\hline $4 \mathrm{H}-6,7$ & $4 \mathrm{H}-6,21$ & 42.05 & 42.19 & 14 \\
\hline $5 \mathrm{H}-3,55$ & $5 \mathrm{H}-3,58$ & 48.26 & 48.29 & 3 \\
\hline $5 \mathrm{H}-3,118$ & $5 \mathrm{H}-3,120$ & 48.89 & 48.91 & 2 \\
\hline $5 \mathrm{H}-4,92$ & $5 \mathrm{H}-4,104$ & 50.13 & 50.25 & 12 \\
\hline $5 \mathrm{H}-5,122$ & $5 \mathrm{H}-6,2$ & 51.93 & 52.23 & 30 \\
\hline $7 \mathrm{H}-6,76$ & 7H-6, 81 & 74.85 & 74.90 & 5 \\
\hline $8 \mathrm{H}-1,0$ & $8 \mathrm{H}-1,12$ & 77.43 & 77.55 & 12 \\
\hline $8 \mathrm{H}-3,10$ & $8 \mathrm{H}-3,14$ & 80.53 & 80.57 & 4 \\
\hline $8 \mathrm{H}-4,111$ & $8 \mathrm{H}-4,132$ & 83.04 & 83.25 & 21 \\
\hline $11 \mathrm{H}-1,18$ & $11 \mathrm{H}-1,26$ & 109.07 & 109.15 & 8 \\
\hline $11 \mathrm{H}-1,94$ & $11 \mathrm{H}-1,98$ & 109.83 & 109.87 & 4 \\
\hline $11 \mathrm{H}-4,58$ & $11 \mathrm{H}-4,63$ & 113.97 & 114.02 & 5 \\
\hline $12 \mathrm{H}-1,129$ & $12 \mathrm{H}-1,136$ & 120.76 & 120.83 & 7 \\
\hline $12 \mathrm{H}-4,47$ & $12 \mathrm{H}-4,58$ & 124.44 & 124.55 & 11 \\
\hline $15 \mathrm{H}-2,72$ & $15 \mathrm{H}-2,75$ & 152.83 & 152.86 & 3 \\
\hline $15 \mathrm{H}-2,79$ & $15 \mathrm{H}-2,85$ & 152.90 & 152.96 & 6 \\
\hline $15 \mathrm{H}-4,53$ & $15 \mathrm{H}-4,56$ & 155.64 & 155.67 & 3 \\
\hline $15 \mathrm{H}-5,118$ & $15 \mathrm{H}-5,133$ & 157.79 & 157.94 & 15 \\
\hline $16 \mathrm{H}-1,13$ & $16 \mathrm{H}-1,26$ & 161.09 & 161.22 & 13 \\
\hline $16 \mathrm{H}-7,59$ & $16 \mathrm{H}-\mathrm{CC}, 24$ & 170.55 & 170.89 & 34 \\
\hline $18 \mathrm{H}-1,117$ & $18 \mathrm{H}-1,145$ & 182.70 & 182.98 & 28 \\
\hline $18 \mathrm{H}-6,148$ & $18 \mathrm{H}-\mathrm{CC}, 1$ & 190.53 & 191.30 & 77 \\
\hline $20 \mathrm{H}-6,30$ & $20 \mathrm{H}-6,58$ & 211.45 & 211.73 & 28 \\
\hline $21 \mathrm{H}-6,51$ & $21 \mathrm{H}-6,81$ & 221.79 & 222.09 & 30 \\
\hline $22 \mathrm{H}-7,14$ & $22 \mathrm{H}-7,39$ & 233.75 & 234.00 & 25 \\
\hline $24 \mathrm{H}-1,102$ & $24 \mathrm{H}-1,119$ & 246.40 & 246.57 & 17 \\
\hline $25 \mathrm{H}-2,55$ & $25 \mathrm{H}-2,92$ & 257.16 & 257.53 & 37 \\
\hline $25 \mathrm{H}-6,68$ & $25 \mathrm{H}-6,90$ & 263.26 & 263.48 & 22 \\
\hline $26 \mathrm{H}-3,32$ & $26 \mathrm{H}-3,51$ & 268.22 & 268.41 & 19 \\
\hline $28 \mathrm{H}-1,43$ & $28 \mathrm{H}-1,49$ & 286.03 & 286.09 & 6 \\
\hline
\end{tabular}

\begin{tabular}{|c|c|c|c|c|}
\hline \multicolumn{2}{|c|}{ Core, section, interval (cm) } & \multicolumn{2}{|c|}{ Depth (mcd) } & \multirow{2}{*}{$\begin{array}{l}\text { Thickness } \\
(\mathrm{cm})\end{array}$} \\
\hline Top & Base & Top & Base & \\
\hline 303-U1305B- & 303-U1305B- & & & \\
\hline $2 \mathrm{H}-1,137$ & $2 \mathrm{H}-1,140$ & 10.29 & 10.32 & 3 \\
\hline $2 \mathrm{H}-2,44$ & $2 \mathrm{H}-2,48$ & 10.86 & 10.90 & 4 \\
\hline $2 \mathrm{H}-2,67$ & $2 \mathrm{H}-2,70$ & 11.09 & 11.12 & 3 \\
\hline $2 \mathrm{H}-2,100$ & $2 \mathrm{H}-2,104$ & 11.42 & 11.46 & 4 \\
\hline $2 \mathrm{H}-2,138$ & $2 \mathrm{H}-2,147$ & 11.80 & 11.89 & 9 \\
\hline $4 \mathrm{H}-5,35$ & $4 \mathrm{H}-5,39$ & 36.54 & 36.58 & 4 \\
\hline $5 \mathrm{H}-1,138$ & $5 \mathrm{H}-1,146$ & 41.98 & 42.06 & 8 \\
\hline $5 \mathrm{H}-6,8$ & $5 \mathrm{H}-6,12$ & 48.18 & 48.22 & 4 \\
\hline $5 \mathrm{H}-6,65$ & $5 \mathrm{H}-6,66$ & 48.75 & 48.76 & 1 \\
\hline $5 \mathrm{H}-7,34$ & $5 \mathrm{H}-7,36$ & 49.94 & 49.96 & 2 \\
\hline $6 \mathrm{H}-1,44$ & $6 \mathrm{H}-1,48$ & 52.34 & 52.38 & 4 \\
\hline $8 \mathrm{H}-2,41$ & $8 \mathrm{H}-2,45$ & 74.84 & 74.88 & 4 \\
\hline $8 \mathrm{H}-4,68$ & $8 \mathrm{H}-4,71$ & 78.11 & 78.14 & 3 \\
\hline $8 \mathrm{H}-6,8$ & $8 \mathrm{H}-6,14$ & 80.51 & 80.57 & 6 \\
\hline $9 \mathrm{H}-1,2$ & $9 \mathrm{H}-1,10$ & 83.53 & 83.61 & 8 \\
\hline $11 \mathrm{H}-4,58$ & $11 \mathrm{H}-4,63$ & 109.22 & 109.27 & 5 \\
\hline $11 \mathrm{H}-4,128$ & $11 \mathrm{H}-4,132$ & 109.92 & 109.96 & 4 \\
\hline $11 \mathrm{H}-7,74$ & $11 \mathrm{H}-7,79$ & 113.88 & 113.93 & 5 \\
\hline $12 \mathrm{H}-5,65$ & $12 \mathrm{H}-5,69$ & 120.75 & 120.79 & 4 \\
\hline $15 \mathrm{H}-6,4$ & $15 \mathrm{H}-6,8$ & 152.81 & 152.85 & 4 \\
\hline $15 \mathrm{H}-6,12$ & $15 \mathrm{H}-6,18$ & 152.89 & 152.95 & 6 \\
\hline $16 \mathrm{H}-2,46$ & $16 \mathrm{H}-2,61$ & 157.76 & 157.91 & 15 \\
\hline $16 \mathrm{H}-4,65$ & $16 \mathrm{H}-4,84$ & 161.03 & 161.22 & 19 \\
\hline $17 \mathrm{H}-3,137$ & $17 \mathrm{H}-4,23$ & 170.52 & 170.88 & 36 \\
\hline $18 \mathrm{H}-5,10$ & $18 \mathrm{H}-5,40$ & 182.67 & 182.97 & 30 \\
\hline $19 \mathrm{H}-3,36$ & $19 \mathrm{H}-3,48$ & 190.48 & 190.60 & 12 \\
\hline $21 \mathrm{H}-2,61$ & $21 \mathrm{H}-2,82$ & 211.49 & 211.70 & 21 \\
\hline $23 \mathrm{H}-3,92$ & $23 \mathrm{H}-3,120$ & 233.75 & 234.03 & 28 \\
\hline $24 \mathrm{H}-5,24$ & $24 \mathrm{H}-5,54$ & 246.33 & 246.63 & 30 \\
\hline $25 \mathrm{H}-5,43$ & $25 \mathrm{H}-5,88$ & 257.09 & 257.54 & 45 \\
\hline $26 \mathrm{H}-2,80$ & $26 \mathrm{H}-2,102$ & 263.28 & 263.50 & 22 \\
\hline $26 \mathrm{H}-5,141$ & $26 \mathrm{H}-6,12$ & 268.41 & 268.61 & 20 \\
\hline $28 \mathrm{H}-4,9$ & $28 \mathrm{H}-4,22$ & 285.98 & 286.11 & 13 \\
\hline
\end{tabular}

\begin{tabular}{|c|c|c|c|c|}
\hline \multicolumn{2}{|c|}{ Core, section, interval $(\mathrm{cm})$} & \multicolumn{2}{|c|}{ Depth (mcd) } & \multirow{2}{*}{$\begin{array}{l}\text { Thickness } \\
(\mathrm{cm})\end{array}$} \\
\hline Top & Base & Top & Base & \\
\hline 303-U1305C- & 303-U1305C- & & & \\
\hline $2 \mathrm{H}-3,65$ & $2 \mathrm{H}-3,72$ & 10.28 & 10.35 & 7 \\
\hline $2 \mathrm{H}-3,113$ & $2 \mathrm{H}-3,118$ & 10.76 & 10.81 & 5 \\
\hline $2 \mathrm{H}-4,28$ & $2 \mathrm{H}-4,32$ & 11.41 & 11.45 & 4 \\
\hline $2 \mathrm{H}-4,54$ & $2 \mathrm{H}-4,62$ & 11.67 & 11.75 & 8 \\
\hline $4 \mathrm{H}-2,18$ & $4 \mathrm{H}-2,29$ & 29.77 & 29.88 & 11 \\
\hline $4 \mathrm{H}-6,98$ & $4 \mathrm{H}-6,104$ & 36.57 & 36.63 & 6 \\
\hline $5 \mathrm{H}-3,120$ & $5 \mathrm{H}-3,122$ & 42.04 & 42.06 & 2 \\
\hline $6 \mathrm{H}-1,43$ & $6 \mathrm{H}-1,46$ & 48.02 & 48.05 & 3 \\
\hline $6 \mathrm{H}-2,87$ & $6 \mathrm{H}-2,101$ & 49.96 & 50.10 & 14 \\
\hline $6 \mathrm{H}-3,147$ & $6 \mathrm{H}-4,13$ & 52.06 & 52.22 & 16 \\
\hline $6 \mathrm{H}-5,120$ & $6 \mathrm{H}-5,122$ & 54.79 & 54.81 & 2 \\
\hline $8 \mathrm{H}-4,130$ & $8 \mathrm{H}-4,133$ & 74.97 & 75.00 & 3 \\
\hline $8 \mathrm{H}-7,17$ & $8 \mathrm{H}-7,21$ & 78.34 & 78.38 & 4 \\
\hline $9 \mathrm{H}-3,91$ & $9 \mathrm{H}-3,110$ & 83.12 & 83.31 & 19 \\
\hline $12 \mathrm{H}-3,103$ & $12 \mathrm{H}-3,106$ & 113.93 & 113.96 & 3 \\
\hline $13 \mathrm{H}-3,80$ & $13 \mathrm{H}-3,88$ & 124.45 & 124.53 & 8 \\
\hline $16 \mathrm{H}-2,90$ & $16 \mathrm{H}-2,94$ & 155.65 & 155.69 & 4 \\
\hline $16 \mathrm{H}-4,32$ & $16 \mathrm{H}-4,47$ & 158.06 & 158.21 & 15 \\
\hline $16 \mathrm{H}-6,115$ & $16 \mathrm{H}-6,135$ & 161.88 & 162.08 & 20 \\
\hline $17 \mathrm{H}-5,24$ & $17 \mathrm{H}-5,62$ & 170.50 & 170.88 & 38 \\
\hline $18 \mathrm{H}-7,12$ & $18 \mathrm{H}-7,38$ & 182.69 & 182.95 & 26 \\
\hline $21 \mathrm{H}-7,72$ & $21 \mathrm{H}-\mathrm{CC}, 1$ & 211.64 & 211.87 & 23 \\
\hline $23 \mathrm{H}-1,12$ & $23 \mathrm{H}-1,20$ & 222.56 & 222.64 & 8 \\
\hline $24 \mathrm{H}-1,111$ & $24 \mathrm{H}-1,142$ & 233.68 & 233.99 & 31 \\
\hline $25 \mathrm{H}-4,32$ & $25 \mathrm{H}-4,62$ & 247.58 & 247.88 & 30 \\
\hline $26 \mathrm{H}-2,132$ & $26 \mathrm{H}-3,37$ & 257.05 & 257.54 & 49 \\
\hline $26 \mathrm{H}-7,109$ & $26 \mathrm{H}-\mathrm{CC}, 8$ & 264.22 & 264.33 & 11 \\
\hline $27 \mathrm{H}-4,35$ & $27 \mathrm{H}-4,41$ & 269.57 & 269.63 & 6 \\
\hline $29 \mathrm{H}-1,44$ & $29 \mathrm{H}-1,55$ & 286.50 & 286.61 & 11 \\
\hline
\end{tabular}




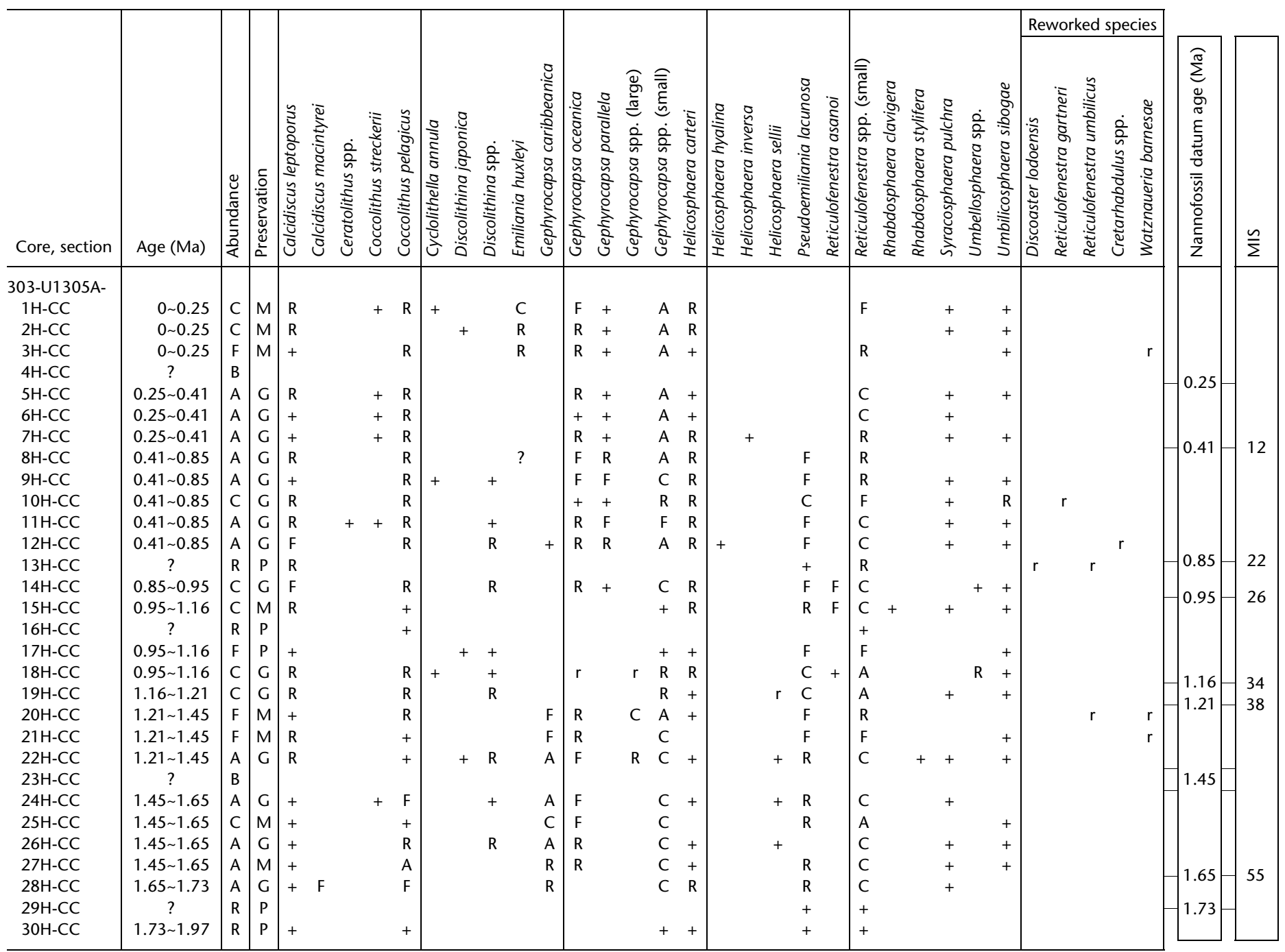

Notes: Abundance: $A=$ abundant, $C=$ common, $F=$ few, $R=$ rare, $+=$ present, $B=$ barren, $r=$ reworked. Preservation: $G=$ good, $M=$ moderate, $P=$ poor. $M I S=$ marine isotope stage (per Wei, 1993; Sato et al., 1999). 
Table T4. Distribution of calcareous nannofossils, Hole U1305B.



Notes: Abundance: $\mathrm{A}=$ abundant, $\mathrm{C}=$ common, $\mathrm{F}=$ few, $\mathrm{R}=$ rare, $+=$ present, $\mathrm{r}=$ reworked. Preservation: $\mathrm{G}=$ good, $\mathrm{M}=$ moderate, $\mathrm{P}=$ poor. $\mathrm{MIS}=$ marine isotope stage (per Wei, 1993; Sato et al., 1999). 


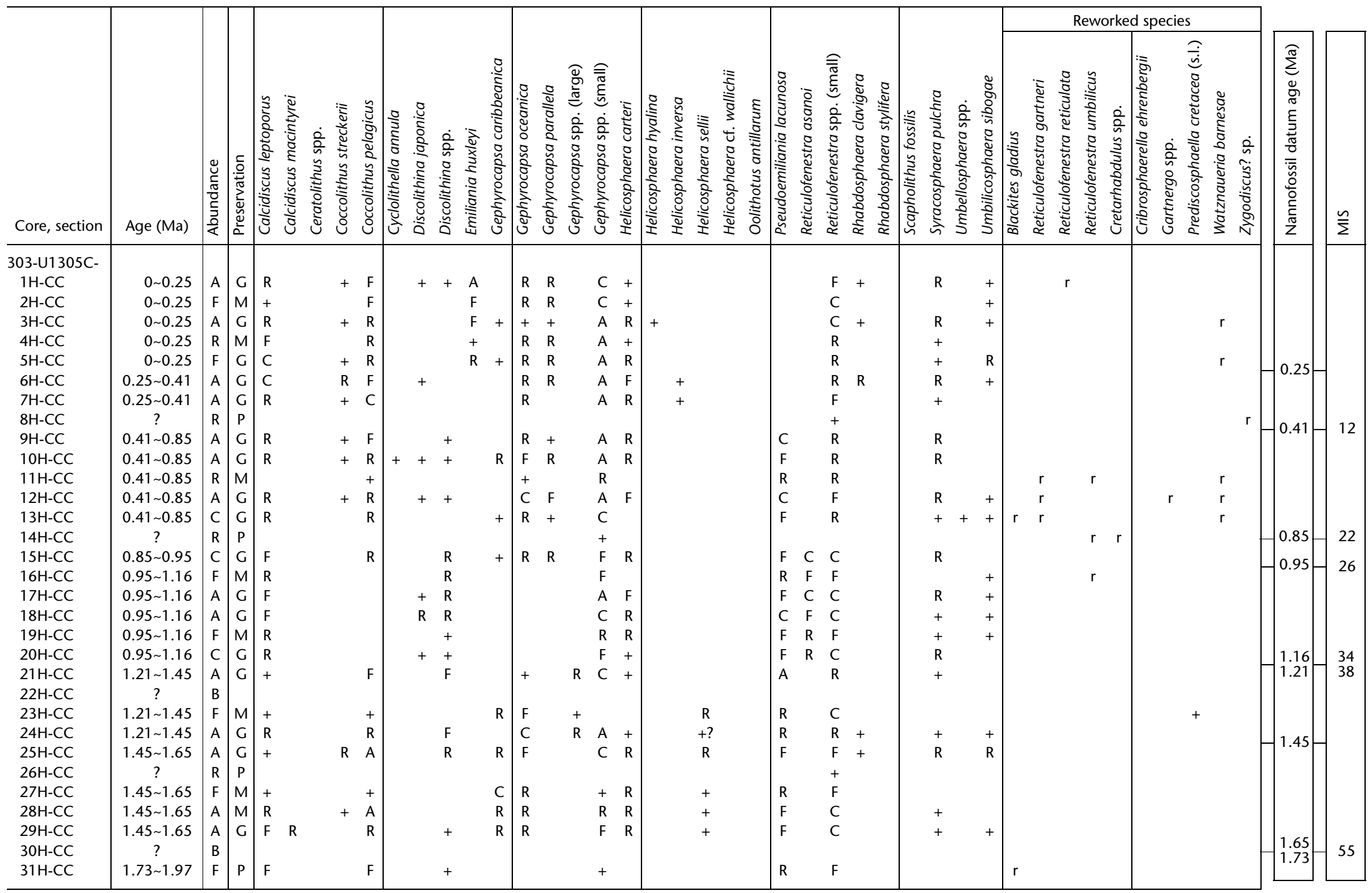

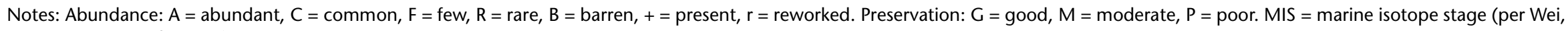
1993; Sato et al., 1999). 
Table T6. Distribution of planktonic foraminifers, Hole U1305A.

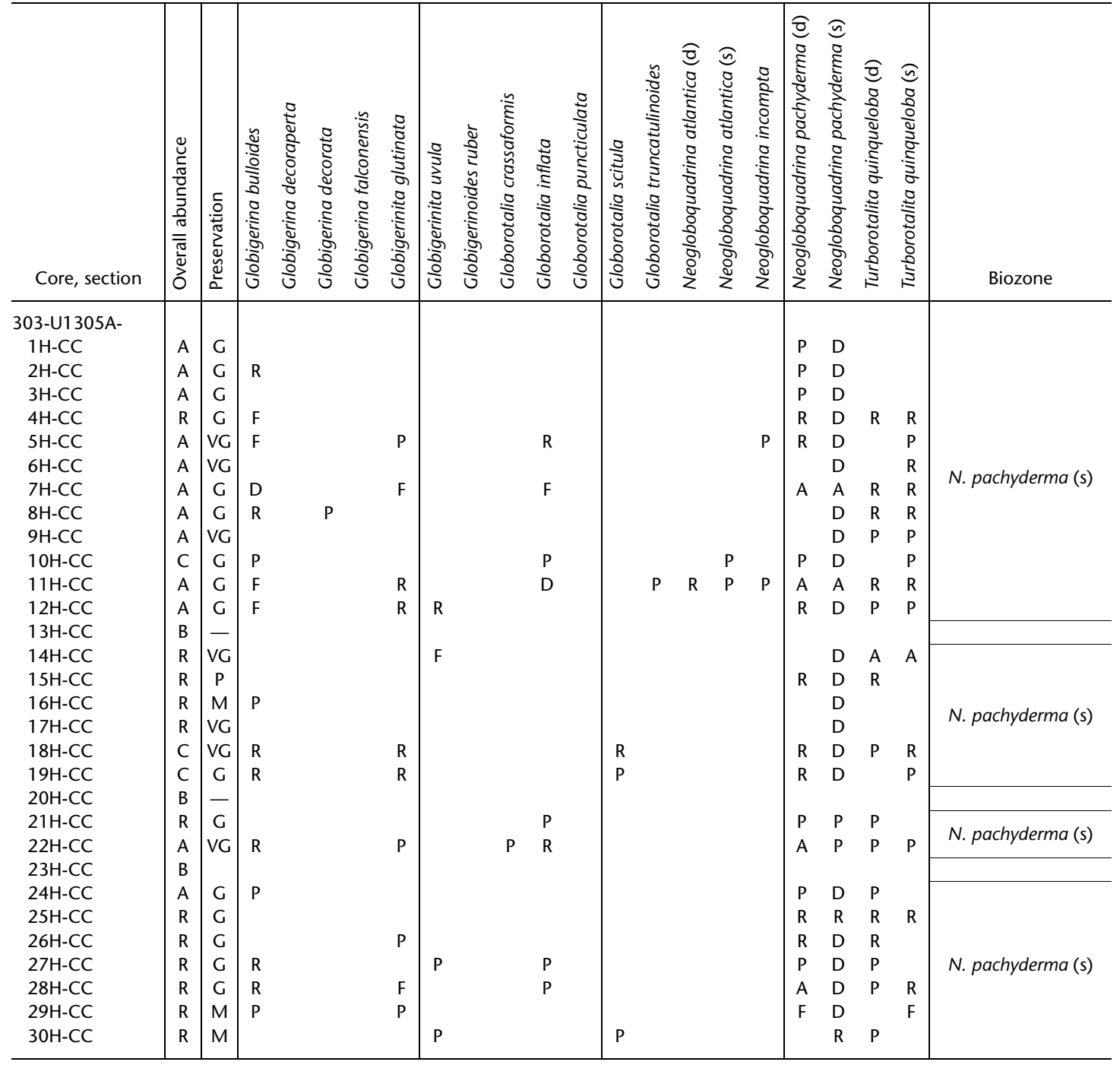

Notes: Abundance: $\mathrm{D}=$ dominant, $\mathrm{A}=$ abundant, $\mathrm{C}=$ common, $\mathrm{F}=$ few, $\mathrm{R}=$ rare, $\mathrm{P}=$ present, $\mathrm{B}=$ barren. Preservation: VG $=$ very good, $\mathrm{G}=$ good, $\mathrm{M}=$ moderate, $\mathrm{P}=$ poor (see "Foraminifers" in the "Site U1302-U1308 methods" chapter). $\mathrm{s}=$ sinistral. 
Table T7. Distribution of planktonic foraminifers, Hole U1305B.

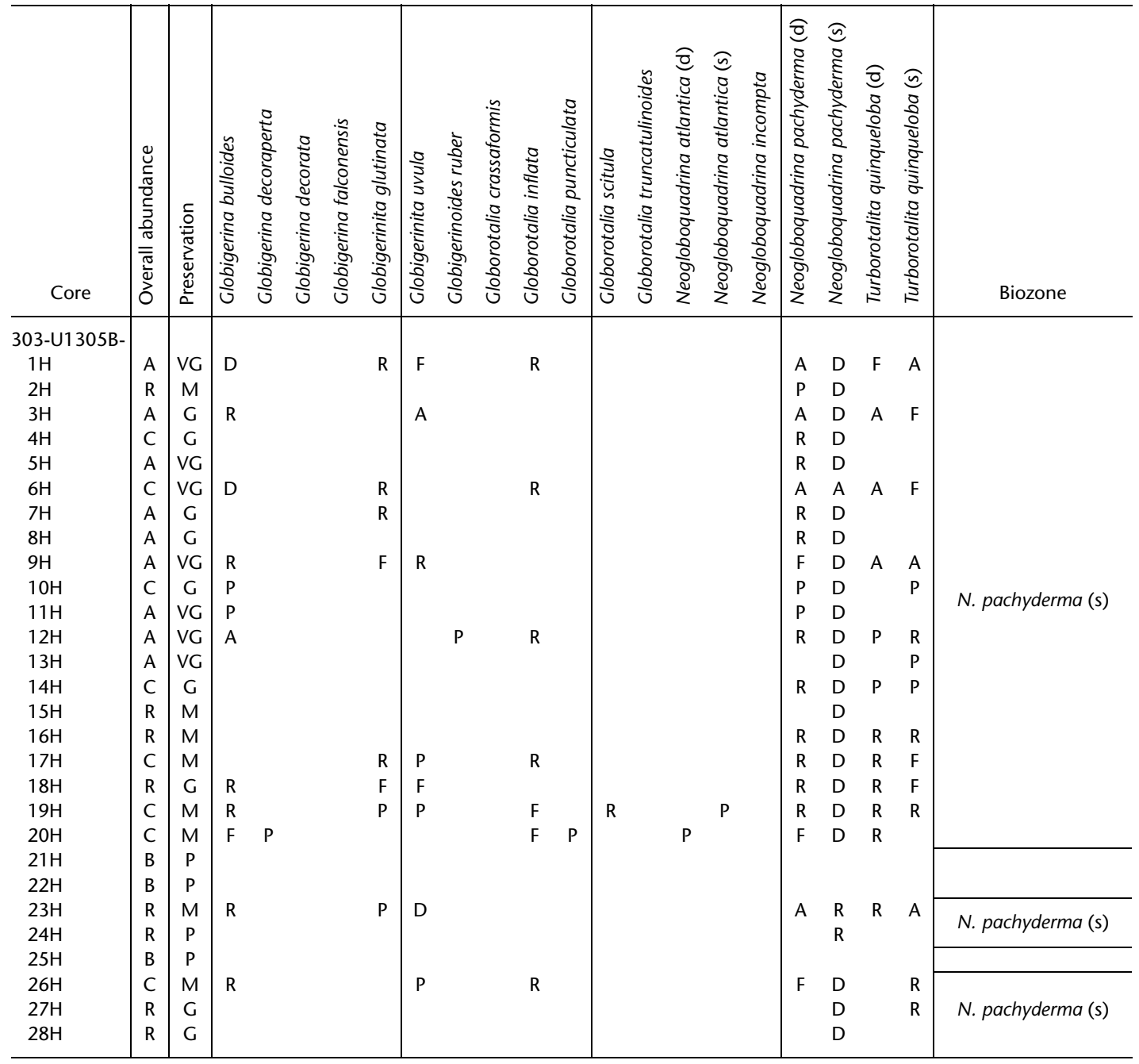

Notes: Abundance: $\mathrm{D}=$ dominant, $\mathrm{A}=$ abundant, $\mathrm{C}=$ common, $\mathrm{F}=$ few, $\mathrm{R}=$ rare, $\mathrm{P}=$ present, $\mathrm{B}=$ barren. Preservation: $\mathrm{VG}=$ very good, $\mathrm{G}=$ good, $M=$ moderate, $P=$ poor (see "Foraminifers" in the "Site U1302-U1308 methods" chapter). $d=$ dextral, $s=$ sinistral. 
Table T8. Distribution of planktonic foraminifers, Hole U1305C.

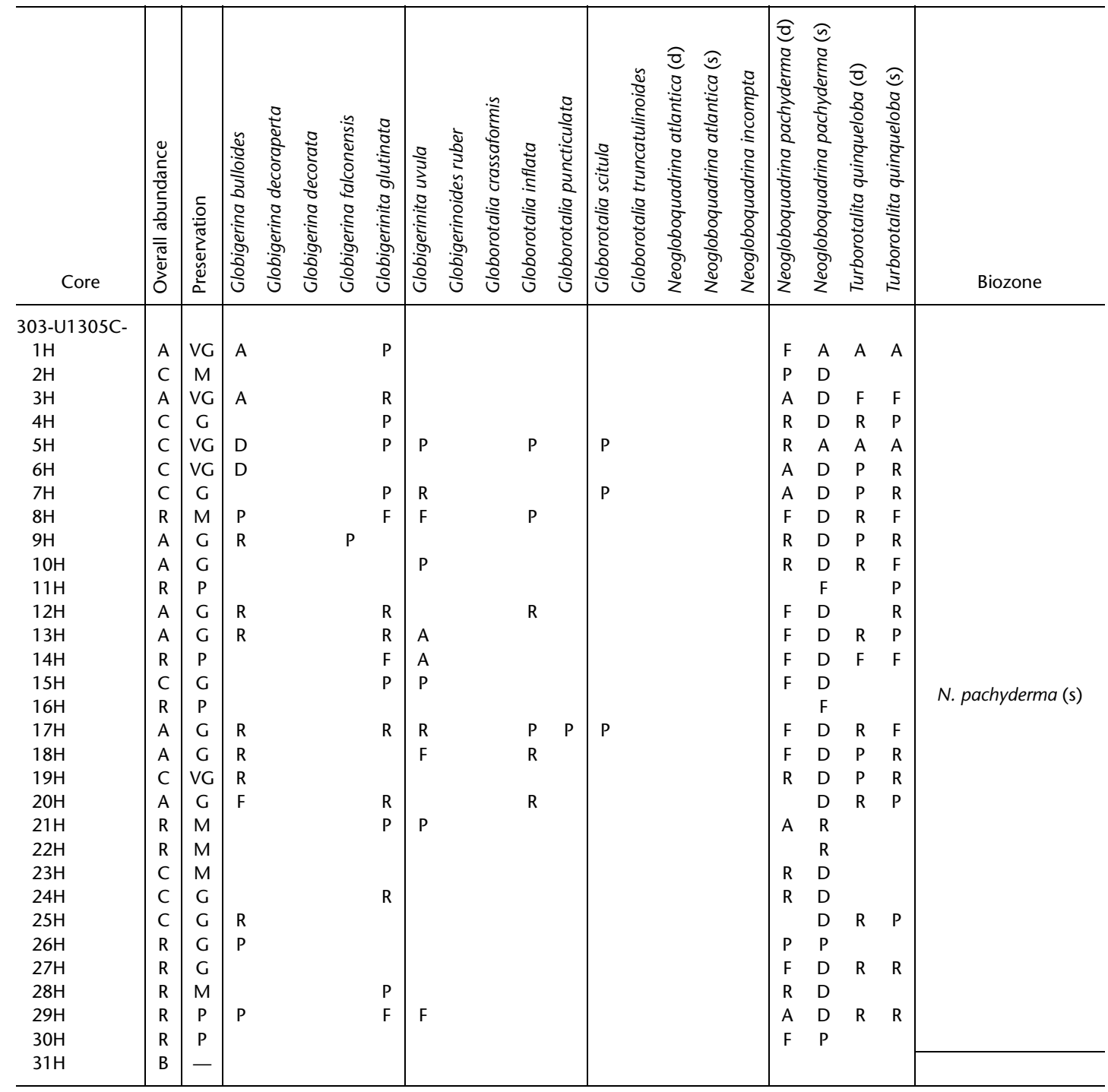

Notes: Abundance: $\mathrm{D}=$ dominant, $\mathrm{A}=$ abundant, $\mathrm{C}=$ common, $\mathrm{F}=$ few, $\mathrm{R}=$ rare, $\mathrm{P}=$ present, $\mathrm{B}=$ barren. Preservation: $\mathrm{VG}=$ very good, $\mathrm{G}=$ good, $M=$ moderate, $P=$ poor (see "Foraminifers" in the "Site U1302-U1308 methods" chapter). $d=$ dextral, $s=$ sinistral. 
Table T9. Distribution of benthic foraminifers, Hole U1305A.

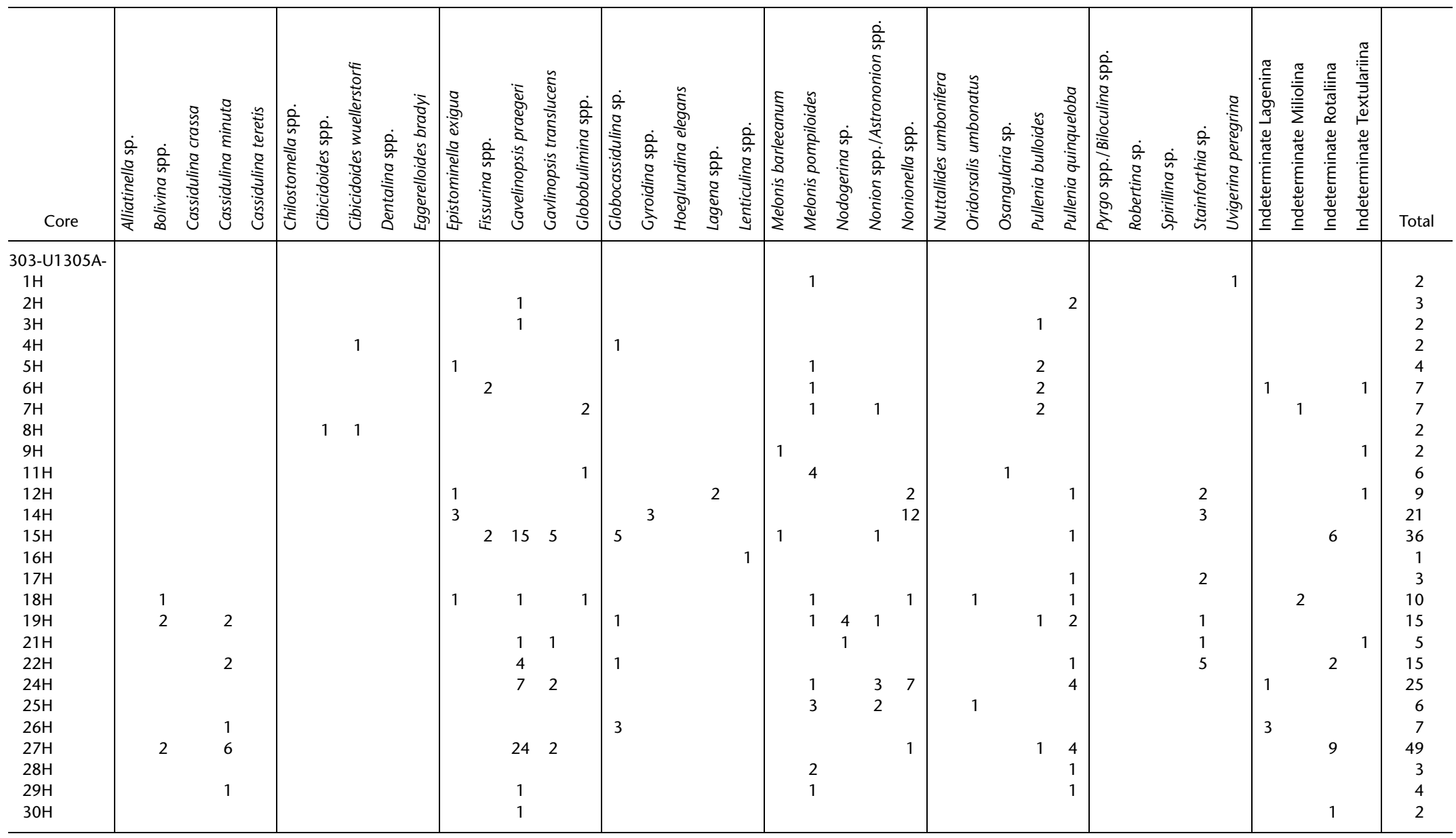

Notes: Numbers are total observations, which are not calibrated. Barren samples are not listed.

Table T10. Distribution of diatoms and silicoflagellates, Hole U1305A. (This table is available in an oversized format.) 

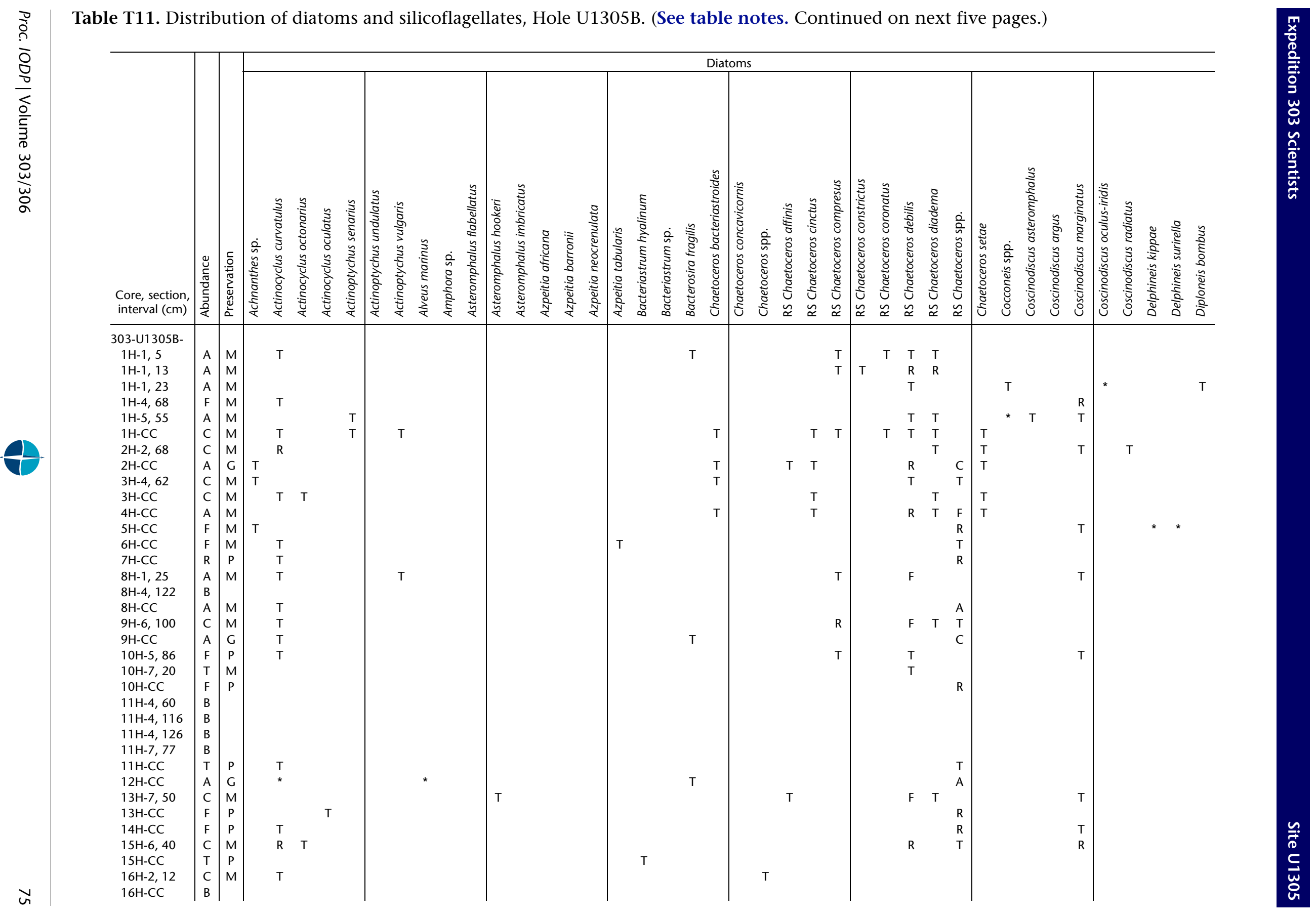

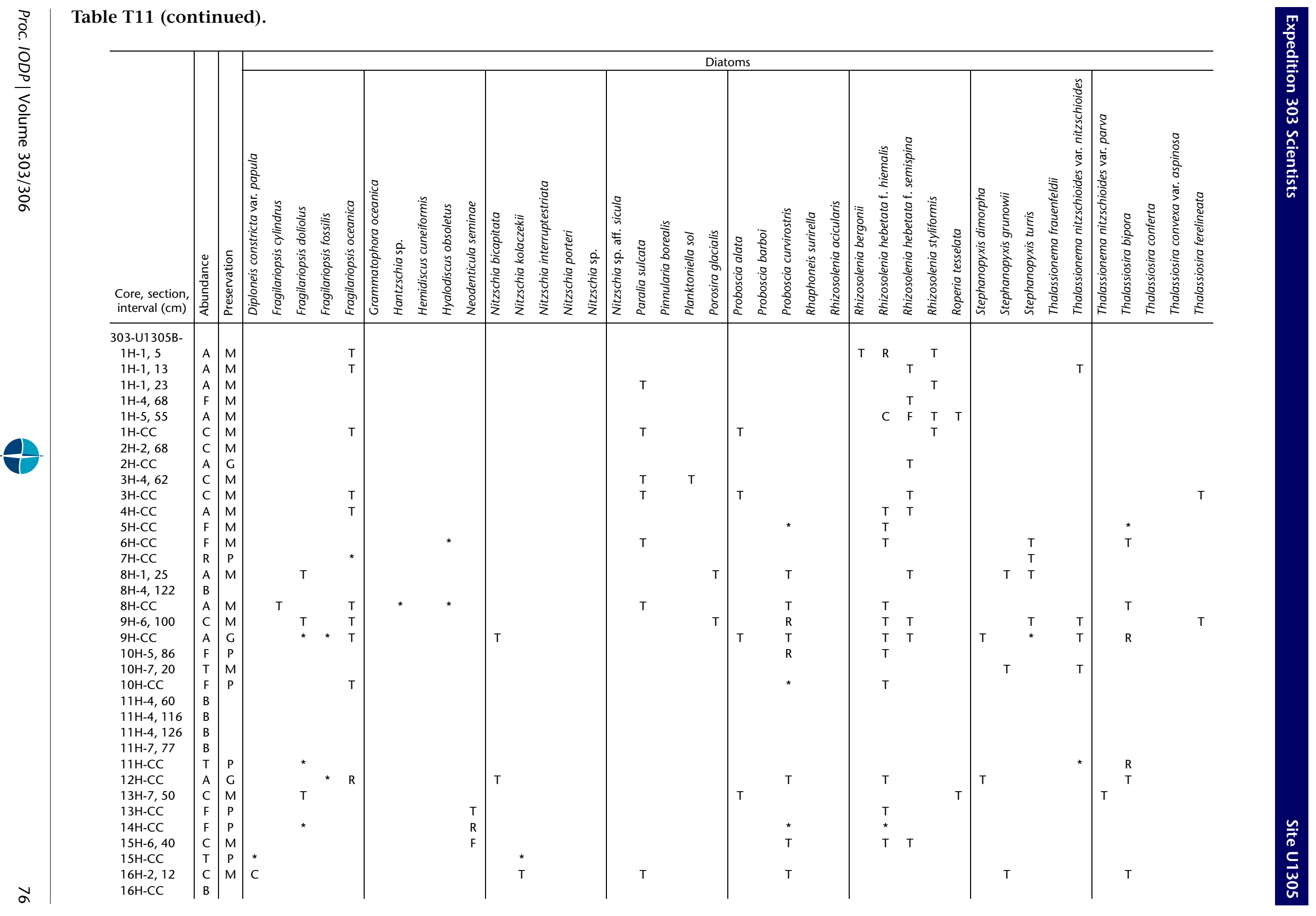

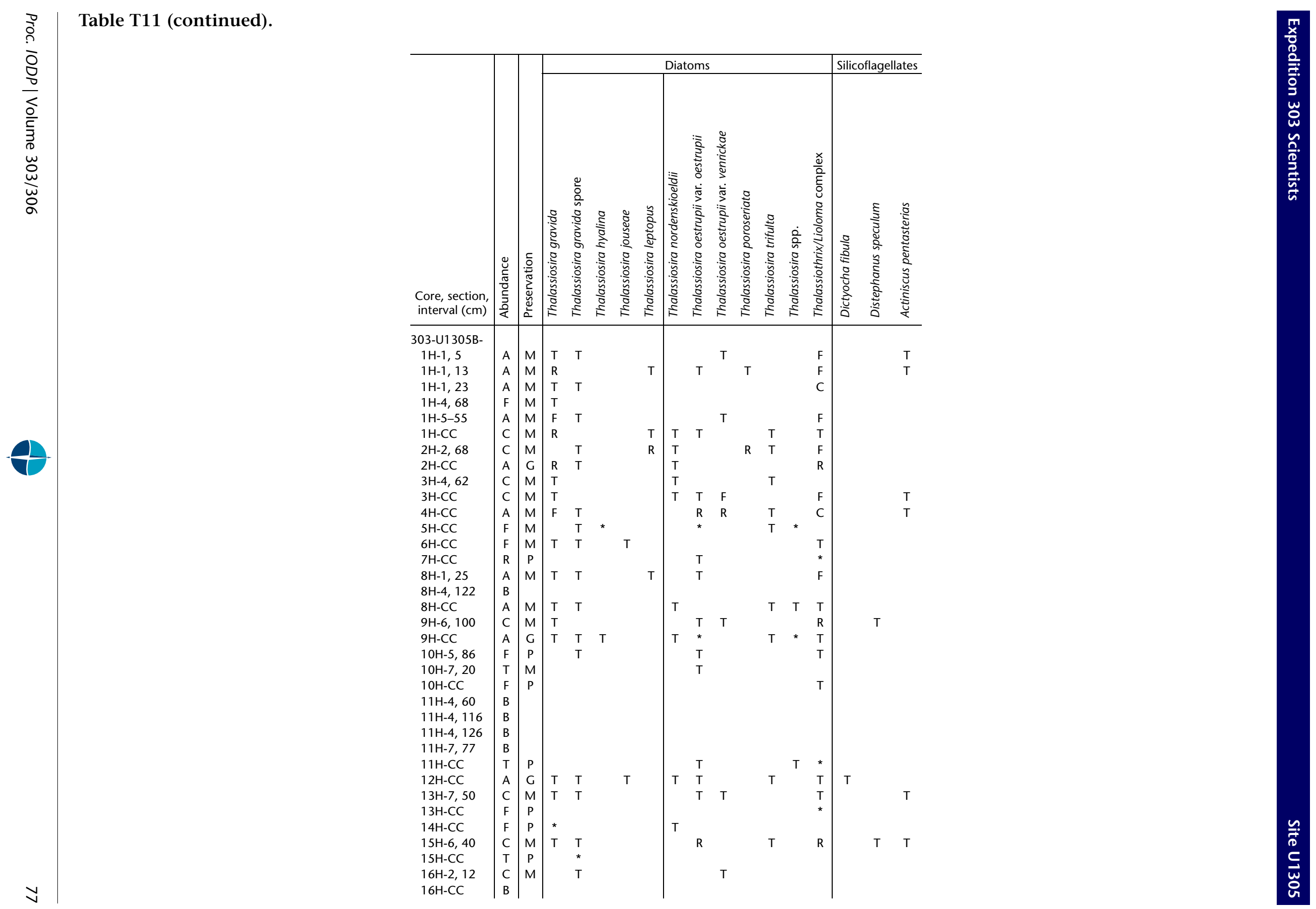


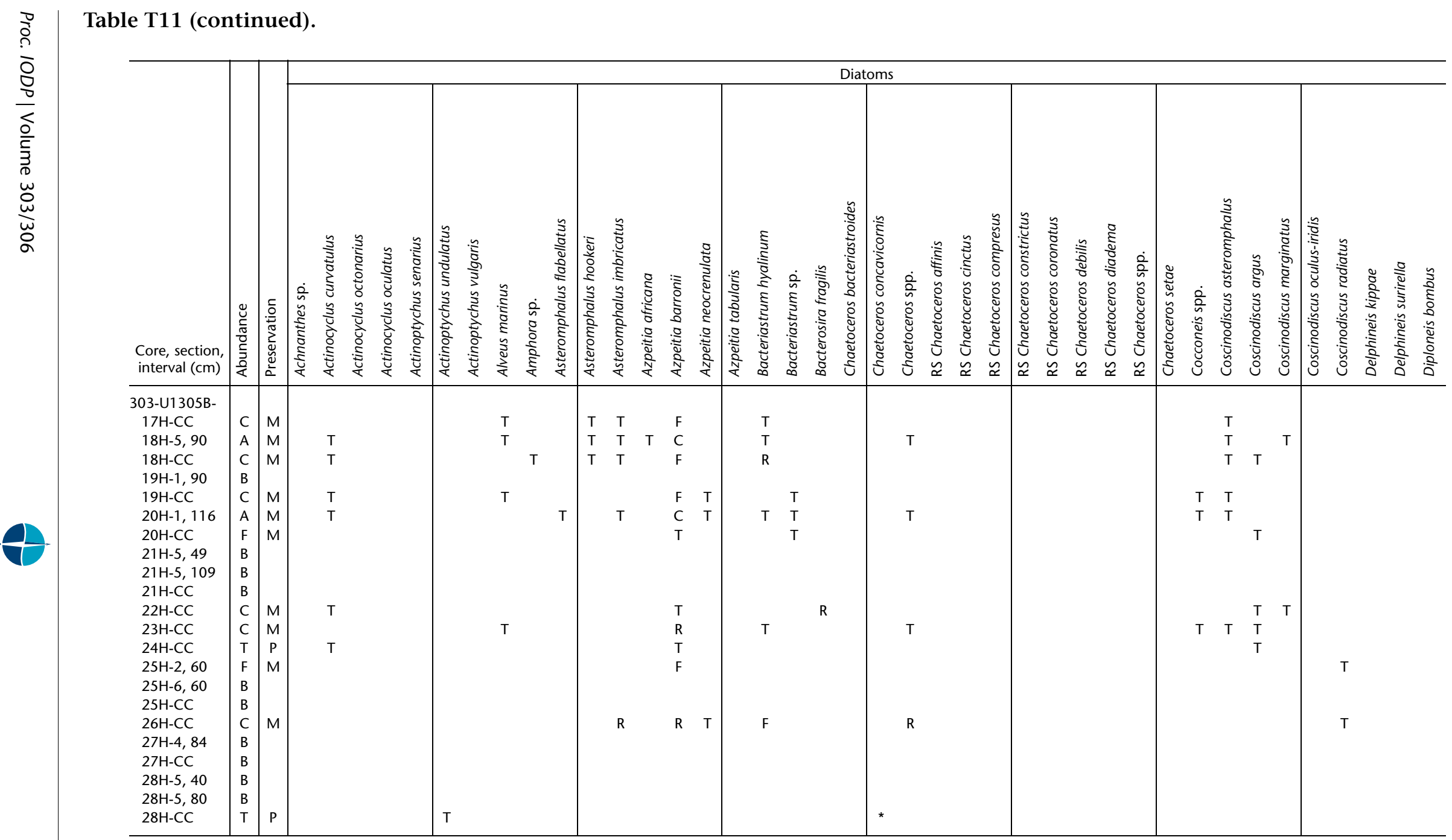

Notes: Abundance: $\mathrm{A}=$ abundant, $\mathrm{C}=$ common, $\mathrm{F}=$ few, $\mathrm{R}=$ rare, $\mathrm{T}=$ trace, $\mathrm{B}=$ barren. Preservation: $\mathrm{G}=$ good, $\mathrm{M}=$ moderate, $\mathrm{P}=$ poor. $\mathrm{RS}=$ resting spore. ${ }^{*}=$ fragment present. 

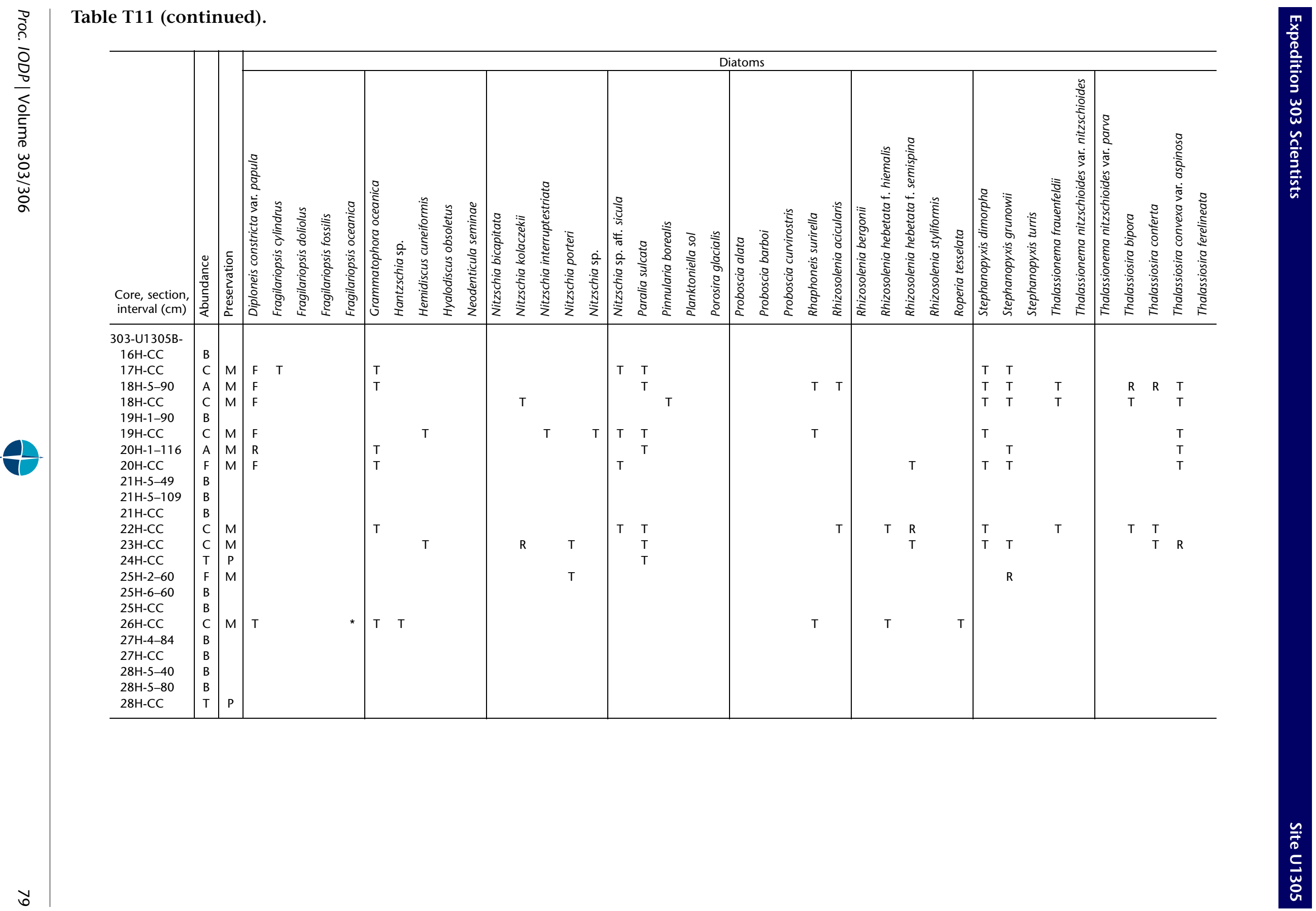


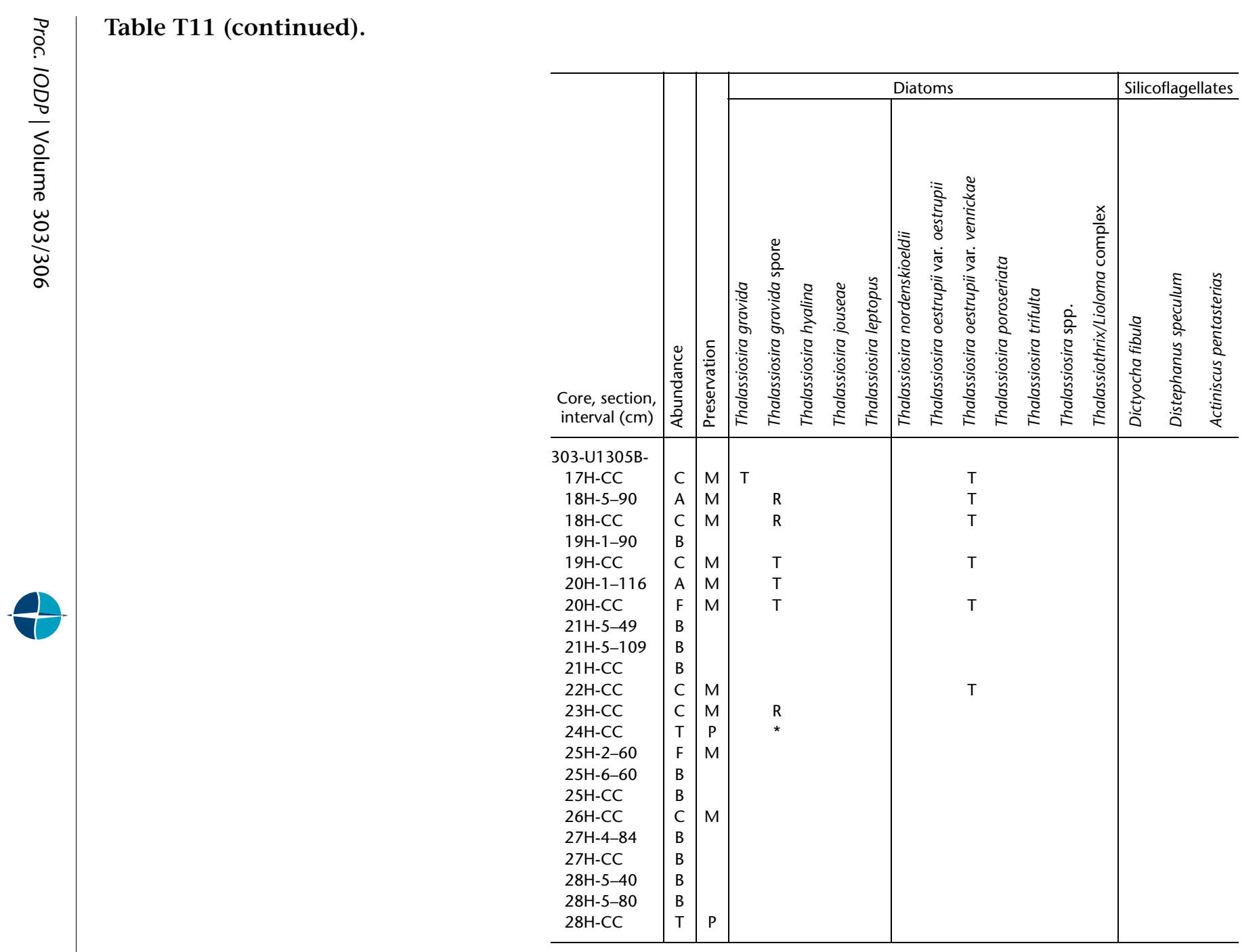



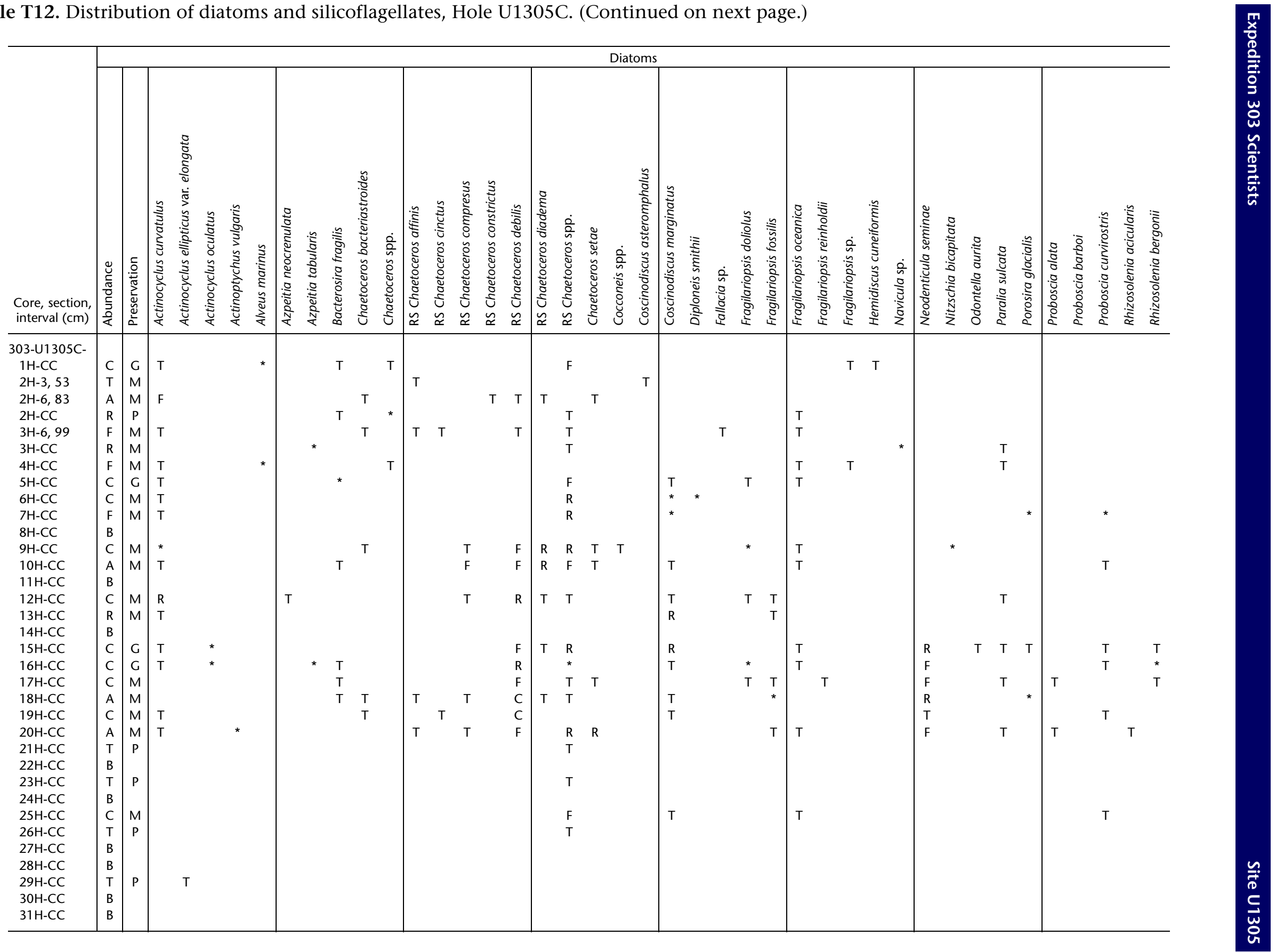

Notes: Abundance: $A=$ abundant,$C=$ common, $F=$ few, $R=$ rare, $T=$ trace, $B=$ barren. Preservation: $G=$ good, $M=$ moderate, $P=$ poor. $R S=$ resting spore. ${ }^{*}=$ fragment present. 

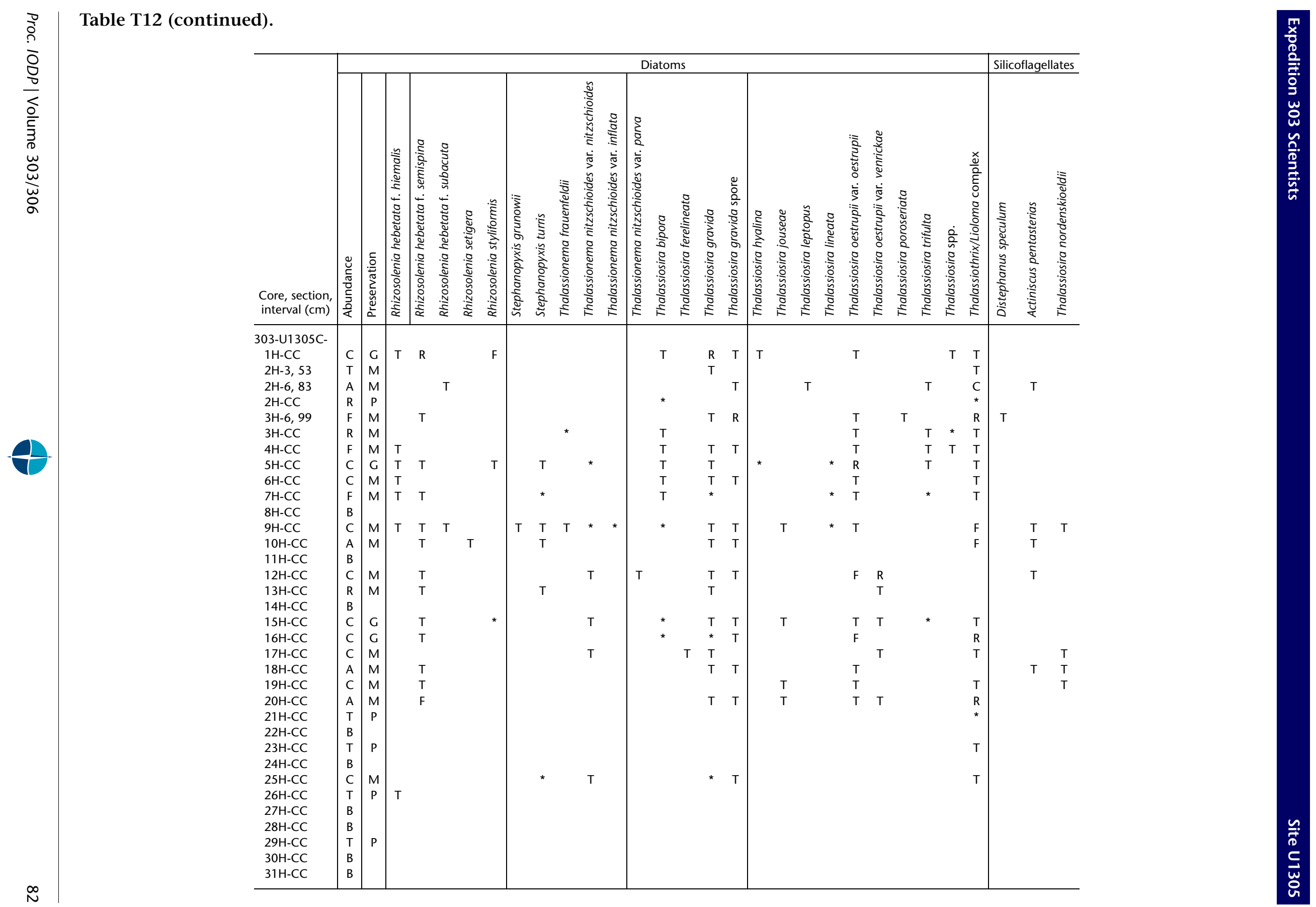
Table T13. Distribution of radiolarians, Holes U1305A and U1305B. (See table notes. Continued on next two pages.)

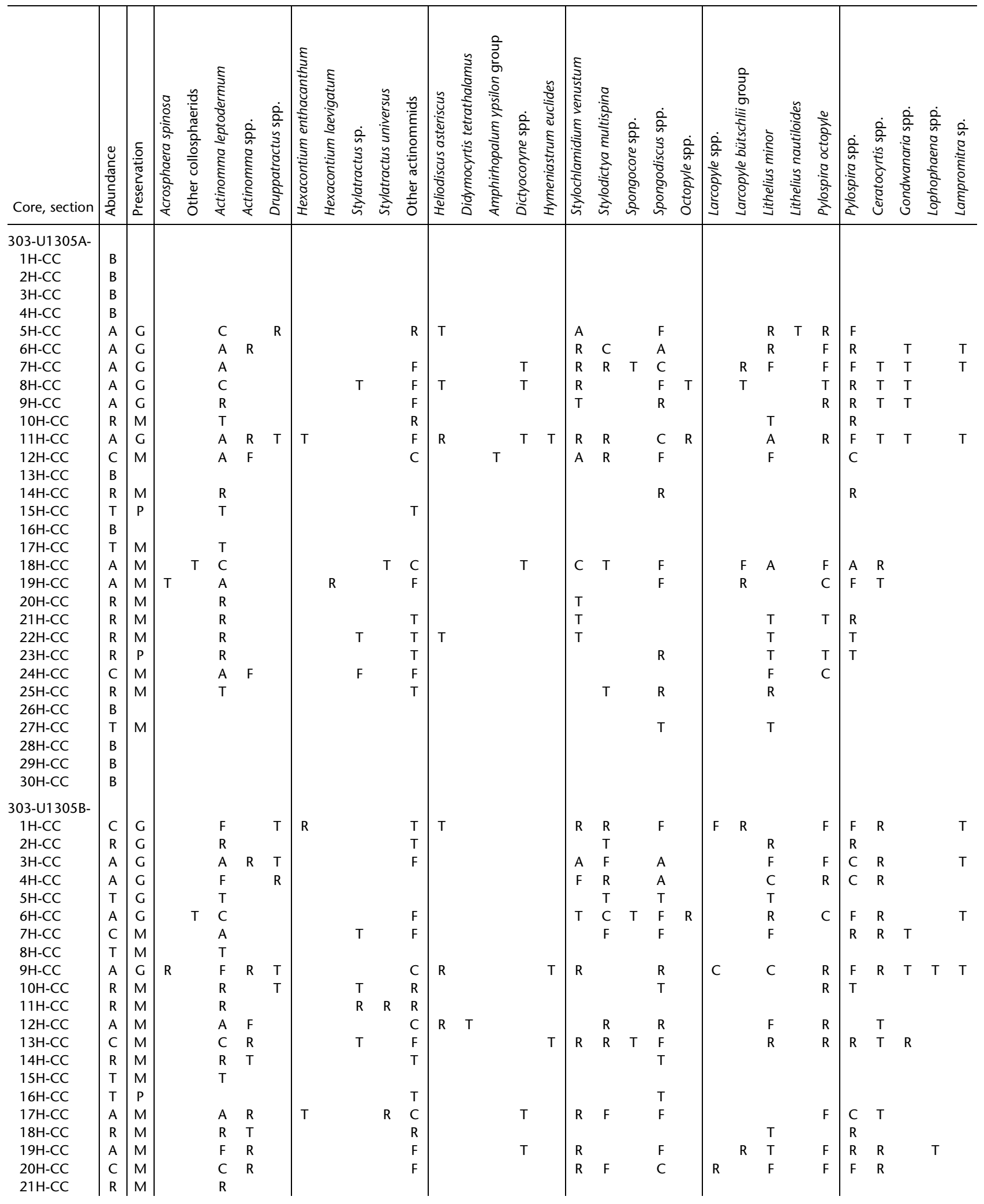


Table T13 (continued).

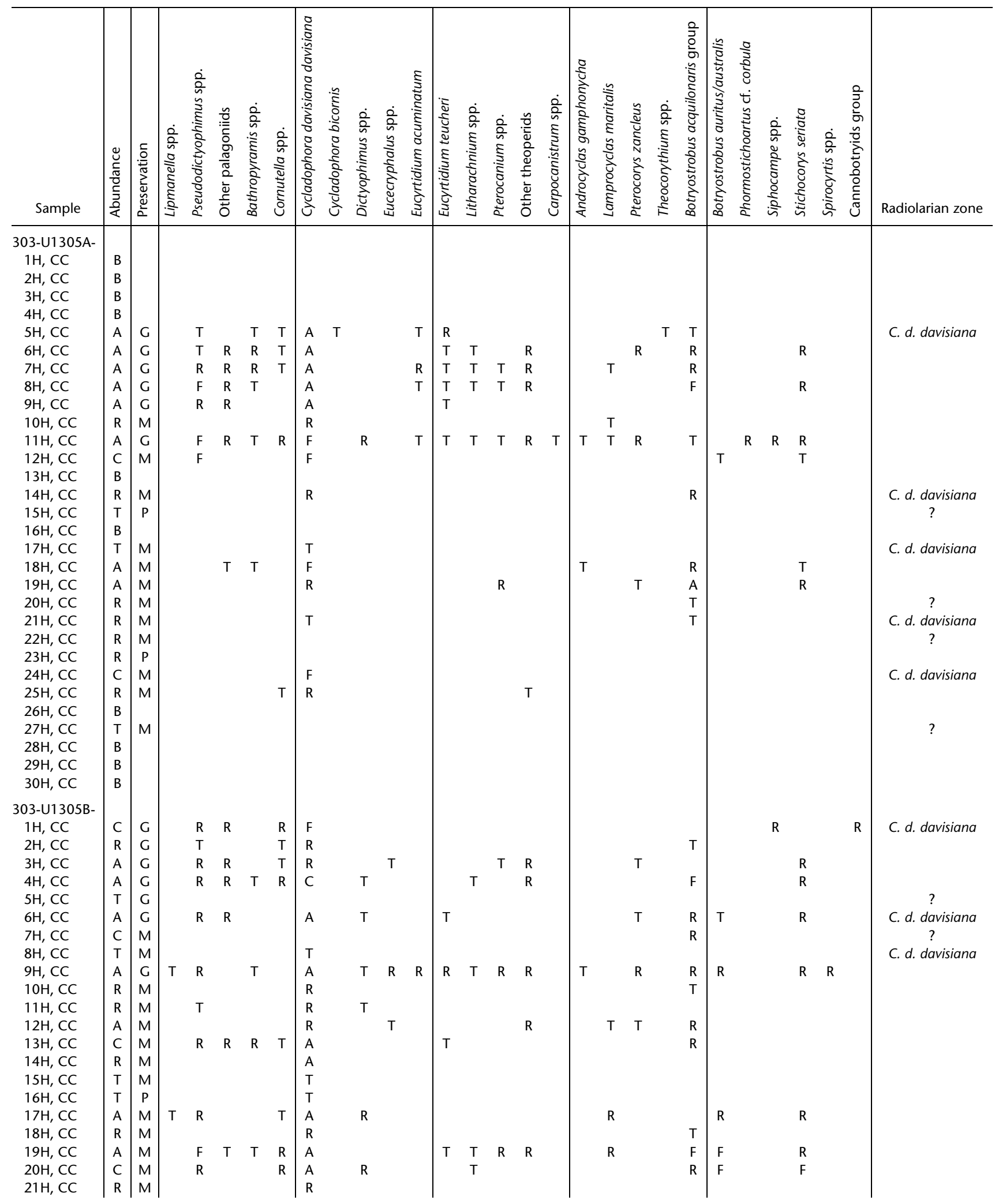


Table T13 (continued).

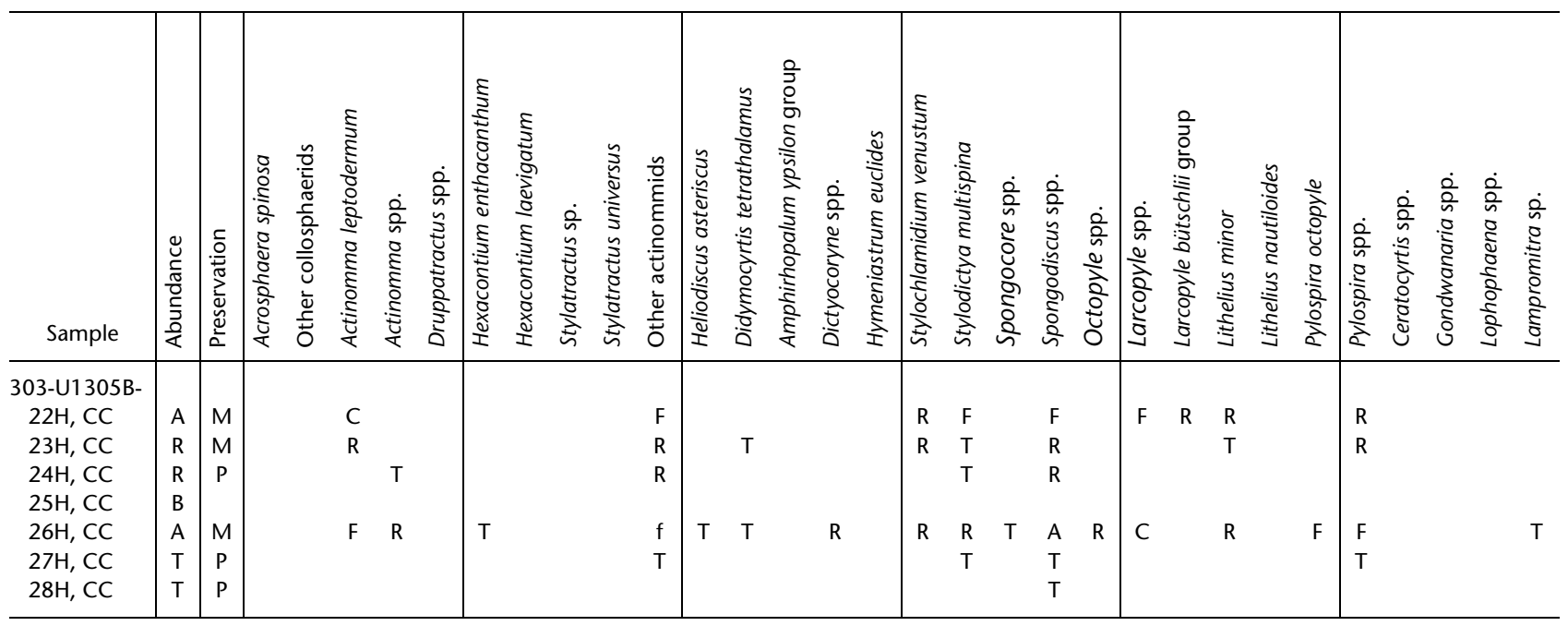

Notes: Abundance: $A=$ abundant, $C=$ common, $F=$ few, $R=$ rare, $T=$ trace, $B=$ barren (only in total abundance). Preservation: $\mathrm{G}=\mathrm{good}, \mathrm{M}=$ moderate, $\mathrm{P}=$ poor. Radiolarian zone per Goll and Bjørklund, 1989.

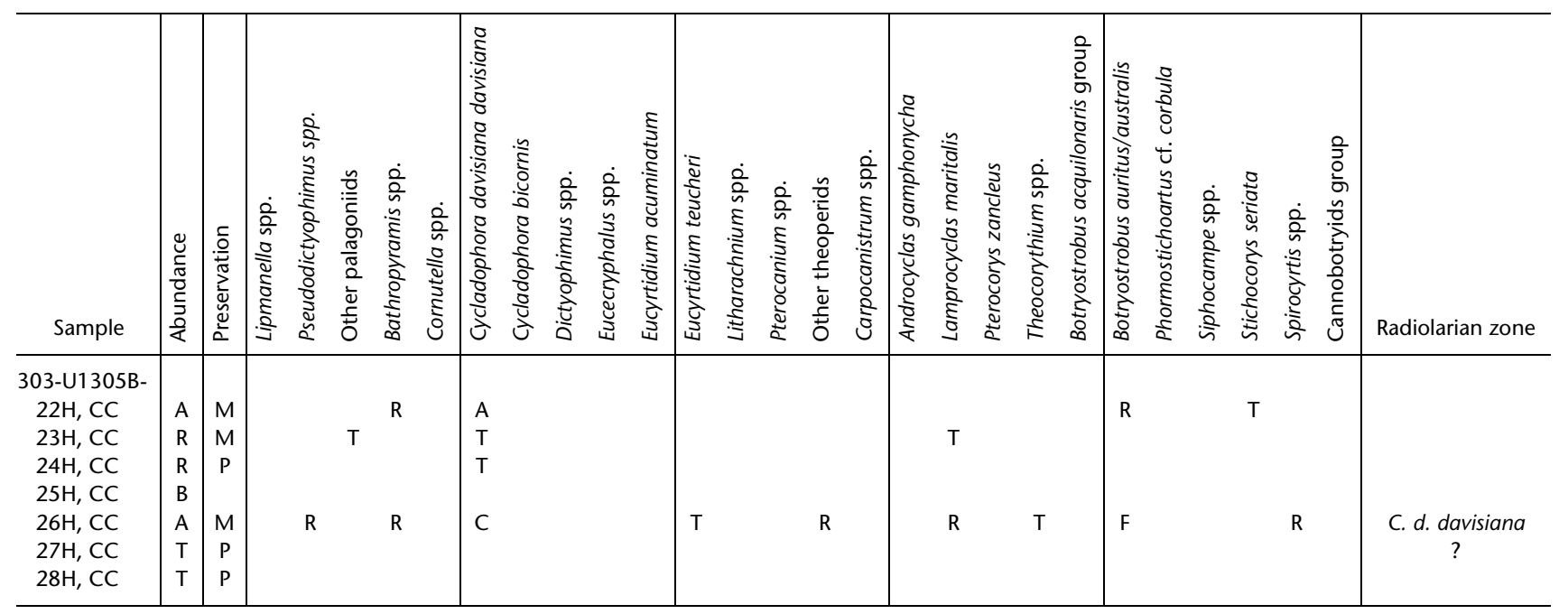




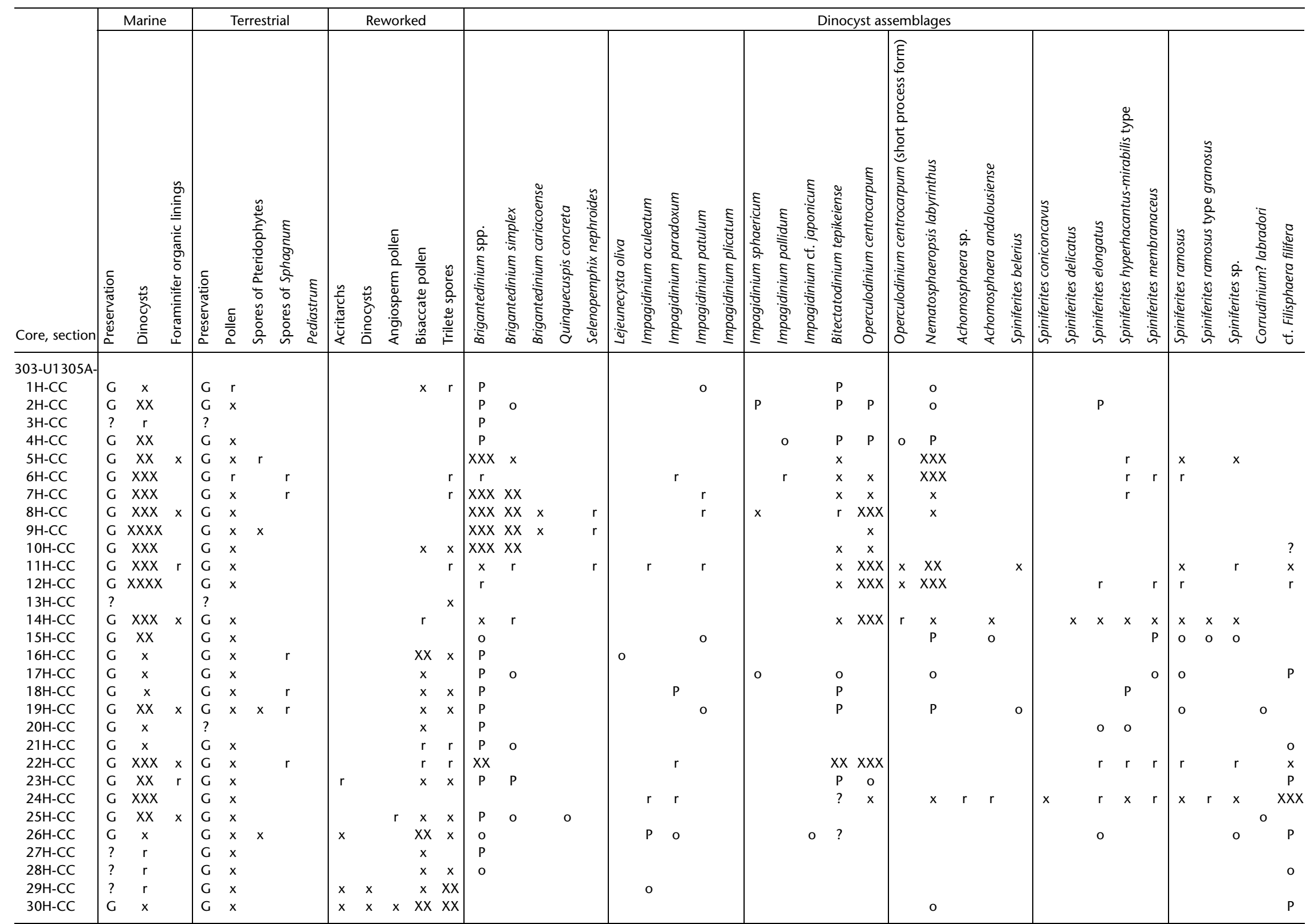

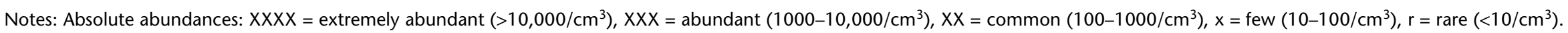
Relative abundance of dinocyst taxa: $X X X=$ dominant $(>30 \%), X X=$ common $(10 \%-30 \%), X=$ few $(2 \%-10 \%), r=$ rare $(<2 \%), P=$ presence $($ many specimens; counts $<50$ specimens), $0=$ single occurrence (counts $<50$ specimens). 
Table T15. Distribution of palynomorphs, Hole U1305C.

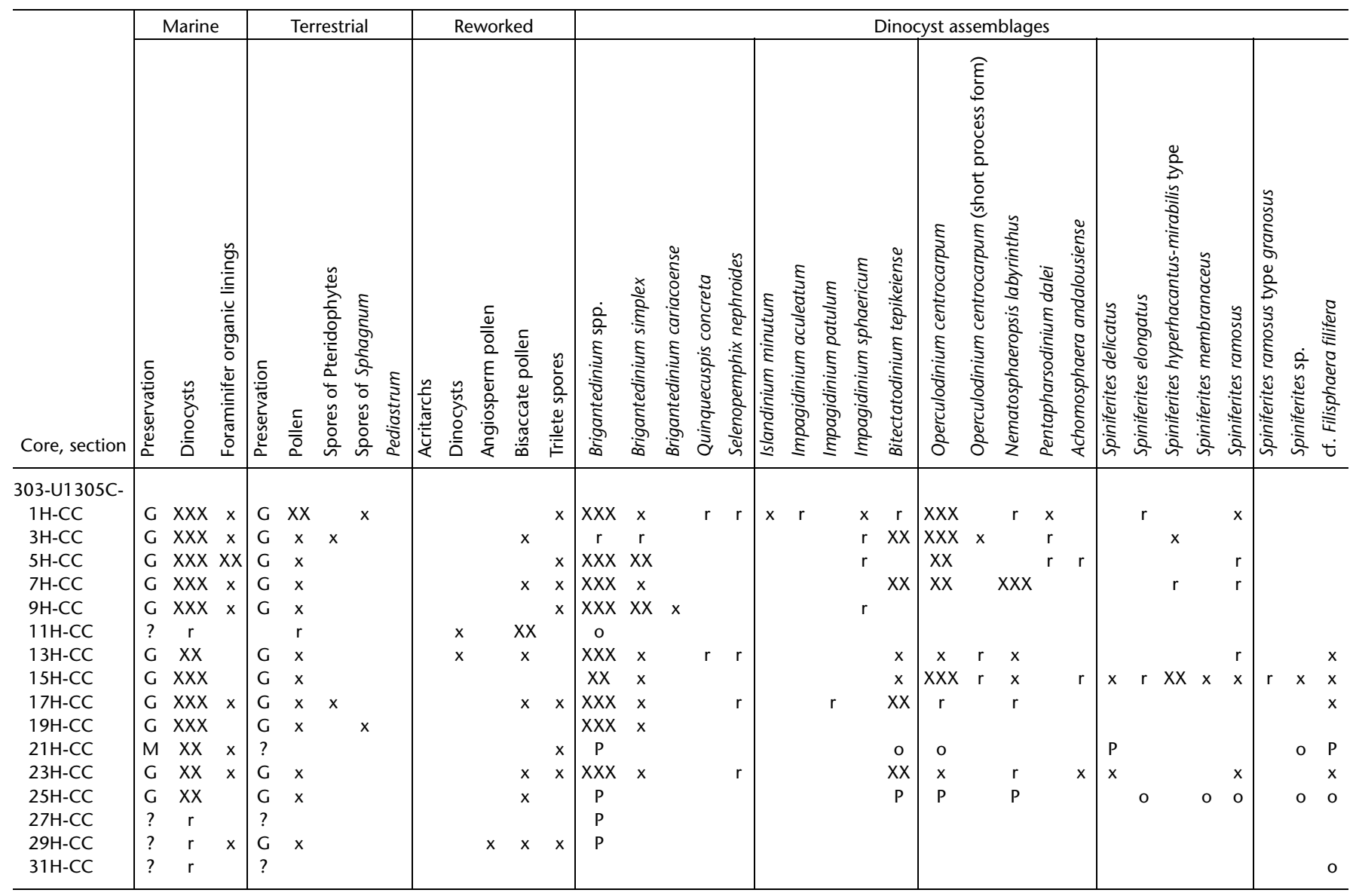

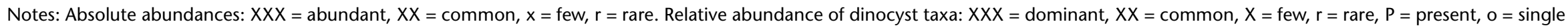
occurrence. 
Table T16. Polarity zonation, Holes U1305A, U1305B, and U1305C.

\begin{tabular}{|c|c|c|c|c|c|c|c|c|c|c|c|}
\hline \multirow[b]{2}{*}{ Polarity chron interpretation } & \multirow[b]{2}{*}{$\begin{array}{c}\text { Age } \\
\text { (Ma) }\end{array}$} & \multirow[b]{2}{*}{ Interval } & \multicolumn{3}{|c|}{ Hole U1305A } & \multicolumn{3}{|c|}{ Hole U1305B } & \multicolumn{3}{|c|}{ Hole U1305C } \\
\hline & & & $\begin{array}{c}\text { Core, section, } \\
\text { interval }(\mathrm{cm})\end{array}$ & $\begin{array}{l}\text { Depth } \\
\text { (mbsf) }\end{array}$ & $\begin{array}{l}\text { Depth } \\
\text { (mcd) }\end{array}$ & $\begin{array}{l}\text { Core, section, } \\
\text { interval }(\mathrm{cm})\end{array}$ & $\begin{array}{l}\text { Depth } \\
\text { (mbsf) }\end{array}$ & $\begin{array}{l}\text { Depth } \\
\text { (mcd) }\end{array}$ & $\begin{array}{l}\text { Core, section, } \\
\text { interval }(\mathrm{cm})\end{array}$ & $\begin{array}{l}\text { Depth } \\
\text { (mbsf) }\end{array}$ & $\begin{array}{l}\text { Depth } \\
\text { (mcd) }\end{array}$ \\
\hline \multirow{3}{*}{ C1n (b) Matuyama/Brunhes } & \multirow{3}{*}{0.78} & & 303-U1305A- & & & 303-U1305B- & & & 303-U1305C- & & \\
\hline & & Upper & $12 \mathrm{H}-6,20$ & 111.60 & 127.17 & $13 \mathrm{H}-2,80$ & 115.10 & 127.31 & $13 \mathrm{H}-4,105$ & 115.75 & 126.2 \\
\hline & & Lower & $12 \mathrm{H}-7,20$ & 113.10 & 128.67 & $13 \mathrm{H}-3,50$ & 116.30 & 128.51 & $13 \mathrm{H}-6,60$ & 118.30 & 128.75 \\
\hline \multirow[t]{2}{*}{ C1r.1n (t) Jaramillo } & \multirow[t]{2}{*}{0.99} & Upper & $15 \mathrm{H}-4,110$ & 138.00 & 156.21 & $15 \mathrm{H}-6,105^{*}$ & 140.45 & 153.82 & $16 \mathrm{H}-2,130$ & 141.50 & 156.05 \\
\hline & & Lower & $15 \mathrm{H} 5,90$ & 139.30 & 158.51 & $16 \mathrm{H}-2,50$ & 142.99 & 157.80 & $16 \mathrm{H}-4,5$ & 143.24 & 157.70 \\
\hline \multirow[t]{2}{*}{ C1r.1n (b) Jaramillo } & \multirow[t]{2}{*}{1.07} & Upper & $16 \mathrm{H}-5,25$ & 148.15 & 167.21 & $17 \mathrm{H}-1,70$ & 151.5 & 166.93 & $17 \mathrm{H}-3,20$ & 151.38 & 167.48 \\
\hline & & Lower & $16 \mathrm{H}-6,125$ & 150.65 & 169.71 & $17 \mathrm{H}-3,55$ & 154.3 & 169.70 & $17 \mathrm{H}-4,95$ & 153.62 & 169.72 \\
\hline \multirow[t]{2}{*}{ (b) Cobb Mountain } & \multirow[t]{2}{*}{1.20} & Upper & $20 \mathrm{H}-2,25$ & 181.66 & 205.30 & & & & $21 \mathrm{H}-2,95$ & 185.06 & 204.42 \\
\hline & & Lower & $20 \mathrm{H}-3,125$ & 184.18 & 207.82 & & & & $21 \mathrm{H}-4,100$ & 188.08 & 207.44 \\
\hline \multirow[t]{2}{*}{$\mathrm{C} 2 \mathrm{n}(\mathrm{t})$ Olduvai } & \multirow[t]{2}{*}{1.77} & Upper & $30 \mathrm{H}-2,70$ & 275.58 & 308.43 & & & & & & \\
\hline & & Lower & $30 \mathrm{H}-4,95$ & 278.84 & 311.69 & & & & & & \\
\hline
\end{tabular}

Note: $(\mathrm{t})=$ top,$(b)=$ bottom .

Table T17. Age interpretation, Site U1305.

\begin{tabular}{llll}
\hline \multirow{2}{*}{ Polarity chron interpretation } & \multirow{2}{*}{$\begin{array}{c}\text { Age } \\
\text { (Ma) }\end{array}$} & & \multicolumn{2}{c}{ Depth } \\
\cline { 3 - 4 } & & & \\
\hline C1n (b) Matuyama/Brunhes & 0.78 & 127.9 & 1 \\
C1r.1n (t) Jaramillo & 0.99 & 157.2 & 1.2 \\
C1r.1n (b) Jaramillo & 1.07 & 168.35 & 1.2 \\
Cobb Mountain & 1.2 & 205.9 & 1.5 \\
C2n (t) Olduvai & 1.77 & 310 & 1.6 \\
\hline
\end{tabular}

Note: $(b)=$ bottom, $(\mathrm{t})=$ top. 
Table T18. Shipboard composite and corrected composite depths, Holes U1305A, U1305B, and U1305C.

\begin{tabular}{|c|c|c|c|c|}
\hline \multirow[b]{2}{*}{ Core } & \multirow{2}{*}{$\begin{array}{l}\text { Top depth } \\
\text { (mbsf) }\end{array}$} & \multirow{2}{*}{$\begin{array}{l}\text { Offset } \\
(\mathrm{m})\end{array}$} & \multicolumn{2}{|c|}{ Top depth } \\
\hline & & & $(\mathrm{mcd})$ & (cmcd) \\
\hline \multicolumn{5}{|c|}{ 303-U1305A- } \\
\hline $1 \mathrm{H}$ & 0.00 & 3.88 & 3.88 & 3.53 \\
\hline $2 \mathrm{H}$ & 8.90 & 4.52 & 13.42 & 12.20 \\
\hline $3 \mathrm{H}$ & 18.40 & 5.51 & 23.91 & 21.74 \\
\hline $4 \mathrm{H}$ & 27.90 & 6.58 & 34.48 & 31.35 \\
\hline $5 \mathrm{H}$ & 37.40 & 7.31 & 44.71 & 40.65 \\
\hline $6 \mathrm{H}$ & 46.90 & 8.94 & 55.84 & 50.76 \\
\hline $7 \mathrm{H}$ & 56.40 & 10.19 & 66.59 & 60.54 \\
\hline $8 \mathrm{H}$ & 65.90 & 11.53 & 77.43 & 70.39 \\
\hline $9 \mathrm{H}$ & 75.40 & 12.60 & 88.00 & 80.00 \\
\hline $10 \mathrm{H}$ & 84.90 & 13.82 & 98.72 & 89.75 \\
\hline $11 \mathrm{H}$ & 94.40 & 14.49 & 108.89 & 98.99 \\
\hline $12 \mathrm{H}$ & 103.90 & 15.57 & 119.47 & 108.61 \\
\hline $13 \mathrm{H}$ & 113.40 & 16.80 & 130.20 & 118.36 \\
\hline $14 \mathrm{H}$ & 122.90 & 17.44 & 140.34 & 127.58 \\
\hline $15 \mathrm{H}$ & 132.40 & 18.21 & 150.61 & 136.92 \\
\hline $16 \mathrm{H}$ & 141.90 & 19.06 & 160.96 & 146.33 \\
\hline $17 \mathrm{H}$ & 151.40 & 19.58 & 170.98 & 155.44 \\
\hline $18 \mathrm{H}$ & 90 & 20.63 & 181.53 & 165.03 \\
\hline $19 \mathrm{H}$ & 170.40 & 21.38 & 191.78 & 174.35 \\
\hline $20 \mathrm{H}$ & 179.90 & 23.64 & 203.54 & 185.04 \\
\hline $21 \mathrm{H}$ & 189.40 & 24.32 & 213.72 & 194.29 \\
\hline $22 \mathrm{H}$ & 198.90 & 25.83 & 224.73 & 204.30 \\
\hline $23 \mathrm{H}$ & 208.40 & 26.19 & 234.59 & 213.26 \\
\hline $24 \mathrm{H}$ & 217.90 & 27.48 & 245.38 & 223.07 \\
\hline $25 \mathrm{H}$ & 227.40 & 27.71 & 255.11 & 231.92 \\
\hline $26 \mathrm{H}$ & 236.90 & 28.04 & 264.94 & 240.85 \\
\hline $27 \mathrm{H}$ & 246.40 & 28.53 & 274.93 & 249.94 \\
\hline $28 \mathrm{H}$ & 255.90 & 29.70 & 285.60 & 259.64 \\
\hline $29 \mathrm{H}$ & 265.40 & 29.70 & 295.10 & 268.27 \\
\hline $30 \mathrm{H}$ & 273.40 & 32.85 & 306.25 & 278.41 \\
\hline \multicolumn{5}{|c|}{ 303-U1305B- } \\
\hline $1 \mathrm{H}$ & 0.00 & 0.00 & 0.00 & 0.00 \\
\hline $2 \mathrm{H}$ & 8.30 & 0.62 & 8.92 & 8.11 \\
\hline $3 \mathrm{H}$ & 17.80 & 1.63 & 19.43 & 17.66 \\
\hline $4 \mathrm{H}$ & 27.30 & 2.89 & 30.19 & 27.45 \\
\hline $5 \mathrm{H}$ & 36.80 & 3.80 & 40.60 & 36.91 \\
\hline $6 \mathrm{H}$ & 46.30 & 5.60 & 51.90 & 47.18 \\
\hline $7 \mathrm{H}$ & 55.80 & 6.55 & 62.35 & 56.68 \\
\hline $8 \mathrm{H}$ & 530 & 7.63 & 72.93 & 66.30 \\
\hline $9 \mathrm{H}$ & 74.80 & 8.71 & 83.51 & 75.92 \\
\hline $10 \mathrm{H}$ & 84.30 & 9.35 & 93.65 & 85.14 \\
\hline $11 \mathrm{H}$ & 93.80 & 10.35 & 104.15 & 94.68 \\
\hline $12 \mathrm{H}$ & 103.30 & 10.86 & 114.16 & 103.78 \\
\hline $13 \mathrm{H}$ & 112.80 & 12.21 & 125.01 & 113.65 \\
\hline $14 \mathrm{H}$ & 122.30 & 12.44 & 134.74 & 122.49 \\
\hline
\end{tabular}

\begin{tabular}{|c|c|c|c|c|}
\hline \multirow[b]{2}{*}{ Core } & \multirow{2}{*}{$\begin{array}{c}\text { Top depth } \\
\text { (mbsf) }\end{array}$} & \multirow{2}{*}{$\begin{array}{l}\text { Offset } \\
(\mathrm{m})\end{array}$} & \multicolumn{2}{|c|}{ Top depth } \\
\hline & & & $(\mathrm{mcd})$ & $(\mathrm{cmcd})$ \\
\hline $15 \mathrm{H}$ & 131.80 & 13.37 & 145.17 & 131.97 \\
\hline $16 \mathrm{H}$ & 141.30 & 14.51 & 155.81 & 141.65 \\
\hline $17 \mathrm{H}$ & 150.80 & 15.40 & 166.20 & 151.09 \\
\hline $18 \mathrm{H}$ & 160.30 & 16.30 & 176.60 & 160.55 \\
\hline $19 \mathrm{H}$ & 169.80 & 17.38 & 187.18 & 170.16 \\
\hline $20 \mathrm{H}$ & 179.30 & 18.49 & 197.79 & 179.81 \\
\hline $21 \mathrm{H}$ & 188.80 & 20.61 & 209.41 & 190.37 \\
\hline $22 \mathrm{H}$ & 198.30 & 20.98 & 219.28 & 199.35 \\
\hline $23 \mathrm{H}$ & 207.80 & 22.07 & 229.87 & 208.97 \\
\hline $24 \mathrm{H}$ & 217.30 & 22.83 & 240.13 & 218.30 \\
\hline $25 \mathrm{H}$ & 226.80 & 23.92 & 250.72 & 227.93 \\
\hline $26 \mathrm{H}$ & 236.30 & 24.68 & 260.98 & 237.25 \\
\hline $27 \mathrm{H}$ & 245.80 & 25.44 & 271.24 & 246.58 \\
\hline $28 \mathrm{H}$ & 255.30 & 26.10 & 281.40 & 255.82 \\
\hline \multicolumn{5}{|c|}{ 303-U1305C- } \\
\hline $1 \mathrm{H}$ & 0.00 & 0.05 & 0.05 & 0.05 \\
\hline $2 \mathrm{H}$ & 5.70 & 0.93 & 6.63 & 6.03 \\
\hline $3 \mathrm{H}$ & 15.20 & 1.98 & 17.18 & 15.62 \\
\hline $4 \mathrm{H}$ & 24.70 & 3.39 & 28.09 & 25.54 \\
\hline $5 \mathrm{H}$ & 34.20 & 3.64 & 37.84 & 34.40 \\
\hline $6 \mathrm{H}$ & 43.70 & 3.89 & 47.59 & 43.26 \\
\hline $7 \mathrm{H}$ & 53.20 & 5.57 & 58.77 & 53.43 \\
\hline $8 \mathrm{H}$ & 62.70 & 6.47 & 69.17 & 62.88 \\
\hline $9 \mathrm{H}$ & 72.20 & 7.01 & 79.21 & 72.01 \\
\hline $10 \mathrm{H}$ & 81.70 & 7.17 & 88.87 & 80.79 \\
\hline $11 \mathrm{H}$ & 91.20 & 7.99 & 99.19 & 90.17 \\
\hline $12 \mathrm{H}$ & 100.70 & 9.20 & 109.90 & 99.91 \\
\hline $13 \mathrm{H}$ & 110.20 & 10.45 & 120.65 & 109.68 \\
\hline $14 \mathrm{H}$ & 119.70 & 11.66 & 131.36 & 119.42 \\
\hline $15 \mathrm{H}$ & 129.20 & 12.93 & 142.13 & 129.21 \\
\hline $16 \mathrm{H}$ & 138.70 & 14.55 & 153.25 & 139.32 \\
\hline $17 \mathrm{H}$ & 148.20 & 16.10 & 164.30 & 149.36 \\
\hline $18 \mathrm{H}$ & 157.70 & 15.83 & 173.53 & 157.75 \\
\hline $19 \mathrm{H}$ & 167.20 & 16.20 & 183.40 & 166.73 \\
\hline $20 \mathrm{H}$ & 173.10 & 17.86 & 190.96 & 173.60 \\
\hline $21 \mathrm{H}$ & 182.60 & 19.36 & 201.96 & 183.60 \\
\hline $22 \mathrm{H}$ & 192.10 & 19.81 & 211.91 & 192.65 \\
\hline $23 \mathrm{H}$ & 201.60 & 20.84 & 222.44 & 202.22 \\
\hline $24 \mathrm{H}$ & 211.10 & 21.47 & 232.57 & 211.43 \\
\hline $25 \mathrm{H}$ & 220.60 & 22.84 & 243.44 & 221.31 \\
\hline $26 \mathrm{H}$ & 230.10 & 24.16 & 254.26 & 231.15 \\
\hline $27 \mathrm{H}$ & 239.60 & 25.26 & 264.86 & 240.78 \\
\hline $28 \mathrm{H}$ & 249.10 & 25.70 & 274.80 & 249.82 \\
\hline $29 \mathrm{H}$ & 258.60 & 27.46 & 286.06 & 260.05 \\
\hline $30 \mathrm{H}$ & 268.10 & 26.32 & 294.42 & 267.65 \\
\hline $31 \mathrm{H}$ & 277.60 & 26.32 & 303.92 & 276.29 \\
\hline
\end{tabular}


Table T19. Sampling splice tie points, Site U1305.

\begin{tabular}{|c|c|c|c|c|c|c|}
\hline \multirow{2}{*}{$\begin{array}{l}\text { Hole, core, section, } \\
\text { interval }(\mathrm{cm})\end{array}$} & \multicolumn{2}{|c|}{ Depth } & & \multirow{2}{*}{$\begin{array}{l}\text { Hole, core, section, } \\
\text { interval }(\mathrm{cm})\end{array}$} & \multicolumn{2}{|c|}{ Depth } \\
\hline & mbsf & $\mathrm{mcd}$ & & & mbsf & mcd \\
\hline 1305B-1H-6, 3.70 & 7.54 & 7.54 & Tie to & $1305 \mathrm{~A}-1 \mathrm{H}-3,63.30$ & 3.66 & 7.54 \\
\hline $1305 \mathrm{~A}-1 \mathrm{H}-5,41.50$ & 6.42 & 10.30 & Tie to & $1305 \mathrm{~B}-2 \mathrm{H}-1,138.00$ & 9.68 & 10.30 \\
\hline 1305B-2H-5, 101.70 & 15.32 & 15.94 & Tie to & $1305 \mathrm{~A}-2 \mathrm{H}-2,101.50$ & 11.42 & 15.94 \\
\hline $1305 \mathrm{~A}-2 \mathrm{H}-6,89.50$ & 17.30 & 21.82 & Tie to & $1305 \mathrm{~B}-3 \mathrm{H}-2,89.30$ & 20.19 & 21.82 \\
\hline $1305 \mathrm{~B}-3 \mathrm{H}-5,32.70$ & 24.13 & 25.76 & Tie to & $1305 \mathrm{~A}-3 \mathrm{H}-2,35.30$ & 20.25 & 25.76 \\
\hline $1305 \mathrm{~A}-3 \mathrm{H}-7,3.90$ & 27.44 & 32.95 & Tie to & 1305B-4H-2, 125.50 & 30.06 & 32.95 \\
\hline 1305B-4H-5, 111.40 & 34.41 & 37.30 & Tie to & $1305 \mathrm{~A}-4 \mathrm{H}-2,131.60$ & 30.72 & 37.30 \\
\hline 1305A-4H-6, 138.10 & 36.78 & 43.36 & Tie to & 1305B-5H-2, 125.50 & 39.56 & 43.36 \\
\hline $1305 \mathrm{~B}-5 \mathrm{H}-5,57.40$ & 43.37 & 47.17 & Tie to & $1305 \mathrm{~A}-5 \mathrm{H}-2,96.20$ & 39.86 & 47.17 \\
\hline $1305 \mathrm{~A}-5 \mathrm{H}-6,82.30$ & 45.72 & 53.03 & Tie to & $1305 \mathrm{C}-6 \mathrm{H}-4,93.80$ & 49.14 & 53.03 \\
\hline $1305 \mathrm{C}-6 \mathrm{H}-6,51.40$ & 51.71 & 55.60 & Tie to & $1305 \mathrm{~B}-6 \mathrm{H}-3,68.60$ & 50.00 & 55.60 \\
\hline 1305B-6H-4, 113.20 & 51.93 & 57.53 & Tie to & $1305 \mathrm{~A}-6 \mathrm{H}-2,16.10$ & 48.59 & 57.53 \\
\hline $1305 \mathrm{~A}-6 \mathrm{H}-6,39.00$ & 54.79 & 63.73 & Tie to & 1305B-7H-1, 138.00 & 57.18 & 63.73 \\
\hline 1305B-7H-5, 136.40 & 63.10 & 69.65 & Tie to & $1305 \mathrm{~A}-7 \mathrm{H}-3,5.80$ & 59.46 & 69.65 \\
\hline 1305A-7H-6, 136.30 & 65.26 & 75.45 & Tie to & 1305B-8H-2, 101.80 & 67.82 & 75.45 \\
\hline 1305B-8H-5, 149.10 & 72.79 & 80.42 & Tie to & $1305 \mathrm{~A}-8 \mathrm{H}-2,148.90$ & 68.89 & 80.42 \\
\hline $1305 \mathrm{~A}-8 \mathrm{H}-6,61.10$ & 74.01 & 85.54 & Tie to & 1305B-9H-2, 52.20 & 76.83 & 85.54 \\
\hline $1305 \mathrm{~B}-9 \mathrm{H}-6,60.00$ & 82.90 & 91.61 & Tie to & $1305 \mathrm{~A}-9 \mathrm{H}-3,59.20$ & 79.01 & 91.61 \\
\hline $1305 \mathrm{~A}-9 \mathrm{H}-6,36.40$ & 83.26 & 95.86 & Tie to & 1305B-10H-2, 71.20 & 86.51 & 95.86 \\
\hline 1305B-10H-6, 110.30 & 92.90 & 102.25 & Tie to & $1305 \mathrm{~A}-10 \mathrm{H}-3,52.90$ & 88.43 & 102.25 \\
\hline $1305 \mathrm{~A}-10 \mathrm{H}-6,66.70$ & 93.07 & 106.89 & Tie to & $1305 \mathrm{~B}-11 \mathrm{H}-2,125.10$ & 96.54 & 106.89 \\
\hline 1305B-11H-6, 131.00 & 102.60 & 112.95 & Tie to & $1305 \mathrm{C}-12 \mathrm{H}-3,5.30$ & 103.75 & 112.95 \\
\hline $1305 \mathrm{C}-12 \mathrm{H}-6,136.20$ & 109.56 & 118.76 & Tie to & 1305B-12H-4, 15.00 & 107.90 & 118.76 \\
\hline $1305 \mathrm{~B}-12 \mathrm{H}-6,14.80$ & 110.89 & 121.75 & Tie to & $1305 \mathrm{~A}-12 \mathrm{H}-2,75.80$ & 106.18 & 121.75 \\
\hline $1305 \mathrm{~A}-12 \mathrm{H}-5,41.30$ & 110.31 & 125.88 & Tie to & 1305B-13H-1, 85.50 & 113.67 & 125.88 \\
\hline 1305B-13H-6, 16.80 & 120.52 & 132.73 & Tie to & $1305 \mathrm{C}-14 \mathrm{H}-1,136.50$ & 121.07 & 132.73 \\
\hline $1305 \mathrm{C}-14 \mathrm{H}-7,18.90$ & 128.89 & 140.55 & Tie to & $1305 \mathrm{~B}-14 \mathrm{H}-4,127.30$ & 128.11 & 140.55 \\
\hline $1305 \mathrm{~B}-14 \mathrm{H}-6,24.70$ & 130.12 & 142.56 & Tie to & $1305 \mathrm{~A}-14 \mathrm{H}-2,69.30$ & 125.12 & 142.56 \\
\hline $1305 \mathrm{~A}-14 \mathrm{H}-5,147.00$ & 130.37 & 147.81 & Tie to & 1305B-15H-2, 113.30 & 134.44 & 147.81 \\
\hline 1305B-15H-6, 57.10 & 139.97 & 153.34 & Tie to & $1305 \mathrm{~A}-15 \mathrm{H}-2,122.30$ & 135.13 & 153.34 \\
\hline $1305 \mathrm{~A}-15 \mathrm{H}-6,2.40$ & 139.92 & 158.13 & Tie to & 1305B-16H-2, 82.00 & 143.62 & 158.13 \\
\hline 1305B-16H-5, 10.20 & 147.48 & 161.99 & Tie to & $1305 \mathrm{~A}-16 \mathrm{H}-1,100.50$ & 142.93 & 161.99 \\
\hline $1305 \mathrm{~A}-16 \mathrm{H}-7,24.00$ & 151.14 & 170.20 & Tie to & 1305B-17H-3, 104.30 & 154.80 & 170.20 \\
\hline 1305B-17H-6, 43.30 & 158.64 & 174.04 & Tie to & $1305 \mathrm{~A}-17 \mathrm{H}-3,4.10$ & 154.46 & 174.04 \\
\hline $1305 \mathrm{~A}-17 \mathrm{H}-6,130.40$ & 160.20 & 179.78 & Tie to & 1305B-18H-3, 19.50 & 163.48 & 179.78 \\
\hline 1305B-18H-5, 71.10 & 166.98 & 183.28 & Tie to & $1305 \mathrm{~A}-18 \mathrm{H}-2,22.80$ & 162.65 & 183.28 \\
\hline $1305 \mathrm{~A}-18 \mathrm{H}-6,80.00$ & 169.22 & 189.85 & Tie to & $1305 \mathrm{~B}-19 \mathrm{H}-2,120.00$ & 172.47 & 189.85 \\
\hline 1305B-19H-4, 98.40 & 175.19 & 192.57 & Tie to & $1305 \mathrm{C}-20 \mathrm{H}-2,15.30$ & 174.71 & 192.57 \\
\hline $1305 \mathrm{C}-20 \mathrm{H}-7,42.20$ & 182.49 & 200.35 & Tie to & $1305 \mathrm{~B}-20 \mathrm{H}-2,146.40$ & 181.86 & 200.35 \\
\hline 1305B-20H-4, 139.60 & 184.01 & 202.50 & Tie to & $1305 \mathrm{C}-21 \mathrm{H}-1,54.00$ & 183.14 & 202.50 \\
\hline $1305 \mathrm{C}-21 \mathrm{H}-6,74.10$ & 190.81 & 210.70 & Tie to & $1305 \mathrm{~A}-20 \mathrm{H}-5,53.70$ & 186.51 & 210.17 \\
\hline $1305 \mathrm{~A}-20 \mathrm{H}-7,1.90$ & 189.07 & 212.71 & Tie to & $1305 \mathrm{C}-22 \mathrm{H}-1,78.00$ & 192.90 & 212.71 \\
\hline $1305 \mathrm{C}-22 \mathrm{H}-6,143.00$ & 201.03 & 220.84 & Tie to & $1305 \mathrm{~B}-22 \mathrm{H}-2,9.10$ & 199.86 & 220.84 \\
\hline 1305B-22H-6, 22.40 & 205.90 & 226.88 & Tie to & $1305 \mathrm{~A}-22 \mathrm{H}-2,65.40$ & 201.05 & 226.88 \\
\hline $1305 \mathrm{~A}-22 \mathrm{H}-7,52.20$ & 208.30 & 234.13 & Tie to & $1305 \mathrm{~B}-23 \mathrm{H}-3,129.50$ & 212.06 & 234.13 \\
\hline 1305В-23Н-7, 19.80 & 216.89 & 238.96 & Tie to & $1305 \mathrm{~A}-23 \mathrm{H}-3,127.90$ & 212.77 & 238.96 \\
\hline $1305 \mathrm{~A}-23 \mathrm{H}-6,123.10$ & 217.28 & 243.47 & Tie to & $1305 \mathrm{~B}-24 \mathrm{H}-3,33.10$ & 220.64 & 243.47 \\
\hline 1305B-24H-5, 43.20 & 223.69 & 246.52 & Tie to & $1305 \mathrm{~A}-24 \mathrm{H}-1,114.00$ & 219.04 & 246.52 \\
\hline $1305 \mathrm{~A}-24 \mathrm{H}-5,134.10$ & 225.16 & 252.64 & Tie to & $1305 \mathrm{~B}-25 \mathrm{H}-2,43.80$ & 228.72 & 252.64 \\
\hline $1305 \mathrm{~B}-25 \mathrm{H}-5,77.50$ & 233.52 & 257.44 & Tie to & $1305 \mathrm{~A}-25 \mathrm{H}-2,80.10$ & 229.73 & 257.44 \\
\hline $1305 \mathrm{~A}-25 \mathrm{H}-6,122.50$ & 236.10 & 263.81 & Tie to & $1305 \mathrm{~B}-26 \mathrm{H}-2,132.80$ & 239.13 & 263.81 \\
\hline $1305 \mathrm{~B}-26 \mathrm{H}-5,3.80$ & 242.36 & 267.04 & Tie to & $1305 \mathrm{~A}-26 \mathrm{H}-2,62.10$ & 239.00 & 267.04 \\
\hline $1305 \mathrm{~A}-26 \mathrm{H}-5,106.00$ & 243.92 & 271.96 & Tie to & 1305B-27Н-1, 72.00 & 246.52 & 271.96 \\
\hline 1305B-27H-4, 97.10 & 250.43 & 275.87 & Tie to & $1305 \mathrm{~A}-27 \mathrm{H}-1,93.00$ & 247.34 & 275.87 \\
\hline $1305 \mathrm{~A}-27 \mathrm{H}-6,80.60$ & 254.55 & 283.08 & Tie to & 1305B-28H-2, 17.30 & 256.98 & 283.08 \\
\hline 1305B-28H-6, 115.30 & 263.92 & 290.02 & Tie to & $1305 \mathrm{~A}-28 \mathrm{H}-3,141.10$ & 260.32 & 290.02 \\
\hline $1305 \mathrm{~A}-28 \mathrm{H}-7,80.00$ & 265.64 & 295.34 & Tie to & $1305 \mathrm{~A}-29 \mathrm{H}-1,23.50$ & 265.64 & 295.34 \\
\hline $1305 \mathrm{~A}-29 \mathrm{H}-6,62.00$ & 273.42 & 303.12 & Append to & $1305 \mathrm{C}-31 \mathrm{H}-1,0.00$ & 277.60 & 303.92 \\
\hline $1305 \mathrm{C}-31 \mathrm{H}-7,121.00$ & 287.61 & 313.93 & & & & \\
\hline
\end{tabular}


Table T20. Depth ranges and sedimentation rates, Site U1305.

\begin{tabular}{cc}
\hline $\begin{array}{c}\text { Depth interval } \\
(\mathrm{mcd})\end{array}$ & $\begin{array}{c}\text { Sedimentation } \\
\text { rate (cm/k.y.) }\end{array}$ \\
\hline $0-128.3$ & 16.5 \\
$128.3-157.2$ & 13.8 \\
$157.2-168.4$ & 14.0 \\
$168.4-203.5$ & 29.3 \\
$203.5-207.2$ & 14.6 \\
$207.2-310.0$ & 18.5 \\
\hline
\end{tabular}

Table T21. Headspace hydrocarbon gases, Hole U1305A.

\begin{tabular}{|c|c|c|c|c|c|}
\hline $\begin{array}{l}\text { Core, section, } \\
\text { interval }(\mathrm{cm})\end{array}$ & $\begin{array}{l}\text { Depth } \\
\text { (mbsf) }\end{array}$ & $\begin{array}{l}\mathrm{C}_{1} / \mathrm{C}_{2} \\
\text { ratio }\end{array}$ & $\begin{array}{c}\mathrm{C}_{1} \\
\text { (ppmv) }\end{array}$ & $\begin{array}{c}\mathrm{C}_{2} \\
(\mathrm{ppmv})\end{array}$ & $\begin{array}{c}\mathrm{C}_{2=} \\
(\mathrm{ppmv})\end{array}$ \\
\hline \multicolumn{6}{|l|}{ 303-U1305A- } \\
\hline $1 \mathrm{H}-2,0-5$ & 1.50 & & 4 & 0.0 & 0.0 \\
\hline $2 \mathrm{H}-2,0-5$ & 10.40 & & 3 & 0.0 & 0.0 \\
\hline $3 \mathrm{H}-2,0-5$ & 19.90 & & 5 & 0.0 & 0.0 \\
\hline $4 \mathrm{H}-2,0-5$ & 29.40 & & 13 & 0.0 & 0.0 \\
\hline $5 \mathrm{H}-2,0-5$ & 38.90 & & 21 & 0.0 & 0.0 \\
\hline $6 \mathrm{H}-2,0-5$ & 48.40 & & 19 & 0.0 & 0.0 \\
\hline $7 \mathrm{H}-2,0-5$ & 57.90 & & 1,816 & 0.0 & 0.0 \\
\hline $8 \mathrm{H}-2,0-5$ & 67.40 & & 7,971 & 0.0 & 0.0 \\
\hline $9 \mathrm{H}-2,0-5$ & 76.90 & 7,328 & 14,656 & 2.0 & 0.0 \\
\hline $10 \mathrm{H}-2,0-5$ & 86.40 & 7,574 & 20,449 & 2.7 & 0.0 \\
\hline $11 \mathrm{H}-2,0-5$ & 95.90 & 6,895 & 24,132 & 3.5 & 0.0 \\
\hline $12 \mathrm{H}-2,0-5$ & 105.40 & 5,969 & 22,681 & 3.8 & 0.0 \\
\hline $13 \mathrm{H}-2,0-5$ & 114.90 & 6,160 & 33,877 & 5.5 & 0.0 \\
\hline $14 \mathrm{H}-2,0-5$ & 124.40 & 6,169 & 33,928 & 5.5 & 0.0 \\
\hline $15 \mathrm{H}-2,0-5$ & 133.90 & 5,794 & 37,081 & 6.4 & 0.0 \\
\hline $16 \mathrm{H}-2,0-5$ & 143.40 & 5,301 & 38,166 & 7.2 & 0.0 \\
\hline $17 \mathrm{H}-2,0-5$ & 152.90 & 5,121 & 34,820 & 6.8 & 0.0 \\
\hline $18 \mathrm{H}-2,0-5$ & 162.40 & 4,988 & 38,405 & 7.7 & 0.0 \\
\hline $19 \mathrm{H}-2,0-5$ & 171.90 & 4,452 & 31,162 & 7.0 & 0.0 \\
\hline $20 \mathrm{H}-2,0-5$ & 181.41 & 4,422 & 37,589 & 8.5 & 0.0 \\
\hline $21 \mathrm{H}-2,0-5$ & 190.90 & 4,780 & 31,545 & 6.6 & 0.0 \\
\hline $22 \mathrm{H}-2,0-5$ & 200.40 & 3,216 & 34,406 & 10.7 & 0.0 \\
\hline $23 \mathrm{H}-2,0-5$ & 209.96 & 3,559 & 39,501 & 11.1 & 0.0 \\
\hline $24 \mathrm{H}-2,0-5$ & 219.39 & 3,601 & 44,289 & 12.3 & 0.0 \\
\hline $25 \mathrm{H}-2,0-5$ & 228.90 & 3,435 & 46,032 & 13.4 & 0.5 \\
\hline $26 \mathrm{H}-2,0-5$ & 238.38 & 3,280 & 25,586 & 7.8 & 0.0 \\
\hline $27 \mathrm{H}-2,0-5$ & 247.87 & 2,826 & 39,562 & 14.0 & 0.0 \\
\hline $28 \mathrm{H}-2,0-5$ & 257.40 & 3,224 & 36,433 & 11.3 & 0.0 \\
\hline $29 \mathrm{H}-2,0-5$ & 266.92 & 2,698 & 27,249 & 10.1 & 0.0 \\
\hline $30 \mathrm{H}-2,0-5$ & 274.88 & 2,789 & 30,401 & 10.9 & 0.0 \\
\hline
\end{tabular}


Table T22. Bulk sedimentary carbon and nitrogen, Hole U1305A.

\begin{tabular}{|c|c|c|c|c|c|c|c|}
\hline \multirow{2}{*}{$\begin{array}{l}\text { Core, section, } \\
\text { interval }(\mathrm{cm})\end{array}$} & \multirow{2}{*}{$\begin{array}{l}\text { Depth } \\
\text { (mbsf) }\end{array}$} & \multicolumn{4}{|c|}{ Carbon (wt\%) } & \multirow{2}{*}{$\begin{array}{c}\text { Nitrogen } \\
(w t \%)\end{array}$} & \multirow{2}{*}{$\begin{array}{c}\text { Organic } \\
\mathrm{C} / \mathrm{N}\end{array}$} \\
\hline & & Inorganic & $\mathrm{CaCO}_{3}$ & Total & Organic & & \\
\hline \multicolumn{8}{|l|}{ 303-U1305A- } \\
\hline $1 \mathrm{H}-1,133-134$ & 1.33 & 1.58 & 13.12 & 1.98 & 0.40 & 0.06 & 7.29 \\
\hline $1 \mathrm{H}-6,3-4$ & 7.53 & 0.60 & 5.01 & 0.80 & 0.20 & 0.05 & 4.12 \\
\hline $2 \mathrm{H}-1,133-134$ & 10.23 & 2.23 & 18.60 & 2.76 & 0.53 & 0.06 & 9.60 \\
\hline $2 \mathrm{H}-6,3-4$ & 16.43 & 0.35 & 2.88 & 0.68 & 0.33 & 0.06 & 5.43 \\
\hline $3 \mathrm{H}-1,133-134$ & 19.73 & 2.90 & 24.17 & 3.26 & 0.36 & 0.03 & 11.87 \\
\hline $3 \mathrm{H}-6,3-4$ & 25.93 & 0.26 & 2.13 & 0.38 & 0.12 & 0.00 & \\
\hline $4 \mathrm{H}-1,133-134$ & 29.23 & 0.69 & 5.71 & 1.00 & 0.31 & 0.05 & 5.75 \\
\hline $4 \mathrm{H}-6,2-4$ & 35.42 & 1.06 & 8.83 & 1.43 & 0.37 & 0.06 & 6.59 \\
\hline $5 \mathrm{H}-1,133-134$ & 38.73 & 1.96 & 16.31 & 2.30 & 0.34 & 0.05 & 6.80 \\
\hline $5 \mathrm{H}-6,3-4$ & 44.93 & 0.98 & 8.13 & 1.29 & 0.31 & 0.06 & 4.83 \\
\hline $6 \mathrm{H}-1,133-134$ & 48.23 & 2.34 & 19.53 & 2.59 & 0.25 & 0.03 & 7.64 \\
\hline $6 \mathrm{H}-6,3-4$ & 54.43 & 2.53 & 21.11 & 2.79 & 0.26 & 0.04 & 6.59 \\
\hline $7 \mathrm{H}-1,133-134$ & 57.73 & 2.57 & 21.39 & 3.00 & 0.43 & 0.04 & 9.96 \\
\hline $7 \mathrm{H}-6,3-4$ & 63.93 & 2.72 & 22.65 & 3.24 & 0.52 & 0.05 & 11.39 \\
\hline $8 \mathrm{H}-1,133-134$ & 67.23 & 0.63 & 5.24 & 0.85 & 0.22 & 0.06 & 3.97 \\
\hline $8 \mathrm{H}-6,3-4$ & 73.43 & 1.58 & 13.20 & 2.10 & 0.52 & 0.07 & 7.65 \\
\hline $9 \mathrm{H}-1,133-134$ & 76.73 & 1.53 & 12.76 & 2.06 & 0.53 & 0.09 & 6.07 \\
\hline $9 \mathrm{H}-6,3-4$ & 82.93 & 3.40 & 28.32 & 3.94 & 0.54 & 0.05 & 11.42 \\
\hline $10 \mathrm{H}-1,144-145$ & 86.34 & 0.80 & 6.66 & 1.07 & 0.27 & 0.05 & 5.01 \\
\hline $10 \mathrm{H}-6,0-1$ & 92.40 & 1.14 & 9.49 & 1.33 & 0.19 & 0.05 & 4.05 \\
\hline $11 \mathrm{H}-1,149-150$ & 95.89 & 0.50 & 4.20 & 0.69 & 0.19 & 0.07 & 2.65 \\
\hline $11 \mathrm{H}-6,3-4$ & 101.93 & 2.11 & 17.57 & 2.64 & 0.53 & 0.06 & 9.60 \\
\hline $12 \mathrm{H}-1,147-148$ & 105.37 & 1.58 & 13.15 & 2.04 & 0.46 & 0.06 & 7.85 \\
\hline $12 \mathrm{H}-5,1-2$ & 109.91 & 3.92 & 32.67 & 4.73 & 0.81 & 0.07 & 11.01 \\
\hline $13 \mathrm{H}-1,144-145$ & 114.84 & 0.30 & 2.46 & 0.44 & 0.14 & 0.02 & 6.37 \\
\hline $13 \mathrm{H}-6,1-2$ & 120.91 & 1.91 & 15.95 & 2.18 & 0.27 & 0.06 & 4.29 \\
\hline $14 \mathrm{H}-1,149-150$ & 124.39 & 0.13 & 1.10 & 0.25 & 0.12 & 0.03 & 4.08 \\
\hline $14 \mathrm{H}-6,1-2$ & 130.41 & 0.16 & 1.31 & 0.35 & 0.19 & 0.10 & 1.79 \\
\hline $15 \mathrm{H}-1,133-134$ & 133.73 & 0.84 & 7.03 & 1.09 & 0.25 & 0.06 & 4.44 \\
\hline $15 \mathrm{H}-6,3-4$ & 139.93 & 0.42 & 3.49 & 0.78 & 0.36 & 0.10 & 3.51 \\
\hline $16 \mathrm{H}-1,133-134$ & 143.23 & 0.41 & 3.43 & 0.70 & 0.29 & 0.07 & 3.96 \\
\hline $17 \mathrm{H}-1,133-134$ & 152.73 & 1.87 & 15.55 & 2.31 & 0.44 & 0.09 & 4.83 \\
\hline $17 \mathrm{H}-6,3-4$ & 158.93 & 0.79 & 6.58 & 1.30 & 0.51 & 0.12 & 4.46 \\
\hline $18 \mathrm{H}-1,133-134$ & 162.23 & 5.88 & 48.98 & 6.49 & 0.61 & 0.03 & 18.80 \\
\hline $18 \mathrm{H}-7,3-4$ & 169.96 & 5.19 & 43.22 & 5.84 & 0.65 & 0.05 & 12.85 \\
\hline $19 \mathrm{H}-1,133-134$ & 171.73 & 1.19 & 9.92 & 1.66 & 0.47 & 0.12 & 3.96 \\
\hline $19 \mathrm{H}-6,3-4$ & 177.95 & 0.77 & 6.42 & 1.22 & 0.45 & 0.11 & 4.07 \\
\hline $20 \mathrm{H}-1,133-134$ & 181.23 & 1.03 & 8.55 & 1.26 & 0.23 & 0.07 & 3.38 \\
\hline $20 \mathrm{H}-6,3-4$ & 187.54 & 1.37 & 11.38 & 1.62 & 0.25 & 0.05 & 5.28 \\
\hline $21 \mathrm{H}-1,133-134$ & 190.73 & 0.11 & 0.93 & 0.32 & 0.21 & 0.05 & 4.36 \\
\hline $21 \mathrm{H}-6,3-4$ & 196.99 & 0.13 & 1.06 & 0.33 & 0.20 & 0.10 & 2.00 \\
\hline $22 \mathrm{H}-1,133-134$ & 200.23 & 0.20 & 1.67 & 0.34 & 0.14 & 0.04 & 3.87 \\
\hline $22 \mathrm{H}-6,3-4$ & 206.33 & 0.64 & 5.35 & 1.21 & 0.57 & 0.14 & 4.13 \\
\hline $23 \mathrm{H}-1,151-152$ & 209.91 & 1.48 & 12.35 & 1.97 & 0.49 & 0.07 & 6.57 \\
\hline $23 \mathrm{H}-6,1-2$ & 216.06 & 1.80 & 14.99 & 2.21 & 0.41 & 0.10 & 3.97 \\
\hline $24 \mathrm{H}-1,142-143$ & 219.32 & 1.24 & 10.31 & 1.52 & 0.28 & 0.05 & 5.87 \\
\hline $24 \mathrm{H}-6,2-3$ & 225.33 & 3.39 & 28.21 & 3.70 & 0.31 & 0.05 & 6.53 \\
\hline $25 \mathrm{H}-1,143-144$ & 228.83 & 2.65 & 22.05 & 2.91 & 0.26 & 0.06 & 4.31 \\
\hline $25 \mathrm{H}-6,0-1$ & 234.87 & 1.80 & 14.98 & 2.11 & 0.31 & 0.04 & 6.99 \\
\hline $26 \mathrm{H}-1,145-146$ & 238.35 & 0.87 & 7.23 & 1.07 & 0.20 & 0.05 & 3.67 \\
\hline $26 \mathrm{H}-6,0-1$ & 244.32 & 0.11 & 0.88 & 0.31 & 0.20 & 0.07 & 2.96 \\
\hline $27 \mathrm{H}-1,144-145$ & 247.84 & 1.34 & 11.18 & 1.73 & 0.39 & 0.10 & 3.92 \\
\hline $27 \mathrm{H}-6,0-1$ & 253.74 & 0.30 & 2.51 & 0.47 & 0.17 & 0.06 & 2.96 \\
\hline $28 \mathrm{H}-1,133-134$ & 257.23 & 0.34 & 2.82 & 0.61 & 0.27 & 0.06 & 4.79 \\
\hline $28 \mathrm{H}-6,3-4$ & 263.41 & 0.76 & 6.33 & 1.03 & 0.27 & 0.07 & 3.66 \\
\hline $29 \mathrm{H}-1,143-144$ & 266.83 & 0.76 & 6.34 & 1.10 & 0.34 & 0.07 & 4.67 \\
\hline $29 \mathrm{H}-6,3-4$ & 272.83 & 3.71 & 30.91 & 4.35 & 0.64 & 0.10 & 6.61 \\
\hline $30 \mathrm{H}-1,143-144$ & 274.83 & 1.74 & 14.52 & 2.11 & 0.37 & 0.11 & 3.50 \\
\hline
\end{tabular}


Table T23. Interstitial water geochemistry, Hole U1305A.

\begin{tabular}{|c|c|c|c|c|c|c|c|c|c|c|c|c|c|c|c|c|c|c|c|}
\hline \multirow{2}{*}{$\begin{array}{l}\text { Core, section, } \\
\text { interval }(\mathrm{cm})\end{array}$} & \multirow{2}{*}{$\begin{array}{l}\text { Depth } \\
\text { (mbsf) }\end{array}$} & \multicolumn{2}{|c|}{ Anions (mM) } & \multirow[b]{2}{*}{$\mathrm{pH}$} & \multirow{2}{*}{$\begin{array}{l}\text { Alkalinity } \\
(\mathrm{mM})\end{array}$} & \multirow{2}{*}{$\begin{array}{l}\text { Salinity } \\
(\mathrm{g} / \mathrm{kg})\end{array}$} & \multicolumn{4}{|c|}{ Major cations (mM) } & \multicolumn{8}{|c|}{ Minor and trace constituents $(\mu \mathrm{M})$} & \multirow{2}{*}{$\begin{array}{c}\mathrm{Sr} / \mathrm{Ca} \\
(\mu \mathrm{M} / \mathrm{mM})\end{array}$} \\
\hline & & $\mathrm{SO}_{4}{ }^{2-}$ & $\mathrm{Cl}^{-}$ & & & & $\mathrm{Na}^{+}$ & $\mathrm{K}^{+}$ & $\mathrm{Mg}^{2+}$ & $\mathrm{Ca}^{2+}$ & $\mathrm{NH}_{4}^{+}$ & $B$ & $\mathrm{Ba}^{2+}$ & $\mathrm{Fe}^{2+}$ & $\mathrm{Li}^{+}$ & $\mathrm{Mn}^{2+}$ & $\mathrm{H}_{4} \mathrm{SiO}_{4}$ & $\mathrm{Sr}^{2+}$ & \\
\hline \multicolumn{20}{|l|}{ 303-U1305A- } \\
\hline $1 \mathrm{H}-1,145-150$ & 1.45 & 21.52 & 560 & 7.37 & 9.12 & 36 & 481 & 11.66 & 51.89 & 7.81 & 658 & 525 & 0.3 & 9.2 & 18.9 & 23.5 & 720.9 & 79.2 & 10.1 \\
\hline $2 \mathrm{H}-1,145-150$ & 10.35 & 17.22 & 563 & 7.27 & 10.81 & 35 & 481 & 11.91 & 50.68 & 6.92 & 622 & 551 & 0.3 & 15.7 & 17.2 & 31.5 & 634.3 & 73.1 & 10.6 \\
\hline $3 \mathrm{H}-1,145-150$ & 19.85 & 13.38 & 565 & 7.31 & 12.25 & 35 & 482 & 11.62 & 49.03 & 6.07 & 676 & 541 & 0.5 & 15.8 & 15.3 & 21.6 & 714.9 & 71.6 & 11.8 \\
\hline $4 \mathrm{H}-1,145-150$ & 29.35 & 8.81 & 567 & 7.46 & 14.95 & 35 & 484 & 11.25 & 46.53 & 5.36 & 861 & 552 & 0.6 & 5.2 & 14.0 & 32.3 & 657.3 & 67.1 & 12.5 \\
\hline $5 \mathrm{H}-1,145-150$ & 38.85 & 4.84 & 564 & 7.37 & 16.57 & 35 & 481 & 10.76 & 45.16 & 4.15 & 1001 & 538 & 1.0 & 9.6 & 14.0 & 14.5 & 742.3 & 66.7 & 16.0 \\
\hline $6 \mathrm{H}-1,145-150$ & 48.35 & 1.49 & 565 & 7.46 & 18.48 & 34 & 481 & 10.35 & 44.21 & 3.21 & 1086 & 518 & 3.3 & 13.3 & 12.3 & 10.6 & 716.0 & 69.9 & 21.8 \\
\hline $7 \mathrm{H}-1,145-150$ & 57.85 & 0.07 & 565 & 7.38 & 18.85 & 34 & 481 & 9.75 & 43.86 & 2.58 & 1328 & 561 & 16.6 & 17.9 & 11.2 & 5.5 & 725.4 & 70.0 & 27.1 \\
\hline $10 \mathrm{H}-1,145-150$ & 86.35 & 0.05 & 566 & 7.62 & 17.55 & 34 & 482 & 9.18 & 42.96 & 3.44 & 1289 & 517 & 15.8 & 19.8 & 13.6 & 5.2 & 728.9 & 72.9 & 21.2 \\
\hline $13 \mathrm{H}-1,145-150$ & 114.85 & 0.36 & 567 & 7.79 & 16.09 & 33 & 484 & 9.02 & 41.19 & 4.09 & 1584 & 448 & 18.2 & 7.2 & 15.1 & 4.3 & 653.2 & 74.2 & 18.1 \\
\hline $16 \mathrm{H}-1,145-150$ & 143.35 & 0.00 & 565 & 7.57 & 15.46 & 33 & 482 & 8.13 & 40.49 & 4.81 & 1642 & 499 & 11.5 & 17.1 & 18.8 & 7.6 & 759.7 & 75.8 & 15.8 \\
\hline $19 \mathrm{H}-1,145-150$ & 171.85 & 0.18 & 569 & 7.48 & 13.69 & 34 & 487 & 7.91 & 38.47 & 5.61 & 2085 & 507 & 9.9 & 3.4 & 23.2 & 8.2 & 797.3 & 78.5 & 14.0 \\
\hline $22 \mathrm{H}-1,145-150$ & 200.35 & 0.00 & 566 & 7.58 & 12.50 & 33 & 486 & 7.53 & 35.58 & 7.07 & 2252 & 435 & 12.3 & 5.7 & 26.1 & 8.8 & 797.3 & 84.6 & 12.0 \\
\hline $25 \mathrm{H}-1,145-150$ & 228.85 & 0.10 & 571 & 7.43 & 7.31 & 33 & 492 & 7.34 & 32.19 & 7.14 & 2477 & 442 & 13.2 & 10.0 & 30.0 & 6.2 & 840.0 & 85.0 & 11.9 \\
\hline $28 \mathrm{H}-1,145-150$ & 257.35 & 0.30 & 573 & 7.91 & 6.00 & 33 & 494 & 7.04 & 29.66 & 9.41 & 2535 & 411 & 14.3 & & 30.5 & 6.9 & 589.2 & 91.8 & 9.8 \\
\hline
\end{tabular}

